This item was submitted to Loughborough's Research Repository by the author.

Items in Figshare are protected by copyright, with all rights reserved, unless otherwise indicated.

Justice, order and anarchy: the international political theory of Pierre-Joseph Proudhon (1809-1865)

PLEASE CITE THE PUBLISHED VERSION

PUBLISHER

(c) W.A.L. Prichard

LICENCE

CC BY-NC-ND 4.0

REPOSITORY RECORD

Prichard, Alex. 2019. "Justice, Order and Anarchy: The International Political Theory of Pierre-joseph Proudhon (1809-1865)”. figshare. https://hdl.handle.net/2134/12162. 


\section{Loughborough University}

This item was submitted to Loughborough University as a PhD thesis by the author and is made available in the Institutional Repository

(https://dspace.lboro.ac.uk/) under the following Creative Commons Licence conditions.

\section{cc) creative}

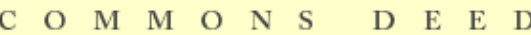

Attribution-NonCommercial-NoDerivs 2.5

You are free:

- to copy, distribute, display, and perform the work

Under the following conditions:

Attribution. You must attribute the work in the manner specified by the author or licensor.

Noncommercial. You may not use this work for commercial purposes.

No Derivative Works. You may not alter, transform, or build upon this work.

- For any reuse or distribution, you must make clear to others the license terms of this work.

- Any of these conditions can be waived if you get permission from the copyright holder.

Your fair use and other rights are in no way affected by the above.

This is a human-readable summary of the Leqal Code (the full license).

Disclaimer 민

For the full text of this licence, please go to: http://creativecommons.org/licenses/by-nc-nd/2.5/ 
For

Social Justice 


\title{
Justice, Order and Anarchy: The International Political Theory Of Pierre-Joseph Proudhon (1809-1865)
}

\author{
W. A. L. Prichard
}

Doctoral Thesis Submitted in Partial Fulfilment of the Requirements for the Award of Doctor of Philosophy of Loughborough University

\author{
$3^{\text {rd }}$ April 2008
}

(C) by W. A. L. Prichard, 2008 


\title{
The Lisbon Earthquake
}

\author{
Voltaire \\ (1755) \\ D'inutiles douleurs éternel entretien! \\ Philosophes trompés qui criez: "Tout est Bien" \\ Accourez, contemplez ces ruines affereuses, \\ Ces débris, ces lambeaux, ces cendres malheureuses, \\ Ces femmes, ces enfants l'un sur l'autre entassés, \\ Sous ces marbres rompus ces members dispersés; \\ Direz-vous, C'est l'effet des éternelles lois \\ Qui d'un Dieu libre et bon nécessitent le choix? \\ Non, ne présentez plus à mon coeur agité \\ Ces immuables lois de la necéssité, \\ Cette chaîne des corps, des esprits, et des mondes \\ $O$ rêves de savants! O chimères profondes! \\ Dieu tient en main la chaîne, et n'est point enchaîné; \\ Par son choix bienfaisant tout est déterminé, \\ Il est libre, il est juste, il n'est point implacable. \\ Pourquoi donc suffrons-nous sous un maitre équitable?
}


This thesis provides a contextualised exegesis and re-evaluation of the anarchist PierreJoseph Proudhon's writings on war and peace. The thesis has two claims to originality. The first lies in shedding new light on Proudhon's voluminous writings on international politics. These texts have been relatively marginalised in the broader secondary literature on Proudhon's thinking, and the thesis seeks to correct this important lacuna. In International Relations (IR), the academic discipline to which this thesis will make its most obvious original contribution, Proudhon's writings on war and peace have been almost completely ignored. By providing an anarchist approach to world politics, the thesis will also contribute to IR's historiographical and critical theoretical literature. The second claim to originality lies in using these writings and the context from which they emerged to tell a story about the evolution of the nineteenth century, the origins of the twentieth century and provide possible ways of thinking beyond the twenty first.

The thesis employs a contextualist methodology that works in four ways. First, I have contextualised Proudhon's thought geo-politically, in relation to the dynamics of the balance of power in nineteenth-century Europe. Secondly, I have sought to understand Proudhon's ideas against the backdrop of the evolution of the French nation state in the mid to late nineteenth century. Third, I have shown how Proudhon's thought emerges out of the dominant intellectual currents of his day - ideas that range from the inspiration for the activism of Fourierist and Saint-Simonian feminists, to the epochal influence of Rousseau and Kant. Finally, I argue that Proudhon's thinking on world politics needs to be understood in relation to the evolution of his own thinking after Napoleon III's coup d'état of the $2^{\text {nd }}$ of December 1851. I will show that Proudhon's mature anarchism, his mutualist federalism, was an engaged response to each of these social and intellectual contexts. I will argue that his critiques of these processes, and their intellectual champions, have been given an added poignancy given that he campaigned in large part against those very processes that culminated in two world wars.

Keywords: Anarchism, Balance of Power, Federalism, International Relations, International Political Theory, Pierre-Joseph Proudhon, Political Theory, Mutualism, Nineteenth-Century France 


\section{Preface}

"Most young men and women at the century's end grow up in a sort of permanent present lacking any organic relation to the public past of the times they live in."

"Our schools of rationality balk at having their histories written,

Eric Hobsbawm which is no doubt significant."

Michel Foucault

During the course of writing up my research Masters in International Relations (IR) theory at the University of Wollongong, I discovered that Proudhon had written a fair bit on international politics. But despite a plethora of post-statists in modern IR and political theory, most of whom called themselves postmodern or critical, no one seemed to have read any anarchism, let alone Proudhon's work on international politics. Nor had I for that matter. So this thesis effectively began life as a hunch, in late-1999. I assumed, somewhat naively, that anything Proudhon had to say about world politics would undoubtedly be able to contribute to contemporary postmodern, critical and postsovereign social theory, and would obviously resonate with the concerns and aspirations of the anti-capitalist carnival in Seattle that July. I also hoped to contribute something to IR theory, though I had a fair idea that it would not be gladly received.

This utopianism turned into giddy excitement when I took delivery of the two volumes of Proudhon's La Guerre et la Paix. I then developed a self-assured arrogance when I was offered a (self-funded) place on the PhD programme at the Department of International Politics, at Aberystwyth. Being from North Wales, I felt like I was going home, and I also thought I was radical. But the PhD ultimately became too much of a burden, and thankfully I did not have to bear it alone. Generous financial support and guidance from friends, colleagues and family has helped me through. I would not have made it without them. I have had superb supervision and have infuriated so many people with my defence of Proudhon, that innumerable bad ideas thankfully never made it into this final draft. What remains can only be described as the emergent, irreducible product of collective effort. As a result I owe a profound debt of thanks, and a comparable financial debt, to many. 
I began work on the thesis in 2001 having spent the previous nine months working as a chef in a trendy West London restaurant. Despite an ability to work all hours and a stubbornness born of desperation, I was utterly unprepared for the rude awakening I received on arrival at Aberystwyth. I had no idea what a $\mathrm{PhD}$ was and despite my first supervisor's hope that I had thick skin, and my own cocksure riposte that chefs have calloused hands, I had no idea what he meant. It turned out that I had neither the requisite skills nor the temperament for academic writing - but, thankfully, I really did have thicker skin than most.

The problem was, I guess, that I did not have a 'coherent' project. This is a problem most $\mathrm{PhD}$ students face and I claim no special status. Moreover, most students construct the shape of the $\mathrm{PhD}$ after it's been substantially written. But it's rare that none of your peers and seniors have any idea what it is you're going to write about and most are actively hostile towards it. "Why Proudhon?” people would ask, isn’t he: “contradictory”, "paradoxical”, “dead"? "What? you mean you know nothing about his work on international politics!?” ('either’ should always have followed here, but rarely did). “Isn’t he a utopian who thinks man is inherently good!?" "Surely an anarchist can have nothing to say about IR - IR is about states?” "Perhaps history has consigned him to the dustbin with good reason?" and finally, it all boiled down to the question: "You don’t want to write a thesis on Proudhon do you?!” the assumption being that the history of ideas was somehow less important than IR theory, or that it had little bearing on the main concerns of the discipline. It goes without saying that without pinpointing someone's ignorance, academic careers would be few and far between. For others, ignorance can be the most formidable barrier to starting one.

After a difficult year I failed to produce the requisite work. I had failed to adjust to the demands of a modern $\mathrm{PhD}$ because I was working 15 hours a week as a chef. I also had 12 hours a week of research training (useless platitudes to funding bodies trying to weed out critical thinking) and taught four hours of seminars a week as well. Independent research of a type I was not acquainted with was almost impossible. I was encouraged to 
take a second Masters. This time it would be a taught Masters, so that I learnt the right things and so that I had a better frame of reference within which to locate the thesis - the assumption remained that I would contribute to contemporary problems in IR theory. It also gave me a year to practice my writing, secure funding and rejoin my $\mathrm{PhD}$ buddies in twelve months time. I was not so fortunate.

I passed the Masters degree well - even getting a distinction for my dissertation again but I was forced to accept that I had not jumped through the hoops well enough. Due to a lack of funding, for the duration of the year I had to work 20+ hours a week in a hot kitchen under precarious financial conditions. Sadly I was not alone in this experience, nor, I should imagine, will I be the last to face it. Thankfully, I secured a generous grant to cover fees and maintenance, from the Thomson Foundation, which was paid in exchange for research work for the Welsh TV station S4C. This was greatfully received.

I worked 16 hours a week compiling reports on the nature of Welsh-language broadcasting. Little by little I became socialised into the role of an anarchist Mary Whitehouse (imagine such a thing!). This became a problem in the second year of the restarted PhD when I also took on a position of warden in a hall of residence. My highly developed left-conservative attitudes clashed with childishness and sleep deprivation and ensured that along with my significant PhD problems and 16 hours of TV a week, 2004-5 went down as one of the worst years of my life.

I had been looking into ways of getting out of Aberystwyth for two years when, by pure chance, I received an email from the Research on Anarchism list. The Department of Politics, IR and European Studies at Loughborough University was advertising a fully funded $\mathrm{PhD}$ place for someone to work on anarchism from within IR or politics. Imagine my surprise! With Aberystwyth still unable to offer me very much of anything at all, I left as soon as I could. With five years of graduate education behind me I moved to Loughborough and started the first year of my $\mathrm{PhD}$ for the third time. A formal expression of thanks to Loughborough University hardly seems sufficient for what was a 
life-changing stroke of luck. Still, the generous Halliwell Scholarship and the seemingly endless conference and research funding was gratefully received.

On arrival at Loughborough everything changed almost over night; not least because for the first time I had time and money. In Ruth Kinna and Dave Berry I also had two supervisors who cared about my subject, were generous with their time and fun to be with. They also had enough background knowledge to let me get on with it. But it soon became patently obvious that my main problem was that an undergraduate degree and two Masters degrees in IR theory were utterly useless in preparing me for the thesis I eventually came to write. IR routinely bemoans its isolation from the rest of the social sciences and its failure to convince other disciplines of its merits. It took perhaps three months for me to see why. On the whole, IR theory, arguably the mainstay of the discipline, is, generally speaking, poor.

I think it was in one of my first supervisory meetings at Loughborough that I pointed to the work of Quentin Skinner. Finally I had a vocabulary and set of tools with which to explain both IR and Political theory's quandary vis-à-vis anarchism, and the nearuniversal ignorance of Proudhon's thought in particular. What I finally felt confident in arguing was that IR theory is itself built on an almost wholesale misunderstanding of the ideas of past political theorists - ideas which have been utterly deformed in the interests of twentieth century Western capitalist and geo-political interests.

For helping me beyond the parochialism of IR theory and the tepid waters of political theory, and into the gentle stream that is the history of ideas, I owe a significant intellectual debt to Ruth Kinna. Dave Berry has provided an important historical corrective to my theorist's penchant for verbosity and obfuscating nonsense. His knowledge of modern French history and politics has also been invaluable. Both Ruth and Dave were a constant source of inspiration and encouragement, and my sincerest gratitude to both cannot be adequately expressed here. 
I would also like to thank my progression panel at Loughborough, Paul Byrne, Oliver Daddow and Moya Lloyd, for their insightful and helpful comments on each chapter of the thesis. I would also like to thank Rob Dover for his comments and suggestions and Michael Mulligan for our engaging pub discussions. I would also like to wish my new anarcho-PhD companions at Loughborough, Saku Pinta, Sureyyya Evren and Matt Wilson, all the best, and look forward to reading the product of their research. Having like-minded peers to drink and chat with is something most take for granted. In anarchist academic circles it is the exception and I am grateful to Ruth and Dave for building such a strong community.

Andrew Linklater took the initial gamble on this $\mathrm{PhD}$ by encouraging me to take it on in the summer of 2001. He remained with the project until I left Aberystwyth in 2005, and is still a source of encouragement and support. If you listen carefully, echoes of his pioneering work can be heard in the pages that follow. I also want to thank Jan Selby for his patient support during my second Masters degree and for supervising the thesis for the first eighteen months of its second attempt. Without his intellectual support, and the practical help of reading successive rather poor chapters, I would have lacked the confidence to convince anyone else of the merits of Proudhon's thinking, and would have given up with two Masters degrees in a subject area that would have been of little use outside the university. I would also like to thank Peter Jackson who took over from Jan for a semester before I left for Loughborough, particularly for putting me onto Frank E. Manuel's work. I would also like to thank Roger Price for pointing me to the most recent French literature during my last years at Aberystwyth. Thanks also to Richard Wyn Jones and Mike Williams for their valiant attempts to rescue me from having to undertake the second Masters degree and for Richard's advice that, in the absence of other options, I should take it on. I would also like to thank Steve Regler and Andrew Wells at the University of Wollongong, New South Wales, for their earliest encouragement and advice, and Rajani Kanth for his unstinting support through all the trials which followed.

I also made life-long friends at Aberystwyth and had some excellent advice, support and direction from them all. I owe a profound debt of gratitude to Adriana Sinclair for her 
support through very difficult years. I also need to thank her parents, Lukman and Latimah for having faith in my project. I would also like to thank Kerry Crusoe for her support. Thanks to Neil Pankhurst for his recent aid. Thanks also to all my fellow chefs from 1999 to 2004 - especially Matt Dafforne - all of whom remind me that there is a real world beyond academia, and it's hot and stressful. I also owe a significant debt to Gerry Hughes whose depth of scorn for critical theorists is matched only by his generosity. I also need to thank Matt and Gerry, both exemplary historians, for their insistence, over far too much beer, that explaining past ideas without context results in fiction, and that theory without history is useless. It wasn't until I read Skinner that I fully understood what they meant. I also owe a significant intellectual debt to Milja Kurki, without whose direction through the literature on Critical Realism I would probably still be stuck in some postmodern mire.

I also owe a debt of gratitude to the many networks of anarchists and radical scholars who made the otherwise grindingly solitary endeavour of writing a $\mathrm{PhD}$ in an unpopular area so much more enjoyable and exciting. In particular, I would like to thank the contributors to Anarchist Academics, RA Forum, NASPIR and, of course, all the good friends I've made through the Anarchist Studies Network. Thanks are also due to Edward Castleton for his personal transcriptions of Proudhon's handwritten notes and annotations. The Société Proudhon deserves our warmest support for its tireless work in keeping the memory of Proudhon alive. My only regret through all of this has been my inability to be more active in my politics. But I hope the above provides part of the excuse, at least.

I would like to thank my parents, Mark and Susanne, and the rest of my family for their enduring support. And finally, my partner Ana Juncos has been a kind and loving companion, who tolerated none of my 'precious me' moments, and pushed me across the finishing line. Now this is over, we finally have the time to get on with our lives together. 


\section{Table of Contents}

Abstract vi vi vi vis

Preface vii

$\begin{array}{ll}\text { Introduction } & 1\end{array}$

Part 1: Context

Chapter 1: Nationalism and the Nineteenth Century European Balance of Power 28

Chapter 2: The Change and Entrenchment of Étatisme in Nineteenth-Century France 65

Chapter 3: Providence, Imperialism and the Evolution of European Political Thought 106

Part 2: Exegesis

Chapter 4: Justice and Order 156

$\begin{array}{ll}\text { Chapter 5: War and Change } & 195\end{array}$

Chapter 6: Justice and Order in Anarchy 238

$\begin{array}{ll}\text { Conclusion } & 277\end{array}$

$\begin{array}{lr}\text { Bibliography } & 298\end{array}$ 


\section{Introduction}

"Proudhon, a democrat without illusions"1

7 This thesis provides a contextualised exegesis and re-evaluation of the anarchist Pierre-Joseph Proudhon's writings on war and peace. The thesis has two claims to originality. The first lies in shedding new light on Proudhon's voluminous writings on international politics. These texts have been relatively marginalised in the broader secondary literature on Proudhon's thinking, and the thesis seeks to correct this important lacuna. In International Relations (IR), the academic discipline to which this thesis will make its most obvious original contribution, Proudhon's writings on war and peace have been almost completely ignored. By contributing an anarchist approach to world politics the thesis will also contribute to IR's historiographical and critical theoretical literature. The second claim to originality lies in using these writings and the context from which they emerged to tell a story of the evolution of the nineteenth century, the origins of the twentieth century and provide possible ways of thinking beyond the twenty first.

The thesis employs a contextualist methodology that works in four ways. First, I have contextualised Proudhon's thought geo-politically, in relation to the dynamics of the balance of power in nineteenth-century Europe. Secondly, I have sought to understand Proudhon's ideas against the backdrop of the evolution of the French nation state in the mid to late nineteenth century. Third, I have shown how Proudhon's thought emerges out of the dominant intellectual currents of his day - ideas that range from the inspiration for the activism of Fourierist and Saint-Simonian feminists, to the epochal influence of Rousseau and Kant. Finally, I argue that Proudhon's thinking on world politics needs to be understood in relation to the evolution of his own thinking after Napoleon III's coup d'état of the $2^{\text {nd }}$ of December 1851. I will show that Proudhon's mature anarchism, his mutualist federalism, was an engaged response to each of these social and intellectual contexts. I will argue that his critiques of these processes, and their intellectual

\footnotetext{
${ }^{1}$ Taylor [1995b], p. 162.
} 
champions, now have an added poignancy given that he campaigned in large part against those very processes that culminated in two world wars.

As mentioned, presenting the thesis in this way contributes to two broad literatures in IR. The first literature seeks a more sophisticated historiography of the canon of the discipline. $^{2}$ Those writing in this area have shown that IR has been constructed around an overly narrow canon of thought. Moreover, analysis of past thinkers leans heavily on established myth rather than contextualised sensitivity to the intentions and audience of these canonical figures. However, the perpetuation of these myths serves the broader purpose of sustaining contemporary mainstream conceptions of the discipline's past, contemporary purpose and political value. The second literature to which this thesis will contribute is the more critical approaches to IR theory. ${ }^{3}$ The main characteristic of this literature is the rise of new, post-statist and non-reductionist approaches to world politics. Theorists in this area foreground the emancipatory potential within contemporary historical trajectories, social movements and critical philosophies. The thesis' two main aims of explaining Proudhon's anarchist approach to world politics, and understanding this within broader intellectual and political history, will thus contribute directly to these two literatures.

In this introduction I will begin by providing a review of the secondary literature on this aspect of Proudhon's thought. What I will show is that where it is engaged with at all it is near-universally negative in its evaluation. I divide this analysis between five broad literatures: IR theory, Political theory, the history of political thought, and modern sociology. Then I turn to recent developments in International Political theory. Despite excavating the thought of innumerable other figures in the history of political thought for their ideas about world politics, those working in this area have completely overlooked Proudhon. The reasons for this are complex, but are largely explicable by the negative evaluations of Proudhon's thought in this area. This thesis will demonstrate that these negative evaluations are largely incorrect. This has important implications for how we

\footnotetext{
${ }^{2}$ See, for example, Long and Wilson [1995], Little [1999], Holden [2002], Bell [2003], Ashworth [2006]

${ }^{3}$ A recent special edition of Review of International Studies provides a contemporary summary of critical theory in IR. See Rengger and Thirkell-White [2007].
} 
understand the evolution of IR theory and I return to this historiographical line of argument below.

I will then briefly discuss the handful of lone voices in post-war IR that have called for a return to anarchism for conceptual and analytical insight. Despite making strong cases, the unifying feature of these calls is that none seem familiar with the extensive writings of Proudhon on this subject. However, one of these calls for a turn to the anarchist literature is particularly interesting for this thesis. Andrew Linklater's work in critical IR theory is remarkable in its own right, but also because of the distinct echoes we hear of Proudhon's thought within it.

It is, of course, impossible to substantiate these claims before we have a better idea of what it was Proudhon actually argued. The exegesis of his writings is therefore the central feature of this thesis. However, there are methodological and theoretical hurdles to providing a better account of his thought. In the second part of this introduction I set out my research methodology and highlight some of the methodological flaws in past readings of Proudhon's work on international politics. Once I have opened up the possibility that Proudhon's thought might have been misrepresented and misread, and that the critical methodology used to discover this might also serve the ends of reconstructing a better reading of his texts, I can better-illustrate how I intend to do this. I conclude the introduction by setting out my two key research questions, discuss the core primary literature which makes up the bulk of the research material, and close with a brief chapter outline.

\section{The Academic Secondary Literature}

I begin this review of the IR literature that engages with Proudhon's international political theory with the so-called fathers of the dicipline - Hans Morgenthau and E. H. Carr. Their evaluation of Proudhon's work, penned in the immediate aftermath of the Second World War, was unquestionably negative. Given their critical reviews, and the discipline-defining caricature of pre-Realist 'Idealist' approaches to IR theory, it is 
perhaps unsurprising that Proudhon does not feature in the historiography of the discipline again. My review then moves outwards to political theory, sociology and the history of political thought in order to give a flavour of the extant engagements with Proudhon's thinking there. Here we find that the tenor of critique remains largely the same, if sometimes more sympathetic. I close the review with a brief survey of contemporary International Political theory. The absence of Proudhon's thought within this literature is perhaps a function of the negative readings of Proudhon's thought in all the preceding literatures.

\section{IR Theory}

Writing in the The Times Literary Supplement, soon after the end of the Second World War, E. H. Carr claimed that Proudhon was "one of the first crank financial reformers", an "isolated eccentric" out of touch with his time. ${ }^{4}$ Furthermore, he argued, Proudhon's vision of "a world of independent self-assertive individuals" ${ }^{5}$ was doomed to be subsumed by the forces of modern nationalism and his approach was also full of "self contradictions”. ${ }^{6}$ For example, Carr casts Proudhon as an individualist and suggests that this clashes with his theory of federalism. He thought Proudhon something of a chauvinist, and that this contradicted his critique of everyone else's nationalism. Perhaps most importantly Carr also implied that Proudhon's two-volume La Guerre et la Paix, the central text of this thesis, could be dismissed "as a passing aberration" or a "confusion of thought". It was a "panegyric on war" that included a "disconcerting streak of selfassertive nationalism". ${ }^{7}$ This evaluation doubtless goes some way towards explaining why Carr agreed with J. Selwyn Schapiro that Proudhon was a "progenitor of Hitlerism”. ${ }^{8}$ This is quite a claim, but Schapiro goes even further than this. He argues that Proudhon's followers have in fact mistakenly seen Proudhon as an anarchist; Schapiro claims he was, in fact, a virulent anti-Semite and a "harbinger of Fascism", ${ }^{9}$ an argument

\footnotetext{
${ }^{4}$ Carr [1950], p. 48.

${ }^{5}$ Ibid, p. 55.

${ }^{6}$ ibid, p. 46.

7 ibid, p. 52.

${ }^{8}$ ibid, p. 40.

${ }^{9}$ Schapiro [1946].
} 
that Carr believes he "depicts [...] with skill and plausibility."10 As the thesis will show, both Carr and Schapiro’s accounts of Proudhon's thought are completely inaccurate.

Hans Morgenthau, the second 'father' of IR theory, gives us insight into the prevalence of two further positions on Proudhon's thought in the immediate post-war period. The first is the argument that Proudhon was a liberal individualist and supporter of laissez faire capitalism. Morgenthau believed that Proudhon, like his contemporaries Cobden and Bright, was "convinced that the removal of trade barriers was the only condition for the establishment of permanent harmony among nations, and might even lead to the disappearance of international politics altogether."11 Nineteenth-century nationalism and power politics sounded the death knell of Cobden and Bright's liberal internationalism, as I will discuss in chapters one and two. However, as I will show in chapters one, five and six, this argument is simply not applicable to Proudhon's thought.

But perhaps even more important is Morgenthau's claim that "Proudhon was among the first to glorify the blessings of science in the international field."12 The historical significance of Proudhon's thought in this area was subsequently ignored by all who followed Morgenthau, because for Morgenthau what this actually meant was that Proudhon was thus guilty of a second naïveté - scientism. Morgenthau's position on science in its application to matters of world politics is well known. He argued against neo-Kantian "scientific utopians” who, he argued, believed that if human behaviour could be brought into line with universal reason, the harmony that would emerge would be forceful enough to illustrate the stupidity of the "atavism of power politics". ${ }^{13}$ Proudhon, it is implied, was one of the first to suggest such nonsense, and Morgenthau directs the reader to Proudhon's La Guerre et la Paix in a footnote as evidence of this. Both Carr and Morgenthau were the fathers of Realism as an approach to international relations, and their casting of all who came before them as idealists is perhaps the founding myth of

\footnotetext{
${ }^{10}$ Carr [1950], p. 40.

${ }^{11}$ Morgenthau [1993], p. 35. cf. Morgenthau [1958], p. 244.

12 ibid, p. 42.

13 ibid, p. 41.
} 
academic IR. ${ }^{14}$ For both, neo-Kantian liberalism was the cause of the inter-war crisis and the failure of IR to establish itself as a coherent discipline. Placing Proudhon in this neoKantian tradition was a discursive strategy that is simply not warranted by the evidence. As I will show in chapters three and four, by unpacking Proudhon's critique of Kant, Morgenthau was also simply wrong.

Carr and Morgenthau cannot be held solely responsible for Proudhon's absence from the canon of IR theory, and I have not come across any evidence to suggest that others have repeated their views in print. Nevertheless, their influence in the formation of IR as a post-war academic discipline is incontestable, ${ }^{15}$ and yet it is only very recently that their ideas have begun to be re-examined. Both Carr and Morgenthau cast nearly all who came before them as utopians or idealists. The hegemony of realism in post-war debates about IR theory, particularly its explicit statism, helps explain why Proudhon's thought might be seen to be antithetical to a realist-dominated IR. A return to Proudhon's thought is perhaps only possible now that this hegemony has begun to be eroded by a plethora of critical and post-statist approaches to IR theory. I return to this literature below.

\section{Political Theory, the History of Political Thought}

The political and philosophical literature that engages with Proudhon's thought is not extensive. The only single authored monograph in any language to deal entirely with Proudhon's political theory - to the exclusion of all other aspects of his work - is Alan Ritter's The Political Thought of Pierre-Joseph Proudhon (1969). Ritter uses Proudhon's international political theory, that is to say his later writings on war, peace and justice, to elucidate his political theory. ${ }^{16}$ This is a somewhat amusing from the perspective of IR theory, given that most within IR seem to have routinely done the opposite - that is to say most use the 'domestic' political theory of, for example, Hobbes or Rousseau, to better

\footnotetext{
${ }^{14}$ See Wilson [1998].

${ }^{15}$ cf. Schmidt [1998].

${ }^{16}$ Ritter [1969], p. 26.
} 
understand the snippets of their writings relating to inter-state relations. ${ }^{17}$ Ritter's analysis, while unique in this regard, nevertheless fails for a number of reasons.

Ritter takes what he calls an "analytic approach", ${ }^{18}$ which was until recently the standard approach to the history of ideas. Ritter's work derives the meaning of Proudhon's theory solely from his published writings and from the internal coherence of their central propositions. He divests Proudhon's thought of its historical context and intellectual lineage almost entirely. Ritter argues that Proudhon's thought can be reduced to a first principle assumption of "respect", and sets about assessing various propositions in Proudhon's theory in so far as they are consistent or inconsistent with this first principle assumption.

Ritter concludes that Proudhon's theory of mutualism - the basis of his mature anarchism - "is manifestly ineffective" when considered in relation to the so-called realities of geopolitics. In this respect Ritter echoes the Realism of his academic mentor Stanley Hoffmann, ${ }^{19}$ when he claims that the eternally predatory instincts of states would prey on mutualist communities. He continues that "[t]hough he did make some shrewd points about international affairs in his last years, they did nothing to build confidence in the durability of mutualism - quite the reverse." ${ }^{20}$ Proudhon emerges from this analysis having made a few shrewd and judicious remarks about the value of liberty, but little more. Using his international political theory to elucidate his political theory seems only to have cemented Proudhon's negative credentials. Overall the conclusion is that Proudhon's system fails because he misunderstands the nature of international politics. However, this is a highly problematic reading of Proudhon's thought for two reasons. First, Ritter's methodology is flawed. I will show that if we approach Proudhon's theory of international politics on its own terms (rather than analytically, deductively and decontextually) we see that there is clear symmetry between his mutualism and his approach to international politics. Secondly, the contemporary value of Proudhon's

\footnotetext{
${ }^{17}$ See for example, Boucher [1998], Brown et al [2001], Williams [1992, 1996].

${ }^{18}$ Ritter [1969], p. 3.

${ }^{19}$ Ibid, p. v.

${ }^{20}$ Ibid, 146.
} 
thought is less important than the value it might have had at his time and whether it was realistic then. This, like so much else, we cannot discover in Ritter's analysis. I hope to provide this missing analysis here.

The historical literature on Proudhon's broader political theory, its emergence, context and influence is generally excellent. Despite its title, Hoffman's Revolutionary Justice: The Social and Political Theory of P-J Proudhon is a work of social history rather than social theory. It was based on his doctoral thesis in modern history at Brandeis University in 1968. It is also telling that the only engagement with Ritter's work comes in a bibliographical note in which he says that he "did not like it" - nothing more, nothing less. $^{21}$ Yet when Hoffman turns to Proudhon's work on international politics, he too fails to see its significance. Hoffman sees this aspect of his thought as a "philosophy of history more than anything else”, and he also argues that La Guerre et la Paix remains something of an enigma, concluding that the work is "little more than an awkward effort to provide a rationale for conclusions that he would have done better to offer and argue differently."22 Quite how Proudhon might have done this is not set out in detail, nor does Hoffman engage adequately with Proudhon's intellectual context. This, as I will show in chapter three, would have shown him that nearly all the major thinkers of the period framed international relations in this way. Moreover, if we take this context seriously we see that the arguments he presents are analytically and philosophically revolutionary, as well as internally consistent with his overall theory.

Nevertheless, what historical context Hoffman provides is helpful, and when read in conjunction with Woodcock's more sympathetic biography, ${ }^{23}$ is far more enlightening that Ritter's work. From both we learn about the nationalism of Proudhon's contemporaries, Proudhon's provincial upbringing in the hills of the Jura, and the broader social processes Proudhon was actively campaigning for and against - all of which are absent in the literatures surveyed thus far.

\footnotetext{
${ }^{21}$ Hoffman [1972], p. 376.

22 Ibid, p. 261.

${ }^{23}$ Woodcock [1956], pp. 219-245. This thesis traverses little if any of Proudhon's biography. Most other analyses of his thought take this tack. For an excellent short biography of Proudhon's life and times see Hampden Jackson [1957].
} 
Perhaps the best work to engage with Proudhon's international thought is Madalene Amoudruz' 1945 text Proudhon et l'Europe. ${ }^{24}$ It provides a good historical contextualisation of his thought. Amoudruz shows that what transpired in the totalitarian century after Proudhon's death was the "inverse" of what he had argued and campaigned for. Nevertheless, Proudhon is deliberately painted as simply an astute journalist with the common sense of the "petit paysanne". ${ }^{25}$ This is unfortunate. What we ultimately take from Amoudruz is that Proudhon's thought simply does not contain any of the deeper and more penetrating philosophical insights of his more illustrious contemporaries. This lack of intellectual contextualisation, also a flaw in Hoffman's work, has contributed to the myth of Proudhon's intellectual and political provincialism, a view reinforced by E. H. Carr who claimed that Amoudruz' work is indeed “[m]ore judicial” than most. ${ }^{26}$ I will rectify this in this thesis by contextualising Proudhon's thought within the dominant intellectual currents of his day, and by so doing show how deeply involved in these debates he actually was.

The final work of political and social history to note is Steven Vincent's Pierre-Joseph Proudhon and the Rise of French Republican Socialism (1984). This work is excellent. As the title suggests, Vincent locates Proudhon within the development of the French republican movement and ties his thought to the work of Rousseau and Montesquieu amongst others. While generally comprehensive, the work does not engage with Proudhon's international political theory or his underlying theory of justice to any significant degree. For example, there is only one index reference to La Guerre et la Paix, and Vincent admits that he does not engage with De la Justice, Proudhon's unquestioned magnum opus and the inspiration for La Guerre et la Paix, "in any detail". ${ }^{27}$ Vincent's aims are more to tie his early life, context and writings to his work on federalism. This thesis will fill an important gap in between these two periods.

\footnotetext{
${ }^{24}$ Amoudruz [1945].

25 ibid, p. 151.

${ }^{26}$ Carr [1950], p. 40 Other French literatures that focus on the historical and intellectual development of Proudhon's thought include: Guy Grand [1947], Halévy [1947], Dolleans [1948] and numerous other which this thesis has drawn on extensively.

${ }^{27}$ See, Vincent [1984], p. 318, 225.
} 


\section{Sociology}

Broadly speaking, the French secondary literature has taken a completely different approach to Proudhon's work. While many engagements are historical, most are sociological. For example, Celestin Bouglé, Raymond Aron and George Gurvitch all held chairs in sociology at the Sorbonne, and each wrote about Proudhon. ${ }^{28}$ Both Bouglé and Gurvitch both attempted to locate Proudhon's work in the French sociological tradition by showing the clear influence of Auguste Comte on Proudhon's thought, and that Proudhon engaged with similar debates and problems. ${ }^{29}$ Celestin Bouglé was also the coeditor of the Marcel Rivière edition of Proudhon's complete works. More recently, Pierre Ansart, himself a sociologist, has linked Proudhon's sociology to his federalist theory. ${ }^{30}$ In the Anglo-American literature only Constance Margaret Hall has presented the significance of Proudhon's sociology, building on the work of Bouglé, ${ }^{31}$ while only Aaron Noland has written on its relation to his philosophy of war and peace. ${ }^{32}$ This sociological literature needs to be brought to the attention of a wider English language audience since it captures an aspect of Proudhon's thought which neither the political theory or the historical work engages with. In doing this, I will show that Proudhon's work on international politics was historical, sociological, deeply philosophical and normative.

Finally, Edouard Jourdain's Proudhon, Dieu et la Guerre (2006) ${ }^{33}$ is perhaps the most recent analysis of Proudhon's approach to war. It is contextually sophisticated but lacks clarity and focus. My work differs from Jourdain’s in providing a full contextualisation and analysis of his approach to international relations rather than use Proudhon's ideas to answer theoretical problems relating to God and war. My analysis tells the story as

\footnotetext{
${ }^{28}$ See for example, Bouglé [1911], Gourevitch [1965, 1967], Aron [1966], pp. 600-610. For an analysis that shows how Proudhonism infused twentieth century French sociology, see Humphreys [1999].

${ }^{29}$ The best analysis of the influence of Comte, to which I will return in chapter three, is Haubtmann [1980].

${ }^{30}$ Ansart [1969, 1970, 1992, 1995].

${ }^{31}$ Hall [1971].

${ }^{32}$ Noland [1970, 1968, 1967].

33 Jourdain [2006].
} 
Proudhon did, and uses the contextualised narrative to contribute to Anglo-American IR theory - a literature which Jourdain is unfamiliar with. ${ }^{34}$

\section{International Political Theory}

International Political Theory is a recent development in IR, and seeks to reunite IR theory and Political theory. This move is an attempt to overcome the misconception that the two are mutually exclusive. This position has dominated realist approaches to international affairs and was an argument made explicit by the influential figure of Martin Wight and others. ${ }^{35}$ He famously claimed that there was no international theory before 1945 and that political theory's concern with state behaviour, law and order, is of little value in understanding the "recurrence and repetition" that characterises international anarchy. International Political Theory (IPT) rejects this claim, and evolved out of the critique of the standard statist ontology and historiography of the discipline of IR, particularly the way in which classical and neo-realists portrayed and constructed the canon of IR theory. ${ }^{36}$ Needless to say, a reappraisal of Proudhon's thought is still lacking, and anarchism as a political theory remains almost entirely absent. ${ }^{37}$

The exception that proves the rule is Parkinson's three page engagement with anarchism (and Proudhon in brief) in his comprehensive survey of political philosophers for their views on world politics. ${ }^{38}$ However, Brown, Nardin and Rengger, all three key figures in contemporary IPT, considered this survey "useful” ${ }^{39}$ but insufficient, precisely because of its breadth and its unavoidable lack of depth. In their 2002 restating of the IR canon, a

\footnotetext{
${ }^{34}$ Other excellent analyses of Proudhon's work that can't be engaged with in this thesis include Chambost [2004], which focuses on Proudhon's philosophy of law; Menuelle [1993], which argues persuasively that Marx’s key concept of surplus value can be traced back to his reading of Proudhon; and Guérin [1978], which argues that Proudhon's attitude towards women and other features of his thought can be explained by his "repressed homosexuality".

${ }^{35}$ Wight [1966], cf. Walker [1993].

${ }^{36}$ See for example Williams [1989, 1992, 1986], Hurrell [1990], Walker [1993], Brown [1992], Beitz [1979], Walzer [1992].

${ }^{37}$ See for example Boucher [1998], Kauppi and Viotti [1992]. Not a single textbook, reader, anthology or collected volume of essays in IR engages with anarchism. Defining IR is beyond the scope of this thesis, needless to say, even if we look outside the traditional boundaries, Proudhon is also largely absent there.

${ }^{38}$ Parkinson [1977], pp. 146-149.

${ }^{39}$ Brown et al [2002], p. 15.
} 
restatement that explicitly seeks to supersede the extant literature, they leave the anarchists out altogether.

However, periodically over the last thirty years or so, some (though strikingly few it has to be admitted) have actively called for a return to anarchist political theory in IR. They have generally argued that anarchism has the potential to help us think through contemporary world politics and can help challenge some of the key presumptions of the discipline in the process. The first to do so was Thomas Weiss who, in 1975, argued that anarchist approaches to the question of autonomy and authority ought to be seen as vital to the normative foundations of any planned future world orders. Anarchism provides normative and institutional arguments for radically pluralizing, democratising and deepening the structures of the post-Breton Woods international organisations. ${ }^{40}$ Four years later, Richard Falk argued that anarchism is "alive to the twin dangers of socialism and capitalism if pursued within the structure of statism”, an argument I will echo. However, somewhat typically of the 1970's left, Falk favourably compared anarchism to Maoism, arguing that anarchism could gain "some historical credibility" ${ }^{41}$ from a closer association with Maoism! He also argued that,

As yet there is no comprehensive and satisfactory formulation of an anarchist position on global reform, only fragments here and there; a well-integrated statement could help crystallise enthusiasm for global reform [particularly of transnational governmental bodies] of a drastic, yet constructive kind. ${ }^{42}$

In the past thirty years, the rise of new social movements and anti-authoritarian approaches to world order reform, have gained much currency. ${ }^{43}$ However, Falk's suggestion cements the general ignorance surrounding Proudhon's 2000 pages on the problems of nineteenth-century world order, and their potential to help us think through these issues today.

\footnotetext{
${ }^{40}$ Weiss [1975].

${ }^{41}$ Falk [1979], p. 82

${ }^{42}$ Ibid.

${ }^{43}$ For a good overview see, for example, Graeber [2002] and Gordon [2007].
} 
Publishing in the Journal of Peace Research, twenty three years after Thomas Weiss' article in the same publication, Scott Turner called for a return to anarchism to help us think beyond the enduring political, analytical and moral strictures of political Realism in IR. He suggested that an anarchist approach to IR would be able to account for, and provide a new paradigm with which to explain, the pluralisation of world politics. ${ }^{44}$ The Hobbesian state-centric model of analysis, he argued, inhibits good analysis of world politics, while the picture Realism paints of the world actively encourages the very monopolisation of force and power by the state that civil society movements protest. Turner argues that Kropotkin's gentler theory of mutual aid is a good and useful corrective to more mainstream Realist positions. Proudhon's thought is again overlooked. $^{45}$

Finally, in 1998, Andrew Linklater, the current Woodrow Wilson Professor of International Politics at Aberystwyth, a chair once held by E. H. Carr, called for a turn to anarchism. He argued that in the wake of innumerable critiques of realism and its a priori commitment to state sovereignty, and given new, more pluralist understandings of political community offered by critical approaches to world politics and political theory, anarchism can furnish us with a better understanding of republican citizenship in a "postWestphalian” political order. ${ }^{46}$ I hope to answer each of these calls directly.

\section{Understanding the Contribution of the Thesis}

Linklater's work is doubly important here because of the critical theory he and others have brought to bear on the statist mainstream in IR theory. In an influential paper in 1996, Linklater outlined the "Achievements of Critical Theory" in IR. ${ }^{47}$ The four achievements he discusses have profound significance for the way in which I position

\footnotetext{
44 Turner [1998].

${ }^{45}$ Mike Sheehan has also penned but has not published two articles on the benefits of anarchism for contemporary security studies. See Sheehan [1999, 2004]. Neither reference Proudhon's thought.

${ }^{46}$ Linklater [1998], p. 196. Linklater references Weiss [1975] as his starting point.

${ }^{47}$ Linklater, [1996].
} 
this thesis within contemporary IR theory. Critical theory in IR borrowed heavily from Frankfurt School Critical Theory and differs from postmodernism in that it seeks to retain the centrality of reason and continues to seek the emancipatory potential within modernity. In relation to IR theory, Linklater argued that the first "achievement" of this type of critical theory was to provide a trenchant critique of the positivist philosophy of science that dominates IR. The second aspect of this critique was to undermine dominant theoretical and ontological claims regarding the structural immutability, and irreducible autonomy, of the states system. This immutability is also reinforced by the "problem solving” approach of positivist-inspired IR theory. Thirdly, Linklater noted how critical theory had developed a critique of rump materialism on the right, and class and production on the left, both of which had dominated social theory for the previous thirty years or more. The move away from orthodox Marxism and a crude structural realism in IR, allowed other issues to the fore. ${ }^{48}$ Finally, Linklater argued that critical theory provides the analytical and normative tools to articulate a critique of the processes and boundaries of political, social and economic exclusion otherwise ignored while production, statism, materialism, an amoral positivism, and an ethic of 'interests' dominated thinking in IR theory.

These critiques, also pioneered by Robert $\operatorname{Cox}^{49}$ and Richard Ashley ${ }^{50}$, have moved IR theory's research agenda towards discovering the motors of change and the principles of stasis within a deeper conception of both the international and the political in international relations, and in IR as a discipline. The result has been a distinctive shift towards a historical and political sociology of world politics ${ }^{51}$ - a shift that is arguably long overdue, but the inevitable outcome of the rejection of the statist and rationalist project of the nineteenth and twentieth century, and their catastrophic consequences for human life.

\footnotetext{
${ }^{48}$ Linklater [1990].

${ }^{49}$ Cox [1981].

${ }^{50}$ Ashley [1984].

${ }^{51}$ See for example, Creighton and Shaw [1987], Linklater [2004], Mann [1988].
} 
What is so surprising is that this contemporary move in IR theory is a remarkable and unconscious repetition of the arguments Proudhon made all those years ago. While Proudhon's arguments were made in radically different times, they were made for the much the same reasons. Proudhon questioned and reformulated the newly devised sociological positivism of Auguste Comte, the teleological Kantian philosophy of history, the claims about the immutability of the social order espoused by the religious right, and the ahistorical nationalist statism of Rousseau. Proudhon also criticised the Jacobin communism of Louis Blanc, the providentialism of the liberal Saint-Simonian technocrats, and the capitalist doctrines of laissez-faire. By standing fast to a commitment to individual and group autonomy, a sociological and moral ontology, anti-dogmatism in social theory and an openness in historical analysis, he broke decisively with each of these authors - in particular in relation to their statism - and in so doing devised anarchism as an alternative political paradigm.

As Alexander Herzen, one of the most prominent Russian revolutionaries of the mid to late nineteenth century, observed at the time: "Proudhon is the first of a new set of thinkers. His work marks a transition period, not only in the history of socialism, but also in the history of French logic.”52 It will be argued that Proudhon's thought was arguably the first comprehensive break from the state-based, materialist and deterministic paradigm that dominated modern social theory, particularly on the left, within fifty years of his death. Indeed, it is against this past dominance that contemporary critical theory is directed. As such, what needs to be explained is less how Proudhon might contribute to contemporary IR theory but how and why IR theorists like Linklater are making Proudhonist arguments and calling for a return to his ideas. ${ }^{53}$ Of course we cannot address this issue before we have a full account of Proudhon's arguments. Careful research design is thus vital to substantiating the historical, analytical and political claims this thesis makes.

\footnotetext{
${ }^{52}$ Cited in Jackson [1958], p. 115.

${ }^{53}$ Linklater is reflective of a broader literature which makes similar arguments. For example, see also Held [1984, 1995], Walzer [1992], Hirst [1994].
} 


\section{Research Design 1: Methodology}

The starting point of this thesis is a contextualist approach to the history of ideas based on the work of Quentin Skinner. ${ }^{54}$ This approach emphasises the importance of understanding intellectual and social context for finding the meaning of texts in the history of political thought, as well as the intentions of their authors in writing them. What I want to do here is to explain Skinner's approach to the history of ideas through reference to the reception of Proudhon and anarchism more broadly in Political theory and IR. This will bring to life the methodology in a way that will set the context for the revisionist exegesis of Proudhon's thought to follow.

In his classic essay 'Meaning and Understanding in the History of Ideas' (1969), Skinner outlined four persistent mythologies that shape approaches to the ideas of past thinkers. These are: a mythology of doctrines, a mythology of coherence, a mythology of prolepsis, and finally a mythology of traditions or paradigms. I will return to the detail of these myths below, however what Skinner argued was that these myths hamper our ability to come to understand the intentions of past authors, and justify the imposition of meaning on texts, meaning usually related to contemporary concerns.

This rubbed against the grain of traditional approaches to the history of political thought precisely because, as Runciman puts it, "political philosophy [...] more or less ceased to exist between Sidgwick and Rawles, and the fundamental questions of political philosophy $[\ldots]$ were handed over to economic and social theorists fundamentally uninterested in the broader political and moral context in which those questions might be posed". 55 This rationalist and analytical approach to political philosophy involved abstracting from the messy business of life and devising rationally coherent deductive theories regarding the best way to live an act - a tradition into which Ritter's work on Proudhon clearly falls.

\footnotetext{
${ }^{54}$ Skinner [1988].

${ }^{55}$ Ibid, p. 98.
} 
What Skinner also argued was that ideas in the past are not artefacts to be brought forward, unproblematically, to the present. While past ideas must always be made sense of through our contemporary lenses, it is only through investigating the author's intention, by understanding his (it was rarely her) context, that we can actually learn anything new at all. Without this historical context the past can only be used to reinforce contemporary ideas, since the actual history of political thought drops out altogether.

Prioritising the present produces four persistent and damaging myths in the history of political thought. The first such mythology is that of "doctrines" and by this Skinner means that a particular tradition of political thought is said to comprise of a series of core paradigmatic assumptions. Contemporary, decontextualised, understandings of these assumptions shape the historians expectations. The evidence subsequently brought forward is then said to represent the thinking of the historical figure under question because it reinforces assumptions held in the present. The actual history of ideas drops out.

For example, C. B. Macpherson comes under attack from Skinner for assuming Locke and others were "possessive individualists". Skinner's claims that this cannot have been the case since what we understand as "individualism” simply did not exist, even if (in fact precisely because) Locke is commonly held to be proto-liberal today. What Skinner argues is that "the history can only be reinterpreted if the paradigm itself is abandoned."56 In relation to Proudhon, this suggests that one needs to question the persistent assumptions surrounding his thought. Perhaps more importantly, we may also need to suspend all our preconceptions of what anarchism is if we are to understand the idiosyncrasy of Proudhon's thought at all.

Typically however, problems do not end here. This mythology of doctrines tends to feed into a "doctrine of coherence". Once a set of preconceptions about the key elements of a particular ideology becomes established, their absence in a particular author (or the presence of ideas that do not fit our preconceptions) are seen as impediments to our

\footnotetext{
${ }^{56}$ Skinner [1988], p. 36.
} 
understanding of his or her thought. This approach clearly assumes that a text "has to await the future to await its meaning". ${ }^{77}$ This is what Skinner calls the "mythology of prolepsis" and it is perhaps the characteristic flaw of all analyses that fails to accord context a dominant place in the history of ideas. Skinner is thus clear; there is no Archimedean point (or theory) in the present from which the past gains its true meaning. What this also implies, however, is that through according context a more prominent place we get better accounts of the intentions of past authors.

And finally, Skinner makes the point that histories and accounts of a particular set of ideas are commonly written in the interests of present concerns. The canon is written in order to sustain ideas about what are essentially anachronistic lineages. As the work of contemporary historians of IR theory has shown, this was clearly the case with Realism, but even recent accounts of the history of anarchism marginalise Proudhon's thought based on what anarchism is supposed to mean today. ${ }^{58}$

To avoid the consequences of these four mythologies, Skinner advocates a return to context. He does not argue that context determines the content of a text, nor does he argue that a text "should be understood in terms of its social context". ${ }^{59}$ A good example of this type of contextualism can be found in Carr's work on Proudhon. He claims that his nationalism and chauvinism are explicable by the fact that "he was the very embodiment of the French [petit bourgeois] ideal", and that his "local patriotism" are the result of his Franche Comtois rural background. ${ }^{60}$ This simply will not do, but it is a persistent approach. Indeed, Vincent's recent review of John Ehrenberg's Proudhon and His Age makes much the same point about this work. He argues that if one wants to understand Proudhon,

through the ideological lenses of reductionist Second International Marxism then Ehrenberg's book is to be recommended. If on the other hand, one

\footnotetext{
57 ibid, p. 45.

${ }^{58}$ See, for example, Kinna [2005].

${ }^{59}$ Skinner [1998], p. 59.

${ }^{60}$ Carr [1950], p. 49.
} 
wishes to understand Proudhon in terms of his own historical period or to approach Proudhon in terms of the scholarship of the past thirty years [including developments in French social and political history], then one must look elsewhere. ${ }^{61}$

As I will show in the chapters to follow, it has now become easier to understand Proudhon because we now better understand his times, and this is possible because of the abandonment of reductionist and Marxist approaches to French history and ideas. This thesis takes full account of this literature, and, not only do we get a different picture of Proudhon, we also get a different picture of the nineteenth century, its evolution, the foundations of the twentieth century, and how we might rethink our own times.

However, even if we accept Skinner's argument that we cannot explain texts in terms of context, we could still argue that Skinner undervalues the causal powers of the material context on our political ideas. Skinner's method leans heavily on "speech act theory". This approach, built on the work of Austin and Searle, is heavily hermeneutic. This foregrounds an inter-textual and "illocutory" context. Skinner's aim, particularly in his work on Hobbes, ${ }^{62}$ was to account for the change in emphasis in Hobbes' use of rhetoric between De Cive and Leviathan. This demanded a detailed analysis of Hobbes' schooling and his intellectual context to explain the change in his ideas.

Wile this approach prompted Skinner to call for an abandonment of the approach to Hobbes that sees him as a progenitor of rational choice theory, speech act theory would not be suitable as a method for this thesis. Proudhon was almost completely self-taught and his reading was wide-ranging and unsystematic. ${ }^{63}$ For example, in a four month period from 1839-1840 Proudhon read 25 texts, including Kant's Critique of Pure Reason, two of Montesquieu's works, Michelet Introduction to a Universal History and a number of others. This pattern was repeated throughout his intellectual development and has implications for how Proudhon's thinking developed and where we might claim his

\footnotetext{
${ }^{61}$ Vincent [1997], pp. 1174.

62 Skinner [1996].

${ }^{63}$ Vincent [1984], 62.
} 
ideas came from. What I argue is that we need to place Proudhon's work in a more sociological context. This thesis takes account of the broader tendencies in French intellectual life, transformations in the material structures of society, and the machinations of inter-state relations, as well as Proudhon's own intellectual development.

Vincent's Pierre-Joseph Proudhon and the Rise of French Republican Socialism is the best existing, self-consciously contextualist, approach to Proudhon’s work. ${ }^{64}$ This work fully achieves what it sets out to do, namely,

to show that, contrary to persistent legend, Proudhon was not the egregious eccentric who continually contradicted himself. A careful reading of his major works, notebooks and correspondence, examined in terms of the historical context, induces one to recognise that Proudhon had a consistent vision of society and its needs, a vision which is pre-eminently moral, and which revolves around his desire to install a federal arrangement of workers' associations and to instil a public regard for republican virtue. ${ }^{65}$

My work substantiates this claim and does so by presenting a detailed analysis of the only aspect of Proudhon's thought that is missing in Vincent's excellent analysis: his work on justice, international relations, war and peace. I also provide a far more detailed analysis of Proudhon's political philosophy, rather than his republicanism, by focusing on the influence of the work of Rousseau, Kant and Comte. Nevertheless, our readings of Proudhon ought to merge and overlap in significant ways because our method allows us to read him more clearly and also more consistently. While Vincent's background as a historian of the French left, and mine as an IR theorist, explains the focus of our research, it ought not to substantially affect our understanding of Proudhon's ideas as a whole if, and this is significant, if Proudhon was himself consistent. Our analysis suggests that he was broadly consistent and one might legitimately conclude that if ever there was a thinker that needed a dose of Skinnerian reappraisal, it is Proudhon.

\footnotetext{
${ }^{64}$ Vincent explicitly acknowledges his debt to Skinner. See Vincent [1984], p. 235.

${ }^{65}$ Vincent [1984], pp. 3-4.
} 
In sum, my work is based on the assumption that reality exists independently of what we might think about it. I am an ontological and scientific realist and an epistemological or methodological pluralist. I recognise that method changes the way we see the world, but that reality is infinitely too complex to privilege one method over all others. Moreover, I support the position that our ideas are context specific and that the reality of this context is that it evolves and changes over time. Investigating the history of ideas is thus an exercise in philosophical realism, for without it history cannot exist in any independent way. Thus, the historical record becomes the measure of my analysis, and should that record be changed or reinterpreted then so much the better. But it is that record that ultimately sets the parameters of our truth claims and emplots our narratives, nothing else. However, I recognise that method and fact are not normatively empty concepts quite the opposite. If our facts are wrong then it is likely that any values we chose to base on them will be too. Moreover, I believe it is worthwhile and valuable that analysis should be driven by value commitments, but that these commitments ought to be flexible enough to change if analysis suggests that they should. This is what research in international political theory is ultimately for.

\section{Research Design 2: Research Questions}

This thesis seeks to answer two deceptively simple questions:

\section{What did Proudhon say about international politics and why?}

\section{Can his thinking in this area contribute to contemporary IR theory?}

Answering these questions is no easy matter, as I hope I have made clear. First, as no full exegesis of Proudhon's thinking about international politics exists in the English language, answering the first question is the precondition to the second. Secondly, since his works have been so roundly misunderstood, the thesis must provide a better account of them. Thirdly, if the thesis is to avoid the mythologies of parochialism and prolepsis, doctrines and traditions, the narrative must try, at least, to avoid forcing Proudhon's ideas into contemporary problems, terminology, and approaches. 
Proudhon's published works now number in excess of 50 volumes, and both the completed works and individual texts have been through numerous editions - a few of which have been translated into English. The primary texts for this thesis are those published monograph works, written by Proudhon between 1858 and his death, which relate to his thinking about world politics. These are: De la Justice dans la Révolution et dans l'Église, Études de philosophie pratique [1 $1^{\text {st }}$ edition 1858, $\left.2^{\text {nd }} 1860\right]$, La Guerre et la Paix, récherches sur la principe et la constitution des droits des gens [1861], La Fédération et l'Unité en Italie [1863], La Pologne, considerations sur la vie et la mort des nationalités [unpublished, c. 1863-1864], Du Principe Fédératif et de la Nécessité de reconstituer le parti de la révolution [1863], which includes Si Les Traités de 1815 ont Cessé d'Exister, Nouvelles Observations sur l'Unité Italienne [1865], and finally France et Rhin [1868].

I do not engage substantively with Proudhon's letters and notebooks for three main reasons. First, the absence of a full exegesis of his published works makes providing one a priority. Secondly, his letters and notes have been well studied by others. ${ }^{66}$ Finally, from 1856 until his death, Proudhon wrote a diminishing amount in his notebooks and his letters become less relevant to understanding his monographs. ${ }^{67}$ Nevertheless, I have in places referred to letters, notes and annotations for narrative purposes.

Finally, the thesis is not uncritical of Proudhon's thought. While it has been hugely exaggerated, he was nevertheless anti-Semitic; but he was consistently and arguably far more virulently, anti-feminist. The former aspect of his thought has been the subject of numerous rather one-sided analyses, but perhaps unsurprisingly, the latter has not. ${ }^{68}$ Space does not allow a full discussion of Proudhon's anti-Semitism, but unlike his antifeminism, his anti-Semitism is not a feature of his thinking that is crucial to our understanding of his thought in general. Proudhon's anti-feminism is another matter. I

\footnotetext{
${ }^{66}$ See for example Dolléans [1945].

${ }^{67}$ Haubtmann's recent work is invaluable here [1982, 1987].

${ }^{68}$ See for example, Silberner [1948], Schapiro [1945], Wistrich [1995] On his anti-feminism see Haubtmann [1988b], pp. 58-71, 221-225; Gemie [1966]; D’Héricourt [1981].
} 
will show that it is deep-seated in his socio-cultural origins, his intellectual forebears, and his own framing of sexual relations. While Jews are not, French feminists, on the other hand, come under constant and deliberate attack, and his anti-feminism forms a vital part of the narrative he gives of world politics, as I will show. On the surface his antifeminism severely undermines his political and social theory - it is what I call a firstorder contradiction in his thought, and can be contrasted with the slippages and changes of attitude that constitute the majority of his second-order contradictions.

However, I will argue that we can explain the origins of his anti-feminism, and that feminism actually provides the best available critique of Proudhon's thought. What we find is that using feminism to undermine Proudhon's theory on its own terms nevertheless leaves it with a functional coherence that loses none of its potency without his anti-Feminism. This is a method of immanent critique, using Proudhon's own ideas and analytical categories against him, and follows explicitly in the footsteps of the work of Proudhon's contemporary, also from Besançon, the feminist Jenny d’Héricourt. ${ }^{69}$ D’Héircourt attacks Proudhon's ideas in such a way as to show that they are also influenced by cultural, historical and political bias.

\section{Research Design 3: Chapter Outline}

Given my aims, the thesis is broadly divided in two. The first half provides the context and the second provides an exegesis of Proudhon's international political theory. Chapter one turns to European interstate relations at the time. I provide a snap-shot of nineteenthcentury international relations derived mostly from Proudhon's works and substantiated by the existing secondary literature on nineteenth-century international relations. By following the narrative of three books that engage with four main subject areas of note, I will show that he was indeed the astute social critic Amoudruz shows him to be, and that his criticisms of the trajectory of European politics have been vindicated by the tragic course of European history. Proudhon discusses Italian unification, the Polish question,

${ }^{69}$ D’Héricourt [1981]. 
the issue of France's natural frontiers and the Rhineland, and the 1815 congress of Vienna. Proudhon argues for the entrenching of the 1815 European balance of power. He criticises Napoleon III, Mazzini, Cavour and the French democrats for stirring up nationalist sentiments which he thought would destroy this fragile new order. This position earned him the ignominious title of counter-revolutionary. With historical hindsight it is perhaps fairer to call him a visionary. I conclude by showing in brief how and why Proudhon believed the European political order should be based on a model of Swiss federalism. The remainder of the thesis will substantiate this argument by discussing the philosophical, historical and normative arguments he uses to support his claim.

Chapter two provides a slice of the social and political context of nineteenth-century France. What I argue is that the intellectual and social currents in modern France were coalescing around the state as both the primary focus of attention and also the primary vehicle of social change. From French feminism to the emerging nationalist doctrines, the argument was being developed that if the internal make up of states could be bettered, preferably along French republican lines with France at the forefront of European order, international politics would be pacified or would simply cease to exist. The vast majority were blind to the militarization of the French state at this time, and loyalties towards the state changed with time from civic-military élan at the turn of the nineteenth century, to republican anti-statism in the aftermath of the Paris Commune. Showing how the focus of the majority of those who studied political affairs was largely inward-looking, will contrast with Proudhon’s unique approach to international and social affairs.

Chapter three develops this context further by taking a step back from the social mêlée and analysing in detail the ideas of Rousseau, Kant and Comte. Rousseau had a significant influence on the work of Kant, and Kant on Comte, and all three shaped how Proudhon (and the left more broadly) developed their philosophical approach to international relations. Providentialism and teleology united these three writers in relation to their thinking about the future "perfectly just civil constitution" as Kant called it. ${ }^{70} \mathrm{I}$

\footnotetext{
${ }^{70}$ Kant [1991a].
} 
will show that their approaches to matters of international politics were deeply philosophical and couched almost entirely within the terms of their providentialist or teleological philosophy of history. Their approach suggested that enlightened imperialism would produce freedom, and that this was either divinely or historically ordained. Both among the revolutionaries and the intellectual elite, ideas about imperialism were spliced together with the historic mission of France and resulted in the catastrophes of the Franco-Prussian wars and the Paris Commune. This context is vital if we are to understand why Proudhon approaches international relations from the perspective of the philosophy of history, and what the value of this approach is in terms of his theory of justice.

In chapter four I argue that if we want to understand Proudhon's international political theory we also need to understand it within the context of his intellectual development. That is, his theory of international politics ought to be understood as a natural development of his thinking about justice in general. Here I give a full analysis of his theory as set out in De la Justice dans la Révolution et dans l'Église. What I will show is that Proudhon's theory of justice as immanent equilibrium borrowed heavily from Comte and Kant but was uniquely his own. What I show is that while developing this theory Proudhon was already thinking about world politics and how his theory of justice would need to explain this too.

Chapter five shows how Proudhon did this. I illustrate that for Proudhon, international relations were relatively autonomous social relations that structured political and social life, mainly through war and the preparation for it. Proudhon also shows that macro norms of social justice, those codes by which society organises its internal affairs, are themselves the product of war and the machinations of inter-state behaviour. For Proudhon international politics have qualitatively different properties to social relations, and are structurally determining of domestic politics. Having outlined the basics of his socialist critique of the liberal order in chapter four, here he develops it into an explanation for the causes of war. Proudhon argues that war is caused by ruptures in the economic equilibrium. These ruptures are more often than not themselves caused by 
famine, greed, parasitism and destruction, but can also be caused by the internal development of imbalances such as those caused by militarism or statist dirigisme. The state and capitalism, Proudhon argues, effectively exacerbate social relations and cause conflict.

In chapter six I will show that Proudhon develops his theory of federalism and economic mutualism as a solution to his conflict-ridden world order. Central to this was the embedding of the 1815 balance of power and a drive towards deepening the constitutional tendency of European states. He argued that all social cleavages should be federated and the economy democratised. Proudhon's anarchism is both more radical and more conservative than one might at first assume, but it is unquestionably more practical and realistic than the millenarian utopianism of his contemporaries. Unfortunately, as Amoudruz has noted, what actually transpired in the 100 years since his death was the opposite of what he had called for. However, what is most surprising is that what began to happen after the Second World War is that his ideas have slowly found echo in the ideas and political projects of contemporary IR theorists. In chapters four, five and six, Proudhon's ideas are criticised from a feminist perspective, by building on the work of Jenny d'Héricourt, first published in 1864.

In the conclusion I will show how this re-appraisal of Proudhon's thought, and the way in which I have done it, can help us understand contemporary IR theory. I argue that rather than help us solve contemporary problems, turning to context allows us to see why our problems have come to be approached in the ways they have. What I show is that contemporary critical IR theory takes most of Proudhon's key problem fields seriously and approaches them in much the same way. I aim to show here that the contemporary reassessment of IR's statist past has taken place because it has become clear that those approaches produce the very thing they claim only to analyse - war. It is my contention that Proudhon's thought can help us understand the pre-requisites of a just and progressive peace in the $21^{\text {st }}$ century. 
Part 1: Context 


\section{Chapter 1}

\section{Nationalism and the Nineteenth-Century \\ European Balance of Power}

Un jour viendra, qui peut-être n'est pas éloigné, où ce mouvement de concentration se changera en un mouvement opposé: ce sera lorsque l'expérience du système parlementaire et bourgeois sera devenue générale, et que les grandes questions économiques auront été mises à l'ordre du jour. Alors la révolution sociale, manquée en Février 1848, s’accomplira pour toute l'Europe. Pour le moment, il est incontestable que l'opinion, sur tous les points, est en majorité unitaire. ${ }^{1}$

\section{Introduction}

I have two interconnected aims in this chapter. First, I want to outline the structure and international political dynamics of nineteenth-century European politics through Proudhon's eyes, to illustrate the first layer of context within which Proudhon's ideas about world politics developed. This context is vital if we are to understand the political engagement that underpins Proudhon's metaphysics, and if we are to get some idea of the shape of European and world politics at that time. The main feature of this period was the rise of nationalism and the doctrines of national unity and their threat to the fragile European political order. Secondly, by analysing this context through Proudhon's eyes I will develop a number of political, philosophical and normative questions, which arise from his analysis, and which it is the purpose of the remainder of the thesis to answer.

We will see is that Proudhon had a very particular way of analysing European international relations, and also a unique way of thinking beyond them. What needs

\footnotetext{
${ }^{1}$ Proudhon [1998], p. 219.
} 
explaining, and what I will show, is why Proudhon sees the structure of European power relations as politically, ontologically and normatively prior to domestic concerns. In other words I will make it clear why Proudhon was so concerned with world politics as a distinct and relatively autonomous realm of political activity, which many were relatively ignorant of, and what he proposed to do about the problems he saw. The aim of the second half of the thesis will be to provide a full account of the theory he develops to give philosophical depth to this approach to world politics.

It ought to be noted that this chapter does not aspire to present a full nor a balanced understanding of European political relations in the nineteenth-century, nor of the rise of nationalism. The chapter aims solely to provide an account, and corroboration, of Proudhon's approach to the period. Because I will be structuring the chapter in this way it is important to first say a few words about the general impression of Proudhon's thinking in this area. I will then be able to illustrate how surprising it is that there is such significant correspondence between Proudhon's observations and more contemporary work in this area. By framing the chapter in this way, the historical and intellectual importance of Proudhon's thought will become clear. It will also present us with something more to explain.

Turning first to the minimal engagement with Proudhon's work by Carr, what has already been mentioned is that he read a more or less chauvinistic desire to promote French interests in Europe into Proudhon's analysis. This is an opinion shared by Paul Thomas and repeated by Carl Levy. ${ }^{2}$ Levy, Thomas and Carr use this observation to justify paying minimal attention to Proudhon's writings in this area, since, by their estimation, it cannot contribute to our understanding of the anarchist and socialist internationalism that followed Proudhon, since chauvinism is precisely what they rejected. ${ }^{3}$ However, Proudhon's chauvinism is hugely exaggerated. As I will show, Proudhon defended the European balance of power, less in France's interests than in Europe's. That it was common at the time for French intellectuals to see the destiny of Europe as coterminous

\footnotetext{
${ }^{2}$ Carr [1950], Thomas [1980] cited in Levy [2003] p. 333.

${ }^{3}$ See also Knowles [2006].
} 
with that of France, a topic I will discuss at length in the following chapter, seems to have clouded readings of Proudhon's thought here.

This analysis has had significant knock-on effects. Benedict Anderson, one of the most famous scholars of nationalism, has recently turned his attention to the anarchist and antistatist nature of nineteenth-century nationalist and anti-colonial movements in Cuba and the Philippines. But again, Proudhon's thought barely features. This is an unfortunate oversight since Anderson's key biographical character, the Filipino revolutionary José Rizal was heavily influenced by the ideas of his good friend, the Catalan Pi y Margall who became president of the first Spanish Republic in 1871. Margall also assisted in drafting Spain's first republican constitution and had by then also translated four of Proudhon's key works on mutalism, nationalism and the philosophy of history into Spanish. ${ }^{4}$ Proudhon's thought had significant, though unacknowledged, bearing on the radical federalism and anti-statism of the period.

Perhaps of more significance for the reception of Proudhon's thought has been the treatment of it by Alan Ritter. Due to his analytical methodology and his explicit desire to develop a internally coherent political theory from Proudhon's work, and despite using Proudhon's writings on international politics to elucidate his political theory, Ritter mentions neither nationalism nor the actual international politics of Proudhon's time at all. ${ }^{5}$ This contributes to the general ignorance of Proudhon's writings on this subject and has allowed seminal commentators on the political philosophy of anarchism such as David Miller, who relies heavily on Ritter's account of Proudhon, to argue that,

National sensibilities can be artificially inflamed, but they cannot be created out of nothing. Their blindness to this fact and its political implications may

\footnotetext{
${ }^{4}$ Anderson [2006], p. 107. For an excellent account of Margall's debt to Proudhon see Hennessy [1962], pp. 22-31. Margall's translations of Proudhon's De la Capacité Politique des Classes Ouvrières and Philosophie du Progrès both appeared in 1869. The first edition of his translation of Du Principe Fédératif appeared in 1868, the second in 1872 along with Systèm des Contradictions Economiques.

${ }^{5}$ Ritter [1969].
} 
be a major factor in explaining the anarchists' failure to win many converts among the masses of modern Europe and America. ${ }^{6}$

Miller's now famous nationalist communitarian position is premised upon the argument that "without such a body [as the state] the nation remains inchoate and directionless"7, thus leading to a wholesale rejection of anarchism as incompatible with real nationalism and thus with the march of twentieth century history. This approach utterly decontextualised the actual political struggles that went on during this period. Anarchism was not one idea among many that people could choose from in order to help make sense of the world. Anarchism's failure is not demonstrable by contemporary history any more than the Reformation, for example, proves Catholicism's inherent weakness. The rise and fall of ideas needs better explanations than this Whig view of history can provide.

On an empirical note, Chris Brown ${ }^{8}$ has called the attention of IR and political theorists to the fact that the nation state is a fairly recent invention, and that if we want a fuller understanding of the linking between nation and state, tracing the intellectual and social history of the nineteenth century in relation to both is vitally important. ${ }^{9}$ What Brown suggests is that the historical relationship between the rise of state and nation is highly complex and must be demonstrated rather than assumed. However, given the general ignorance of the anarchist position on the issue of nationalism and the state in international politics, Brown et al's excellent compendium on the subject of nineteenthcentury approaches to nationalism from and international perspective overlooks the anarchists entirely. This is a historical and analytical oversight that has no warrant, but is perhaps explicable by the general absence of Proudhon's approach to the subject in anarchist, as well as other secondary literatures.

As more attentive analysts of Proudhon's thought have shown, from the Crimean War (1853) through to his death in 1865, the rebirth of French Imperial ambition and

\footnotetext{
${ }^{6}$ Miller [1984], p. 179.

${ }^{7}$ Ibid., p. 181. cf. Miller [1999].

${ }^{8}$ Brown [2002].

${ }^{9}$ Brown et al [2002], p. 457.
} 
Napoleon III's championing of the rise of nationalism as a political credo, was what turned Proudhon's attention to world politics in the first place. ${ }^{10}$ A cursory glance at the titles of his published works during this period also shows that the lens through which Proudhon understood this international context was the relationship between nationalism, the state, and the mutual role of socialist and non-socialist revolutionaries in the consolidation of the modern nation state, and by extension modern international relations.

This first chapter therefore engages directly with three key problems in European international relations at the time and is driven by Proudhon's analysis of them. The first is what was known as the 'Italian question' and here Proudhon's La Fédération et l'Unité en Italie (1862) and Nouvelles Observations sur l'Unité Italienne (1864) are the key texts. The second is 'the Polish question' and here the analysis of the Polish issue he presents in Si les Traités du 1815 ont Cessé d'Exister: Actes du Futur Congrès (1863) forms the driving part of the narrative. This work is a synopsis of his unpublished ' $\mathrm{La}$ Pologne, Considérations sur la vie et la mort des nationalités'. The analysis will be supported by his theory of social order taken from $\mathrm{Du}$ Principe Fédératif, ou de la nécesité de reconstituer la partie de la révolution (1863), which I will develop considerably in chapter six. The third section turns to the problem of France's 'natural frontiers' as presented in by Proudhon in France et Rhin, which was published posthumously in $1867 .{ }^{11}$ The conclusion takes Proudhon's constant reference to the much ignored anomaly of European nationalism - Switzerland - seriously, since, contrary to the popular belief in Proudhon's chauvinism, it is the outline and then contemporary model for his ideal society. Once this practical illustration of Proudhon's solutions to the problems of European nationalism is presented, I will ask the question this thesis will seek to answer: what are the philosophical and historical foundations for this claim?

\footnotetext{
${ }^{10}$ See for example, Amoudruz [1945] Haubtmann [1988b], pp. 161-162; Woodcock [1956], pp. 223-269. For an excellent analysis of his letters during this formative period of his writings see Dolléans [1948], pp. 370-388.

${ }^{11}$ The analysis here will be taken from the second edition published the following year. Proudhon also engages with the politics of colonialism in Algeria and Mexico, the American Civil War and its implications of political liberty, the decline of the Ottoman Empire and the problems the new nations may pose for the European order and so on. The sheer breadth of his analysis, and the consistency in his normative propositions, make his works excellent documentary sources for historians of the nineteenth century.
} 
Following Proudhon's narrative in this way performs two important functions. First, it allows the narrative to speak from the perspective of a nineteenth-century observer, as opposed to contemporary theoretical and political debates and interpretations. Because of the very real transformations underway at this time this allows us to disrupt the contemporary 'obviousness' of our way of framing the international and the domestic, the relationship between state and nation that we have come to accept. Nevertheless, since I have had to corroborate Proudhon's analysis by reference to contemporary texts, it is inevitable that my narrative will speak to contemporary issues, while also diverging in key areas. This brings me to the second, subsidiary function of the chapter: to illustrate quite how perceptive Proudhon was, and how striking it is that his thinking in this area has been overlooked. I will support Rocker's observation that Proudhon, with a notable degree of accuracy, foresaw the trajectory of nineteenth-century international politics; ${ }^{12}$ the end-point of which, as we all know, was the rise of what J. L. Talmon has called "totalitarian democracy", ${ }^{13}$ the beginning of the end to European Empires, and two world wars.

However, this turn to contemporary literature raises two methodological problems. First, which contemporary literature ought to be used to evaluate Proudhon's claims, and secondly, how can I avoid writing hindsight into Proudhon's thought? The literature on nineteenth-century international relations is vast and the literature on nationalism no less so - and I do not wish to claim to be an expert in either. My analysis is rather driven primarily by a first hand commentary on the interstate politics of the nineteenth century, and I have chosen to corroborate his analysis by those which seem to chime most closely to it. Thankfully, most standard histories of the period confirm Proudhon's analysis.

\footnotetext{
${ }^{12}$ Rudolf Rocker, who fled Germany for the US in 1936 to escape the Third Reich has argued that "[t]he brilliant Frenchman [Proudhon] had recognised clearly the moving principle of efforts at unity. Everything which he prophesied for the Italians has been made good to the very last letter. If Piscane and his friends believed that only in France could it happen that an entire nation would put itself in the hands of any adventurer who made great promises, and especially who gratified their thirst for glory, the example of Mussolini has since shown us that national-political unity prepared Italy for exactly the same sort of thing." Rocker [1998], p. 427.

13 Talmon [1952].
} 
As I will show, Proudhon, like many writers in contemporary international history, approaches the issue of nationalism from the perspective of the consolidation, and postRevolution re-legitimating, of state power, and the consequent disruption statist nationalism caused to the post-1815 European balance of power. He sees particular types of nationalism as constructed and expressed by conservative political leaders, socialist and democratic publicists and agitators alike. The key argument Proudhon made at the time was that the drive towards "national unity”, especially in Italy and Poland, but also throughout Europe, was a contradiction in terms and a pretext for bourgeois exploitation and state imperialism. He argued that the threat to European security caused by these movements was counter-revolutionary. This was quite a statement to make, and one that was roundly ridiculed at the time. We will gain some sense of why Proudhon's ideas were rejected here, but the fuller context will be made clearer in the two chapters to follow.

Proudhon's analysis largely supports John Breuilly's influential historical approach to the question of nationalism, which has shown that in the case of Germany, Italy and Poland, and to some extent France, “[n]ationalism was more important as a product than a cause of national unification."14 Furthermore, "nationalism is, above and beyond all else, about politics and that politics is about power. Power, in the modern world, is principally about control of the state." 15 Proudhon could see well enough that particular states used nationalist movements to their own ends, and that the revolutionary movements were being duped. Proudhon's critique approached the issue of the European balance of power through this lens. Showing Proudhon's anti-statist alternative to this process in chapter six ought to provide a much needed piece of socialist pre-history to this narrative, lost more or less since the day it was written. Finally, if Proudhon is as consistent as I claim he is, there ought to be symmetry between his international political theory, the direction in which he saw nineteenth-century international affairs developing, and the solutions he offered. If his analysis was correct, then surely there is something to be said for a reinvestigation of his solutions. By extension, there might also be good reason to call for

\footnotetext{
${ }^{14}$ Breuilly [1993], p. 96.

${ }^{15}$ Ibid., p. 1.
} 
a return to Proudhon's thought as such. It is my contention that there is such symmetry and this will be made clearer with each chapter of the thesis.

\section{Italy}

In this section I will show that Proudhon's analysis of Italian unification highlighted three things. First, nationality was a historical and cultural phenomenon that was rarely contiguous with a state. Secondly, imperialism and empire, by definition control of more than one nationality, was the norm. Third, Proudhon argued that this new nationalistinspired imperialism in Europe was likely to shatter the European balance of power. Moreover, based on his observations of the effects of the industrialisation of warfare in the Crimean and Lombardy campaigns, he feared that this new phase in the form of warfare would spell the end of the Revolutionary period and a consolidation of centralised state power. Proudhon's aim, contrary to popular belief, was to argue for stability in the European balance of power since he believed that instability spelt war. The reason for avoiding war was not one borne of pacifist concerns however. Proudhon argued that the combination of a nationalised and militarized state, and the unprecedented centralisation of power this combination suggested, not to mention the instability it would bring to the European balance of power, signalled the end of the potential emancipation of the working class and portended the oncoming of war. Proudhon's analysis began with Italy.

Proudhon's writings on Italy originally appeared as newspaper articles in the Belgian press in July 1862. They caused such outrage amongst Belgian nationalists and politicians that Proudhon's position as a French exile living in Brussels became untenable. In the first of the two articles that were later to form Fédération et l'Unité en Italie, Proudhon made the sarcastic observation that uniting Italy under the leadership of Victor Emmanuel was no less absurd than, and would probably lead to, Napoleon III annexing the Low Countries. Deliberately misinterpreted as implying a call for just such an annexation, the furore this caused, lead directly to his forced expulsion and must also 
have had a direct bearing on the popularity of the ensuing publication of the articles: twelve thousand copies were sold in France within a couple of months. ${ }^{16}$

In the introduction to this publication Proudhon set the record straight in the following manner:

Je ne veux pas de l'unité italienne, parce que cette unité n'est, à mes yeux, qu'une fantaisie italienne; parce qu'elle est contraire aux principes politiques, aux tendances de la civilisation, au droit des diverses nations de l'Italie; parce qu'elle ne pourrait s'établir qu'au moyen d’une dictature armée, au mépris des conditions géographiques et des traditions historiques; parce qu'en ajournant pour longtemps des aspirations libérales de l’Italie, elle porterait une grave atteinte au développement de la liberté en Europe; parce qu’enfin cette unité, oblige de créer, pour contraindre la divergence des populations, une force militaire redoutable, romprait au dehors l'équilibre établi, et provoquerait dans les États circonvoisins une agitation qui ne se terminerait que par le remaniement de la carte politique de l'Europe. C'est alors que, précisant ma pensée, j’ai indiqué l’incorporation de la Belgique dans l'Empire français comme devant être, selon toute probabilité, une des conséquences de ce remaniement. ${ }^{17}$

Here Proudhon argues that unification would be spurious, nationalism an illusion and it would take a dictatorship to enforce it. Moreover, it would spell the end of the liberalisation of Europe, and by this he means the end of the constitutional impulse sweeping the continent, by de-stabilising the balance of power. We need to explain why he has this alternative view and why no one at the time seemed to agree.

\footnotetext{
${ }^{16}$ Woodcock [1956], p. 247

${ }^{17}$ Ibid., pp. 74-75.
} 
To begin with, Proudhon concurred with Metternich that Italy was "une expression géographique à la disposition du plus fort”. 18 Italy, Proudhon argued, was a country that had a history of diverse tongues, traditions and institutions, no less culturally varied than geographically and ecologically diverse. Politically speaking, and following his friend the famous Italian historian Joseph Ferrari, he argued that the ideas that divided Italy were the same as those which had divided Europe since 1815: federalism vs. unity; republican constitutionalism vs. monarchy; revolution vs. conservatism; secularism vs. Catholicism; socialism vs. liberalism, and so on. ${ }^{19}$ Thus, because of the complexity of the issues, the 'Italian question' was the touchstone for most debates about the nature and future of nationalism and unity in Europe. Moreover, because the resolution to the Italian question could also provide a resolution to these epochal debates, Proudhon argued, the whole of Europe had an interest in the Italian question, and thus why it was such an important issue to resolve "diplomatiquement”. ${ }^{20}$ Unfortunately, Proudhon saw quite clearly that Napoleon III was an opportunist who was desperate to build his prestige and power at home and abroad, and was using nationalism to do so. He aimed to extend France to what he decided were its 'natural frontiers', and by so doing break up the 1815 settlement. Of the Italian protagonists, Victor Emmanuel, King of Piedmont, and his Prime Minister, Count Camillio Benso di Cavour, wanted control of the entire peninsula. It is now well documented that they achieved this through the systematic manipulation of nascent nationalist movements something which Proudhon saw clearly.

The story of Franco-Piedmontese adventurism in the Italian peninsula begins in 1854 with Piedmontese entry into the Crimean War on the side of the Anglo-French axis. The rather insignificant part played by Piedmont nevertheless bore disproportionately ripe fruit, since by taking part Cavour secured himself a seat at the Congress of Paris at the conclusion of the conflict in 1856. Here, the map of Europe, the middle and near east was redrawn and through diplomatic means Piedmont gained international status beyond what

\footnotetext{
${ }^{18}$ Proudhon [1998], p. 214. cf. Smith [1959], p. 1. Woodcock notes that Metternich once quipped that Proudhon was “an illegitimate child of the Encyclopaedia”. Woodcock [1956], p. 204. What Woodcock sees as the "oblique truth" of this remark will become clearer when we approach Proudhon's theory of justice in chapter four.

${ }^{19}$ Proudhon's correspondence with Ferrari is reproduced and discussed in Dolléans [1948].

${ }^{20}$ Proudhon [1863], p. 217.
} 
would normally have been thought of such a small kingdom in what was generally considered a backwater of Europe. Cavour's aim was to use Italian involvement in the Crimea to draw attention to 'the problems' in the Italian peninsula - mainly the unwanted rule of the Austrians in the north east.

Using his new-found status to his advantage, two years later, in July 1858, Cavour met with Napoleon III in secret at Plombières, to conclude an alliance against Austria that would secure French support for Italian unification under the crown of Piedmont. ${ }^{21}$ In return for the Duchies of Savoy and Nice, which Napoleon believed constituted the final pieces of his southern 'natural frontier', and a new French state in central Italy that would restore Napoleonic title to Rome (this claim later provoking the Catholics into the only anti-war movement in France), ${ }^{22}$ Cavour persuaded Napoleon to back his own imperial design in the peninsula. The "chauvins" on the French right wanted France restored to her 1804 boundaries, which meant annexing Belgium and the whole of the Rhine, and to the south both Piedmont and Lombardy. ${ }^{23}$ Cavour avoided this, saving his own state of course, and it was agreed that post-unification Italy would be a confederation of four states: Piedmont in control of what was previously Lombardy and Venetia, Parma and Modena. The Kingdom of Naples would remain independent and Louis Napoleon would take control of a puppet Papal state. ${ }^{24}$

Unfortunately for Louis-Napoleon and Cavour, and as contemporary historians have noted, despite the absence of any constitutional form of government, Austrian rule in northern Italy was relatively benign, with few egregious abuses of power and privilege. The people were more or less satisfied with the Emperor, and were granted de facto national autonomy throughout the empire. Where further liberties were actively championed state force quickly subdued any liberalising trends, but this anti-modernism was mirrored in the conservative attitudes of the rural populations. ${ }^{25}$

\footnotetext{
${ }^{21}$ Like others, Proudhon was aware of this meeting but not of its details. See Proudhon [1863], p. 127.

${ }^{22}$ Haubtmann [1988], p. 161.

${ }^{23}$ Proudhon [1863], p. 146.

${ }^{24}$ Rich [1970], p. 73.

${ }^{25}$ Sked [1990], p. 144.
} 
The left campaigned strongly against the Austro-Hungarian Empire precisely because of Metternich's refusal to countenance the liberalisation of the empire, and his persistent rejection of (minimal) claims for regional autonomy. On the other hand the political right and other European states hated the regional power of the empire. Proudhon, by contrast, was rather ambivalent, remarking that it was "de mode" to denounce Austria, but any desire to abolish the Empire must take into account, he argued, the fact that something would have to take its place and it was not clear that the alternatives were much better. ${ }^{26}$ He also rather cannily observed, based on his analysis of European history, that the desire to constitutionalise the Austrian Empire, would actually cement the 1815 treaties rather than abolish them, by deepening the international equilibrium through entrenching it socially.

Thus, since there were no obvious military or diplomatic grounds for going to war with Austria, Austria was effectively tricked into hostilities by Cavour and, as agreed, France immediately came to Piedmont's aid. As A. J. P. Taylor argued, the decision to go to war was "incompatible with any known system of international morality."27 It seems we can only concur with Proudhon that the reason for Cavour's actions in Italy was imperialism; ${ }^{28}$ it was "une crime” he said, "mais faites comprendre cela aux chauvins!"29

The ensuing post-war treaty of Villafranca (1859) is a particularly important milestone in Italian history for Proudhon. The armistice and ensuing treaty between Napoleon III and Franz Joseph of Austria would have been based on the division and federation of Italy into four. Lombardy was to be ceded to Napoleon III and then passed on to Cavour and Piedmont. Secondly, the creation of the state of Tuscany and Modena and the autonomous Papal state, would have balanced Venice, which would become a free state

\footnotetext{
${ }^{26}$ Proudhon [1868], pp. 223-225.

${ }^{27}$ Taylor [1954], pp. 111-112. An indication of the modest degree of hyperbole Cavour employed to persuade the British and the French of the need to check a largely concocted Austrian expansionism can be found in Kertesz [1968], pp. 187-189.

${ }^{28}$ Proudhon [1867], p. 110.

${ }^{29}$ Cited in Haubtmann [1988b], p. 161 As Sked has pointed out, it was the threat of financial ruin and defeat at the hands of Piedmont and France that ultimately forced Franz Joseph to accept constitutionalism in the 1860s.
} 
in this Italian confederation but remain subject to the crown of the Emperor of Austria. ${ }^{30}$ This concession to Austria was purely expedient on Louis Napoleon's part since he realised his power in the region was waning and without a counterbalance to Piedmont things could get tricky on his southern border - as Proudhon had argued they would. ${ }^{31}$

The idea of the Confederation was never realised. Moreover, the treaty itself has received relatively little critical attention by scholars of European history, perhaps because it is viewed as a minor incident in a broader narrative of French and Piedmontese opportunism in the peninsula. For Proudhon, on the other hand, it represented Italy's last chance to avoid certain ruin. "L’idée fondamentale du traité de Villafranca” was, he argued,

la fédération de l'Italie, sous la protection de Napoléon III devait être acclamée par tous les Italiens comme la Bonne Nouvelle: le machiavélisme italien, joint à l'incompréhensible politique de journaux français, en ont décidé autrement. Plus que sur tout autre, la responsabilité en incombe à Mazzini. $^{32}$

I will discuss Mazzini's role below and Proudhon's assessment is perhaps a little unfair, however, what is clear to modern historians is that Napoleon III effectively reneged on his deal with Cavour. He relinquished his claim to Nice and Savoy since he could not give Venice to Piedmont. This was because, despite heavy losses, Austria had been surprisingly more effective than predicted at the battles of Solferino and Magenta, denying Piedmont and France that decisive victory.

Seeing his chance beginning to slip away, Cavour prompted nationalist riots against Austria in the central Italian states, and then plebiscites for Piedmontese rule, and it became clear to Napoleon that he would soon lose control of Italy if the Italian nationalist

\footnotetext{
${ }^{30}$ Kertesz [1968], p. 190.

${ }^{31}$ Proudhon [1862], p. 13. Proudhon notes here that a united Italy would not want a strengthened Imperial France on her northern borders, or vice versa, and that this would likely spark a regional arms race.

${ }^{32}$ Ibid., p. 30. cf., Taylor [1954], p. 115.
} 
clamour for Venice turned into a likely more militant anti-French attitude. ${ }^{33}$ Losing control of northern Italy to a country under the control of Piedmont, as Proudhon had argued, would have been a serious problem in terms of French military security. ${ }^{34}$ Of course, by this point it was too late and events were largely beyond the control of any one group, ${ }^{35}$ and Piedmontese opportunism and cunning were to reap the most rewards. If we value political skulduggery, imperialism and the blatant disregard for any power or people but one's own, Cavour perhaps deserves his reputation as the most skilful diplomat of the nineteenth-century.

But Cavour, it should be noted, was no Italian nationalist. Like most of the upper class of nineteenth century Europe, French was his formal and mother tongue and his Italian was far from perfect. He was an innovator, irreligious and opportunistic, but his leadership in Piedmont effectively transformed the Kingdom into the leading 'indigenous' power on the Peninsula. He was vehemently anti-socialist but a radical reformer. Indeed, he viewed the latter as a bulwark against socialism for as long as authority remained with the ruling classes and, despite his liberal protestations, with him in particular. ${ }^{36}$

Turning next to Mazzini, and while it is difficult to give a balanced account of so prolific a writer in such a short space, it is fair to say that he was a romantic utopian. Driven by contrived nationalist and unitarian ideals, and inspired by the ideas of Herder and Schlegel, he viewed the role of literature and culture as one of galvanising a sense of cohesiveness in a nation - however one chose to define that nation. ${ }^{37}$ However, Mazzini was critical of Schlegel's idealisation of the medieval period, and, rather than preserve Italy's regional and cultural particularities, he sought the evolution of Italy into a higher, unified entity thus realising the cultural and romantic aspirations of the Italian literati. ${ }^{38}$ “This young Italy” Mazzini argued, must be "unitary;”

\footnotetext{
${ }^{33}$ Rich [1970], pp. 74-75.

${ }^{34}$ Proudhon [1867], pp. 126-133.

${ }^{35}$ Ibid., pp. 136-137.

${ }^{36}$ Smith [1959], pp. 20-25.

${ }^{37}$ Haddock [1999], p. 316.

${ }^{38}$ Ibid., p. 317.
} 
For without unity there is no real nation, because without unity there is no power, and Italy, surrounded by unitary nations, which are strong and jealous, must, above all, be powerful. Federalism would reduce it to the powerless condition of Switzerland, and under stress of necessity it would fall under the influence of one or another of the neighbouring nations. Federalism would give new life to the rivalries of different localities, which today are quenched and would lead Italy back to the Middle Ages ... Seeking the destruction of the unity of the great Italian family, federalism would render utterly vain that mission that Italy is called to fulfil for humanity. ${ }^{39}$

Here we can see how Italy's future is cast as a harbinger of Europe's future and, while Proudhon doesn't engage with the underlying teleological philosophy of Mazzini's history-writing, two things caused him particular concern. The first was his consequentialism, the second his desire to homogenise Italy under one conception particularly his own - of what a united Italy ought to be.

While he was fully aware of Cavour's Machiavellianism, which earlier in the struggle for Italian unity had driven Mazzini and his co-conspirators underground as the Carbonari secret societies, of the type later used by Bakunin, this did not stop Mazzini from aligning with Cavour later. As modern historians have shown, this occurred despite the fact that Cavour wanted to hang Mazzini in $1860 .^{40}$ But Mazzini did share one thing with Cavour and Napoleon: he loathed socialism as a social doctrine. It was this which the latter two used to their advantage.

Proudhon's moralism comes clearly to the fore in his critique of Mazzini. Mazzini's willingness to sacrifice his early republicanism and side with King Victor-Emmanuel in the interests of Italian unity brought forth real vitriol from Proudhon. "Pour un républicaine sérieux, c’eût été l’apostasie en échange d’une utopie; pour Mazzini, c'était

\footnotetext{
${ }^{39}$ Cited in Rocker [1998], p. 425.

${ }^{40}$ Breuilly [1993], p. 112.
} 
un acte de la plus haute vertu. ${ }^{41}$ Proudhon accuses Mazzini of two things: first, of having lacked any foresight regarding the consequences of his siding with Piedmont, second, of pursuing a political project that was flawed in principle because of its morally questionable opportunism or consequentialism. ${ }^{42}$

Proudhon also saw that Mazzini had no interest in the economic and social problems of Italy and argued that this ought to make him the enemy, not the champion, of the Republican cause in France. ${ }^{43}$ Nevertheless, French democrats were seemingly blind to this fact and, driven by their own ideas about French Étatisme (the focus of the following chapter), supported the ideals of national unity espoused by Louis Napoleon, Mazzini and Cavour at whatever cost. Proudhon's analysis led him to believe that the champion of national unity was, in fact, also the executioner of nationalities. "Le premier effet de la centralisation" he argued,

est de faire disparaître, dans les diverses localités d'un pays, toute espèce de caractère indigène; tandis qu'on s'imagine par ce moyen exalter dans la masse la vie politique, on la détruit dans ses parties constitutives et jusque dans ses éléments. Un État de 26 millions d’âmes, comme serait l’Italie, est un État dans lequel toutes les libertés provinciales et municipales sont confisquées au profit d'une puissance supérieur, qui est le gouvernement. ${ }^{44}$

This conception of Italian politics was driven by his friendship with Ferrari and the latter's lectures on the subject, and Proudhon's analysis of the work of the eminent French historian Jules Michelet, with whom he had corresponded between 1838-1841. Michelet argued that civic laws emerge from the cultural and historical particularities of a geographic region and the people but could not be imposed from above. Michelet supported the Irish, Polish and Italian nationalist movements, because they attempted to

\footnotetext{
${ }^{41}$ Proudhon [1962], p. 13.

42 Ibid., p. 12.

${ }^{43}$ Pflanze has argued that the national question in Germany and Italy was a distraction that blinded most revolutionaries to the plight of the people. This ignorance of social concerns meant there was little popular support for the Risorgimento, and in Germany pushed the lower classes away from liberal nationalism and over to Marxism. Pflanze [1966], p. 132.

${ }^{44}$ Proudhon [1862], p. 25.
} 
generate this groundswell that could have led to political autonomy. Proudhon disagreed, not because he was against nationalities, but because he foresaw only negative consequences in the rise of nationalism on the European balance of power.

Proudhon argued that if the principle of nationality meant anything at all in Italy, it had to be as applicable to the historical localities built around the ancient city states as it was to the larger agglomerations. Moreover, destroying these collective expressions of regional autonomy is immoral. The practicalities of governing such diverse communities would also, Proudhon argued, demand the kind of centralisation and force that suppresses the very liberties that Mazzini claimed to champion - those of (diverse) Italians. "Et qui profite de ce régime d’unité? Le peuple? Non, les classes supérieures.” He continued that “[l]'unité aujourd'hui et depuis 1815, c'est tout simplement une forme d'exploitation bourgeoise sous la protection des baïonnettes.” ${ }^{45}$ In sum, all Mazzini would achieve with his so-called republicanism would be to "inoculate” Italy with despotism.

Proudhon's opinion of Mazzini was formed in the months running up to July 1862. By September Proudhon had published his second piece on the unitarist project in Italy, this time focusing on the machinations of Garibaldi and his exploitation by Cavour and Victor-Emmanuelle. At this time Garibaldi was leading the charge against the King of Naples from his base in Sicily, which Garibaldi had 'conquered' with little effort and with even less design.

Garibaldi's moral rectitude, an area in which Mazzini was lacking, was something Proudhon praised without hesitation. But he criticised his tactics, aims and actions, and pitied his exploitation by Cavour and Napoleon III. He had something of "César et du Washington” about him Proudhon argued, ${ }^{46}$ but it was the unintended consequences of Garibaldi's actions that incensed Proudhon the most. Garibaldi's lack of foresight, his lack of any guiding principles, and the fact that his political awareness was further clouded by his missionary zeal for unity, seemed always to thwart his plans.

\footnotetext{
${ }^{45}$ Ibid., pp. 27, 28.

${ }^{46}$ Proudhon [1967], p. 143
} 
Louis Napoleon's aim in Italy was to establish his dynastic dominance in a federal grouping of the principle states of the peninsula. After Solferino this became impossible. It also became clear to all Italian nationalists, and Louis Napoleon's domestic support in France, that he was less interested in Italian Unity and the cause of its peoples than originally presumed. This fact was not lost on either Garibaldi or Mazzini who both then campaigned against France and used her ambitions in the peninsula as the pretext for their own. Nevertheless, France and Piedmont persisted in their mutual manipulation of the nationalist cause for their own ends - France to assure that a unified Italy did not upset the regional balance of power and could assure her natural frontiers, and Piedmont to assure what was ultimately to be the exact opposite.

Garibaldi's nationalist campaign and his successes in Sicily and Naples were seen as a danger to both these ambitions. His quasi-leftist and anti-monarchist ambitions were a threat to Cavour who skilfully headed off any further advances by Garibaldi in the peninsula by provoking unrest in the kingdoms north of Naples and moving in to quash, and take advantage, before Garibaldi ignited a social revolution. ${ }^{47}$ Garibaldi then became a menace to French ambitions when his march north threatened the safety and Papal autonomy of Rome, a state he had strangely defended in $1849 .{ }^{48}$ Unfortunately, liberating Rome from the French and expelling them from the peninsula in the name of national unity was a personal ambition which had little resonance in the southern states from which he derived his support. In fact Garibaldi had no revolutionary plan, and after his resounding victories in Sicily a chance cry of "Rome or death" from the crowd became "a war cry and a policy” and antagonised Piedmont still further. ${ }^{49}$

This cry from a crowd may give the impression that the people were wholeheartedly behind the unification of Italy. But the reality was somewhat more complicated and revolved mainly around the desire to expropriate the church. Dennis Mack Smith argues that it was largely the professional classes, particularly lawyers, and students who marched the quickest step. The vast majority had been largely unimpressed by

\footnotetext{
${ }^{47}$ Smith, [1959], p. 63.

${ }^{48}$ Proudhon [1862], p. 40.

${ }^{49}$ Smith [1959], p. 63.
} 
insurrections and political independence and craved their regional independence as much as they accused their neighbours of conspiring against them. ${ }^{50}$ Breuilly recounts the other amusing anecdote that when Garibaldi let out the cry "Viva Italia!" the crowd thought he was referring to Victor Emmanuel's wife. ${ }^{51}$

Proudhon argues that the Italian revolutionaries, indeed the European left as a whole, were naïve in terms of their understanding of the nature of state power in Europe. He argued that "du moment qu'ils [Garibaldi et Mazzini] refusaient de compter avec les puissances établies et avec les nécessités du siècle, pour se livrer à leur emportement démagogique, la patrie était perdue pour eux”. ${ }^{52}$ And it was. With all the instruments of state power at his disposal Cavour, managed to skilfully outwit Garibaldi and keep Britain on side by campaigning against the power of Austria and the red menace.

Proudhon thus saw that "[l]a cause du prolétariat et celle de l'équilibre européen sont solidaires; toutes deux protestent avec un égale énergie contre l'unité et en faveur du système fédératif." ${ }^{53}$ But for Proudhon to talk of retaining the European balance of power in the early 1860s was to be viewed by the vast majority to be in support of Metternich, "l’homme le plus haï du XIXe siècle”. ${ }^{4}$ Therefore Proudhon's reactionary credentials seemed to grow with each new utterance. But his aim was rather to stabilise European political relations through federalism following the Swiss example I will discuss below, and by supplementing it with a socialist, mutualist agro-industrial federation - the focus of the final chapter of the thesis.

Ironically, at the 1867 conference of the League for Unity and Peace that met in Geneva under the presidency of Garibaldi, a motion was passed that took the freedom of all nationalities and their federation as the only true and possible base for the peace of Europe. ${ }^{55}$ The horse had bolted by this time. The French press and democratic left who

\footnotetext{
${ }^{50}$ Smith [1959], p. 12.

${ }^{51}$ Breuilly [1993], p. 113.

${ }^{52}$ Proudhon [1867], p. 141.

${ }^{53}$ Ibid., p. 147.

${ }^{54}$ Amoudruz [1945], p. 95.

${ }^{55}$ Darriulat [2001], p. 249.
} 
campaigned against federalism and in support of Napoleon, Cavour, Garibaldi and Mazzini. The press “n’a foi qu’aux expédients, à ce qu'il nomme, avec ses vieux ennemis les Jacobins, politique d'action."56 The problem with the press therefore, as with Mazzini, was that they were acting according to flawed political principles - namely unity, nationalism and statism and pushing an ends-based logic that totally ignored the political realities of the period.

The French press railed against the temporal power of the Pope and in favour of the plight of Piedmont and the evils of Austrian rule in the peninsula. This earned certain individuals decoration from Victor Emmanuelle, despite, as I will show in the following chapter, also being in favour of French hegemony in Europe and championing her missionary purpose to which Italian unity was arguably antithetical. ${ }^{57}$ While the details of Proudhon's critique of the press ought to be of significant interest to historians of the period, like so much of his analysis, it dates quickly. It nevertheless shows how a nationalistic public opinion was generated by the press as a justification of Italian unification, much in the same way as Mussolini would later encourage histories that accorded with his particular line on Italian history and unity. ${ }^{58}$

Proudhon asked the following of socialist and democrat opinion in France: why would monarchical and imperialistic states become champions of the socialist cause in Italy, Poland or Austria, when this had so clearly failed to materialise in France? Why was it that the children of the Revolution, those who were taught to denounce what Proudhon called industrial feudalism, were helping states to realise precisely this in Italy ${ }^{59}$ On the issue of the Papacy, the idea expounded in La Presse was to abolish all papal and religious privileges (education, property, etc) in Italy once unity had been established under the regional hegemony of Louis Napoleon. But Proudhon argued that Empire and monarchy without religion to mollify it, was tyranny in the extreme. Resurrecting the ghost of Robespierre, and arguing against the leftist tendency to disregard the power of

\footnotetext{
${ }^{56}$ Proudhon [1867], p. 182.

${ }^{57}$ Ibid., pp. 1183-185.

${ }^{58}$ Smith [1959], p. vi.

${ }^{59}$ Proudhon [1867], p. 172.
} 
ideas and morality in politics, he argues that, with the pastoral role of the church embedded in the state, despotism of the worst variety would surely follow. ${ }^{60}$

The press was also an important window onto battlefield conditions and the deployment of field reporters for the first time in history made the campaigns of the Crimea and Lombardy incredibly immediate for the public of the day. Proudhon here cited from The Times' coverage of the Lombardy campaigns and asked whether the new artillery used there was in any way less discriminate than poisoning the water of the enemy - outlawed under international law. To put five or six kilometers between the imprecise shot and the vaguely seen target ought to have been seen to be as indiscriminate as poisoning and, Proudhon continued, shrapnel kills far more than were ever killed during hand-to-hand combat. $^{61}$

The immediacy of this coverage was made all the more dramatic by stories of how by the mid-nineteenth century, modern artillery, rifling, the revolver, and other such revolutionary instruments of war, had begun to reduce war to "abatis réciproque”. 62 Watching this process unfurl, Proudhon began to argue that "le pérféctionnement des armes, à rendre la rencontre des masses impossibles."63 Moreover, arming the French military with pistols was a sign of cowardice, irrespective of its necessity. ${ }^{64}$

Quand les armes seront telles que le nombre et la discipline, aussi bien que le courage, ne seront plus de rien à la guerre, adieu le règne des majorités, adieu le suffrage universel, adieu l'empire, adieu la république, adieu toute forme de gouvernement. Le pouvoir est aux plus scélérats. ${ }^{65}$

But, with interests being the rising creed at this time, and utility the guiding (im)morality in war, Proudhon lamented the possibility that when interests and ideals come into

\footnotetext{
${ }^{60}$ Ibid., p. 182.

${ }^{61}$ We will return to the notion of the laws of war in relation to war's industrialization in chapter five.

${ }^{62}$ Proudhon [1998a], p. 282.

63 Ibid., p. 283.

${ }^{64}$ Ibid., pp. 255-257.

${ }^{65}$ Ibid., p. 257.
} 
conflict, interests will tend to "fouler aux pieds toute moralité et tout idéal." Seeing this process as largely inevitable, Proudhon prayed: "[a]h! de grâce, gardons-nous d'introduire l'utilitarisme dans la guerre, pas plus que dans la morale."66 God wasn't listening.

I have tried to illustrate a number of things in this first section. First, European political relations were experiencing seismic shifts during this period. The nation state was formed by exploiting notions of nationality in the interests of state power. It is thus important to keep the notion of the state separate from that of the nation precisely because the two were not the same thing. The British, Ottoman, French, and Austro-Hungarian empires were clearly not national states. It was their collapse in the name of the nation state that produced world war. As I will argue in chapter six, Proudhon's call for the entrenching and republicanising of all states as the best way to check their power in the short term was clearly not a chauvinist position. The autocratic states of Europe were far from what Proudhon advocated, and it is hard to comprehend the rejection of Proudhon's republicanism from our contemporary vantage point.

Finally, the aggravation of the European balance of power through the unification of Italy was the express policy of Napoleon III. But became one which he could not control once he set it in motion. Proudhon argued that it was the principles that governed these political acts that were flawed - principles of statism and unity that I will discuss in the following two chapters - and because of the lack of a clear understanding of the nature of the international system and its role in securing order, disaster would inevitably follow. The industrialisation of the military and the role of the press in supporting Louis Napoleon's championing of the cause of European nationalism were equally dangerous, and Proudhon's approach was sensitive to the complexity and irreducibility of European politics - a sensitivity which was utterly tangential to the political culture of his time.

${ }^{66}$ Ibid., p. 289. 


\section{Poland}

I now turn to Proudhon's analysis of the 'Polish question'. This was no less serious than the Italian question, and for Proudhon represented the key to "la paix du monde". 67 Nevertheless, the particularities of Polish history and society generated radically different solutions to those which he suggested for Italy. In the case of Italy, Proudhon's objection to the project of national unity was that it would swamp all the diverse traditions and localities, and upset the regional balance of power to the detriment of international order. Proudhon's objection to Polish unity were that there was no such indigenous community that could constitute a nation nor a state in the first place. Attempts to create one out of nothing were, he argued misguided. Given the entrenchment of the institution of the nobility and their fickle alliances with regional power blocks, uniting Poland would present any of these power blocks with too great a temptation to swallow her up. Moreover, unification would not advance the cause of the predominant serf population. Here, again, it is his concern to preserve the European balance of power that occupies his mind the most. I will show that he believed that it was only if such a balance can be preserved that social progress could continue in Poland as in the rest of Europe. The case of Poland also shows just how contrived nationalist projects were in the mid-nineteenth century.

Proudhon's approach to the Polish question was far more historical and detailed than his polemical opposition to Italian nationalism, and was the outcome of a two-year, 900 page analysis that was eventually published only in fragments. ${ }^{68}$ Amoudruz cites Proudhon's belief that his readers would not have understood it as the principle reason for deciding not to publish it, ${ }^{69}$ while Woodcock claims that Proudhon did not want his critique of Polish nationalism to stand in the way of the ambitions of his friends, Herzen, Bakunin and others, who in 1861 and 1863 played leading roles in the ultimately unsuccessful

\footnotetext{
${ }^{67}$ Proudhon [1867], p. 286.

${ }^{68}$ Proudhon [c. 1863].

${ }^{69}$ Amoudruz [1945], p. 37.
} 
Polish insurrections. ${ }^{70}$ Bakunin, perhaps the most notorious romantic revolutionary of the period, taking more liberally from the culturalist tradition of Herder and the young Hegelians to avoid the institutionalism of the French civic tradition, was particularly disappointed with Proudhon's opposition to Polish nationalism, but once we understand Proudhon's motives, with the added benefit of hindsight, we can pay testament to his foresight.

The key question at that time was whether Poland should be restored to her pre-1773 borders and unified. The driving force was a new Polish nationalism. Again, the issue was whether the revolutionaries had a right to call for national unity to which Proudhon replied unequivocally: "Non. Les Polonais ne sont pas en droit."71 Proudhon argues that the division of Poland was "commandé par la nécessité” and was vital to European order, peace and progress. $^{72}$

Even by nineteenth-century standards, the people of Poland, i.e., everyone but the nobles, were in a notoriously underprivileged state and there was no bourgeoisie of any note. Poland was completely dominated by its nobility. Historically the nobility had fought amongst themselves for seigniorial rights and routinely aligned with the three regional powers of Prussia, Russia and Austria according to their own interests. These nobles, Proudhon argued, rarely governed anything of any note but simply reigned over a community of serfs that sustained them economically. Proudhon remarked that "[s]'il est un coin sur le globe ou jamais il ait été vrai de dire, non au point de vue d’une critique transcendent, mais à celui de la pratique positive, que la propriété est le vol, c’est en Pologne."73

The nobility periodically wrote and devised constitutions that were not enacted, and generally did nothing to improve the lot of the people. This, Proudhon argued is the opposite of what happened in other countries. Referring to Britain in an

\footnotetext{
${ }^{70}$ Woodcock [1956], p. 239

${ }^{71}$ Proudhon [1867], p. 289.

${ }^{72}$ Ibid.

${ }^{73}$ Proudhon [1867], p. 302.
} 
uncharacteristically generous way, Proudhon argues that here the upper classes, particularly the emergent bourgeoisie, raised the moral and civic consciousness of the people through organising social power and enacting and defending secular principles of justice against the noble class. In Poland the church and nobility did nothing of the sort and thus the position of the people remained abject. In other words, there were no intermediary social and political cleavages in Poland that through their mutual antagonism could generate an organic civic constitution (precisely why Proudhon thought it would will be made clearer in chapters five and six). Therefore, Proudhon argued that Poland ought to remain partitioned until a middle class could arise to temper the stark injustices in Polish society. ${ }^{74}$

The eighteenth-century history of Poland is the key to understanding why and how it was continually partitioned. With a weak (if not puppet) royalty sitting at the head of a selfinterested nobility, it was relatively simple for the major European powers to take control and claim the country for themselves - as was the case with the abdication of Stanislas and the ensuing machinations of Prussia, France and Austria. With no domestic powers to root the nobility in their own country, zones of influence were easily carved up between the main regional powers and they became a major cause of European conflagration. ${ }^{75}$ The prize of Polish lands was too much for its neighbours to resist, and with such little internal organic connection between people and state, it was all too simple to take it.

Proudhon argued that the partition of Poland was thus central to European security and peace. It was also progressive, in relation to the animation of Polish civil society. For example, Catherine II of Russia had proposed the creation of a new middle class by reforming the lower nobility and developing the peasantry into a commercial force by 'emancipating' them. The nobility denounced both Catherine and her plans and claimed it to be a plot against the existence of Poland itself - which to a large degree it was if we consider Poland at this time as nothing more than a collection of nobles. Denounce it they

\footnotetext{
${ }^{74}$ Proudhon [1998], p. 175.

${ }^{75}$ Proudhon [1867], p. 298.
} 
did and "[d]e ce moment" Proudhon argued, "tout fut perdu". ${ }^{76}$ The first two divisions of Poland can thus be explained by the nobility's unmediated "hatred" of the serfs, preferring the partition of Poland to their emancipation in each case. Thankfully, Proudhon argued, this participation actually helped the serfs “réspirer”, giving life to their political aspirations as a social class. The congress of Vienna and the age of constitutions it ushered into Europe, despite retaining the partition of Poland, nevertheless gave civic and constitutional impetus to Polish political life.

It was for these reasons that the idea of Polish nationalism was a misnomer for Proudhon. He argued that since there was no organic link between the institution of the nobility and the population; since the population were an undifferentiated mass who were utterly disenfranchised; and because there were no institutions to link the people to one another and thus check the nobility, there was no way in which the people could come to govern themselves. Finally, since there was no nation as such, the championing of it was nonsensical. Since nationalism ought at least to be about self-government and autonomy of a nation, and since the people had not the means to realise it, nor inclination to believe in it, any plea for Polish nationalism would simply entrench the power of the nobility without redressing the issue of their allegiances. Polish nationalism of the variety advocated by the vast majority of socialists, a nationalism tied to a spurious conception of confraternity and unity, was an unsophisticated panacea for a critically complex reality. As such, Proudhon would not sacrifice the benefits of a European peace, predicated upon the strategic partitioning of Poland, ${ }^{77}$ and the European balance of power, for the sake of an aristocratic and minority left wing revolutionary-led fight for autonomy and unity. ${ }^{78}$

\footnotetext{
${ }^{76}$ Ibid., p. 299. Standard misconceptions of Proudhon's thought might lead one to believe that this is an odd approach to the issue of Poland and class relations, and some might rightly ignore Proudhon from here on in. But we should reserve judgement until we understand his social theory and his philosophy of history a little better. Here I simply want to outline his practical ideas as an introduction to his theory.

${ }^{77}$ Proudhon argued that “Le peuple n'a commencé à connaître la liberté que depuis le démembrement”. Ibid., cited p. 85. Proudhon saw Russian influence in Poland as essentially enlightening and often referred to the emancipation of the serfs as further proof of his position. He was criticised by Carr, amongst others, for an overzealous praise of the Russians - the arch Monarchs of European politics. cf., Proudhon [1998], pp. 176-178.

${ }^{78}$ Cf. Amoudruz [1945], p. 77.
} 
If there were any cause for Polish nationalism it should be based, he argued in 1861, upon a European conception of pan-Slavism tied to a restoration of Slavic rights in Russia. This, he argued, would begin a process of realising a cultural and historical foundation upon which to build a fight for civic political participation protected within the overarching structure of the 1815 balance of power. Furthermore, Proudhon argued that Russia should (and perhaps naively thought they would) take the initiative, much as Alexander II had done at home in 1861, in emancipating the serfs of Poland. He also argued that by suppressing Polish revolts in 1831, the Imperial Russia began to galvanise a distinctly Polish nationality, martyrs for the homeland, but paradoxically when revolutionaries rose again in Austrian controlled Galicia in 1846 the peasants massacred them. ${ }^{79}$ This was testament to the relationship between the people and the empire in this region, a relationship which no matter how internally contradictory from a revolutionary standpoint, the revolutionaries simply chose to ignore.

For Proudhon it must have seemed ironic that he would advocate Russian influence in the region as a positive force, and to have seen campaigning against it as evidence of the idea of the indigenous nation it had 'produced'. This was not, however, evidence in favour of restoring Poland or championing Russian autocracy. But to remove Russian influence, despite recognising its barbarous nature, ${ }^{80}$ would cause Poland to regress back to the rule of the nobility. Moreover, a united Poland would be one giant trophy and a country that could be taken by any of her neighbours, and without a home-grown opposition, thus destroying the European balance of power. In sum, the time simply was not right for the restoration of Poland, nor was Polish nationalism either in Poland's nor in Europe's interests. As I will show, Proudhon argued that 1815 marked the end of the era of agglomeration of states and the beginning, through constitutionalism, of their disaggregating. The revolutionaries of Poland, in Proudhon's final analysis, simply wanted to change the conditions of rule in their country, for their own benefit. The consequences of this plan were too dangerous to be considered and he argued,

\footnotetext{
79 Proudhon [1867], p. 306.

${ }^{80}$ Ibid.
} 
systematically, against Polish nationalism. At his most extreme, he even asked of Poland: “[e]st-il [...] si malheureux de mourir?”81

Of course, all of this was totally antithetical to the arguments of the Polish nationalists, and Russian revolutionaries, who saw Russia as nothing but an absolutist occupying power, and could not disagree with Proudhon more. Yet, as Davis has argued,

The strength of the Insurrectionary Tradition [in Poland ...] bore no relation to the numbers of its adherents or to the outcome of its political programme. It reflected not the support of the masses, but the intense dedication of its devotees, whose obstinate temper, conspiratorial habits, and unfailing guardianship of the Romantic approach to Literature and History was effectively transmitted from generation to generation. ${ }^{82}$

Tragically, attempts at Polish nationhood in the century leading up to the revival of the Kingdom of Poland by Germany in 1916 "mocked the intelligence of those it sought to satisfy." 33 Moreover, "[i]n the nineteenth century, the Poles had been faced with a life of deprivation. In the twentieth century, they were faced with extinction.”84 The desire and drive for a Polish nation undermined the regional balance of power. This is not to say that nationalism and regional self-government were always bad for Proudhon - quite the opposite, as the example of Italy shows. But what was most important was to understand what are nominally domestic politics within the structuring and stabilising forces of the 'international'. Without this awareness, Proudhon's analysis suggests, revolutionary action was doomed to failure. Proudhon concludes that despite their differing situations, both the Italian question and the Polish question ought to have been resolved by the principle of federation that he outlines in detail and which I will discuss in chapter six.

\footnotetext{
${ }^{81}$ Ibid., p. 314.

${ }^{82}$ Davies [1981], p. 41.

${ }^{83}$ Davis [1981], p. 6.

${ }^{84}$ Ibid., p. 80.
} 
He says "Je suis parfaitement convaincu, par exemple, que la question polonaise ne peut pas se résoudre autrement que la question italienne, c'est-à-dire par la fédération”. ${ }^{3}$

\section{The Rhine Border}

To recap, Italian federalism was portrayed by Proudhon as able to respect indigenous particularity and resist the imperialism of neighbouring states. In the case of Poland eventual federation would stabilise the European balance of power but could not create a nation out of thin air. The question of the Rhine, on the other hand, set out in detail in France et Rhin (1867), concerned the liberty of European peoples as such. Again, the core issue was the protection of the European balance of power. Proudhon believed that the Rhine states constituted an important buffer between France and Prussia and the states to the north. Proudhon argued that it was defended by the Holy Alliance in 1815 because it represented the key to the liberty of nations from the imperialism of Napoleon. However, this was by no means either the beginning or the end of the matter for Proudhon.

In 1863 Proudhon decided to go for a walk along the banks of the Rhine to see for himself what was natural about it as a border. He argued that far from dividing people, given the similarity of customs, mores and language, the Rhine border actually formed the most obvious way of uniting them. ${ }^{86}$ The river united people through trade, similar dialects were spoken on both sides and habits and customs were also fairly similar. It may have been a border between states, and in this sense "l’idée d'une frontière donnée par la nature a le mérite, assurément très considérable, de faire sortire la politique internationale de l'arbitraire où elle aime à se tenir”, ${ }^{87}$ but it most certainly was not a border between nations.

\footnotetext{
${ }^{85}$ Proudhon [1867], p. 163.

${ }^{86}$ Woodcock [1956], p. 238.

${ }^{87}$ Proudhon [1868], p. 11.
} 
In this unpublished work Proudhon argued for a philosophically realist, historical and "ethnographique" ${ }^{88}$ understanding of the distribution of peoples and nations that was largely derived from Montesquieu but whose work had infused the whole of French political literature by this point. He is clear that while the state is often, though not always, coterminous with a nation that sustains it, rising and falling with it, it is by no means so inevitably. In most actual cases nations are in fact sacrificed in order for the state to persist. ${ }^{89}$ This was the case in Germany, Italy and France, not to mention the other Imperial powers that took a direct interest in assimilating the cultural character of the nations they colonised to that of the coloniser. Understanding this is central to understanding the nature of borders and also the role of the state in creating nations - the most obvious case for Proudhon being France.

France, he argued, was made up of “d'au moins vingt nations distinctes, et don’t le caractère, observe dans le people et chez les paysans, est encore fortement tranché.”90 This tradition of local particularity and sub-national consciousness in the regions was stamped out by the French state over the course of the consolidation of its power but the cultural and ethnographic lineages and traditions nevertheless persist to this day. "Otez cet appui à la police centrale, la France tombe en fédéralisme. Les attractions locales l'emportent." "91 Indeed, Proudhon argues that had the Girondins won out against the Jacobins, this might well have happened. This argument escaped Carr's attention, who once claimed that "the suggestion of distributing French sovereignty in the name of federalism does not occur to him" ${ }^{\text {92 }}$ and that this could be taken as a sign of Proudhon’s chauvinism. This, as we should now be able to see, is simply incorrect.

\footnotetext{
${ }^{88}$ Ibid., p. 14.

${ }^{89}$ Ibid., p. 15.

${ }^{90}$ Ibid., p. 105.

91 Ibid., p. 107.

${ }^{92}$ Carr [1948], p.51. On the matter of French Algeria, Proudhon is relatively quiet. He did argue that Algeria is a lost cause and the French should never have gone in. The people will never be entirely assimilated because of the distance between the two cultures, it is too expensive a trophy to sustain and the people do not want the French there. It is purely a military occupation and "les conquérants d'exécrables charlatans tôt ou tard châtiés par la force dont ils abusent.” Proudhon [1998], p. 212.
} 
Proudhon continues that to the north of what was then conventionally called France, the Francs were, relatively speaking, no less diverse, but they were certainly not French which abrogated French claims there. According to the international history of their political alliances, overseas exploits and culture, they were distinctly anti-French. Proudhon argues further that religion had divided the region of the Rhine from France since they were largely Protestant to the north. And finally, Proudhon makes the good point that holding the Rhine would be futile unless the French could also secure the Channel - the lynchpin of British power - which provided the security of an independent Rhine and remained the one insurmountable block to French imperial ambition. ${ }^{93}$

Proudhon argued that the lower-right side of the Rhine had been effectively German since the end of the tenth century, and is today represented by the state of Luxembourg. The strategic purpose of Belgium and the Low-Countries for Europe lay in their location as a buffer zone between France, Germany and Britain. To Proudhon they protect the historical development of Europe by neutralising the domination of any one power and by protecting the division of peoples across this axis. Belgian neutrality, Proudhon argued was therefore given by geography, history and the security of Europe. Moreover, “[q]ui la viole, est coupable devant le genre humain."94 The persistence of the nation and the state is thus intimately tied to the European balance of power and for Proudhon had little to do with any underlying natural tradition of cultural or civic particularity. Proudhon argued that:

C’est en vain qu’on invoquerait, à la manière de Rousseau, le droit de nature, la souveraineté inaliénable, et autres grands principes oratoires. Si le développement historique de la civilisation exige que telle nationalité soit absorbée dans une autre, elle le sera, et il sera juste qu'elle le soit, jusqu'à ce que son heure vienne de reparaître. ${ }^{95}$

\footnotetext{
${ }^{93}$ Proudhon [1868], p. 114.

${ }^{94}$ Ibid.

${ }^{95}$ Ibid., p. 140.
} 
Proudhon did not foresee the emergence of Prussian dominance in Germany, Germany's invasion of Belgium which sparked the First World War and her invasion of Poland sparking the Second. Nor should we expect him to have. During Proudhon's lifetime the Italian and Polish questions dominated the political discourse of the day. German rearmament and internal restructuring along broadly Napoleonic lines were overlooked by most - not only Proudhon as I will discuss in the following chapter. At the time Proudhon believed that Germany would move quickly and peacefully towards a natural federation of its distinct regions and be a symbol of light to Europe. ${ }^{96}$ He also believed Germany was heading for a peaceful federation of peoples where all would be able to enjoy the fruits of unity without any of the "risques de la centralisation; [...et] à jouir de toutes les libertés politiques promises lors de la grand coalition contre Napoléon, en 1813. ${ }^{\text {,97 }}$ He was also convinced of France’s military superiority arguing, as would most of his contemporaries, that the French army "est la plus formidable machine de destruction qui existe, supérieur même à ce qu’elle fut sous le premier empire.”98 But this simply wasn't the case. Within four years of his death the military balance of power had shifted from France to Prussia and from sea power to artillery. Moreover, as Otto Pflanze has argued, Bismarck's

theft of the national cause from the hands of the German liberals [...] demonstrated that nationalism could actually be assimilated by the conservative political order. It was his genius to realize that in the mass age autocratic monarchies required new legitimation [...] Through German nationalism he provided the Hohenzollern monarchy and the traditional social order in Prussia with a new and more powerful moral foundation. While democratic liberalism [nascent in France at this time] remained inimical to autocratic government, nationalism became in Germany its principal justification. $^{99}$

\footnotetext{
${ }^{96}$ Proudhon [1867], pp. 63, 66.

${ }^{97}$ Proudhon [1998], p. 180.

${ }^{98}$ Ibid., p. 101.

${ }^{99}$ Pflanze [1966], p. 131.
} 
But this way of thinking was also used by revolutionaries across the world to support anti-statist as Anderson has shown. The flexibility and malleability of the discourse of nationalism was a central feature of the post-revolution legitimation of political power, and masked a changing of the guard rather than popular enfranchisement. Despite his many blind spots, Proudhon astutely observed this process and his work is thus arguably unjustifiably ignored.

\section{Conclusion: Switzerland and the Federal Principle}

Louis Napoleon's efforts to redraw the map of Europe in his favour were an utter failure and the forces of nationalism and statism he championed and manipulated, including those of Poland and Italy shattered the nineteenth-century world order. He lost control of Italy, and then after 1866 and Bismarck's support of the Hungarian, Czech and Italian causes, of his popularity in Germany. Louis Napoleon was no longer the doyen of nationalism - he was soon to be its victim. When the Prussians broke through meager French defences in 1870, and Paris was taken over by the communards in defence of France (seen to be Paris for all intents and purposes as I will show in the following chapter), Napoleon ordered his Prime Minister Adolph Thiers, an adversary of Proudhon's in the revolutionary 1948 government, to turn the troops on their compatriots. Nearly 20,000 communards died in the ensuing repression of a civil war in a city.

It is not too difficult to argue the empirical weight of Proudhon's foresight. His views are also being widely repeated. For example, the military historian Michael Howard has argued that,

hypnotised by the apparent transformation of warmongering capitalists into a strong force for peace, liberals and socialists in 1914 underestimated the true dangers: those arising from forces inherent in the states-system of the balance of power which they had for so long denounced, and those new forces of militant nationalism which they themselves had done so much to encourage. 
It was these which combined to destroy the transnational community they had laboured to create. ${ }^{100}$

Proudhon thus stands squarely outside this tradition of militant and paradoxical nationalist internationalism. Moreover, the demand for the entrenchment of states within global systems of constitutionalism is a little known aspect of his thinking but one which I will show was central to his entire political philosophy. What this chapter has shown is that for Proudhon the balance of power is a vital determinant of the "metamorphosis" of society. ${ }^{101}$

Breuilly's account, indeed most historical and theoretical accounts of the rise of the nation state, present this process as without real alternative and inevitable. Proudhon, however, does not and his extensively articulated alternative, and its suppression by force through active campaigning against his ideas, illustrates the rational and conscious, not to mention by his analysis utterly misguided, path taken by state leaders and revolutionaries in the run up to the twentieth century's two World Wars. This is not to argue that Proudhon was the only beacon of hope in turbulent times. On the contrary. Proudhon also repeatedly points to the Swiss and their confederalist system as his inspiration for an alternative political direction for Europe. That Switzerland is routinely considered the anomaly in nationalism studies is a case in point.

As Oliver Zimmer has pointed out, when Mazzini "presented his map of a Europe of Nations, Switzerland did not figure on it. In Mazzini’s vision, the small republican state in the heart of Europe did not constitute a nation [...] the Swiss nation-state, from Mazzini's perspective was both too small and too culturally diverse.”102 Rather than see this diversity as a flaw, Proudhon saw in it a symbol of its strength. He too argued that the Swiss confederation was not really a state, and this was precisely why it worked. He isolates five main factors in support of this. First, its constitution respected the autonomous and nominally sovereign rights of each of its numerous cantons. Secondly,

\footnotetext{
${ }^{100}$ Howard [1978], p. 72.

${ }^{101}$ Proudhon [1867], p. 312.

102 Zimmer [2003], p. xiii.
} 
the constitution was flexible enough to be rewritten and amended each time the internal balance of power necessitated it. Third, the federal and cantonal budgets were (and remain) separate. Fourth, the central federal polity does nothing but serve the interests of the individual cantons - it does not define them - and all delegates are recallable and directly responsible to the cantons rather than any other political cleavage. Fifth, there is no standing federal army, nor a centralised police force, and Proudhon believed, rather perceptively perhaps, that this model ought to have been applied to resolve the American Civil War. This system might have counterbalanced the centralist tendencies of the north. ${ }^{103}$ Proudhon even cites article 12 of the Swiss constitution (1848) that makes it illegal for Swiss journalists to accept prizes from foreign politicians as a sign of its enlightened awareness of the partisan priorities of the press. ${ }^{104}$

What commentators, including Proudhon, note is that the history of the construction of the Swiss national identity is inextricably tied to the defense of plurality and a pride in the particularity of the Swiss national identity. But this national identity is constituted not by the imposition of uniformity, but in the respect for diversity. The country has consistently resisted the Europe-wide norm of cultural and political homogeneity, preserving a "combination of shared rule and self-rule [which] enabled the country to create diversity in unity”, 105 and that has been constitutionally protected since 1848 . It is also worth noting that "[d]espite its traditional name [...], the modern Swiss political structure does not fit the modern concept of a confederation, but is rather a federation." ${ }^{106}$ The sovereignty of the federal structure is limited and shared, the complexity of the current institutional format persisting in its desire to assure cantonal and communal autonomy and self-governance. There is weighted voting in the federal parliament with the smallest cantons balanced with the larger ones with the principle of primus inter pares seemingly governing even the President's role. There is a tradition of direct democracy in all the communes and cantons and a strict observance of the principle of subsidiarity through all

\footnotetext{
103 Proudhon [1867], p. 51.

${ }^{104}$ Proudhon [1867], p. 183.

105 Stauffer et al [2002], p. 316.

106 Ibid., p. 317.
} 
levels of government. Even the federal court is subservient to the cantons. Stauffer et al continue that,

The usual explanation of this unique constitutional provision is both historical mistrust of judges, and an extremely strong belief in democracy. This led the constitution-makers to the decision that judges should not be able to abolish what has been decided democratically. In practice, the trust the constitutionmakers had in the democratic institutions has mostly been justified. ${ }^{107}$

The complexity and depth of the balance of powers within the Swiss federation is precisely what Proudhon thought ought to be replicated within all states and between them. The checks and balances were exactly what he advocated. But not only did he advocate these checks and balances in relation to the internal make up of states, he also advocated this balance of power between them. Developing republican constitutionalism, as a necessary first step, was not only good in terms of domestic order and justice, it was also vital to securing international order by making it harder for states to act without the consent of the people. What Proudhon sought was to use federalism and mutualism, both explored in more detail in chapter six, to restrain states by democratizing society. Internationally, Proudhon championed and defended those treaties he thought would restrain states in terms of their mutual relations with one another. The principle and objective at both levels is the same. The question is: on what basis did he justify this normative theory and where does federalism end?

It stands to reason that Proudhon's ideas did not come to him ready formed. They were fashioned out of the same materials available to everyone else. In the following chapter we will begin to understand these materials and examine the social and intellectual trends Proudhon had to contend with - most notably the material rise and intellectual justifications for statism. This will illustrate the social context with which Proudhon engaged and will also provide part of the explanation for why his thinking was so contentious at the time. I will develop this in chapter three where I show the

${ }^{107}$ Ibid., p. 320. 
philosophical consensus of the period as reflected in the ideas of Rousseau, Kant and Comte. Chapter four will begin Proudhon's philosophical critique of their positions and begin to reconstruct a far deeper basis for his normative defence of federalism than the purely pragmatic one presented here. 


\title{
Chapter 2
}

\section{The Change and Entrenchment of Étatisme in Nineteenth-Century France}

\begin{abstract}
Et parce que depuis dix ans j'ai pris un autre ton, parce que j'ai laissé la polémique pour m’enforcer dans les idées, vous me dites, après les calomniateurs et leur séquelle, que je deviens un modéré, un conservateur, un partisan de la doctrine (on sait ce que cela veut dire), un suppôt de la SainteAlliance, enfin! Je suis suspect, enfin; mais les gens du Siècle, de la Presse, de l'Opinion nationale, tous ces soi-disant démocrates admirateurs des merveilles impériales, ils sont populaires; ce sont de vrais patriotes, de vrais représentants de la liberté?
\end{abstract}

Proudhon. Letter to M. X

12 October, 1861.

\section{Introduction}

The previous chapter outlined the political and social surge towards nationalism in nineteenth-century European affairs. I argued, through Proudhon and by reference to the secondary literature on the period, that nationalism was an ideology of political order that was used to rally people to often quite contradictory ends, but with the near universal result of consolidating and re-legitimising the modern state. This chapter has two main purposes. First, to provide a parallel analysis of the change and entrenchment of étatisme in France during broadly the same period, ${ }^{1}$ and secondly, to provide a snapshot of the intellectual and social context out of which Proudhon’s thought emerged.

\footnotetext{
${ }^{1}$ The Larousse Compact defines 'étatisme’ as “Doctrine préconisant l’intervention de l’État dans les domains économique et social; système qui applique cette doctrine”. The Collins/Robert French-English dictionary translates étatisme as "state socialism, state ou, government control" but does not translate it as statism. The Concise OED describes statism as "centralised State administration and control of social and economic affairs" but without asserting that it was a particularly Socialist doctrine which is far closer to the historical evidence. I understand statism in this way.
} 
In its later phases French étatisme undoubtedly contained strong state socialist as well as bourgeois elements which undoubtedly coloured the specifics of its content, but as Sudhir Hazareesingh has shown, it "evolved without a durable experience of a 'strong' executive and in spite of the absence of a consistently and comprehensively Napoleonic [i.e., legalistic and authoritarian] structure." ${ }^{2}$ What this implies is that the institutional structure of the French state was under construction and consolidation at this time and the eventual nature of the state was not obvious. My approach to the subject largely supports this analysis.

My narrative differs from Hazareesingh by focusing less on the institutional development of the state than on the ideologies which buttressed the changes and the socio-economic origins of these ideologies. The narrative has two intertwining threads. First, I argue that the conceptions of what étatisme ought to mean and how it ought to be enacted changed over time, but became entrenched in the modern Republican form by the 1870s. Étatisme was thus less an objective structural fact than an ideological movement in search of the fact; it was something that was actively campaigned for and created out of the materials of the past; an ideal of how society ought to be organised that was in a constant process of being realised and undermined by plural and contradictory social forces including ‘international’ ones.

Secondly, however, I will show that the ideological debates happened within particular and objective social contexts that themselves changed and entrenched a particular notion of étatisme. Agents were not free from the structures within which they articulated their analysis and programmatic ends. I will show that by 1870 statism, to use the English translation, had merged into a complex set of ideas and traditions, spliced into a industrialising and militarising France, about why the state ought to govern society, and the divide between socialists and liberals as to the content of this governance. The evolution of the actual structure and power of the state itself changed and entrenched oppositional and non-oppositional ideologies.

\footnotetext{
${ }^{2}$ Hazareesingh [1994], p. 175 (emphasis added).
} 
The narrative begins before socialism and before the existence of the modern nation state. It begins with the French Revolution in 1789 and ends with the French Prime Minster Adolph Thiers' crushing of the Paris Commune using the might of the French army. Neither was necessary nor inevitable, nor was the resulting state of affairs what anyone had actually actively campaigned for - least of all Napoleon III who failed so spectacularly to stop the Prussians from entering Paris. My analysis is therefore nonreductive but foregrounds the ways in which intellectual traditions responded to and shaped material structural processes. Specifically, the approach leans on the work of Roberto Mangaberia Unger, and,

acknowledges the central importance of the distinction between the formative institutional arrangements and imaginative preconceptions of a society and the routine practical or mental activities that these structures help shape. It recognises that such institutional and imaginative frameworks cannot be adequately explained as the cumulative results of a society's normal episodes of conflict and compromise. It shows that we do not need to predefine possible trajectories of large-scale, discontinuous structural change in order to understand what happens in history. It [the sociological method employed] severs the link between our ability to explain past or present situations and the premise that these situations were or are necessary. It enlarges our sense of the real and the possible. It places explanatory ambition on the side of an acceptance of contingency and an openness to novelty. ${ }^{3}$

What does this mean in practical terms? What I want to discuss is how macro normative processes or the idealisation a possible society, championed by individuals and the political communities they formed, were articulated within particular institutional and social-structural constraints. The broad tendency was, however, towards statism as an ideal of social organisation and this was the cumulative result of the period. The aim is to put people, and what they thought, at the forefront of analysis, but to understand ideas against the structural backdrop of the ideas of others and the material structures of nineteenth-century French society. I discuss the ideas of Louis Blanc, Saint-Simon, the

\footnotetext{
${ }^{3}$ Unger [1987c], p. 1.
} 
Saint-Simonian feminists and Fourier and his followers, and I look at the ways in which Rousseau's work was used by social theorists and political actors. All of this is set against the backdrop of the changing relationship between social forces and the French state, the industrialisation and militarisation of the state, and the relationship of capital and Church to the state.

Constructing the narrative in this way has an important normative implication. The analysis contributes to the "pursuit of the goal of plasticity [that] requires the invention of institutions that turn economies and polities into machines for the ongoing destruction of all privileged claims on the resources - of capital, power, and expertise - with which we make and re-make society." ${ }^{4}$ Central to this position is the argument that things might have turned out other than they were. Nevertheless, the key tendency evidenced at this time is the change and entrenchment of étatisme and the narrative seeks to account for this because it is against this context that we need to understand the development of Proudhon's anti-statism.

The chapter is structured according to six key themes in French history and each theme is structured around five key dates. The six themes provide the following sections: (1) the evolution of Science, Industrialisation and Militarisation; (2) the change in Capitalism, Socialism and the Emancipation of the Third Estate; (3) the Evolution of Feminism; (4) the rise and fall of New Religions and the Church; (5) the change in positions on Pacifism and Bellicosity; and finally, (6) the rise and fall of Nationalism, Internationalism and Regionalism. ${ }^{5}$ The key historical nodal points are the French Revolution of 1789, the Congress of Vienna of 1815, the 1848 Revolution, Louis Napoleon's coup of 1851, and the Paris Commune of 1870.

At each of the key nodal dates, these plural and contradictory social forces converged upon, or criticised, the state as the legitimate locus of activity. They also often changed their approaches after facing different conflicting forces, forces that not so long previously were key allies. At these points of change, social organisation or control was

\footnotetext{
${ }^{4}$ Ibid., p. 2.

${ }^{5}$ Space does not permit a discussion of French anti-Semitism, which, while not endemic, institutionalised and at the forefront of public debate until after the time-scale under discussion, was nevertheless important.
} 
consolidated, justified and enforced through the entrenchment of étatisme. What I will show is that debates surrounding the proper role of the state in society created a 'domestic-centric' bias in social theory that ultimately boiled down to the general opinion that what was good for France was good for Europe. This process culminates with Napoleon III's European imperialism under the pretext of championing the nationalist cause overseas, his defeat at the hands of the Prussians and the first major shift in the European balance of power in over a generation. By incorporating many of the institutional and imaginative practices of French étatisme, the Prussians outstripped the French militarily and industrially. It is against this background that the political purpose and the broad social origins of Proudhon's anarchism should be understood, and each section concludes with a brief discussion of its significance for Proudhon's later thinking about world politics, discussions that are substantially expanded in chapters four, five and six.

\section{Science, Industry and the Military}

A focus on the role of science in the industrialisation of the military is a vital element in explaining the change and entrenchment of étatism because, as I will argue here, the militarisation of the state is perhaps the key explanatory factor in explaining the rise to hegemony of a centralised and dirigiste state in France. ${ }^{6}$ Indeed, as McNeill and Skocpol have shown, foreign wars, military success and failure contributed directly to the Revolution by draining fiscal resources and exacerbating the contradictions and problems of French society. ${ }^{7}$ With the onset of the Revolutionary Wars the levée en masse also performed an important role in alleviating pressures on French society by taking men abroad and, as Proudhon so eloquently put it, making foreign lands pasture for French citizen-soldiers. The early Revolutionary period, particularly the Jacobin Terror, had engendered social insecurities which led many to see the army as a means of escape, and form of routine, unachievable in the society it was designed to protect and enrich.

\footnotetext{
${ }^{6}$ This is not a standard history of French political and social change but one which leans on Proudhon's theories outlined further in chapter five and the work of Mc Neill [1983] amongst others. For other economic and social histories of France see for example, Price [1987], Jenkins [1990], Charle [1994]. ${ }^{7}$ McNeill [1983], p. 184; cf. Skocpol [1979].
} 
McNeill writes that "Paradoxical as it may sound, escape from freedom was often a real liberation". ${ }^{8}$ And yet, again paradoxically, by abandoning the graft of rural or urban toil for the adventure and security of the army, the war exacerbated economic crises within the very countries whose glory animated the pride and bellicosity of the military.

As Hippler has shown, the army was also an important training ground for French civic values, where soldiers were inculcated with the French Revolutionary élan and rendered citizens by virtue of their willingness to fight for la patrie and for the Revolution. ${ }^{9}$ From this period, as will be discussed further below, for the first time in French history, a national military became associated with France as a single unified entity, as well as being indelibly linked to the Revolutionary ideologies of the time. In very important ways, France, the Revolution and the military became one and the same thing.

But the average soldier's faith in the Revolution was accompanied by an equally profound faith in a particular notion of science that animated the strategists that sent them out to fight. For example, the work of the Baron General of Brigade, Antoine-Henri Jomini fused élan and scientific strategy. This fusion took place in both the strategy and in the re-writing of revolutionary history. He argued, taking Newtonian approaches to science as his guiding paradigm, that overwhelming force animated by this revolutionary zeal to be sure, but applied to a geometrically ascertainable point of attack and pressure was the core to military success. Through this process of 'scientific innovation' he unhooked military strategy from its social context and from actual historical practice. ${ }^{10}$

This was by no means an anomaly of emerging scientific theory, but had many antecedents. By the time Comte's positivism came to be defined as a science of social order, it sought less to ignore morality and society than to structure it according to its own internal laws. But this approach had clear antecedents. For example, Turgot, Baron de l'Aulne, was a key architect of successive failures on the part of the French monarchy to reorganise society according to rational scientific principles prior to the Revolution. ${ }^{11}$

\footnotetext{
${ }^{8}$ Ibid., p. 254.

${ }^{9}$ Hippler [2007].

${ }^{10}$ Shy [1986], p. 163.

${ }^{11}$ Price [1993], p. 85.
} 
His faith in reason prompted him to subjugate all knowledge to the exactitude of mathematical precepts which he believed could become the root of progressive, secular politics since they were unconnected to the vicissitudes of life and superstition. Access to this truth was open to the adept 'Men of Genius' who ought to be nourished and allowed to govern the social order, because through grasping the mathematical certainties of life they were the key to 'progress'. "To know the truth in order to make the social order conform to it, that is the sole source of public happiness. It is therefore useful, even necessary, to extend the limits of knowledge [...]"12 In my view no bolder statement of the hubris of the nobility in relation to social engineering can be found. Despite its philanthropic subtext the impression is clear: society ought to be the object of elite control. Which section of, or where this elite ought to come from, was of course violently contested, but from the outset they were deeply committed to the state and nearly all its agents

By 1815 and the end of the Revolutionary Wars, the French nobility were not destroyed as a social class, but they were now power-sharing under the restored autocratic monarchy of Louis XVIII with a new wealthy and industrious bourgeoisie. The later believed passionately in the need to reconstruct France in the aftermath of wars that had left her exhausted both physically and psychologically. In relation to the latter, seemingly immutable social orders had crumbled before Napoleon's armies and the place of God in the social order was severely undermined. For example, Napoleon's eviction of Pope Pius VII from his state(ly) home between 1808 and 1814 dealt a serious blow to the certainties of the old order. This weakening of the previously immutable moral and social order by force is a vital aspect of the context of the period. It is only if we see the period in this context that we can understand why religion and moral certitude was also so central to the industrial ideologies of the key protagonists who sought to reconstruct society later.

The Count Henri De Saint-Simon is typical but his ideas were more epochal than most. He was born of noble stock and claimed to be able trace his ancestry back to Charlemagne, whom he claimed visited him in dreams. ${ }^{13}$ Although he took no part in the

\footnotetext{
${ }^{12}$ Manuel [1965], p. 42.

${ }^{13}$ Manuel [1965], p. 109.
} 
revolution, he nevertheless profited directly from it and emerged even wealthier. He eventually lost his fortune and was disowned by his family for his radical views, but he nonetheless surfaced as the champion of the new industrial bourgeoisie, marvelling in the scientific acumen of this group and actively campaigned for the fulfilment of their historical destiny to become the new rulers of the world.

Saint-Simon railed against the Church and the ancient vested privilege of the nobility. He saw them to be retarding society, holding back the individual initiative of 'Men of Genius' all of whom were heirs to the legacy of the likes of Newton or Napoleon, and who like them ought to be moving society forward. He was, however, disparaging of revolutionaries and the individualism he believed accompanied critical thinking that was not organised for a higher social purpose. In a work co-authored with Auguste Comte, one we will discuss further in the following chapter, he famously proclaimed: "The philosophy of the last century was revolutionary; that of the nineteenth century must be organisational." ${ }^{„ 14}$ Central to the re-organisation of society was according the scientists the new upper cadre of society and then dividing the rest, famously, according to need and capacity - a motif that was to echo through the nineteenth century.

In the Saint-Simonian polity, the elite cadre of scientists ought to be organised meticulously but given complete freedom to work and to devise the plans for a future society. Beneath the scientists would be the industrialists who would enact the scientists' plans and invest the people with the public-spiritedness necessary to sustain the entire edifice. Despite the clear hierarchy, Saint-Simon believed all people fit into one of three capacities and it was accident of birth that differentiated them socially. Thus those with the scientific capacity may be of lowly birth but they ought to rise and rule, like Napoleon, by virtue of their acumen. This acumen might be a motor capacity and would thus mark out the individual as an industrialist. Those of a more sensory nature were the social glue. They would be moralists and artists, individuals who would infuse the sterile and hierarchical social order with a romantic secular religion. ${ }^{15}$

\footnotetext{
${ }^{14}$ Cited in Taylor, [1975], p. 34.

${ }^{15}$ Manuel [1965], p. 124-125.
} 
The extent of this plan for the spiritual regeneration of society will be discussed further below. However, Saint-Simon's organic conception of society lent heavily on the Catholic and Theocratic ideas of de Maistre and de Bonald, as they undoubtedly would in the Restoration period. These ideas had added force in galvanising the broken postRevolutionary society. The philosophy of history of the Catholic theocrats and SaintSimon were also remarkably close in terms of their explanation of the role of war in human history. All saw war as a process through which society evolved through the expression of spontaneous genius and, in the more extreme Catholic ideas of de Maistre, through the pruning of the human tree. The knights and clergy of the old order, massacred in war, were replaced by the new technocracy and the anarchic machinations of a factionalised France were overcome in the transcendent unity offered by the new scientific organisation of society. Thus war was the motor of change. While SaintSimon's ideas did not meet with immediate success, as Keith Taylor has argued, by 1870 not a single social theory in Europe was untouched by this doctrine. ${ }^{16}$

Saint-Simon died in 1825, a year after the medieval pomp of Charles X's coronation which symbolised "the new alliance of 'throne and altar'."17 This was also the period of the industrial revolution in Britain. Here, industrialisation was spurred by state military expenditure and the exploitation of the colonies. This was unmatched in a France still reeling internally from the aftershocks of the political upheavals of the period and embroiled in a wasteful colonial war in Algeria (1830). But this situation changed entirely from the 1840s. In the relative calm of the European order, transport and military innovation gathered apace with Saint-Simonian industrialists leading the way. Turning to both, I will now show how the scientists and engineers of France came of age and how from 1851 the state took control of both.

The post-revolutionary 1848-1851 period of the Second Republic saw thousands of workers massacred by the army and a nascent state police. However, once Napoleon III assumed power in the coup d'état of $2^{\text {nd }}$ December 1851, things began to settle and change - though clearly not in the worker's favour. As Magraw has shown, Louis

\footnotetext{
16 Taylor [1975], p. 54.

${ }^{17}$ Jenkins [1990], p. 45.
} 
Napoleon spearheaded huge industrial and technocratic reform, inspired by SaintSimonians like Michel Chevalier, and buoyed by huge "state funding to overcome 'Luddite' elements in parliament." ${ }^{\text {,18 }}$ The national workshops, the key proposition of the Luxembourg Commission that I will discuss below, failed to generate any income or wealth, but the general principle of turning to the state to finance huge industrial works was a success.

The development of the railroads was the most important state led process of industrialisation in France. This generated huge wealth but for state technocrats and developed industrial monopolies through cartels. Cheap credit fuelled capitalist industrialisation with the rail booms of the 50s and 60s marking "peaks of economic growth" ${ }^{19}$ with industrial and naval sectors being the key beneficiaries of the new transport network. Coal conglomerates were merged under Louis Napoleon's supervision and industrial leaders were given key government posts, while the vast majority of his ministers were taken directly from the old order. ${ }^{20}$

The development of railways significantly shrank France. Whereas his uncle had tried to ensure that the borders of each department were no further away than a day on horseback, Napoleon III ensured that Haussmann’s new state and army-friendly Paris was a hub for the whole of France. The use of railways to transport heavy artillery and troops made war far easier logistically and this was used to devastating effect in Italy, while in the Crimea new ships built by Napoleon to correct his uncle’s logistic and strategic flaws at sea, were used to supply distant lands with ease. However, it was General Moltke of the Prussian army who would perfect the art of logistical strategy and it was soon evident that it was the new methods and techniques of manoeuvring of artillery, not sea power that would shift the balance of power to Prussia. ${ }^{21}$

Whereas in Britain, private investment fuelled initiatives which were then turned to military innovation and sold back to the state, in France it was state-led from the start.

\footnotetext{
${ }^{18}$ Magraw [1983], p. 159.

${ }^{19}$ Ibid., p. 160.

${ }^{20}$ Ibid., p. 166.

${ }^{21}$ McNeill [1983], p. 253.
} 
McNeill shows that during the 1850s the French military led the world technologically in two very important respects. First of all, with the launch of the Napoleon in 1850 the French navy gained the edge over the British in terms of speed and horsepower; then in 1858 the first iron plated ship, La Glorie, became the first ship to be virtually impregnable to any existing gun. Secondly, in 1849, Captain Minié developed a new bullet that expanded on firing to fit a rifled barrel and fire with five times the range but at an equivalent loading speed to a musket. Mass production followed in the wake of the Crimean War because military failure, disease and calamity provoked “a remarkable bout of warlike inventiveness", 22 with Florence Nightingale leading the humanitarian way, but in all other senses militarism continued apace with Louis Napoleon's France leading the way in design, manufacture and intensity.

And so, by the 1860s a "global, industrialised armaments business"23 had emerged. Despite British industrial and engineering ingenuity, France had led this move and "appeared in 1860 to be the greatest power of the European continent, in their own eyes and in those of expert foreign observers." ${ }^{24}$ It thus came as a complete shock to the French, and indeed the European balance of power itself, when in 1870 the Prussian army marched into Paris. Having been quietly developing and industrialising over the previous thirty years, building its own strategic doctrines around the thought of Carl Von Clausewitz, who was himself one of the most astute students of Napoleon Bonaparte, they simply trounced the French. And with this German philosophies gained a certain level of kudos which was to continue for the following half-century at least. It was clear to all that the Napoleonic experience was being replicated.

This process of military industrialisation not only structured state activities, but, as McNeill has argued, structured economic activities too.

In retrospect one can see that the industrialisation of war, so casually launched in the 1840s, played a leading role in forwarding the transition to managed economies. But this denouement was hidden from the actors of the

\footnotetext{
${ }^{22}$ Ibid., p. 237.

${ }^{23}$ Ibid., p. 241.

${ }^{24}$ Ibid., p. 245.
} 
age itself by the fact that before the 1880s initiative for technical change nearly always rested with private investors. ${ }^{25}$

This may have been the case in Britain, but was not so in France. It is clear that the liberal and industrial bourgeoisie were heavily involved in openly campaigning for state involvement in the military and in industry and many, such as Saint-Simon, had actively encouraged this involvement with his disciples becoming an integral part of the state elite. Moreover, as Berghahn has argued, between 1861 and 1864 Proudhon became the first to articulate a theoretical understanding of state involvement in the economy for the purpose of pursuing military ends, and defined it as 'militarism' for the first time in history. ${ }^{26}$ Processes in France were clearly less opaque than McNeill assumes and Proudhon's output in this period supports this. Proudhon's development of the concept of militarism presents us with is a new vocabulary to understand the nature of French political culture and how it was changing. The nineteenth century was a period when the state became French through the development of a citizen army, and the military (and thus the people) became the instrument of state power. ${ }^{27}$ Clothed in the rhetoric of nationalism, this was a potent weapon indeed. As I will show, it was not until the end of the century that things began to change dramatically, and people slowly changed their minds about the ability of the state to deliver on its Revolutionary promise.

Proudhon's particular argument in this regard will be discussed in more detail in chapter five, but it ought to be made clear here that the ahistorical, beneficent or providential nature of the state was constructed against markedly antagonistic realities. Proudhon and others clearly saw that the state was changing, and its features were made public by key protagonists, most of whom professed some form of republican socialism, which itself evolved over the century.

\footnotetext{
${ }^{25}$ Ibid., p. 224.

${ }^{26}$ Berghahn [1981].

${ }^{27}$ cf. Tilly [1985].
} 


\section{Socialism and the Emancipation of the Third Estate}

The changes in the theories of the republican left in the nineteenth century are often glossed over and have only recently been re-visited by scholars eager to jettison the cruder Marxist historiography of the period. It is now fairer to argue that nineteenthcentury French socialism evolved out of the thought of Rousseau and culminated with variants of Proudhonism, before Marxism took over in the final decades. This was not a process which somehow 'culminated' with Marxism (as thought destined to from the outset) but one which could have been very different. As John Plamenatz has argued:

If ever a political society existed that looked like a copy of (though a very imperfect one) of the ideal state described by Rousseau, it was not the revolutionary France of the Jacobins but the Paris Commune of 1871 [...] But the Communards were not disciples of Rousseau; if they took their doctrines from anyone, it was from Proudhon. ${ }^{28}$

The following chapter will engage with Rousseau's thought in detail. Here its legacy will be shown within the statist left in France to provide something of a foil for Proudhon's political theory. Rousseau's thought gave rise to distinct variants of social theory and it is important to contrast the Jacobin variants with the communalist, utopian projects of Fourier and others. But we will see as the chapter progresses how interlinked many of the themes and processes of the century were. My aim here is again to show how state-envy on the left, much like the left's nationalism, was co-opted and then manipulated by Napoleon III from 1851.

The ambiguity of French socialism begins with the concept of the Third Estate - the social cleavage that was the object of revolutionary emancipation at the turn of the nineteenth century. Siyée was referring to the French bourgeoisie when he asked that they be "everything" while they were at that time "nothing". They of course needed the support of the people in order to harangue the Old Order and 'the Paris mob', as it was

\footnotetext{
${ }^{28}$ Plamenatz [1952], p. xi.
} 
affectionately known, increasingly came to demand change on its own terms. However, while the sheer plurality of the factions and interests within the Revolutionary movement is impossible to convey here, some generalisation is necessary in order to convey the impact these movements had on future generations.

Broadly speaking the Revolutionary initiative was first associated with the Girondin faction within French politics. These were moderates and monarchists with regionalist inclinations derived from their conservatism and their desire to see the Revolution as a constitutional movement towards power-sharing and clemency for the defeated King. One of the lesser known key figures within this faction was the Englishman Thomas Paine who, fresh from the unprecedented success of The Rights of Man and his rebuttal of Burke in defence of the French revolution, was forced into exile in France where he was elected to the position of Deputy of Pas du Calais. His experience in drafting the American constitution and a close friendship with the Marquis de Condorcet made them perfect candidates to draft The Declaration of the Rights of Man and successive constitutions for the new French republic. ${ }^{29}$

On the other side of the revolutionary divide were the Jacobins, more bourgeois than aristocratic nobility in make-up and led by Robespierre, and who sought a far more radical revolution; an egalitarian and republican France 'one and indivisible', based on a Rousseauean conception of popular sovereignty and derived from a fear of division and thus of Girondin federalism. The relative weakness of the Jacobin faction in the Assembly was bolstered by the claims of the likes of Marat to speak on behalf of the 'people', which in practice turned out to be populist pandering to the Paris mob. The execution of the King, while popular in Paris, met with less support with broad swathes of the population in the provinces. Uprisings against the Revolutionary levée in the Vendée and elsewhere cast the Girondins as traitors, and they were guillotined in the ensuing Terror that sought to homogenise French politics. Thomas Paine was lucky to

\footnotetext{
${ }^{29}$ See Keane [1996, pp. 345-452] for an excellent discussion of Paine’s part in the French Revolution and his near-miss with the guillotine. Payne's letters provide a unique perspective on the unfurling drama of the Revolution that is completely overlooked in most other literature and one which sets the moral underpinnings of the revolution at the forefront. Drawing out the similarities between Payne and Proudhon's thought would be an interesting study in its own right.
} 
have escaped with his life. Condorcet was less fortunate and was executed at Robespierre's orders.

Fresh from disappointment in the new United States of America, Paine was alive to the danger which the sacrifice of the egalitarian principles of the Revolution to the assumed necessity of expediency and populism was dangerous for the moral rectitude of the Revolution. He saw first hand how paranoia, fuelled by the claims and counter claims of Marat, Danton and Robespierre, drove the Revolution into chaos and ultimately, the Terror. However, the ensuing historiography of the Revolution has turned on the necessity of the Terror and the egalitarian credentials of the Jacobin tradition which, once affirmed by sketchy historical analysis, came to shape popular attitudes to it in the nineteenth century. ${ }^{30}$ As Hazareesingh has argued,

the Jacobin tradition [...came to] celebrate the virtues of centralised authority throughout the nineteenth and twentieth centuries, occupying a hegemonic position in French intellectual approaches to the question of the relationship between State and civil society. The intellectual domination generated a set of normative assumptions about the nature of the State which were widely shared by leading political and economic actors, and cut across ideological divisions between forces of 'order' and 'movement'. ${ }^{31}$

Chief amongst these skewed and partisan histories were those of an Italian nobleman who traced his lineage back to Michelangelo. Phillipe Buonarotti wrote of his role in what came to be known as the Conspiracy of the Equals. This became a galvanising history of the socialist credentials of the revolution that was largely at odds with what actually transpired. When Robespierre was guillotined at the outset of the Thermidorian 'Reaction', many believed the Revolution was coming to an end - Gracchus Babeuf, the later-executed leader of the conspiracy, and Buonarroti, its historian, among them. They believed that the radical egalitarianism of Robespierre was the key threat to the old order and it was this that necessitated his execution. This commitment to equality (legal and

\footnotetext{
${ }^{30}$ Darriulat [2001] p. 127.

${ }^{31}$ Hazareesingh [1994], p. 167.
} 
material) drove the conspiracy which was nevertheless criticised for being bound to too abstract a set of duties.

For example, they campaigned for a more radical redistribution of land and property by the state. The Conspiracy organised secret societies that were hugely influential in terms of popularising an insurrectionary left (particularly in Italy) despite their limited success. The aim of the conspiracy and the secret societies was to push forward a vanguard-led revolution that would lead to a semi-permanent dictatorship of representatives of the people, necessary for the revolution to achieve the aim of the removal of landed property - the source of the enduring power of the nobility, and thus the poverty of the people. The Conspiracy of Equals was also an attempt to overturn an undemocratic Directory and to extend the ideals of the Revolution according to the principles set out in a particular reading of the history of Jacobinism - this tendency towards teleology on the left was given scientific weight later, as I will show in the following chapter.

In 1828 Buonarroti's publication Conspiration, which recounted the aims and principles of the conspiracy, planted the earliest example of state-led socialism in the public mind. Its historical accuracy is widely seen as questionable, but its impact is not. As Pamela Pilbeam has argued,

Buonarotti shaped attitudes to Robespierre, the Jacobins and Babeuf and in so doing gave a distinct "Jacobin" slant to early socialism. Jacobin and Robespierrist were virtually interchangeable terms to describe a radical at that time. It was Buonarroti who defined their neo-Robespierrism, presenting an image of the Jacobins that was far more democratic and more preoccupied with radical social change than the actual Jacobins had been. ${ }^{32}$

Whatever its actual nature, what was reinforced by the revolutionaries was that the seizure of state power was the principal means by which the principles of equality could be realised in practice. But this history-writing gave shape to a twin and contradictory cleavage within the French left that was of profound importance for its future evolution.

\footnotetext{
${ }^{32}$ Pilbeam [2000], p. 31.
} 
On the one hand, traditional Jacobins were centralist and statist and near-universally from the bourgeoisie. On the other, the radically egalitarian and insurrectionary socialism championed by the Equals (while ultimately statist in its ambitions) was also hugely influential amongst the sans coulottes of the post-Revolutionary period. ${ }^{33}$ The statist Jacobins were generally the rich bourgeois, "faithful to Rousseau"34 and anti-socialist. The radicals, no less enamoured of Robespierre but more involved in direct actions and secret societies, were also faithful to a particular reading of Rousseau but one which had social equality at its heart.

These cleavages were to become pronounced during the Restoration period (1815-1848) when socialism - the term coined by Pierre Leroux in 1830 - surfaced. The actual nature of socialism, republicanism and democracy remain hotly contested. For example, SaintSimon, although a liberal in every sense, was passionately concerned with the plight of the people and actively campaigned, as mentioned above, for a technocratic state that could directly alleviate the plight of the poor through industrial innovation and the application of scientific discoveries by a new industrial bourgeoisie.

The anti-capitalism of Charles Fourier, however, marks a distinctive shift in the relationship of socialism to the state. His anti-capitalism was born of his disillusionment with the free market and also with the type of 'civilization' the Revolution had ushered in. Originally a travelling salesman for the family firm, from an early age he became utterly disdainful of reductive first-principle rationalism, revolution and capitalism. Capitalism was based, he believed, on "lying and trickery" ; 35 mercantilism was based on the exploitation of the weak by the strong. Rationalism and the desire to come to notions of right and wrong through dispassionate analysis of the laws of nature and of thought, was no less destructive than capitalism since it repressed our natural passionate emotions. While he assumed a scientific posture, Fourier's was a classic re-statement of the revolt against reason which echoed Voltaire and Rousseau in substance if not in style or historical impact. Fourier developed the Romantic tradition in French thought, but used science to argue that our true passionate natures were nevertheless themselves as

\footnotetext{
${ }^{33}$ cf. Fehér [1987], pp. 128-148.

${ }^{34}$ Lobère [1961], p. 16.

${ }^{35}$ Ibid., p. 190.
} 
immutable, he believed, as the laws of the heavens. As such, moral philosophy and its reductive first-principle reasoning was, he argued, "the fifth wheel on the cart, impotence in action."36 What was necessary was to divine the essential and unchanging characteristics of our natures and build institutional structures within which they would flourish benignly. This stood in stark contrast to the prevailing approach which was to press for institutions that could be used to create better citizens. Beecher and Bienvenu summarise Fourier's project thus:

As he saw it the French Revolution was simply a spectacular proof of the vanity of the whole tradition of rationalist and "enlightened" philosophy. The philosophers had always attempted to impose rational norms on human behaviour, to repress and stifle the passions. The cause of the failure was quite simply that they had refused to accept man as he was. Institutions could be changed, but man could not. The passions were God-given and they were meant to be expressed. ${ }^{37}$

Fourier argued that humans ought to be grouped according to personality type and allowed to express their true natures within institutions designed to allow them to flourish. This was the idea behind the intricately designed Phalanstry within which humans would flourish and society would be pacified. As Talmon has argued, there was a deep faith in revolutionary France that “[m]en's hearts could be formed by laws”, ${ }^{38}$ but the content and author of those laws was hotly contested. Read as a critique of Turgot's pre-revolutionary confidence regarding the purpose of reason, and the Rousseauean idea that man could be perfected through good institutions, the revolutionary nature of Fourier's critique was clear, but was to have little influence anywhere until after his death and then in directions he could not have imagined.

But perhaps the clearest example of Jacobin socialist tradition is to be found in the ideas of the bourgeois, Madrid-born and Corsican-raised, Louis Blanc. Blanc was a disciple of Rousseau, and the influence was manifest in his early attempts to find "a new principle of

\footnotetext{
${ }^{36}$ Fourier [1996], p. 186.

${ }^{37}$ Beecher and Bienvenu [1971], p. 8.

${ }^{38}$ Talmon [1961], p. 133.
} 
authority which would serve to unify society". ${ }^{39}$ The result was a programme of doctrinal unity, led by a political and intellectual vanguard, and "moderation” in all policies and political demands. This moderation excluded him almost entirely from the radical left but endeared him to the establishment republicans. His Jacobin Socialism was an early attempt to unite "Jacobin democracy and cooperative socialism", or radicalism with statism, ${ }^{40}$ and by providing a reading of Rousseau for the socialist 1840s, Blanc's aim was to unite the promise of freedom in the former with the tools of authority inscribed in the latter.

Blanc had clear motives. For him the metaphysics of liberalism and capitalism was one of solipsistic sensualism tied to the liberal creed of self-interest and greed. ${ }^{41}$ Blanc, like Fourier before him, argued that the liberal free-market principle, and the competition it engendered, was fundamentally chaotic and destructive of society; the "state and freedom [...] are not contradictory, but correlative terms" ${ }^{\text {42 }}$ he argued, and 1848 he was given the opportunity to show this.

In the revolutionary ferment of 1848 Blanc was elected to the Assembly and given unparalleled responsibilities to remedy the plight of the working poor using the instruments of the state. His valiant attempt at state socialism was the famous failure of the Luxembourg Commission. The Commission responded to calls by the impoverished population for the 'right to work', demands based on the belief that the rich were restricting the amount of labour in order to keep wages down. Unable to force the rich to provide work the Luxembourg Commission created national workshops to provide state sponsored work. These quickly came to be seen as hand outs to pacify the militant Paris mob; it was a fiscal drain, and the political right quickly moved to undermine it. In fact, the workshops exacerbated economic contradictions and within two years had failed completely.

\footnotetext{
${ }^{39}$ Lobère [1961], p. 22

${ }^{40}$ Ibid., p. 15.

${ }^{41}$ Ibid., pp. 23-25.

42 Ibid., p. 26.
} 
With the coup d'état in December 1851 the Napoleonic state chose instead to undertake direct involvement in bourgeois interests instead. Louis Blanc went into exile in London and over six thousand left wing militants were forced into exile or deported - mostly to Algeria. ${ }^{43}$ Uprisings against the coup were brutally repressed while rural prosperity kept large swathes of the population on Louis Napoleon's side. ${ }^{44}$ With the ensuing repression of the press, civil liberties and rights of association, the workers movement was all but decimated in terms of its organisational hierarchy, and the remaining French left's ideological commitment to the state took a serious blow with the pendulum swinging towards Proudhonism.

While in exile, Blanc came to advocate a Babouvist "democratic technocracy"45 that would have been chauvinist in its foreign policy, virulently Anglo-phobic, conservative and mistrustful of the vast majority of the French peasantry and in total control of the economy. This reaction to failure was typical of the left, as I will show in greater detail below, and is a sign of the intellectual crisis that gripped the left in the latter half of the century. This crisis was exacerbated by Louis Napoleon's commitment to the 'social question' outlined in his work titled The Extinction of Pauperism. During the drafting of this work Louis Napoleon had held discussions with Louis Blanc and Proudhon about the best means to alleviate poverty. This was designed to boost his popularity on the left, while he brought the right into government. The resulting "Social Caesarism”, as Magraw has termed it, "pretend[ed] simultaneously to be Monsieur Proudhon and Monsieur Thiers". ${ }^{46}$ The dirigiste form of social protectionism and laissez-faire economics, coupled with industrialisation and militarisation, drove Louis Napoleon's desire to overturn the 1815 settlement and all that he saw as unjust and reactionary in it.

In this climate, the development of the statist ideology on the left over the previous twenty years took a serious blow. It became more common to argue that an ideology alone was insufficient, and that what was needed were the institutions. But certainty waned in the idea that these new institutions could work in perpetuity - even with the

\footnotetext{
${ }^{43}$ Moissonnier [1995], p. 154.

${ }^{44}$ Magraw [1983], pp. 164-165.

${ }^{45}$ Ibid., p. 150.

${ }^{46}$ Magraw [1992], p. 203.
} 
right men at the helm. In response to these historical changes, the statist argument evolved into an approach which considered the state a 'stage' in social and historical evolution as opposed to the end of political action.

Magraw has also shown that it was also during the Second Empire that we see the concept of class, particularly an articulation of an industrial working class, finally came to reflect actual social and political cleavages in France. With the rise of industrialisation and the expansion of heavy industry and national railroad-building, a new class of labourer emerged alongside a new materialist ideology to explain it. Still, the tenacity of the artisan workshops and the extensive peasant population ensured a consistent set of contradictions within the constituency of the left. ${ }^{47}$

In summary it was not clear to anyone what the correct mode of social organisation ought to be and Proudhon's was simply one approach among many to defining and organising social relations. Its distinctiveness resided in being neither communalist nor statist and being both radical and regional. Given the polarisation of politics and the strength of the revolutionary myth, occupying the 'centre ground' made it a difficult ideology to swallow. When Proudhon articulated his own mutualism, a theory I will discuss in the final chapter, its revolutionary reformism was popular, but because of its overt antistatism was mistrusted and misunderstood. This was because no one could understand how equality, order or progress could be delivered without the state, and few tolerated these ideologies coming from perhaps the only articulate (and prolific) rural working class pamphleteer in France.

\section{New Religions and the Church}

One of the key features of science, socialism and the state was their deeply religious elements. The evolution of Deism and secularism in France is a fascinating story and one which is often overlooked. In terms of our understanding of the millenarianism and romanticism of the Revolution, the religious and providential justifications used by

${ }^{47}$ Magraw [1992], pp. 199-233. 
Rousseau, Kant (which I will discuss in the chapter to follow) and innumerable other social reformers, is vital. What I will show is that nationalism, the state and history itself became infused with religious metaphor, designed to confer legitimacy on a particular social order. This will be discussed in far more detail in the following chapter because it is central to a full understanding of the ideas of Rousseau, Kant and Comte, and Proudhon as well. The focus here is on broader millenarian movements.

With the overthrow of the Old Order, its divine right monarchies, and Napoleon's imprisonment of the Pope, temporal power seemed to have emerged victorious but spiritually vacuous. The Revolutionary declarations and constitutions, and Napoleon's duplicitous role as protector of the Catholic Church, utterly unmasked and demythologised spiritual power, but left an existential gulf with nothing, it seemed, to orient people's moral compass. It is in this context that the Imperial and Republican French state took on its own religious aura - to the horror of the Holy Alliance against it.

It is not surprising, therefore, that without exception, religious motifs and symbols were also adopted by all the social reformers of the revolutionary and post-revolutionary era. Saint-Simon published a work entitled Nouveau Christiantisme (1825), Cabet, the first self-proclaimed communist, wrote another entitled Le Vrai Christiantisme (1840) both of which were hugely popular works of social criticism and reconstruction tied explicitly to a theory of the moral sentiments. Similarly, as Jones writes, Fourier's The Theory of the Four Movements [1808] “is a reminder that 'socialism' began as an attempt to discover a successor, not to capitalism, but to the Christian Church”. 48

Each of these writers, and innumerable others, subscribed to the basic moral precepts of Christianity, not as dogma, but as the historical tableau and thus proof of man's moral evolution. Christianity had only, therefore, to be updated to respond to and meet modern requirements. The Clergy, Saint-Simon argued, were now "the Antichrists", they had allowed the institution to corrupt the message of the Messiah. Society's fractured and poverty stricken reality was also spectacular proof of the failure of the Old Order and its use of the Church to legitimate it. The social critics turned their guns on the Old Order

\footnotetext{
${ }^{48}$ Jones [1996], p. xxvi.
} 
while using the very same theological legitimating for their own theories. As Manuel has argued,

Saint-Simon thought he was the reincarnation of Socrates and of Charlemagne; the [i.e., his] disciples evoked the analogy with Jesus; Fourier, though not given to historical learning, demonstrated from scripture that his appearance had been foretold. August Comte, at the end of the line, preferred to relate himself to Saint Paul, the organiser of the Christian order whom he exalted above Christ. ${ }^{49}$

Comte, 'The High Priest of Humanity' as he came to call himself, and the leader of the Positivist Religion, believed that "he had only to interrogate himself about his own spontaneous desires to know what the future would be - a procedure which has been followed unconsciously by many dissenters from the positivist religion." ${ }^{50}$ However, the popularity of these writers and their texts during the Restoration, illustrates quite how out of touch the Monarchy had become and the extent of the psychic, moral and political crisis the Revolution had bequeathed France.

During the 1830s and 40s Saint-Simon's followers “a group of brilliant, disturbed young men" 51 led by led by Olinde Rodrigues, began to found hugely popular communes on the outskirts of French towns and cities to which people would flock for their weekend breaks. These communes sought the rehabilitation of the flesh and the passions in a manner taken directly from Fourier and his disciple Enfintin. Indeed, the similarities bred tensions between the rival camps that were marked by the latter's virulent anti-Semitism. Many of the practices of these cults will be familiar to contemporary readers. Seizures, fits, speaking in tongues were all part and parcel of the New Christianity. On the other hand, by contrast, they also sought liberation through sexual emancipation, and saw the nuclear family as the root of social misanthropy. As we will see in the following section, feminism, or perhaps more accurately, the search for the female Messiah arose out of and had profound impacts on the re-articulation of post-Revolutionary France. The new

\footnotetext{
${ }^{49}$ Manuel [1965], p. 7.

${ }^{50}$ Ibid., p. 288.

${ }^{51}$ Ibid., p. 151.
} 
Christians were also deeply scientific with the members of the sects also having huge and famous successes in industry, in credit institutions, the Panama Canal and the railway networks of Europe. ${ }^{52}$

Despite this, theirs was a bona-fide religion. It had ritual, symbolism, dogma, a profound sense of the spiritual and of God, and all tied to modern conceptions of postrevolutionary social roots of psychic mania. Their solution was closed communities and a devotion to their spiritual leader - Pere Enfintin and those who followed him. They sought a fuller rationalism, one tied to a spiritual awakening and a sexual emancipation, as well as an industrious and enterprising ethic. They developed highly intricate plans for their communes, in which each would be satisfied according to natural needs and each would provide according to their capacities - that Saint-Simon's famous motto would be repeated by revolutionaries for decades to come is no coincidence. Finance capital was to drive social initiative and education was designed to emancipate the spirit, the key to an emancipated mind.

Less esoteric, but no less religious in tenor was the religious socialism of Louis Blanc. Lobère, Blanc's biographer, has argued that, “[f]rom the philosophers he learned to reason, but from the Bible he learned to feel. From it he first derived his sense of fraternity and he would later transform the Christ of the evangelists into a sentimental socialist." 53 This combined in Blanc to echo the Saint-Simonian view of "intellectuals, artists and industrial leaders" as a "sacerdotal corps", and teaching and journalism as "sublime priesthoods", journalists "the bearer[s] of a new dispensation."54 This would be insignificant were it not for the active parliamentary and publishing role Blanc occupied. Indeed, whereas the Saint-Simonians and Fourierists had been radicals and communitarians, Blanc was the quintessential deist étatiste.

For Pierre Leroux, another of the Jacobin socialists, the matter was equally explicit. For him the relationship of the individual to his nation was a clear parallel to that of the relationship of man to God. He argued that a belief in the kernel of religion was crucial to

\footnotetext{
52 Ibid., p. 153.

${ }^{53}$ Lobère [1961], p. 4.

${ }^{54}$ Ibid., pp. 43-44.
} 
any nationalist sentiment and the latter could not be guaranteed without the former. ${ }^{55}$ His vision of a "Religion of Humanity" was a mystified nationalism, with civil and religious ceremony made one, but with the Church removed from having any celestial sanction to its rule. Since le peuple were the new god, only the state could provide legitimate sanction.

During the Restoration the symbiosis of state and religion was most visibly manifested in elaborate public religious ceremonies and their "almost hysterical collective affirmation[s] of faith" ${ }^{56}$ These ceremonies dipped in frequency post-1830 but were revived "on a large scale again during the Second Empire [...] when their lessons were reinforced by a large circulation religious press”. This populist literature would demonise "Protestants, Jews, atheists and lay school teachers, Jacobins and ungrateful children". ${ }^{57}$ Indeed, Louis Napoleon's coup was greeted as “Divine Providence” by the Archbishop of Cambrai, and, "in the short term [...] and throughout the 1850s the Church benefited considerably from its close association with the Second Empire." ${ }^{58}$ The people flocked back to mass, and saw Napoleon III as Catholicism's temporal guardian. But despite the invaluable role Catholic missionaries played in the consolidation of French power overseas, and thus in the consolidation of Church power at home, ${ }^{59}$ this new alignment of Church and state was thrown into disarray by Napoleon's invasion of Italy and his threat to an independent Papacy.

This re-alignment of Napoleon with the Church aggravated the Republican left in France into a new round of anti-clericalism. Then when Napoleon brought financiers and Jewish Saint-Simonians into office, a new and more virulent bout of reactionary anti-Semitism developed out of it. It is also at this time that the myth of a clerical and Jewish cabal of financiers takes hold of the left's conception of the state - fuelled, it must be admitted, by some empirical evidence, but later exploded out of all proportion. It is notable also that from the 1870s certain orders of the Church were coming to suspect that Jewish and freemason conspiracies were undermining their fragile existence and by so doing

\footnotetext{
${ }^{55}$ Le Bras-Chopard [1986], pp. 329-342.

${ }^{56}$ Price [1987], p. 270.

${ }^{57}$ Ibid., p. 270-271.

${ }^{58}$ Ibid., p. 281.

${ }^{59}$ Hazareesingh [1994], p. 158.
} 
contributed their lot to the subsequent rise of anti-Semitism. ${ }^{60}$ In the event, it was not until the first self-consciously anti-Semitic tract - Drumont's La France Juif (1886) went through hundreds of editions and sold hundreds of thousands of copies, that antiSemitism can be said to have gripped the political culture of France. Both socialism and the Church are heavily implicated in this. By the end of the century the struggle for a new Christianity was on the side of the Church and the political right who in the face of an increasingly secular morality of statism, materialism and industry, and the demands for secular and civic education, fought rearguard actions to defend the continued existence of the Church as such.

In sum, the rise and fall of the Church interweaves with the rise and fall of new mysticism and the material transformations in French society. When the state and Church reunited during the Second Empire a new materialist atheism took hold of the left, fuelled by a scientism divested of the religious aura of the early Saint-Simonians. I will show in the following chapter how Comte was the last atheist mystic and that after him science increasingly became divested of morality. However, modernisation was not premised on the abandonment of religion. Quite the opposite. The state, nation, socialism and history itself becomes infused with religious ideas. This fact is vital to bear in mind if we are to understand how French imperialism and socialism became articulated as providential. Also, we need to see the scale of this tendency elsewhere to be able to recognise the absence of this tendency towards providence in Proudhon's works.

\section{Feminism}

The reason for the turn to feminism here is twofold. The first is the need to be able to contextualise Proudhon's anti-feminism and the lack of a male reaction to it in the late nineteenth century. Secondly, I also want to show that French feminism evolved from being anti-statist and perhaps one of the most progressive movements in the early to midnineteenth century, to renouncing suffrage and political representation almost completely under the Second Empire. What we find is that the backlash against a particular reading

\footnotetext{
${ }^{60}$ Price [1987], p. 283.
} 
of early nineteenth-century French feminism undermined the confidence and political ambitions of the French feminists, and Proudhon played a key role in this. Finally, as Pedersen has shown, the historiography of French social theory routinely ignores the feminists, ${ }^{61}$ and I do not want to be guilty of repeating this mistake.

While the history of French feminism stretches back as far as the 1670s and the writings of Poullain. In modern times, as with much that is significant about nineteenth-century France, it can be traced to reactions to the writings of Rousseau. The immediate spur was the contradiction between his egalitarianism and his anti-feminism. This gave rise to a feminist movement that later mixed with the Saint-Simonans and Fourierists and generated the millenarian search for the Female Messiah. These movements also demanded sexual liberation (civic, material and sensual), presented critiques of the family and put the cause of social malaise at the door of bourgeois morality. These movements, often led by women for women, produced very real and tangible successes. Abstract philosophies were translated into direct action and self-help feminist movements. These movements then developed political ambitions and looked to the state for civic legal recognition and then demanded full suffrage. But during the Second Empire the state turned into the instrument of conservative and rural reaction, and quickly moved to crush these movements. Unfortunately, the republican left, particularly Proudhon, also contributed directly to the decimation of one of the most progressive social movements in France.

In Emile Rousseau had argued that the proper place for women was in the family. Sophie, the works' heroine, ought to be confined to the home and her public role should only relate to her beauty and natural tendencies to sobriety and chasteness. This private role would temper men's public anti-social impulses, while civic education would complete the transformation. For Rousseau it was right that women should have no natural political rights. However, in the Nouvelle Héloïse, one of the most popular short stories of the eighteenth century, Rousseau seemed to rile against traditional family structures by portraying the protagonist, who was in love with her tutor, as having to chose between her father's wish that she marry a nobleman of his choosing or disgrace the family and

\footnotetext{
${ }^{61}$ Pedersen [2001].
} 
elope with her lowly tutor. In the end she chooses to follow the social values of the old order. This choice, Rousseau argues, is naturally her own and naturally the one women will always make. Héloïse does not suffer since she comes into harmony with her true nature. The problem is in society.

During the run up to the revolution women campaigned assiduously on behalh of women's rights and an end to the Old Order. What we find is that the chronology of the various demands for universal suffrage during the French Revolutionary period is an interesting reflection of general attitudes at the time. A year into the revolution Olympe de Gouges proposed 'The Declaration of the Rights of Women' (1790) the first article of which read: "Woman is born free and lives equal to man in her rights. Social distinctions can be based only on the common utility.” The declaration was unequivocal the equality of the sexes was central to peace and security. It was not until the next year the Robespierre demanded full and unconditional universal suffrage, but by this point he had turned against women, following Rousseau to the letter again, and wrote them out of his draft constitution. Mary Wollstonecraft then began openly campaigning against this Rousseauean bias in French sexual politics in her 'A Vindication of the Rights of Women’ (1792), which campaigned for equality in education, suffrage and rights. As she rightly pointed out: "the whole system of representation is now, in this country, only a convenient handle for despotism”. ${ }^{62}$ Abbé Sieyès, Condorcet and Thomas Paine began drafting a replacement constitution between 1791-1792.

Initially, Condorcet rose to the challenge of arguing the case for the equality of the sexes. Indeed argument was made, defended and enacted that to deny the natural equality of the sexes was to deny the natural harmony of the celestial universe of which women and men shared an equal part. ${ }^{63}$ However, with the onset of the Terror, Robespierre, following Rousseau's anti-feminism as Gospel, turned his wrath against the radicalised women of the revolutionary period. With the rise of Robespierre, Danton and Marat, the pressure started to mount for a populist constitution. Condorcet's failure to draft one was a result of his "tendency to look at the Revolution as a mathematical puzzle to be solved by the

\footnotetext{
${ }^{62}$ For an excellent selection of these texts with commentary, see Ishay [2007], pp. 163-188.

${ }^{63}$ Fauré [1991], p. 97.
} 
formula of natural and civil rights."64 He equated women's active campaigning for the Jacobins in the immediate pre-revolutionary period with a sign of their general unsuitability for political representation. He thus turned away from mentioning women directly in his draft of the 'Declaration of the Rights of Man'. The whole saga was a tragedy that ultimately culminated in the Terror and Condorcet's suicide. Tom Paine was lucky to escape with his life, after a plot was hatched to have him tried and executed as a Girondin. It was unsurprising that the feminists would come to fear for their lives too, ${ }^{65}$ and women's limited rights were rescinded in 1805. Of the constitution-writers, only Abbé Sieyès, a close follower of Kant, gained lasting fame for his role. This was undoubtedly because he gave reason to the revolutionary imperialism of Kant's plan for perpetual peace - an important distraction from the terrors at home. ${ }^{66}$

Not ten years later, Fourier took up the feminist cause again. Claire Goldberg Moses argues that Fourier's influence on the women's liberation movement was "immeasurable", and Zeldin has even claimed that he "invented the word". ${ }^{67}$ Needless to say he stands out in nearly all analyses as the most significant feminist of the first half of the nineteenth-century. Turning Rousseau on his head "Fourier... believed that all individuals, male and female, were born equal and were basically similar in nature. Only "savagery" had denied women rights and opportunities equal to men’s." ${ }^{\text {" }}$ He was the first to argue that the social status of women was a precise indicator of "harmony" within society - an argument Auguste Comte would repeat almost verbatim later. Manuel has argued that "[s]ince [for Fourier], the passions were constant, human history was a study in varying degrees of repression”,69 and so, with women's repression being the most glaring and obvious, "the extension of the privileges of women is the general principle of all social progress." 70

\footnotetext{
${ }^{64}$ Keane [1995], p. 358.

${ }^{65}$ Fauré [1991], pp. 94-97.

${ }^{66}$ Tuck [2001], p. 224.

${ }^{67}$ Zeldin [1979], p. 345.

${ }^{68}$ Moses [1984], p. 90.

${ }^{69}$ Manuel [1965], p. 213.

${ }^{70}$ cited in Grogan [1992], p. 20 (emphasis in original).
} 
Moses argues that feminism developed out of the political tension inherent in liberal universalist notions of the equal rights of men, and the obvious sexual inequalities which it overlays. "By proclaiming the political significance of sex, the [Civil] code helped shape a feminist consciousness." ${ }^{71}$ Feminists agreed that the endemic inequality in society contradicted and inhibited the realisation of the de jure equality claimed by the Civil Code. Early feminists turned to Revolutionary principles and motifs for their normative and revolutionary arguments. As had the bourgeoisie, women simply asked for equality before the law and universal suffrage.

For Fourier and his followers, and increasingly the followers of Saint-Simon, the only way to achieve this emancipation in the Restoration period was in the separation from political society as such. The successful Phalanstries and Saint-Simonian communes were places where free love and psychic emancipation were treated as one and the same thing. To be free to have multiple partners was central to avoid the manias which resulted from the repression of sexual urges and the more malign Christian doctrines of abstinence. Furthermore, it was argued that only if women were emancipated from the strictures of family life could they freely accede to these principles. Indeed, it is widely argued that Fourier, a travelling salesman by trade, utterly failed to realise his utopia in his own sex life and like many of his plans they have deep, personal origins. ${ }^{72}$

The women that made up these movements were far more direct in their activities. Emancipation was, as always, tied to education, and the struggle to educate women was led by the largely bourgeois French feminist movement through journals such as the Voix des Femmes, Opinion des Femmes, through public campaigning, and community work with prostitutes, orphans and the poor. Tribune des Femmes was later run as a wholly independent journal for women and run by women. Feminism also had a distinctly socialist flavour in the work of Flora Tristan who, four years prior to the publication of the Communist Manifesto called to workers to emancipate themselves through unionisation. $^{73}$

\footnotetext{
${ }^{71}$ Moses [1984], p. 18.

72 Pilbeam [2000], pp. 75-78 Manuel has drawn our attention to the similarities between Fourier's formulation and that of Freud. See Manuel [1865], pp. 225-233.

${ }^{73}$ Ibid., p. 108.
} 
This movement had all the hallmarks, and many of the successes, of a vibrant and new social movement. The grass-roots campaigning and social work of these women (for example, assisting with illegitimacy, counselling and protection for the huge numbers of concubines and prostitutes) was as revolutionary as the labour struggles of the following years but gained nothing of the status of the latter. But by the late 1830s Fourierist and Saint-Simonian communes and retreats had become something of a social spectacle rather than a self-help movement. Politicians and the Church came to suspect their malign influence on the Old Order. Slowly, internal divisions and power struggles also made the male-dominated hierarchies of these movements increasingly untenable, and over time Enfintin's spiritual leadership of the group broke down. By the mid-1830s Enfintin had increasingly come to see himself as the 'Pope' leader of the movement in its search for the 'Female Messiah'. And, in the time-honoured tradition of quasi-religious sects, he came to see his sexual relations with his female cohort as part of this quest and his personal life as, rather conveniently, a religiously sanctioned one.

The death-blow to the feminist movement in the nineteenth century came when the SaintSimonians were put before a court on trumped up charges of attacking 'public morality'. Fourierist and Saint-Simonian feminism was widely and perhaps quite correctly seen as a deliberate and sustained attack on the nuclear family, a threat to a social order increasingly being re-defined according to traditional Christian values. This favourite charge of the state during this century won the day, and the Saint-Simonian movement never recovered. ${ }^{74}$ Later feminists downplayed this aspect of their beliefs not only because of fear of reprisal, but also because it became clear towards the middle of the century that the vast proportion of the French public saw the family as the most important institution in society and attacks on it as immoral. By 1848, just when one would expect them to become most radical, the feminist movement were careful not to be seen as advocating "immorality" implying sexual freedom and an attack on the family which was so prevalent in their early thinking. ${ }^{75}$

\footnotetext{
${ }^{74}$ Manuel [1965], pp. 189-192.

${ }^{75}$ Moses [1984], p. 133.
} 
In 1848 nearly 8,750,000 men were given the vote overnight. The state was no longer feared but championed, and women who had been largely underground in terms of their political activity came to the fore. In time honoured fashion, the revolutionaries decided after declaring universal male suffrage to postpone the people's exercise of the vote until a programme of education could be carried out to inform them of the purpose and benefits of the Republic. When national workshops and nationalisation failed the rural population rebelled. Widely seen by the male revolutionaries as reactionary and ignorant of their true interests they turned also against women who they believed to have been turning their men towards the Napoleonic counter-revolution due to their (again assumed) proximity to the Church. Despite the Republican government now being staffed with the Saint-Simonians who had spearheaded the search for the female Messiah up to that point, the pleas of the feminists fell on deaf ears. ${ }^{76}$

Ultimately even the feminists gave up their more radical demands. Faced with such a barrage of opposition even Jenny d'Héricourt, ${ }^{77}$ Proudhon's most famous opponent, refused to advocate suffrage for uneducated women after 1848. We will return to d'Hérricourt's critique in later chapters, but it is worth noting here that after the coup in 1851, she advocated education rather than suffrage, so that women might raise their position to such a level as they could, in effect, be trusted to vote in the right direction. Moses makes clear that during the Second Empire, feminist movements became "bourgeois and liberal in interest as well as ideology". ${ }^{78}$ They began to demonstrate a clear bias against the rural poor and artisan/peasant communities and reinforced tendencies towards statism. The state was in this case clearly anti-feminist, its approach built on urban conceptions of what women's rights ought to be, and myths surrounding peasant family values and an assumed reactionary politics. From 1789 the state held out the promise of delivering full emancipation in France, but women were not given the vote in France until 1945.

\footnotetext{
${ }^{76}$ Moses [1984], p. 137.

${ }^{77}$ d'Héricourt [1981].

${ }^{78}$ Moses [1984], p. 172.
} 


\section{Pacifism and Bellicose Chauvinism}

Understanding changing attitudes to war in nineteenth-century France is important for two reasons. First, we see that attitudes towards the use of military force evolved with its industrialisation. Secondly, what we find is that the left becomes slowly less enthusiastic about the use of force as it becomes clearer that the state is no longer controlled by the people. Finally, the change from a conscript citizen army to a professional military force removed the traditional identification of the army with the patrie. The following narrative thus echoes Proudhon's concerns in the previous chapter, and is also a preface to the more detailed exploration of his attitude to military force in chapter five. The story begins with the revolutionary enthusiasm for war and ends with the military repression of the Paris Commune. This period witnesses the rise of a peace movement on both the left and right to which Proudhon also responds. By the 1870s, the state, originally championed by the left in all its technocratic, and modernist militarism, had come to resemble Frankenstein's monster. It was out of the control of the people who had given it life.

Prior to the mid nineteenth century, peace was a largely liberal preoccupation. Liberal argued that if only free-exchange and strong republican government were universalised then a universal peace would be achieved. For the British liberals supporting the Holy Alliance was central to this vision since they saw, and quite rightly, the left and their professed aim of overturning the 1815 treaties as a threat to the burgeoning liberal constitutional order. On the left, the story was markedly different. From the turn of the century war and revolution had come to be seen, by both the left and the right, as one and the same thing. Moreover, as Philippe Darriulat has argued, “[v]ouloir la paix, c’est abdiquer face aux puissances absolutistes, s'engager dans une politique de concessions". ${ }^{79}$ Peace was inherently conservative, therefore, and so war infinitely radical. Babeuf, for example, was among the first to understand history and future social progress in terms of a war between rich and poor. ${ }^{80}$

\footnotetext{
${ }^{79}$ Darriulat [2001], p. 20.

${ }^{80}$ Pilbeam [2000], p. 29 Babeuf was also denounced and guillotined during the Thermidor, but remained an idol of the Jacobin left for years to come.
} 
More conventional propaganda was nationalist in emphasis. France, the first nation state, had a 'mission civilisatrice' in Europe. This project sought liberty and self-government for the all the people of Europe, through their emancipation from the clutches of the aristocracy. Therefore the Revolutionary Wars were not only necessary, but right and providential, messianistic and so forth. Submitting to the powers of reaction was to deny the inevitability of history and the divinity of the French revolutionary project. Conversely, the French right who concurred with Metternich that the European balance of power was crucial to liberty, argued that pacifism and statism were the key to protecting markets and access to them. This nevertheless involved crushing the left at home wherever possible, and gave birth to a form of liberal internationalism that saw the potential for peace not in power politics and the balancing of material power, but in the development of free-market capitalism protected by a system of constitutionally balanced and limited sovereign states.

By the mid 1830s, French republicans had come to divide the world in three. The English represented the rich and individualism, and thus to be avoided by la douce France at all costs. The Russians, on the other hand, typified all that was wrong in the present because they were the arch-relics of the Europe's pre-revolutionary past. Russia stood for unchecked autocratic power and the absence of civic constitutionalism. Only France stood for the people, and only a strong, secure and republican France held any hope for Europe. France's citizen army was the instrument of this promise.

The rise of a distinctly anti-militarist and pacifist policy on the French left begins around 1848 - the year of near universally violent European revolutionary uprisings. Lamartine, the new republican French Foreign Minister, pursued a conciliatory and pacifistic foreign policy in an attempt to assure the rest of Europe that the latest and most self-consciously socialist French Revolution would not be followed by the wars that followed the previous one. ${ }^{81}$ Nevertheless, republicans still viewed European change as a fundamentally French

\footnotetext{
${ }^{81}$ Darriulat [2001], p. 171. cf. Cabanel [2004], pp. 510-511.
} 
mission and this ethnocentrism was reflected in the majority of French newspapers and periodicals as I discussed in brief in the previous chapter. ${ }^{82}$

Nevertheless, Proudhon's attitude towards the Italian wars was symptomatic of a change in the relationship between the French and her military. ${ }^{83}$ The success of La Grande Arme and the levée en masse following the 1789 revolution rendered the army the veritable idol of French republicanism: if the people were the new God, the army was His sword, but by the mid 1860s the French state and her military had come to represent the forces of reaction since it was now the instrument of Louis Napoleon in cahoots with the church and the bourgeoisie. Even Louis Blanc, our arch Jacobin chauvinist, argued that French adventurism in Italy was "international donquixoteisme”. ${ }^{4}$ By 1871 , with the crushing of the Paris Commune there was no question; the army was now anti-social(ist) and should only be understood instrumentally. The transformation in the relationship of the intellectual left to the state was profound. From then on the Republic no longer had revolutionary potential. It was clearly the instrument of reaction. ${ }^{85}$

With left-wing disenchantment with the military came a feeling, reflected in the work of Blanc among others, that work ought to replace the military as the site of valour. He even proposed a Legion of Honour of Work to "elevate natural leaders to heroic action” in the economy. ${ }^{86}$ He held these views in parallel with his views on nationalism which were fundamentally concerned with redrawing the map of Europe to suit France, and while in exile his "apology for violence” couched in nationalist terms "was based upon a clearly stated economic determinism.”87 England ought to have been attacked and conquered, and the Mediterranean ought to have been made a "French lake" with the colonial project

\footnotetext{
${ }^{82}$ Darriulat's analysis of the French left is drawn largely, though not exclusively from the French republican press of the nineteenth century. The same key source Proudhon used while in exile. He makes the argument that in the absence of clear party divisions and of ideological cohesion, republican factions would coalesce around publications. Darriulat [2001], p. 9.

${ }^{83}$ Ibid., p. 241.

${ }^{84}$ Ibid., p. 246

${ }^{85}$ Ibid., p. 281.

${ }^{86}$ Lobère [1961], pp. 39-40.

${ }^{87}$ Ibid., p. 51.
} 
in Africa extended. ${ }^{88}$ Blanc was by no means alone. But Proudhon did not follow him here.

On the liberal right, as opposed to the Catholic right, after some forty years of uninterrupted European peace, there rose a small but vocal consensus that the erosion of tariffs, trade and industrialisation would bring peace and prosperity to the world. At precisely the time that the European powers were conducting their experiments in the industrialisation of warfare, the Cobden-Chevalier Treaty sought peace between France and Britain through a reduction of tariffs and free trade. Richard Cobden and his colleague John Bright, were also vocal critics of British foreign policy and believed that in an age of free trade, war was not only deleterious to the national interest, it was also economically insupportable. With the onset of the Crimean War, their belief that the people would forsake war for the prize of free trade and economic prosperity took a serious knock. The sheer excitement the first overseas campaign for almost a generation generated in the European population surprised many. For liberals, states were mainly to blame, while the people were simply labouring under false ideas. ${ }^{89}$

Pacifism on the French left took another hue. Pierre Leroux for example, a contemporary and in some ways far more radical and revolutionary than Blanc, believed that the future of the revolution relied on a fundamental denunciation of what he saw as the "right of force". The evolution of human sensibilities were such that any future social cohesion must be premised on principles of rationality and humanity. ${ }^{90}$ French society ought to move out of this period of belligerence and discover a pacifism that was more suited to her refined nature. Leroux articulated a view of a pacifying and progressive history and one in which the "anti-progressive principle of violence" was socially instructive as opposed to historically providential.

This new breed of anti-militarism understandably left the old left in something of a difficult position. Rather than abandon war, for this would hamstring any statist revolutionary, war had to be rationalised instrumentally and materially if it were to have

\footnotetext{
${ }^{88}$ Ibid., p. 53.

${ }^{89}$ See Howard [1978] for an excellent discussion of this episode in liberal theory.

${ }^{90}$ Le Bras-Chopard [1986], p. 346.
} 
any strategic importance. In sum, if it were to be recognised at all, it would have to be qualified as a necessary evil in the pursuit of better ends: "l'instrument de l'émancipation des peoples et de la lutte contre le despotisme." ${ }^{91}$

Proudhon was caught right in the middle of this change. As I will show in chapter five, Proudhon believed the pacifists were feminists who were emasculating the French and the left. He had nothing but scorn for the liberal internationalists who's laissez faire attitude, he argued, was a pretext for greed. Much like Blanc, he saw the industrial working class as the new hope but because the likes of Blanc and the nationalists were cajoling the people into wars he was utterly dejected about the revolutionary potential of the working class. This changed slightly in the final years of Proudhon's life and his mutualism was given impetus by the actions of the Manifesto of the Sixty and the flexing of working class muscle in Paris. This is the subject of chapter six. Here I will close with a brief look at the evolution of nationalism and show why, by the end of the 1860s things were beginning to change.

\section{Nationalism and Internationalism}

Nationalism ties the history of the left to the state, the state to religion and religion to socialism. Underpinned by the revolutions in military technology and the financing of the state, together these movements had profound shaping effects on how the French understood their place in post-Revolutionary Europe. By way of synopsis it is worth starting with an important recent work by David Bell in which he has argued that "Nationalism, in France at least, cannot begin to be understood properly without reference to religion." ${ }^{92}$ Hazareesingh has also argued that

The national question was maintained at the centre of political debate as a result of the fragmentation and polarization of French society, and its reflection in the ideological character of its political discourse. The more divided a political community, the greater the political appeal of the idea of

\footnotetext{
${ }^{91}$ Becker [2004], p. 524.

${ }^{92}$ Bell [2001], p. 24.
} 
unity; the greater the appeal of unity, the more the urgent need to find a normative language in which this goal could be formulated. Nationalist ideologies performed this function throughout the process of national and cultural integration in France, which was conducted through the development of centralized state institutions. ${ }^{93}$

This integration of the nationalist with statist discourse, within the context of religious and social change and a new political millenarianism, gave us the nation state in France and a blueprint for most of Europe. What is important, as Bell shows, is to understand this movement within the corresponding context of the transformation of religion, and the secularization of modern French society. It ought also to be understood within the context of the unifying tendencies of the French Revolution and the violent means used to achieve them. French cultural, historical and linguistic regionalism was stamped out from the turn of the century. It is worth recalling that Proudhon's home town of Besançon was placed under siege by Napoleon in 1813.

Conversely, the universality of the Declaration of the Rights of Man, and the fervour with which the Revolution was exported, produced another awkward tension within French politics. Difference could only be recognised within the parameters of a universalisable civil code. Constitutional government was employed to create a distinct and homogenous civic nation in which all other differences were extra-political and left to the social realm. This was eloquently and succinctly described by Marx in the essay 'On the Jewish Question' - the title adequately illustrating the link between religion and nationalism, and the content investigating the role of universal rights in enforcing particular capitalist social relations. ${ }^{94}$

It is important to make the distinction between left-wing and republican patriotism and bourgeois nationalism. The latter saw the French state as an organic whole and was influenced by the works of the Catholic theocrats. ${ }^{95}$ The left saw the state in more political and institutional terms and thus their feelings for la patrie were more to do with

\footnotetext{
${ }^{93}$ Hazareesingh [1994], pp. 127-128.

${ }^{94}$ Marx [1977].

${ }^{95}$ Weil [2004].
} 
the glory of the Revolution and France's mission civilisatrice rather than with any organic feeling of association.

On the other hand early socialists such as Louis Blanc followed Rousseau almost verbatim on the matter of la patrie. He believed that "[t]hose who wilfully and actively opposed the new regime must either emigrate to another country of suffer the legal consequences." 96 He also believed that "[i]n the matter of education [...] centralization cannot be too strong.” La Patrie ought to be the central guiding principle of a national and secular education based on an understanding of the history of the French nation and an almost deistic conception of her historical rectitude. ${ }^{97}$

This nationalist and pedagogical approach to history was also evident in the work of Michelet who argued that history gave Frenchmen their mission and the Nation was the vehicle for realising universal emancipation. The language was both messianic and religious and for him at least le peuple were the new messiah. Darriulat puts it well when he says that “[l]'ethnocentrisme français s'affirme bien alors comme la caricature naturelle de l’universalisme auquel il fait référence."98

As we have seen, the people's relationship to the military was undergoing something of a mini revolution. At the same time the industrialisation of society produced distinctive class cleavages, and by the 1870s the working no longer saw the state and nation as one and the same thing. It is thus unsurprising that during the Second Empire the legal state became politicised and looked to the discourse of nationalism to re-legitimate itself. The Rousseauean homogeneity of the nation state and the myth that it might reflect the interests of the people was becoming less tenable. Conceptions of class, nation, law and historical destiny gave this politicisation a new language, and a militant one at that. But vitally, each of these processes began to consolidate what France was and gave her a distinct internal as well as external political aspect. ${ }^{99}$

\footnotetext{
${ }^{96}$ Lobère [1961], p. 30.

${ }^{97}$ Ibid., p. 40.

${ }^{98}$ Darriulat [2001], p. 139.

${ }^{99}$ Ibid., p. 249.
} 
This process was exacerbated therefore, by republican pronouncements that became trapped between their internationalism and their nationalism. How can one claim that the historical fulfilment of the Revolution is the French nation state and also recognise that the French state is governed by the forces of reaction? How could the French revolutionary project be both nationally emancipatory, proclaim the right of all to national self-determination within the parameters of the nation state, and also claim to be progressively internationalist which would effectively mean the erosion of the very same borders? As the century wore on, and as the left became even more disillusioned with the state as an instrument of progress, nations was all that was left to demarcate the limits of working class identity. The crushing of the Paris Commune eroded faith in the ability of the nation-state to deliver left wing goals, and it became clear where power now lay. Of course, by this point it was too late.

Again, the election of Louis Napoleon Bonaparte to the Presidency of the Second Republic on the 10 December 1848, was the first stage in a complex psychological revolution on the French left, which ended with the coup d'etat of the $1^{\text {st }}$ of December 1851 and the birth of the Second Empire. Louis Napoleon reflected and rode the contradictions in French politics. Here was a person elected for his family name, and for the reinvigoration of national pride after a period of international submission. ${ }^{100}$ He tried to be all things to all people and failed. Within ten years Napoleon had destroyed the fragile European peace, and then the international balance of power in Europe. By this point, the nation state had been born and cloned throughout Europe with varying degrees of success and imitation. It was the Prussians that were to perfect the French design.

\section{Conclusion}

The aim of this chapter has been to show how French social theory in the latter half of the nineteenth century was almost entirely inward looking. This stands in stark contrast to the revolutionary internationalism of the early part of the century. By the 1860s, the time around which Proudhon penned his works on European international relations, most saw

${ }^{100}$ Becker [2004], p. 523. 
international relations as explicable by domestic political concerns or simply ignored them altogether. It was clear that the evolution of the nation state, and what to do about the direction it was taking, preoccupied most social reformers and revolutionaries.

Thus, when Proudhon came to write about world politics, the vast majority were concerned with domestic politics. Changing attitudes towards war and the national army were the outgrowth of domestic-led industrialisation of warfare. Science and philosophy, the doctrines of nationalism and statism, all trumpeted the inevitable progress of society and the fulfilment of social destinies. Few applied these ideas to the international concerns. Doctrines of national unity and legal universalism clashed with social difference and overseas injustices, but the international system was never part of the explanation for the domestic issues. For example, feminism, also taking from science and using its arguments against the philosophers of right, provided a key critique showing up the masculine and patriarchal nature bourgeois legalism, but the role of the army, the state and the structuring pressures of the international system simply did not feature in their arguments. The resignation that followed the disappointment of 1848 turned the radicals inwards, or prompted abstract universalism. Thus, when Napoleon lurched into Europe and sparked a rupture in the European balance of power, no one had the arguments to criticise him given the contradictory nature of French society and near universal subscription to statism. I will show that Proudhon was a key exception. 


\title{
Chapter 3
}

\section{Providence, Imperialism and the Evolution of European Political Thought}

\begin{abstract}
A social system which is dying, a new system whose time has come and which is in the process of taking definitive shape, this is the fundamental character which the general course of civilisation has assigned to the present age. ${ }^{1}$
\end{abstract}

\section{Introduction}

This chapter must accomplish three things. The main task is to focus in depth on a particular aspect of the philosophical context of Proudhon's time in order to provide an understanding of the dominant ways of approaching world politics amongst the century's most important political philosophers. I focus on the work of Rousseau, Kant and Comte and how they influenced one another and Proudhon. Secondly, by providing this discursive context I will show that the dominant ideas used at the turn of the century to understand interstate or international relations are located in the philosophy of history of these writers. This philosophy was deeply providentialist and teleological in character and was used to justify the imperialism that was carried out in its name. For Rousseau, Kant and Comte, the possibility of realising progress to the ideal state demanded war; war was therefore providential; and only via this process would states become demarcated and properly organised internally. Finally, I will show how each of these writers built on and developed the thinking of his predecessor(s) in significant ways so that I can show how Proudhon develops their thought in turn. I will focus on how each writer builds his political philosophy up from basic, normative, ontological and

\footnotetext{
${ }^{1}$ Comte [1998a], p. 49
} 
epistemological assumptions to their approach to war and peace. This method is replicated in the following chapters on Proudhon.

The chapter is also designed to undermine Amoudruz' claim that while Proudhon might have been a canny "petit paysan" and an astute journalistic commentator, he lacked the intellectual depth of his more illustrious contemporaries. ${ }^{2}$ By outlining their thought in some detail I will also be able to show how philosophically sophisticated Proudhon was in turn. This philosophical context is also vital in terms of setting the scene for explaining Proudhon's normative advocacy of the entrenching of the European balance of power, radical federalism and socialism as a cure for the ills of the nineteenth century. Finally, and related to this, if Amoudruz is right to claim that what actually transpired in the 100 years after his death was the "inverse" 3 of what Proudhon had argued for, understanding what everyone else was arguing for will also provide a useful yardstick for the normative analytical and philosophical value of his arguments.

I argue that Rousseau, Kant and Comte are the three key influences on Proudhon's thought throughout his life - as they were on the thought of many. It is worth noting here that, despite claims to the contrary, Hegel had little if any influence on Proudhon's later thought. Indeed, it is unfortunate for our understanding of the origins of Proudhon's ideas that so much has been made of his assumed Hegelianism. ${ }^{4}$ On the other hand pages and pages of evidence can be found in support of the argument that Rousseau, Kant and Comte were the main influences during this period. Rousseau's influence on the thought of nearly all who followed him, particularly Proudhon, is obvious to even the most superficial readings of Proudhon's thought, and Noland has amply demonstrated the links between the two. ${ }^{5}$ As I will show in chapter six, Rousseau echoes on nearly every page he wrote regarding federalism, either as a foil for one of his own arguments, as the object of scorn, caricature, or all three. This was by no means a new engagement. Rousseau's work is engaged with throughout Proudhon's oeuvre.

\footnotetext{
${ }^{2}$ Amoudruz [1945], pp. 20, 78.

${ }^{3}$ Ibid., p. 151.

${ }^{4}$ See, for example, De Lubac [1948]. De Lubac also places Kant at the heart of Proudhon's thought. For an analysis of the relative absence of Hegel in French social theory at this time see Kelly [1981].

${ }^{5}$ Noland [1967].
} 
Proudhon claimed to have been reading Tissot's translation of Kant's Critique of Pure Reason from as early as $1839 .{ }^{6}$ But it was not until Tissot published a translation of the Metaphysical Elements of Right (1797) in 1853 that Proudhon became familiar with Kant's political philosophy and his philosophy of history. ${ }^{7}$ Proudhon's notebooks attest to the depth of his engagement with this work and how important it was for the formulation of his ideas for La Guerre et la Paix. For example, Edward Castleton unpublished transcriptions of Proudhon's notebooks show that Proudhon was using Fourier's critique of rationalism against Kant to show that rationality alone cannot guarantee order and that “[i]l faut chercher d'autres garanties”. ${ }^{8}$ This is what Proudhon sets out to do. Haubtmann also tells us how Proudhon went to visit Tissot to talk about Kant’s work in June 1856 around the time he began work on De la Justice. Given the numbers of people that were visiting and writing to Proudhon for moral advice, Proudhon was coming to see himself a "moraliste consultant", and then claimed in 1859 that De la Justice would be "[u]ne sorte d'encyclopédie dont le principe, la loi, la méthode, la fin, est le droit”. The parallels with Kant's work are striking here. What I will show is that the directions in which Proudhon took his analysis would be antithetical to the Kantian project.

How does Comte's work influence Proudhon? In the introduction to the Marcel Rivière edition of Proudhon's De la Création de l'Ordre dans l'Humanité (1849), Bouglé and Cuvillier make it clear that Comte's System of Positive Philosophy is a key influence on the work but remains largely un-cited. The influence lies mainly in Proudhon's use of Comte's relational ontology and the famous law of the three stages. ${ }^{10}$ They also note that in the second edition to the work, Proudhon himself notes the resemblances between the two works but claims he discovered the ideas on his own. ${ }^{11}$ The editors draw out striking similarities and note that Proudhon's otherwise faithful referencing is not evident in this instance. The editor of the Marcel Rivière edition to Proudhon's Philosophie du Progrès

\footnotetext{
${ }^{6}$ Vincent [1989], p. 62.

${ }^{7}$ This translation also includes 'What is Enlightenment?' and Perpetual Peace', 'Theory and Practice' and the 'Contest of the Faculties', which almost amounts to a full collection of Kant's political writings. Kant [1853].

${ }^{8}$ Proudhon [unpublished].

${ }^{9}$ Haubtmann [1988], pp. 30-57. Haubtmann here also discussed the depth of Proudhon's engagement with the Crimean campaigns during this time.

${ }^{10}$ Bouglé and Cuvillier [1927], p. 17.

${ }^{11}$ Ibid., p. 18.
} 
(1853) also notes that Comte’s "Catéchisme Positiviste” is "exactly contemporary" and his earlier works are evident here also. ${ }^{12}$

Interestingly, in 1854 Auguste Comte sent complementary copies of the first two volumes of his Système de Politique Positive to Proudhon with an odd invitation to join him in proselytising the positivist Religion of Humanity, which Proudhon declined for many of the same anti-dogmatist reasons he gave in turning down a similar invitation from Marx and Engels. ${ }^{13}$ As Haubtmann’s readings of Proudhon's notebooks shows, Proudhon read the volumes in some detail. This fact is important since the System of Positive Politics contained many of the arguments of Comte's earlier works, which were by then widely known and discussed. Indeed, in the preface to volume one of this work, Comte claims that this was his most important work, his career having been "homogenous throughout; the end being clearly aimed at from the first." 14 As if to prove this, Comte's "Plan of a Scientific Work Necessary for the Reorganisation of Society" (1822-1824) or what he called his 'Opuscule Fondamental', the embryo of the larger work which he sent to Proudhon, and three other key early essays, are included as an appendix to the fourth volume. What will be made clear in the chapters to follow is that the sociological content of these works made a deep impression on Proudhon's thought.

However, what is perhaps as important for our purposes in this chapter, and the contextualist methodology employed in the thesis, is the influence of Kant on Comte, and Rousseau on both. There is a clear and explicit intellectual genealogy in which Rousseau influences Kant and the writings of both have a huge effect on Comte. This development is important also in order to place Proudhon back within the key intellectual debates of his time.

Rousseau's influence on the ideas and work of Kant is well known. Anecdotally, a portrait of Rousseau is the only picture said to have decorated Kant's home, and he read Emile in one sitting and claimed to have been profoundly shaken by it. The Social

\footnotetext{
${ }^{12}$ Ruyssen [1946], pp. 15-17.

${ }^{13}$ Haubtmann [1980], pp. 183-196. Frank Manuel also notes that Comte wrote to Alexander II, the General of the Jesuits and Mehemet Ali asking for support. A motley mix if ever there was one.

${ }^{14}$ Comte [1968a], p. ix.
} 
Contract was an equally seismic influence on Kant's thought. But as Cassirer has influentially put it, Kant

demanded definiteness and accuracy in ideas and clarity and perspicuity in their architectonic construction. He had to think Rousseau's ideas further, and he had to complete them and give them a systematic foundation. And in so doing it developed that this foundation led to a problem of absolutely universal significance, to a problem that included a genuine "revolution in men's way of thinking." Only through a critique of the entire "faculty of reason” could Kant solve the conflict that had inspired Rousseau in his fight against the philosophes; only in this way could he create that wider and deeper idea of “reason” which could do justice to Rousseau's ideas and incorporate them in itself. ${ }^{15}$

The most striking evidence of Kant's reworking of Rousseau can be found in his essay the 'Idea of a Universal History with a Cosmopolitan Purpose' (1784). Here, God and man's place in the cosmos were as central to Kant's metaphysics as they were to Rousseau's, as I will show. While Rousseau sought to revolutionise our ideas about the social order, Kant and Comte, having witnessed the effects of the Revolution first hand, sought the opposite - to stabilise, categorise and order our ideas and as a direct consequence, it was hoped, the social order.

Then, in December 1824, Comte confided in a letter to his Saint-Simonian friend Gustave d'Eichatel, who had recently translated Kant's 'Idea of a Universal History' and fragments of the Critique of Pure Reason for him, that, “[a]fter reading this, I hardly find ... any value [in my own Opuscule Fondamental] other than that of having systematised and fixed the conception sketched out by Kant without my knowledge". ${ }^{16}$ While there is a characteristic lack of modesty in this statement, one that seems to echo Proudhon's claim regarding Comte's influence on him, the similarities between the two essays are indeed

\footnotetext{
${ }^{15}$ Cassirer [1963a], p. 59.

${ }^{16}$ Pickering [1993], p. 291.
} 
striking. Both Comte and Kant were dealing with similar issues and both had similar intellectual and social influences on their work.

The 'Idea' made such an impact on Comte's thought that Pickering argues it is possible to see an almost immediate decline in the influence of Condorcet, who epitomised French Enlightenment thinking, on his thought. Referring to Kant she continues that "[n]ever had he [Comte] lavished so much praise on another thinker". ${ }^{17}$ D’Eichatel subsequently managed to convince Comte to make his philosophy of history even more deterministic by leaning on Kant's teleological propositions and theories. In his later essay "Philosophical Considerations on the Sciences and Scientists", which I will discuss briefly below, Comte explicitly aimed to "remove all doubts regarding the validity of the law of three stages” using Kant as validation and inspiration. ${ }^{18}$ There were of course important and hugely influential differences between the two that were to be of equal influence on Proudhon, as I will show.

Comte criticised Rousseau's Social Contract for being too "hypothetical”" ${ }^{19}$, metaphysical and too influential in generating the critical rational individualism that he loathed and which was antithetical to Comte's organic conception of society. But he too uses a variation of the concept of the Civil Religion so central to Rousseau's own writings and devises his own Religion of Humanity - divested of its civic and legalistic framework. The utilitarian role of religion in the systems of each of these men ought not to be overlooked. Nor, as I will show, should we overlook how deeply they believed in divine providence (or a secular theodicy in the case of Comte) - particularly in international relations.

In broad outline, my argument is that Proudhon's critique of Rousseau provided him with the normative impetus for his federalist anarchism; Kant provided him with the philosophical tools he needed to underpin it, and Comte provided him with the sociological method and his realist relational ontology. This ultimately translated into anarchism. However, this contextual chapter will also show that Rousseau, Kant and

\footnotetext{
17 Ibid.

${ }^{18}$ Ibid., p. 335.

${ }^{19}$ Ibid., p. 126.
} 
Comte provided a sizeable part of the intellectual justification for nationalism, statism and imperialism. ${ }^{20}$ Divine providence, and the atheistic alternative of deterministic teleology in Comte, was central to their ideas. This providential justification for political projects is perhaps the key context for the origin of Proudhon's ideas. As Noland has argued, Proudhon juxtaposed two types of history writing, one "providential" the other "philosophic", and placed himself firmly in the latter camp, while he criticised the folly of those who took the perspective of the former. ${ }^{21}$ The details of Proudhon's philosophy of history will be made clearer in the chapters to follow. Here it is important to understand the context of his thought in order to show how far Proudhon's ideas differed from those of his contemporaries.

To show this, the chapter is divided in three. In part one I discuss Rousseau's conception of the emergence of social justice and illustrate how his religious providentialism translates into the political philosophy of the Social Contract. This will contribute to the analysis of the previous chapter in explaining the religious messianism of the French Revolution and the intellectual underpinnings of the French left in the nineteenth century. In part two, I turn to Kant's critique of Rousseau and show how he removes the passions from Rousseau's thinking and replaces them with reason. I then show how this relates to his philosophy of history and, again, his understanding of the providential role of God therein. For both Rousseau and Kant, God's role, while radically diminished, is nevertheless central to justifying a particular theory of the state and understanding why war has been so central to its historical development.

Comte's not-so typical revolt against reason is interesting because he was also the father of positivism. Understanding how Comte followed the likes of Charles Fourier in reinstating the affections and sentiments at the heart of social theory is crucial here. Comte's new sociological and positivist methodology is a vital development in the history of European thought. However, I will show how Comte's reliance on the Catholic theocrats for their conception of order and history had a profound effect on his politics; an effect that is striking in terms of the emergence of ideas so similar to Kant's, despite

\footnotetext{
${ }^{20}$ Cf. Tuck [2001].

${ }^{21}$ Noland [1968].
} 
such radically different ontological and epistemological starting points. It is from here that the story of Proudhon's later thought will then begin.

\section{The Origins of the 'Civil Religion' in Rousseau’s Thought}

The analysis I provide here will seek to provide an explanation for the need for the "Civil Religion” in Rousseau's Social Contract. This will help me achieve four additional goals. First we will be able to better understand the use to which it was put by the revolutionaries. Secondly, this discussion will help explain the type of sovereignty Rousseau advocated. Third, I will show that the Civil Religion was crucial to tempering the stark materiality of civil society and that it also clothes the state in providential robes. Finally, I will also show that the Civil Religion is a necessary component of Rousseau's thinking because, even though an anti-cleric, he was no atheist.

The section is divided in the following way. First, I turn to Rousseau's debate with Voltaire over the nature of Divine providence in history. Second, I turn to Rousseau's theory of prelapsarian human nature (i.e., human nature before 'the Fall') and the role of evil in the formation of civil society. Third, I show how civil society corrupts and how it is only if civil society can be constructed in such a way as to re-approximate our true natures that it can be said to be moral and just. What we find is that for Rousseau this realignment of civil society with our true natures would be the realization of divine providence, an explanation of evil in the world and a justification for the state - themes that are also central to the work of Kant and Comte later. Rousseau's Sovereign, the people, becomes a secular divinity, and the civil state (the institution through which sovereignty is realised) becomes heaven on earth. The pessimism which saturates Rousseau's work notwithstanding, his belief in God links his theodicy, his progressivism, his understanding of human nature and the social contract. As I will show, in the final analysis it also becomes the justification for imperialism. 


\section{Rousseau vs. Voltaire}

The story begins, as does this thesis, with Voltaire's stunning poem 'The Lisbon Earthquake' (1755). It can, and has been read a number of ways - as has most of Voltaire's work. However, what is abundantly clear is that there is a basic ambivalence about the role of God in society and a disillusionment with the promises of Enlightenment reason. But as historians of the period have pointed out, Voltaire was not merely expressing a Europe-wide anguish derived from the seeming randomness of death, particularly in such a centre of culture as Lisbon, he is also engaging in a serious philosophical debate through this short poem. This debate can be seen as having encompassed the whole of the philosophy of the Enlightenment. Simply put, what role does God have in society and nature, what role do the discoveries of science have in our moral universe and is this world the best we can expect or is something better coming?

The poem opens with an entreaty to Pope's classic thesis that this is the best of all worlds, a cry from the heart to show that things can not be right with the world and if things are not right with the world, what is God punishing us for? Voltaire's God seems either infinitely cruel or out of control. On the other hand, science and the laws of nature, disjointed from the basic ideas of providence, seem to be utterly empty.

Rousseau took exception to Voltaire's poem and penned his reply in August 1756. At this time, Rousseau was developing themes that were to come to dominate the Social Contract (published in 1762, but germinating as early as the late-1740s and well under construction by at least 1759). ${ }^{22}$ Rousseau's reply to Voltaire is also stunning in terms of the statement of his devout belief in God. The subsequent debate thus centred on who could provide the best account of the nature of Divine providence, while bearing in mind reason and free will and the new discoveries of science. As Victor Gourevitch has argued, the debate ultimately turned on whose was the "more consoling" theory, Voltaire or Rousseau's? ${ }^{23}$

\footnotetext{
${ }^{22}$ Hampsher-Monk [1992], p. 175.

${ }^{23}$ Gourevitch, Victor. [2001], p. 200.
} 
Pope had argued that despite the calamities of nature and the failures of reason "all is well”. What this meant was that despite the chance machinations of life, proof of God's plan for life could still be divined through the processes of reason and the understanding of natural laws. In fact, if we were to do science properly, he argued, we would see that all is in fact well. The laws of nature were the laws of God and thus whatever happened was God's will. Rousseau disagreed, as did Voltaire. Both argued that the totality of God's plan was beyond human comprehension, and there are no empirical proofs of God's design. But in his response to Voltaire, Rousseau argued the following:

The true principles of optimism ["all is well”] can be drawn neither from the properties of matter, nor from the mechanics of the universe, but only by inference from the perfection of God, who presides over all; so that one does not prove the existence of God by Pope's system, but Pope's system by the existence of God, and the question regarding the origin of evil is, without a doubt, derived from the question regarding Providence. ${ }^{24}$

Thus providence and theodicy were not only theological questions, but historical, political and social ones too. But it was nevertheless vital not to get rid of religion altogether. "[O]ne cannot too forcefully attack the superstition that disturbs society, nor too much respect the Religion that upholds it”"25 he argued. Nor is this a contradiction, or cynical caution. This represents exactly the conundrum of eighteenth and early nineteenth century thought. What is right and what holds, or should hold, society together and how does it? And what place for individual reason within the religious order? As he continues,

But, like you [Voltaire], I am indignant that each individual's faith does not enjoy the most perfect freedom, and that man dares to control the inner recesses of consciousness which he cannot possibly enter; as if it depended on ourselves to believe or not to believe in matters where demonstration has no place, and reason could ever be enslaved to authority. Are the Kings in this world then inspectors in the next? and have they the right to torment their

\footnotetext{
${ }^{24}$ Rousseau [1997e], p. 240.

${ }^{25}$ Ibid., p. 244.
} 
Subjects here below, in order to force them to go to Paradise? No, all human Government is by its nature restricted to civil duties; and regardless of what the Sophist Hobbes may have said on the subject, when a man serves the State well, he owes no one an account of how he serves God. ${ }^{26}$

The purpose is thus to demarcate the respective spheres for reason and morality in the face of a widely viewed Hobbesian materialism, and to try to show that this search for the foundations of reason and moral authority is also part of God's plan. Rousseau goes on to argue that what is needed is "a civil profession of faith" to work out the relationship of men to one another and to sanctify this relationship as God's will. “This work, done with care, would be the most useful book ever composed, it seems to me, and perhaps the only one needful to men."27 There is a wry disingenuousness in then asking Voltaire to write this work when he was in all probability actually composing it himself. It is to the Social Contract that I will now turn.

\section{The Social Contract}

In the "Discourse on Inequality"28 Rousseau famously argued that the evils of modern civilization were proof of man's fall from a pre-social grace and it was our task to make the best of a bad world. In this the laws of reason could not help us, for the laws of reason had unhooked us from our pre-social natural goodness by reducing morality to material interest in the manner of "the sophist Hobbes". For Rousseau our natural goodness was God-given, and it was thus our moral and providential duty to re-discover it in the fullness of time. This could be achieved, he argued, by instituting a particular type of political community that would solve the problem of our civilized fall from grace.

Despite familiarity with the anthropological works of his time, in the Social Contract Rousseau turned to logic to devise the ideal political system and the principles that ought to underpin it. ${ }^{29}$ The aim was to turn Hobbes on his head. If man were as naturally

\footnotetext{
${ }^{26}$ Ibid., p. 244 (emphasis added).

27 Ibid., p. 245.

${ }^{28}$ Rousseau [1997f].

${ }^{29}$ Rousseau [1997c].
} 
avaricious as Hobbes had claimed, there would be no reason why he would have created the social pact in the first place. And even if he did, Rousseau argued, it would soon break down if men were that evil anyway.

Rousseau put the question a little differently. Like Hobbes, Rousseau argues that it is "necessary" to have "true ideas" about a social state that never existed in order to conceive of the logical grounds on which to build a new social order. But Rousseau begins from the position that the state of nature was quite a nice place, even if it was based on an a-social individualism. On contracting, society breaks down Man's individuality and the social crisis ensues. But rather than jettison all features of life other than political authority to ensure order, retaining religion was one way in which to bring morality back into politics.

Approaching the question of morality from within the discursive framework of theodicy allowed Rousseau to broach the question of temporal and social evil from the perspective of a transcendental plan outside of history, rather than any innate human maliciousness. This allowed him to hold fast to the idea of man's innate goodness prior to the social 'fall' and then to see in the ideal political community the working out of God's plan for humanity. Nearly every 'hidden hand' argument of the Enlightenment and beyond leans in some way on this type of formulation.

Rousseau was therefore quite clear that the Social Contract is not something one can prove by logical or empirical fact. Rather it was something that could only be proven by our "sentiments of sociability" ${ }^{30}$, sentiments that can only be understood by a true extrasocial understanding of one's true individuality. Thus Rousseau argued that our innate goodness was recoverable and that we could and ought to be able to feel it within us. Making laws correspond with this innate feeling was the purpose of civil society.

Following Montesquieu, ${ }^{31}$ Rousseau argued that our feelings, provide laws with their spirit and it is precisely because this varies across geographical space that we can account

\footnotetext{
${ }^{30}$ Ibid., p. 150.

${ }^{31}$ Cf. Montesquieu [1989].
} 
for cultural and political difference. Nevertheless, the Social Contract does not need history or geography in order to justify it in fact, this would seem to undermine its purity. The Social Contract is the product of logic derived from self-knowledge. It is principally for this reason that Rousseau was also so bitterly anti-clerical. He believed that the dogmas of religion had become the corrupted tools of oppression rather than fulfilling their promise of spiritual enlightenment aimed at helping us closer to our maker. The hierarchies and inequalities of the social order were the product of bad laws, selfish exploitation and repression, all of which are the product of poorly organised political communities. In fact, civilization was the result of particular individual interests, rather than being the expression of, and thus in the interests of, the General Will.

Central to recovering the General Will was the recovery, through a natural education, of man's innate individual goodness. Pace Hume and Locke, Rousseau argued that "[t]he self is not a datum of the sense and can never be understood as the mere product of sense data. It is an original activity, and [following Descartes] the only evidence of such activity available to man. And this spontaneity of the self, not its receptivity, is the mark of the Divine." 32 Society can thus teach us nothing about our true selves because our true selves are precisely what society has corrupted. It is only self-knowledge, a self knowledge derived from proximity to nature (no less God's creation of course) that can be of educational value. ${ }^{33}$

While individuality was God-given, it was a remnant of a pre-social order that it was nevertheless impossible to recover. As soon as human's associated we began the decline into civilisation. The aim of the social contract is thus to " $[\mathrm{t}] \mathrm{o}$ find a form of association that will defend and protect the person and goods of each associate with the full common force, and by means of which each, uniting with all, nevertheless obey only himself and remain as free as before. ${ }^{34}$ Individuality is not simply a good in itself. This could only be

\footnotetext{
${ }^{32}$ Cassirer [1963b], p. 47. This is precisely the sense in which Proudhon understands the concept of Divine as we will see in chapter five.

${ }^{33}$ This is the key argument of Émile but it ought also to be recognised that there is a serious contradiction in his thinking here that is almost universally recognised. No knowledge is unmediated and the tutor is a central figure in Émile's education. No less is this contradiction made evident in the duplicity of Rousseau's arguments that women are not capable of this form of learning and must be taught societies customs instead. See, for example, Parry, [2001].

${ }^{34}$ Rousseau [1997c], pp. 49-50.
} 
the case in the pre-social state of nature. Individuality was acceptable then because it affected no one. In the social state, individuality leads to anarchy and the individualist materialism so eloquently described by Hobbes. Thus Hobbes' civil state is Rousseau's hell because it not only alienates us from our passions, it also forces our individuality into an artificial as opposed to a natural, social union. Thus Rousseau's social contract is central to realising our God-given individuality and once we associate properly, the aggregate (though reducible) General Will would be no less divinely infused and its actions divinely sanctioned. God is thus necessary for moral freedom.

\section{The Civil Religion}

The centrality of the idea of "sentiments of sociability" as a proof of the social contract, and Voltaire and Rousseau's fight against reason, is brought out most clearly in the chapter on the 'Civil Religion' that closes the Social Contract. Rousseau here makes clear that the Lawgiver cannot demonstrate the importance of the sovereign empirically any more than he can demonstrate the existence of God; he can only offer the suggestion of individual sociability that will naturally compel us into union, and the corresponding need for a higher power to "establish 'moral' certainty." It is for this reason that "The lawgiver must invoke the gods in order to persuade the vulgar whom he cannot convince. ${ }^{35}$ In the absence of empirical proof to support the arguments in favour of the social contract, an absence which was to have profound effects on Comte's understanding of the politics of positivism, Rousseau had to appeal to something else: God. As he put it:

There is therefore a purely civil profession of faith the articles of which it is up to the sovereign to fix, not precisely as dogmas of religion but as sentiments of sociability, without which it is impossible to be either a good Citizen or a loyal subject. Without being able to oblige anyone to believe them, the sovereign may banish from the state anyone who does not believe them; it may banish him, not as impious but as unsociable, as incapable of sincerely loving the laws, justice, and, if need be of sacrificing his life to his duty. If anyone, after having publicly acknowledged these same dogmas,

\footnotetext{
${ }^{35}$ Rousseau [1997b], p. 211.
} 
behaves as if he did not believe them, let him be punished with death; he has committed the greatest of crimes, he has lied before the laws. ${ }^{36}$

This functional use of religion illustrates that while Rousseau and others understood that religion reflected something deeply set within our personal psyches, what it was or how this was so was always secondary to how it could be manipulated for political ends. Indeed, the number of times this position has been taken 'as gospel', quite literally by Robespierre it might be added, prompting what we now term ethnic cleansing, beggars belief.

Read in the context of his letter to Voltaire we can see that Rousseau is arguing that laws are both the thing which bind us together and bring us closer to God. Respecting them ought to lead to peace and those who defy them are, by this formulation anti-social/anticivil and thus Godless. It is thus imperative, if the Sovereign is to realise the will of the people - which is also the will of God - that the state be made homogenous in terms of language, law, culture, religion, and so forth. Difference and contestation is proof of the indeterminacy of law and thus of the will of God. Building on his experience of Calvinist Geneva, ${ }^{37}$ he argued that states must have official religions, a unified and civic education system, a unicameral parliament and a single Lawgiver. Only then will the state be able to define itself as a true "Communion of Citizens", assert its independence and through the Lawgivers, secular Calvinist Bishops in this case, assert their sovereign rights here on earth.

The ideal society is our transcendent salvation in this world, it is the institutional complex within which we can realise our harmonious natures and develop into the upright individuals God designed us to be in the fullness of social time. As Peter Gay has shown,

The Social Contract takes up where Rousseau's first two discourses had left off: it is a demonstration that the exchange of natural freedom for civic

\footnotetext{
${ }^{36}$ Rousseau [1997c], p.150.

${ }^{37}$ Mason [1993].
} 
freedom is worth making, for it is this exchange that elevates man into a moral being capable of realising his potentialities. ${ }^{38}$

We can thus re-read the following to indicate a more providential and religious intention:

Anyone who dares to institute a people must feel capable of, so to speak, changing human nature; of transforming each individual who by himself is a perfect and solitary whole into part of a larger whole from which that individual would as it were receive his life and his being [...] The more these natural forces are dead and destroyed, the greater and more lasting are the acquired ones, and the more solid and lasting is the institution [of popular sovereignty]..$^{39}$

Thus religion, or rather the assumption of God, is central to legitimising the alienation of our political capacities in our [providential] interests. Rousseau's aim was to show how the will of the people is the will of god - vox populi, vox dei - and his extremely illiberal attitudes towards human difference are explicable by his experience of Genevan Calvinism.

Of course this has huge implications for how Rousseau would have people understand and act in international politics. Crucially, this way of formulating the social contract, along the lines of social homogeneity, distinct political hierarchies and religious or cultural exceptionalism, leads instantly (if mainly conceptually) to international or interstate anarchy and the corresponding need to pacify it much in the same way as the presocial anarchy needed pacifying - by the development of a general will and civil code.

The individuality of the pre-social ideal becomes the bane of civilised life when pushed outside society into the international. This might be considered to be something of a contradiction had Rousseau not argued that international anarchy was also a result of civilization and thus something we must and will transcend by instituting a perpetual

\footnotetext{
${ }^{38}$ Gay [1969], p. 549.

${ }^{39}$ Rousseau [1997c], p. 69.
} 
peace between republican states. ${ }^{40}$ For Rousseau, the nascent international society must become harmonious by constituting itself as a universal federation of civilised states. The essay "The State of $\mathrm{War}^{41}$ is clear, this social state of all against all that Hobbes expounded is a rationalist fantasy and Rousseau is explicit that Hobbes was wrong to stipulate it as such and believed its necessity in international politics was no less fanciful. All that was required was for states to be reformulated along the lines he suggested and then brought into a universal federation and all would be well - but Rousseau had no clear ideas as to how this might happen. As Tuck has argued, Rousseau could provide no solution to this normative problem he had ironically inherited from Hobbes. ${ }^{42}$ How can civil society both be sovereign and respect some sort of federal jurisdiction? To others this conundrum was less of a problem and the solution was to argue for universal republics through internal and external imperialism. One of the clearest examples of this move can be found in Kant.

\section{The Metaphysics of Mind, Morality and History:}

\section{Kant's Critique of Rousseau}

Kant's work has also inspired innumerable analyses and interpretations, both within IR, political theory and more obviously within philosophy. It is impossible to summarise them here and I do not claim to be providing an original reading of Kant either. What I want to show here is how and why Kant rethinks Rousseau, whom he called the "Newton of the Moral Realm”, and what he does with the results of his re-reading. ${ }^{43}$ My aim will be to show how Kant essentially came to similar conclusions as Rousseau, but despite setting out from entirely different starting points. I will also show that God was vital to Kant's thinking too, particularly in relation to his philosophy of history. To understand Kant's system here we have to start with its foundational assumptions and build up to his philosophy of history. The detail is central to understanding Kant's critique of Rousseau,

\footnotetext{
${ }^{40}$ Rousseau [2002].

${ }^{41}$ Rousseau [1997a].

42 Tuck [2001], p. 207.

43 The analysis leans heavily on Cassirer [1963a, 1963b].
} 
Comte's critique of both and how Proudhon then again reframes the mission of philosophy in De la Justice.

\section{Phenomena and Noumena}

Kant's entire philosophy rests on a basic ontological assumption about the nature of thought and the material world. Writing in the wake of the Newtonian revolution and its mechanical world view, Kant sought to carve out separate domains for thought and material reality to ensure that the one was not reduced to the other. He does this by dividing the world between the phenomenal world of time and causation that is a possible object of sensual experience, governed by the mechanical laws uncovered by Newton; and the noumenal realm knowable only as ideas and outside the realm of sensory experience and science. This is the realm of metaphysics, and it is beyond natural science because, for Kant at least, it is the cognitive precondition of it.

Crucially Kant argues that we cannot know the empirical realm of phenomena in and of itself, unmediated by the senses and the faculty of reason which gives it rational, cognitive shape. Kant was well aware that science and philosophy had failed in its attempt to know the 'thing in itself', and this failure promoted the primacy of the epistemological question over the ontological, or on what basis can we justify our (now more limited) knowledge claims? Kant answers by saying that since perceptions and appearances are mediated through the noumenal realm of the mind, if we want to know what a thing 'is' we need to know how our minds make sense of the empirical domain. What this ultimately translated into was a slide towards philosophical idealism, wherein our minds actually make objects real. ${ }^{44}$

Kant's transcendental idealism balanced delicately between empirical realism and ontological idealism. What he sought was to make the phenomenal realm objectively and universally intelligible to reason, by bringing it and the noumenal realm into harmony. Much as the discovery of the laws of gravity had huge implications for our understanding of the material world, Kant believed that if we could discover all the laws of morality we

\footnotetext{
${ }^{44}$ Kant [1993], pp. 380-381.
} 
would be able to live in harmony with them. The ensuing science of the mind sought thus to unite "the capacities of the knower with the nature of the known". ${ }^{45}$ But making value judgements were not the same as making scientific judgements. The latter has nothing to do with morality and our minds because our minds are not reducible to material mechanisms. Körner has argued that for Kant,

Judging and perceiving are irreducibly different. In this he is opposed both to his rationalist predecessors, for whom perceiving was a kind of low-grade judging, and to his empiricist teachers [e.g., Hume], who were inclined to assimilate judging to perceiving. Kant expresses the sharp distinction between judging and perceiving as between two distinct faculties of the mind: understanding and sense. ${ }^{46}$

The challenge Kant set himself was thus to show how the mind, through use of data supplied by the senses could come to objective (value) judgements about the world and how to act in it. Crucially, however, there judgements were to be worked out independently of the empirical world, through a process of objective and deductive reflection. This is the polar opposite of Rousseau's search for our passionate animus, but it echoes the oracle of Delphi by starting from the same position of "Know Thyself".

\section{The Categories of Pure Reason}

The noumenal realm is composed, broadly speaking, of twelve "categories” and a number of "concepts" and corresponding "ideas" which, combined, can make objective sense of phenomenal things. These categories, ideas and concepts can do this because they are innate, universal and transcendental and do not operate according to the laws of the empirical world because, again, Kant argues that they are the precondition of them. ${ }^{47}$ Both concepts and categories combine to create a "manifold" of a priori ideas. They are a priori because they are not objects of possible experience, they precede cognition and

\footnotetext{
${ }^{45}$ Ibid., pp. 23-24.

${ }^{46}$ Körner [1955], p. 30

${ }^{47}$ The details of their interrelation are the subject of the Critique of Pure Reason and it is impossible to summarise or do justice to this here.
} 
exist independently of the phenomenal realm. We will see later how this concept of the $a$ priori performs an important theological function, but here it is important to note that for Kant, “an 'objective deduction' of the categories is required: an argument that will show that the world, and not just our experience of the world, is in conformity with the a priori principles of the understanding." 48 If this demonstration can be made, if the world and our ideas of it can be brought into transcendental harmony, this would constitute the realisation of reason - Enlightenment. Kant believes he can show that progress from intuition to reason, from sense to the full rational exercise of our faculties unmediated by instinct, is not only possible, but inevitable. But crucially, this change in forms of cognition is not in time but in noumenal capacity.

This is where Kant's famous dictum of the relationship between intuitions and sense is derived: "Understanding cannot intuit and the sensible faculty cannot think. In no other way than from a united operation of both, can knowledge arise." ${ }^{49}$ Kant refused to make the categories (the part of the brain central to understanding and objectivity) phenomenal. They were beyond science, existing in a timeless, space-less and substance-less ether. The simple reason why Kant makes this case is that for eighteenth-century thought the phenomenal, Newtonian system suggested that the material realm was one of determinism and of law-governed causation. Free will, the central feature of the exercise of reason, could not exist in this realm since it would be determined by the material laws of cause and effect. Our minds must be the realm of free will, devoid of the laws of causality, if philosophy or metaphysics were to retain their autonomy within the sciences, and if we were to account for the irreducibility of our ideas and thus our individuality.

There is a second reason for this distinction. Kant was also trying to carve out an important realm of individual responsibility for human action. This realm of responsibility would become one of duty and thus of morality. Take the following as a key example to which we will return below:

\footnotetext{
${ }^{48}$ Scruton [1982], p. 28.

${ }^{49}$ Kant [1993], pp. 69-70.
} 
Let us take a voluntary action - for example, a malicious lie [...] We at first proceed to examine the empirical character of the offence, and for this purpose we endeavour to penetrate to the sources of that character, such as a defective education, bad company, a shameless and wicked disposition, frivolity, and want of reflection - not forgetting also the occasioning causes which prevailed at the moment of the transgression [...] Now, although we believe the action to have been determined by all these circumstances, we do not the less blame the offender [...] Our blame of the offender is grounded upon a law of reason, which requires us to regard this faculty as a cause, which could have and ought to have otherwise determined the behaviour of the offender, independently of all empirical conditions [...] It follows that we regard reason, irrespective of the empirical conditions of the act, as completely free, and therefore, as in the present case, culpable. ${ }^{50}$

Again, our ideas let us down because we have not understood for ourselves that the right thing to do was not to tell the lie. Reason therefore exists beyond, and untouched by, the phenomenal world. Kant wants to argue that all humans, irrespective of time and place have similar capacities to reason but employ those capacities differently and are at different stages of intellectual development. But in saying that place and time are unimportant Kant was bucking a deep trend in continental thought - particularly the work of Montesquieu and Rousseau, Locke and his tabula rasa theory of mind and Humean sensualism, each of which suggested that society and the world out there was the chief determinant of our ideas. Kant argued that the empirical world has nothing to do with the matter.

But Kant was also seeking to do something quite different. He was seeking to actively scrub the influence of the passions, the central principle of Rousseau's politics (and the animating force of the irrational revolutionaries) from politics. Ought could not be conditioned by is; quite the opposite. Once the nature of morality has been rationally divined, is, or the real world must to be brought into harmony with this ought. The task remained of deciding what the rational ought was. This was precisely Turgot's position

${ }^{50}$ Ibid., pp. 387-388. 
and problem, articulated at almost exactly the same time, that I mentioned in the previous chapter. Of course, Kant also wants much the same as Rousseau in this respect, but he also wanted to grant the natural sciences their empirical independence and retain the idiosyncrasy of the cognitive sciences. And vitally, he wants to get rid of passionate, romantic rebellion.

\section{God, Ideas and the Antinomies of Pure Reason}

Returning to the metaphysics, if the categories are innate and unconditioned by any of the laws of causality, how do we develop new ideas? Kant argues that the categories of pure reason have their own natural, innate checks, and that these reside in the antinomies between the inherent dualism of the categories. Kant's theory of the antinomies was to have huge consequences for continental metaphysics. It gave rise to Hegel's reformulation of the dialectic, Marx's reworking of Hegel, and Proudhon's own version of Kantian antimonies that was so central to his theory of conflict and change. But the productive antagonism of the antinomies is also the root of Kant's philosophy of history. It explains his approach to war, change and progress, and finally, the antinomies bring us closer to God.

Kant argued that the antinomies of pure reason arise mainly from the vanities of speculative metaphysics - the trademark discipline of those who preceded Kant. The three main subjects were cosmology, theology and psychology. Focusing on rational cosmology for the sake of brevity here, Kant saw four antinomies arising from it: beginning and end (time); parts and the whole (substance); determined and undetermined (causation); existence vs. the non-existence of God (theology). All thinking about the subjects dealt with by the categories inevitably comes up against these absolutes which we cannot think beyond. The poles of the antinomies have neither meaning without their opposite nor any function except in tandem, nor, crucially, can they be reconciled or transcended: there is no proof of the existence or absence of God; no cause is final or the first, and so on. The antinomies set the rational limits of human thought beyond which it is futile to extend. But as Scruton shows, "these antinomies are not to be lightly 
dismissed as errors no sooner perceived than forgone. The assumption of totality which generates them is both the cause and effect of all that is most serious in science."51

What Kant argues here is that while the antinomies operate as a check on pure reason, by recognising these limits the antagonism between the antinomies compels (but does not cause) the reason of the savant to extend to its limits and then reflect back upon itself, which induces it to be critical. This fantastical realm at the limits of pure reason is thus a precondition of the possibility of thought as such (and thus of everything else too). The transcendent idea of unity towards which reason aspires can never be achieved, but the struggle for it produces ideas. Our minds simply cannot perceive this realm thought they struggle perpetually to do so. This struggle to perceive using sense data and the deduction of the categories is the origin of thought and the discoveries of reason and science as they make sense of sense experience. This incomprehensible realm is also God and in struggling to know Him, we therefore come to know ourselves.

It was Voltaire who argued that if God did not exist it would be necessary to invent him and Kant concurred. He concurred for political reasons, arguing that "the church fulfils a genuine political necessity, for it enables the people to regard themselves as subjects of an invisible power to which they must pay homage and which may often come into very unequal conflict with the civil power." ${ }^{\text {,2 }}$ But this conflict is one premised on the freedom of religious belief which is also a function of intellectual freedom. This is because antinomic speculation is part of the rational process that helps us think and brings us closer to the Divine and our minds closer to a transcendental unity with nature.

Thus, perhaps the most important formal "Idea” for Kant is the "Idea” of God. God cannot be posited or understood empirically for that would be to corrupt his perfection. God, reality or perfection can only be posited as ideas without empirical form (but with their own opposites), and ideas absolutely necessary to the progress of knowledge, perceptions, and science. This argument performs a double function, for it also supports a further denial of the possibility of a real world beyond our judgemental capacities and in

\footnotetext{
${ }^{51}$ Scruton [1982], p. 50.

${ }^{52}$ But if the religious sentiment threatens the security of the state, Kant argues that the state can and should repress religious thought with impunity. Kant [1991c], pp. 150-151.
} 
cruder readings leads to pure philosophical idealism and solipsism. But as the categories are a precondition of thought because they are presupposed in it, Kant makes God a precondition of thought and thus the possibility of reality in general, and places Him outside of everything as a precondition of everything that cannot be touched. The chapters that comprise the Transcendental Dialectic verge on pantheism in their expression of the unity of nature, but they are quite clear also that over and above all of this there is a "Supreme Being, who is the free and intelligent author of all things." 53 But this is just an idea since we cannot rationally conceive of God. Indeed, "The idea of a Supreme Being” he argues, "is in many respects a highly useful idea; but for the very reason that it is an idea, it is incapable of enlarging our knowledge with regard to the existence of things." 54 Switching to morality, Kant argued that "moral laws not [only] presuppose the existence of a Supreme Being, but also, as themselves absolutely necessary in different relation, demand or postulate it - although only from the practical point of view."55 As with Rousseau, Kant believes God resides in all laws - phenomenal or noumenal.

Kantian "Ideas" thus have a formal role in this system. He argues that "[i]f we review our knowledge in its entire extent, we shall find that the peculiar business of reason is to arrange it into a system, that is to say, to give it connection according to a principle."56 This is what ideas do: they provide an idea of unity that is regulative of our fanciful explanations of infinity and gives concrete shape, derived from the exercise of critical reason, to the basis of the principles of practical reason. Ideas help us act in a world that presents us with absolutely no empirical indicators of what is right or wrong. God is not just one such idea among many, but is the most important for cognitive, moral and scientific reasons.

\footnotetext{
${ }^{53}$ Kant [1993], p. 428.

${ }^{54}$ Ibid., p. 412.

${ }^{55}$ Ibid., p. 429.

${ }^{56}$ Kant [1993], p. 435.
} 


\section{The Categorical Imperative and the Retreat from the Passions}

It should be clear by now that for Kant the phenomenal world is not the place to look for foundations to our thought and judgement. Kant was unequivocal; "man” he argued "should not partake of any other happiness or perfection than that which he has produced for himself without instinct and by his own reason". ${ }^{57}$ In fact, our instinct or "asocial qualities" are "far from admirable". ${ }^{58}$ We cannot allow our more base inclinations to hamper our thinking, he argues, and here he refers to women who, by his formulation are incapable of rational action and are too passionate. ${ }^{59}$ In place of the Rousseauean paradigm of the passionate proximity to God was placed a conception of morality that was premised on rationality. Rather than feel our way to God, Kant would have us think our way to Him. In the "Idea of a Universal History", Kant argues, contra Rousseau that the passions are "pathological” 60 . Moreover, since the phenomenal realm cannot furnish us with moral judgements, we ought to focus on the workings of reason and the logical coherence of our moral maxims. As with Rousseau, this attempt to regain our moral autonomy from the dictates of earthly religious dogma also allows the natural workings of our reason to take us closer to God. As Kant argues in the Groundwork to the Metaphysics of Morals:

Hence pure philosophy (that is, metaphysics) must come first, and without it there can be no moral philosophy at all. Indeed a philosophy which mixes up these pure principles with empirical ones does not deserve the name of philosophy (since philosophy is distinguished from ordinary rational knowledge precisely because it sets forth in a separate science what the latter apprehends only as confused with other things). Still less does it deserve the

\footnotetext{
${ }^{57}$ Kant [1991a], p. 43.

${ }^{58}$ Ibid., p. 45.

${ }^{59}$ See Kant [1853]. The first part of this work relates to 'Private Right' wherein Kant makes a fundamental distinction between men and women. Contrary to the universalism of his system, women simply cannot reason as men do and this justifies half the world's populations' subservience and their exclusion from public life. For an excellent discussion of this aspect of Kant's thought see Mendus [1992]. I regret I cannot take this discussion further but feminism provides the best critique of all the thinkers presented here including Proudhon.

${ }^{60}$ Kant [1991], p. 45.
} 
name of moral philosophy since by this very confusion it undermines even the purity of morals themselves and acts against its own proper purpose. ${ }^{61}$

The idea is that only actions derived from maxims of duty that can be universalised and used to govern action can be said to be moral. Once these maxims of moral duty have been discovered society can be re-organised accordingly. In fact, “[t]here is only a single categorical imperative and it is this: 'Act only on that maxim through which you can at the same time will that it should become a universal law." ${ }^{62}$ Moral action is thus not based on rights (selfish entitlements for Kant), but on moral duties that generate social harmony because we act not in our own interest, but in society's.

For Kant man must be considered an end in himself, an individual. The problem with this formulation resides in deciding whether maxims of moral behaviour can ever be universalised, who ought to decide which are the most important, and finally what to do with people who ignore them? Take the duty to always tell the truth for example. If we all lied, chaos would reign. Of this there is no doubt. But if we all told the truthuniversalising the duty not to lie - at all times, can we guarantee consequences that are always good? For Kant this would be finishing where we ought to be starting. The reason this system is de-ontological or absolute in its ethical content, is that the consequences have no bearing whatsoever on the ethical content of the maxim. Indeed, even if one were to lie to protect the life of one's innocent friend, one would be breaking the categorical imperative. But it is clear that life is not like this, so what of evil? How do we account for those who ignore the maxims and what should we do about them?

\section{Theodicy, Morality and the State in Kant's Philosophy of History}

This section is of necessity too brief to do justice to the sheer depth and scale of Kant's philosophy of history. My task is also circumscribed by the need to show how the above philosophical and moral systems work themselves out over time. Following Cassirer and Despland, I will argue that there are two aspects to Kant's philosophy of history and that

\footnotetext{
${ }^{61}$ Kant [1964], p. 58.

${ }^{62}$ Ibid., 88.
} 
they both bear strongly on any interpretation of Comte and Proudhon. The first is Kant's use of the philosophy of history to argue for an 'Idea' of theistic providentialism, which brings him closer still to Rousseau. The second aspect of Kant's philosophy of history is the centrality of war to providence and progressive change.

The object of devising an "Idea" of a "Universal History", with a "Cosmopolitan Purpose" involves ascertaining the "integrated, prearranged plan" of the universe so as to give it to others as a rational blueprint for moral action in the here-and-now in the hope that this may eventually lead us to the 'Kingdom of Ends'. In other words Kant believes that his Idea can not only generate a set of ideas that would be in harmony with the nature of the real world, but that if these ideas were followed by all "rational Cosmopolitans" we would come to live in transcendental harmony. ${ }^{63}$ Again, Enlightenment hubris cannot be overlooked here.

Kant is clearly ambivalent as to whether any such Cosmopolitans have ever, or will ever exist but this is unimportant for what is vital is that we ought to live as though we were such individuals. We ought to be guided by the image of the harmonious society such rational cosmopolitans would ideally live in. The problem, as Kant was hearing about on a daily basis no doubt, is that we are too easily swayed by our passions, by base interests and instincts that divert us from the rational and the ideal.

The first of the nine propositions of the 'Idea' is that we ought to believe that " $[a] l l$ the natural capacities of a creature are destined sooner or later to be developed completely in conformity with their end." This is the "teleological theory of nature", which if abandoned would imply that "we are faced not with a law-governed nature, but with an aimless, random process, and the dismal reign of chance replaces the guiding principle of reason." ${ }^{\prime 64}$ The aim of science is thus to discover human history’s transcendental purpose, a task that is far more complex to achieve than it would be, say, "with bees or beavers". 65 Bees and beavers, it is implied, have already come to exist in harmony with their natures and surroundings and do so automatically. If nature is not to be seen to be "indulging in

\footnotetext{
${ }^{63}$ Kant [1991a], p. 41.

${ }^{64}$ Ibid. (Emphasis in original).

${ }^{65}$ Ibid., p. 42.
} 
childish play in the case of man alone" ${ }^{66}$ humans must also be in a process of moral and rational evolution, the end-point of which will be the equivalent of the beaver's "automatic" ${ }^{67}$ social regulation. This idea is repeated in Perpetual Peace where Kant observes that reindeer and camels "seem[...] as if [they] had been created"68 for their locations. What this assumes is that Kant believed we had reached our end as organisms but needed to adapt our thoughts to produce better social outcomes. It also shows how deeply creationist he was.

The philosophy of history this develops into is designed to show that life cannot be "purposive in its parts but purposeless as a whole."69 Kant is here arguing, much as had Rousseau with Voltaire, that there is reason to believe in a Divine providence in human life despite prima facie evidence to the contrary. The key evidence was war and revolution and it is here that we see the turn towards international relations. Indeed, as Despland's work shows, and as I will support here and in the chapters to follow, "in the eighteenth century the philosophy of history was a burning religious question". ${ }^{70}$ It is through his philosophy of history that Kant was able to link inter-state war, a quintessentially phenomenal process, to reason and providence and solve Rousseau's international problematique. But as Cassirer has argued, Kant's solution demanded rethinking Rousseau almost completely.

Kant's solution again begins with individual rational cognition. What we know is that the key motor which produces thought and the discoveries of science in Kant's thought are the antinomies of pure reason. This actual (if not real) antagonism between the antinomic poles of the categories has an 'ideal' corollary in his philosophy of history. "By antagonism” he writes in tones which clearly echo Rousseau's formulation, "I mean in this context the unsocial sociability of men, that is, their tendency to come together in society, coupled, however, with a continual resistance which constantly threatens to break this society up." ${ }^{71}$ This is also almost exactly how Proudhon came to formulate it as I will

\footnotetext{
${ }^{66}$ Ibid., p. 43.

${ }^{67}$ Ibid., p. 48.

${ }^{68}$ Kant [1991b] p. 110.

${ }^{69}$ Kant [1991a], p. 48.

${ }^{70}$ Despland [1973], p. 6.

${ }^{71}$ Kant [1991a], p. 44.
} 
show in chapter five. Kant also argued that our instinctive, passionate animus is what brings us together into society and also constantly works to break society down - which justifies expunging it from politics. Bringing reason into our dealings with one another would, as Rousseau argued in the Social Contract, substitute instinct for justice, or as Kant put it: a "pathologically enforced social union is transformed into a moral whole". ${ }^{72}$

Man wishes concord, but nature, knowing better what is good for his species, wishes discord [... which] would seem to indicate the hand of a wise creator - not, as it might seem, the hand of a malicious spirit who had meddled in the creator's glorious work or spoiled it out of envy. ${ }^{73}$

Kant also laments the passing of an "Arcadian, pastoral existence of perfect concord, self sufficiency and mutual love"74 but foresees something far better for man in the future. The idea of God plays a hugely important part in Kant's thought here for what he is trying to show is that providence is on our side. In 'Perpetual Peace' Kant argues that "War itself $[\ldots]$ does not require any particular kind of motivation, for it seems to be ingrained in human nature, and even to be regarded as something noble to which man is inspired by his love of honour, without selfish motives." ${ }^{75}$ War is thus Providential.

In the short term however, man "requires a master to break his self-will and force him to obey a universally valid will under which everyone can be free [...] Yet the highest authority has to be just in itself and yet also a man [...] and a perfect solution is impossible. Nothing straight can be constructed from such warped wood as that which man is made of."76 Thus, in short, the problem of finding the perfectly just civil constitution is one of Biblical proportions and "is both the most difficult and the last to be solved by the human race", ${ }^{77}$

\footnotetext{
${ }^{72}$ Ibid., p. 45.

${ }^{73}$ Ibid.

${ }^{74}$ Ibid.

${ }^{75}$ Kant [1991b], p. 111.

${ }^{76}$ Kant [1991a], p. 46.

${ }^{77}$ Ibid., p. 46.
} 
This task is compounded by the average man's level of intelligence and his natural inquisitiveness. In the Metaphysics of Morals Kant argues that, much as the nature of God is beyond human reason to comprehend, the origin of the secular power ought to be kept beyond analysis. Kant argues that,

The origin of the supreme power [like the Supreme Being before it], for all practical purposes, is not discoverable by the people who are subject to it. In other words, the subject ought not to indulge in speculations about its origins with a view to acting upon them, as if its right to be obeyed were open to doubt (jus controversum). ${ }^{78}$

Kant is clear that in order to ensure social harmony there must be a legitimate power that can govern absolutely and this sovereign must be allowed to go to war to push progress on to other states. Echoing Rousseau again, Kant argues that to disobey the supreme power would warrant being "punished, eliminated or banished as an outlaw."79 The supreme power is sanctified by the 'Idea' that “'all authority comes from God' which is not a historical derivation of the civil constitution, but an idea expressed as a practical principle of reason, requiring men to obey [...] irrespective of origins. ${ }^{„ 80}$ He is quite clear that representatives therefore ought to look after subjects or citizen's rights "on their behalf", that this representation is held in perpetuity. Since the sovereign "allows himself to be represented” by the representatives, sovereignty itself becomes popularised without any popular participation. But perhaps most importantly, the people need representatives "for [without them] they might then destroy all the new institutions again by their absolute and arbitrary will." ${ }^{\text {}}$ Place this within the absolute duty to obey the sovereign and you have a despotism that surpasses even Rousseau's, and an ideology which sanctifies imperialism in the name of spreading republicanism. ${ }^{82}$ This was neither uncommon nor widely criticised. ${ }^{83}$

\footnotetext{
${ }^{78}$ Kant [1991c], p. 143.

${ }^{79}$ Ibid.

${ }^{80}$ Ibid.

${ }^{81}$ Ibid., p. 163.

${ }^{82}$ Nicholson [1976].

${ }^{83}$ See Wolff [1988] for one of the few contemporary Kantian critiques of Kant.
} 
This form of republicanism, Kant argued, is the only system which allows "freedom under external laws", and best approximates the future's "perfectly just civil constitution". ${ }^{84}$ Extending it is actually more important than defending it. This is his solution to Rousseau's problem. He argued that, "[t]he problem of a perfect civil constitution is subordinate to the problem of a law-governed external relationship with other states, and cannot be solved unless the latter is also solved." ${ }^{85}$ The only way to bring this about is to bring the republican model to state's relations with other states which could only be expected if other states were also republican. Kant continues that ultimately every state should rationally accede to,

entering a federation of peoples in which every state, even the smallest, could expect to derive its security and rights not from its own power or its own legal judgement, but solely from this great federation (Foedus Amphictyonum), from a united power and the law-governed decisions of a united will. However wild and fanciful this idea may appear - and it has been ridiculed as such when put forward by the Abbé St Pierre and Rousseau (perhaps because they thought that its realisation was so imminent) - it is nonetheless the inevitable outcome of the distress in which men involve one another. ${ }^{86}$

Kant's metaphysics are imperialistic to the core, and their symmetry is astounding. All the machinations of international politics "compel our species to discover a law of equilibrium to regulate the essentially healthy hostility which prevails among states and is produced by their freedom." ${ }^{\text {87 }}$ As Kant argued in the Metaphysics of Morals:

there are plausible enough arguments for the use of violence [to expand territory and rule] on the grounds that it is in the best interests of the world as a whole. For on the one hand it may bring culture to uncivilised peoples [...] and on the other, it may help us to purge our country of depraved characters,

\footnotetext{
${ }^{84}$ Kant [1991a], p. 45, 46.

${ }^{85}$ Ibid., p. 47.

${ }^{86}$ Ibid., pp. 47-48.

${ }^{87}$ Ibid., p. 49 (emphasis added).
} 
at the same time affording the hope that they or their offspring will become reformed in another continent (as in New Holland). ${ }^{88}$

This was a clear echo of centuries of European foreign policies and was to be echoed for centuries to come. But with a final flourish the ninth and final proposition of the "Idea" is in this regard probably the most striking in terms of our understanding of Proudhon, Hegel, Comte and Marx and others who were to follow. Kant argues that " $A$ philosophical attempt to work out a universal history of the world in accordance with a plan of nature aimed at a perfect civil union of mankind, must be regarded as possible and even as capable of furthering the purpose of nature itself." ${ }^{\prime 9}$ And here we see the final purpose of 'Ideas': they are systems of thought that correspond with the architectonic construction of the mind and its system of logic and reason. When harmonised with the nature of the phenomenal realm, by forcing the real to correspond with our ideal conceptions of it, harmony will come to pass. In sum then, for Kant,

\begin{abstract}
All wars are accordingly so many attempts (not indeed by the intention of men, but by the intention of nature) to bring about new relations between states, and, by the destruction or at least the dismemberment of old entities, to create new ones. But these new bodies, either of themselves or alongside one another, will in turn be unable to survive, and will thus necessarily undergo further revolutions of a similar sort, till finally, partly by common external agreement and legislation, a state of affairs is created which, like a civil commonwealth, can maintain itself automatically. ${ }^{90}$
\end{abstract}

This appeal to the automatic presumably advocates turning us all into "bees or beavers". Tuck has argued that Kant's later writings ought to be read in the context of "Europe of the year III” in which the French had come up against the Prussians and Austrians and had lost. Nevertheless Kant's ideas had infused the states of the Rhineland with providential theories of republican federation. Even "Sieyès's, [...who] in 1795 [...]

\footnotetext{
${ }^{88}$ Kant [1991c], pp. 172-173. This makes Kant something of the 'sorry comforter' that he criticised Grotius, Pufendorf and Vattel for being in Perpetual Peace. See Kant [1991b], p. 103.

${ }^{89}$ Ibid., p. 51.

${ }^{90}$ Kant [1991a], p. 48.
} 
suggested a new federation in Germany, 'constituted more soundly and vigorously than that erected by chance in the Gothic ages, and guaranteed by the Republic.",91 Republicanism and imperialism were two sides of the same coin. It was the terms on which they became justified that soon began to change.

\section{Comte’s Positivist Sociology and the Religion of Humanity}

Both Rousseau and Kant believed in divine providence. This has been my argument thus far. Where Rousseau failed to justify or think through the limitations of his argument visà-vis international anarchy, Kant went further and simply justified imperialism by reference to God's plan on earth. Despite being partial, this type of synopsis has been hugely influential. Indeed, writing about Comte and other Saint-Simonian impressions of Kant's 'Idea of a Universal History', Manuel has argued that Kant's "good out of evil” thesis provided them with a philosophy that was far more "subtle" than those current at the time ${ }^{92}$, but "endowed [their own ideas] with an easy optimism which the Philosopher of Königsberg never expressed." ${ }^{\text {,3 }}$ What I also want to draw attention to, but which Manuel largely overlooks, is the sheer depth of religious expression in Kant's work, the echoes of it in the pantheism of the Saint-Simonians, and their mutual veneration of Newton.

In this third section I want to answer two questions and by so doing provide another slice of the intellectual context in which Proudhon worked in fashioning his own ideas. First, what did Comte mean when he noted (immodestly and rather nonchalantly) that the only worth he could find in his own work, after reading Kant's philosophy of history and fragments of the Critique, was to have come to similar conclusions without having read Kant himself? Secondly, what did Comte mean when he said he wanted to make his own theory of the three states even more deterministic as a result of reading Kant and what were the implications of this move?

\footnotetext{
91 Tuck [2001], p. 224.

92 Manuel [1965], p. 169.

93 Ibid.
} 
I will show that the similarities are indeed striking and that Comte's immodesty is not misplaced - his well-known pedantry being our first guide here. The key reasons for this proximity lie in his reading of the Catholic theocrats de Bonald, de Maistre and Bossuet. But I will show that it is also possible to understand why he would make his future work even more deterministic in two complementary ways. First, the prevalence of teleological arguments in Kant's work, and Kant's importance in German philosophy might have induced Comte to simply jump on the 'determinist bandwagon'. However, Comte might also have been convinced of the correctness of his deterministic theory of human evolution because he denies the noumenal or transcendental content of the mind. As Kant argued, if reason were phenomenal "the causality of reason would [then] be subservient to the natural law of appearances [...] it would consequently cease to be freedom and become a part of nature." 94 I will show that this is exactly what Comte, following Fourier, Montesquieu, Rousseau and others, argued, and in so doing utterly erased the individual in the interests of his organic society.

Here I will focus on what Comte called his "Opuscule Fondamental" The Plan of a Scientific Work Necessary for the Reorganisation of Society. I expand the analysis by reference to the System of Positive Polity. This is a conscious elaboration of the former text that takes into account his reading of Kant in particular, and has the evolution of French politics in the aftermath of the French Revolutionary wars as its normative and political backdrop. These works sought explicitly to contribute to the "efforts of governments to re-establish order in Europe” after the cataclysmic twenty years of revolutionary wars, the failure of the restoration, the failed 1848 revolution and what Comte saw as the promises of the dictatorship of Napoleon III. ${ }^{95}$ Comte's oeuvre is almost existential in its fear of the collapse of society, claiming that the future of mankind depends on the resolution of the "moral and political anarchy which seems to threaten it [civilization] with imminent and inevitable dissolution."96

The section is divided into three parts. First, I will discuss Comte's intellectual debt to the Catholic theocrats and how this influenced his thinking about the nature of critical and

\footnotetext{
${ }^{94}$ Kant [1993], p. 386.

${ }^{95}$ Comte [1998a], pp. 48-49.

${ }^{96}$ Ibid., p. 49.
} 
organic theory. This will provide a backdrop for understanding his critique of Rousseau and Kant that will follow in the second section. I then discuss Comte's philosophy of history and how it relates to his key contribution to French social theory: the law of the three states. I will show how this translates into a theory of social order, and in the final section show how war is vital to the evolution of the perfect universal social order - with France at its centre and Paris as its hub.

\section{Comte and the Catholic Theocrats}

Joseph de Maistre bequeathed, first to Saint-Simon and then through him to Comte, the idea that any stable social order needs a systematic doctrine that can be enforced where it is not accepted as morally true. Writing during the Restoration, de Maistre believed that Catholicism, Divine Right to Rule and the institution of the Aristocracy were the prerequisites of social order and their absence spelled dissolution rather than revolution. De Maistre ideas rang true to many for they illustrated exactly what the previous order had rested upon and how their absence had spelt the collapse of society into war. De Bonald's influence derived from his argument that society needed to be conceived of as an organic whole. He argued that what held society together was its ideas and doctrines, and this idea gave Comte, again via Saint-Simon, the second element of his conception of the "Supreme Being”, or the "Collective Organism", both euphemisms for society. ${ }^{97}$ This conception of the two things which gave order to society - divine institutions and ideas came under the title of "Social Statics" in Comte's sociology.

As Pickering has argued (above), Kant replaced Condorcet in Comte's ideas about history. Manuel has shown that of the influence of the former the following was crucial. Essentially, Condorcet believed cannons and gunpowder "poured forth a host of salutary results” including forcing a distance between the combatants and providing defence from the threat of the Barbarians or less civilised people. ${ }^{98}$

\footnotetext{
${ }^{97}$ See Jones [1998], pp. xiii, xvi.

${ }^{98}$ Manuel [1965], p. 73.
} 
This materialist providentialism was of profound influence in shaping Comte's analysis of the transition from the medieval to the modern age, as I will show below. However, the role of ideas is also central for Comte. Following Bousset he argued for a type of history that would provide for "the rational co-ordination of the fundamental sequence of the various events of human history according to a single design, at once more real and more extensive than that conceived by Bossuet."99 The similarities between the thought of Kant and Comte are striking and lend plausibility to the argument that Comte had indeed come to the same conclusions. Of course, despite the theological origins of these arguments, there were also deep differences between the two.

\section{Critical and Organic Doctrines}

Comte also uses the Catholic theocrats to help him forge a distinction between critical and organic social doctrines. The "critical doctrine" of the revolutionaries was central to the malaise of the revolution. It arose from the anarchic consequences of individuals exercising their reason unchecked by anything else. Comte's solution was to search for, find and institute, one universal "organic doctrine" based on coordinating principles and ideas which Comte believed himself to have discovered. ${ }^{100}$ While there is some acknowledgement that the revolutionaries play an important part in generating the future social order, the origin of the revolution was "the necessary consequence of the course of civilization" and had very little to do with them. "Far from being the effect of the [present] crisis" the "fall of the feudal and theological system" was the cause of it and thus no one person or group could have instigated it. ${ }^{101}$

Writing during the Restoration period, Comte argues that there are two major contradictions at the heart of modern civilization. The first is the tension between the monarchy and the people, the former attempting to restore itself while the latter seeks to destroy it. Paradoxically, the actions of the monarchy merely exacerbate the tension and

\footnotetext{
${ }^{99}$ Cited in Aron [1968], p. 94. (emphasis added).

${ }^{100}$ Rousseau had equated the Organic vision of society with a vision of the state as a body. States, he believed, could not be expected to hold together by ideas alone because "the least accident can disjoin anything.” Force was thus necessary to “make men free”. Rousseau [1997a], p. 170. cf., Rousseau [1997d], p 6.

${ }^{101}$ Comte [1998a], p. 51.
} 
speed up its decline. The second contradiction is that between monarchy and the sciences and industry - or between science and tradition. Here, monarchy, by propping up the very institutions which are demonstrating its superfluity to modern society, are "accelerating the system that is to replace it." ${ }^{102}$ Comte sees "[i]ntellects [everywhere] which think they are struggling most against the course of civilization unknowingly obey its irresistible influence, and themselves contribute to it." ${ }^{103}$ It is in this way that he allows himself to break with the Theocrats but there is a clear indication that the legacy of the theocrats would turn into a comprehensive structural approach to history that saw no role for the individual.

\section{On Rousseau and Kant}

Despite his critique of Rousseau and the effects of his doctrine on French politics, Comte was full of admiration for the success, rather than the content, of Rousseau's ideas. $\mathrm{He}$ notes that "the Social Contract inspired more trust and veneration than ever were commanded by the Bible and the Koran” ${ }^{\prime 104}$ and this is exactly what he aspires to in his own work. However,

Rousseau was led so far as to view the social state as the degeneration of a state of nature invented by their [the metaphysicians] imagination, which is only the metaphysical analogue of the theological idea relating to the degradation of the human race by original sin. ${ }^{105}$

Comte believed religion reflected a basic truth about man and society, but confused the terms of the debate because of the prevalence of unscientific ideas. Indeed, for Comte the Social Contract is also flawed because, based on metaphysics and the remnants of theology, the legislator's will is "arbitrary" whereas the scientific law of the new social order ought to be based on "observation". ${ }^{106}$ We see how Comte works this out in his treatment of Kant in his later works, but here, crucially, the proximity of Rousseau's

${ }^{102}$ Ibid., pp. 52-53.

${ }^{103}$ Ibid., p. 52.

${ }^{104}$ Comte [1968c], p. 511.

${ }^{105}$ Comte [1968d], p. 553.

${ }^{106}$ Comte [1998a], pp. 82-83, 108. 
ideas to religion accounts for their popularity. Comte's subsequent ambition was to give this theological content positive scientific foundation, while also cloaking his own works in the sort of religious symbolism that proved such a success for Rousseau.

In the System of Positive Polity Comte repeats an argument he had made previously in his essay 'Philosophical Considerations on the Sciences and Scientists', that the philosophies of history of Kant and Herder were among the first to see that "social phenomena, like all others, should be regarded as reducible to natural laws". ${ }^{107}$ While this is clearly a misreading of Kant's theory of ideas and the critical project which underpins it, Comte makes this argument in this way because he wants to show that the revolt of reason against feeling was “disastrous”. ${ }^{108}$ He is no less complementary about Kant's religious views arguing that having used the critical project to dash all belief in "supernatural" ideas he then "made an attempt to re-establish them on the plea of their necessity to society." 109 Comte saw Kant as sincere in his belief, and to a degree he sympathised since this precisely reflected the tendency of thought to move from critical to organic. But crucially, the idea of God provided the promise and morality of order in the absence of convincing science - an absence Comte wants to fill. As we will see this position has an echo in Comte's treatment of the Catholic theocrats. But Comte's critique of Kant goes further still.

It is possible to argue that Comte begins his critique by making the important concession to Kant's metaphysics of the separation of subject and object and the necessary centrality of the epistemological project to positivism. ${ }^{110}$ What Comte argues however is that the ways in which we interpret data are socially conditioned and evolve with our minds over time. Thus Comte argues that all of the human sciences ought to rest on biology, indeed, Chapter III of the first volume of The System of Positive Polity argues that sociology and biology are coterminous but irreducible sciences, with both determined by the laws of physics and chemistry. Our minds have no autonomous natures for Comte and ideas are reducible to matter and to society.

\footnotetext{
${ }^{107}$ Comte [1968d], p. 603, cf. Comte [1998d], p. 166.

${ }^{108}$ Comte [1968a], p. xi.

${ }^{109}$ Comte [1968c], p. 519.

${ }^{110}$ Comte [1968a], p. 356.
} 
Comte argues that while Kant was probably right to specify an objective and subjective element to cognition, he was wrong to see cognition as unmediated by social and biological context. "Cognition is never effective" he argues, "until the outward impression corresponding to it has been repeated sufficiently often." ${ }^{111}$ Comte leans closer to Hume and Locke when he argues that truth bears on the mental construction of a,

conception that shall harmonise with the total sum of impressions received from without. The less distinct these impressions are, the greater is the effort of the mind to substitute its own combinations, which are very subtle and farfetched. When there is a strong desire for a decision, and yet no external facts sufficient to justify it, it is sometimes founded on purely internal reasons, due simply to a strong relation of the Heart upon the Intellect. ${ }^{112}$

The latter is not scientific judgement, and to trust intuitions like this is tantamount to accepting the norms of society which in their early stage are mostly religious. Nevertheless, the effects of this sort of reasoning are observable and therefore phenomenal and have a direct impact on how we think. This conception of the heart and the affective and emotional contributions to the intellect are vital to Comte's system. Moreover, in each reference to Kant, Comte develops critiques of idealism based on arguments against those who deny society and emotion in the name of solipsistic idealism. This is "as injurious to morality as it is erroneous in philosophy”. 113

Comte argues quite clearly and, it has to be said, convincingly, that while the study of animals and humans is in its infancy, human exceptionalism is ill-founded even on the basis of the existing evidence of his time. Thus human functions are particular and a “complex result", rather than an "irreducible” property of human "social evolution”. ${ }^{114}$ Thus, he argues, "the Brain should never be considered apart from the rest of the

${ }^{111}$ Ibid., p. 575.

${ }^{112}$ Ibid., p. 576.

${ }^{113}$ Comte [1968b], p. 29.

${ }^{114}$ Comte [1968a], p. 543. 
organism.”115 The special functions of intellect are what he calls "composite results, due to the combined action of the elementary intellectual functions”. He rejects Kant's ontological dualism of mind and matter arguing that "from the Biological point of view, this dependence of the Intellect on Sensation is perfectly analogous to that of the bodily Functions upon the Environment which controls the whole vital Existence."116 Comte argues that we are ruled as much by our passions as by our intellect. In the final analysis there is a sophisticated causal relationship between our minds and the matter of which it is composed and the social relations which shape and which are shaped by it. In the introduction to the second volume of System of Positive Polity Comte is unequivocal: he argues that "[i]n Biology we now regard all forms of life simply as an evolution, and we discard any notion of creation in the proper sense of that word." ${ }^{\text {117 }}$ Kant's project, it would seem, has by now been completely discarded. But we would be wrong to think this.

\section{The Relation of the Individual to Society: Sociology}

Ejecting God from stories about the evolution of man had serious implications for any discussion of historical providence, a concept which, as I have argued, Comte was quite keen to retain but which had only religious origins. Comte therefore had to find an alternative justification for the teleological conception of history. Comte had the added problem of seeing society as neither good nor bad but stumbling forward to ever higher states of awareness the pinnacle of which, Comte argued, is positivism. The end point is Comte's Religion of Humanity. The question is how did he get there?

If Comte is to justify a return to society and to individual emotions in order to explain cognition and order, he must posit the ontological reality and importance of both. Society and emotion are therefore validated by his law of social statics. Comte argues that social order is a function of the structure of the "Collective Organism", the irreducible aggregate and product of association, and the norms, values and laws which uphold it. These are themselves in turn reducible to the biological, emotive and cognitive functions

\footnotetext{
${ }^{115}$ Ibid.

${ }^{116}$ Comte [1968c], p. 15.

${ }^{117}$ Comte [1968b], p. 2.
} 
of individual humans. Building on the ideas he takes from the theocrats, the theory of the Collective Organism arises from his theory of "Social Forces", which became so vital to Proudhon's thought later. This was by no means an original observation on Comte's part, but Comte's contribution here was to argue that collective force, or the Collective Organism, can only arise where there is the direct control of the purposive intellectual, material and moral force of individuals through institutions. Without this control the collective cannot manifest as one, and anarchy (either capitalist, medieval and military, or rationalist - all of which he despised) would reign.

Following Montesquieu here, Comte presses home the need to embed the origins of force in their environment in order to show how variations in this environment affect the forms of association and thus the sheer plurality of "Collective Organisms". 118 The animating ideas of the collective are what have shaped the intellectual progress of society with each successive evolution of our conceptions of the world evolving inevitably towards positivism: knowledge’s final state. But how does this occur?

\section{The Law of the Three States}

Before I discuss the nature of the law of the three states it is worth saying a few words about Comte's philosophy of history in general. First, Comte argued that history determines society, and chance's role is "grossly exaggerated."119 Comte argues that history follows a law that is internal to it and crucially determined by the individuals and the social forms they create to regulate the shape and direction of progress. The present, he argues, is a necessary outcome of the past and in this sense he breaks decisively from Kant and Rousseau, both of whom explicitly demand we take the real past out of our understanding of the nature of social order.

But Comte remains faithful to Kant when he argues that we need to find the law of historical change in order to be able to live by its dictates in "Harmony". Vitally, the

\footnotetext{
${ }^{118}$ For Comte a key institution in shaping this institutional and ideational force is communal property relations. He argues that private property is vital but the social effects of it ought to be directed by the Priest Scientists and industrialists.

${ }^{119}$ Comte [1998b], p. 95
} 
minimal teleology of the argument remains since for Comte "we shall see that the same course followed by the new system had been necessitated by the situation of its elements at their origin."120 The maximal teleology of Comte's argument relates to the fact that he saw Positivism, the means to ascertain this historical movement correctly, as the predetermined end that Kant had only speculated about. This is teleology mixed with prolepsis and no small amount of egomania on Comte's part. Moreover, free will also completely drops out of his formulation, since it has no meaning if our past conditions our present and our futures have only one predetermined end. The aim of science must be to find the law of our evolution and then instruct others how to live in harmony with it. Comte is quite clear that this law is his 'Law of the Three States', and since Comte was the one to discover it he also believed that he was right to anoint himself the "High Priest of Humanity”.

Comte was quite clear from his earliest works that not only does social history pass through three clearly discernable and pre-determined stages, but so does human psychological evolution between infancy and adulthood. As he first argued in the Plan: "By the very nature of the human mind, each branch of our knowledge is necessarily liable in its course to pass in its turn through three different theoretical states: the theological or fictional state; the metaphysical or abstract state; the scientific or positive state."121 The psychological state of the theological age is characterised by the inability to connect a "small number of isolated ideas" with anything other than supernatural phenomena. In the System of Positive Polity he calls this "the age of fetishism" in which all objects are invested with human qualities. This is a natural and spontaneous human act derived from our affective and empathetic natures, but it has been corrupted by Theologism which made fetishism systematic, institutionalised it in Deification and deliberately hampered our ability to see beyond it. ${ }^{122}$ Nevertheless, and as indeed most believed at this time, the theological age was "indispensable if we are allowed to go further", ${ }^{123}$ mainly since we must recover this affective state and unite it with reason in the final positive stage.

\footnotetext{
${ }^{120}$ Comte [1998e], p. 24.

${ }^{121}$ Comte [1998b], p. 81.

122 Comte [1968c], Chapter 2.

${ }^{123}$ Comte [1998a], p. 81.
} 
The second state is the metaphysical, and this is characterised by the continuing prevalence of religious ideas that move towards positive doctrines. These are necessarily critical doctrines, have their origin in the scientific revolution instigated by the Arabs in Europe and by the subsequent industrialisation of society. ${ }^{124}$ Over the centuries, with observation overcoming faith, critical doctrines were developed to criticise the prevailing order of deference and faith using the tools of the theological era - namely "personified abstractions" - to imperfectly conceive of the Collective Organism. Because they also tended to put too much emphasis on the critical faculties of each single individual, Comte argues that the critical metaphysical stage necessarily unleashed revolutions. This second state is thus an "illegitimate" and a transitory state because it tends towards dissolution. ${ }^{125}$

Comte nevertheless makes the interesting argument that "[t]he chronological order of the epochs is not the philosophical order. Instead of saying: past, present, future, we should say: past, future, present.”" ${ }^{\text {"26 }}$ If we want to know the present we need to look at the past and we need to see that the present is the past's inevitable future. Thus, with the rise of positive science in the Arab world, its spread was an inevitable cause of the metaphysical age and the theological remnants within thought are removed by reference to precise and positive scientific doctrines based solely on observation and the testing of hypotheses.

\section{The Aims and Purpose of Positivist Sociology}

Comte's Positivist Sociology is not just a holistic philosophy of science, nor is it simply a holistic approach to the objects of science: it is also a theory of human intellectual evolution, our place in the cosmos and the justifications for a particular type of social order derived from the findings of all of the above. ${ }^{127}$ Morality derived from our passionate and innate emotions are central to Comte's formulation, and in this he echoes Fourier and rejects the rationalists and the idealists completely. Taking these new realities seriously, then Comte took it upon himself, from the very outset of his career, to

\footnotetext{
${ }^{124}$ Ibid., p. 93.

125 Ibid., p. 81.

126 Ibid., p. 105.

${ }^{127}$ On his holism, naturalism, positivism - all of which denote the unity of the sciences and of nature - see Comte [1998d], p. 161.
} 
reconstruct the whole of Enlightenment thought so as to guarantee that order and progress not only coexisted, but to show that they always had - a theory of the grandest and most totalising variety. Eerily echoing Kant, Comte argued that

Any system of society, whether for a handful of men or for several millions, has as its final object to direct all individual powers towards a general goal [of activity]. For society can only exist where a general and combined action is exerted [...] It follows from this consideration that the clear and precise determination of the goal of our activity is the first and most important condition of a true social order, since it fixes the direction in which the whole system is to be conceived. ${ }^{128}$

Positivist Sociology was just such a system of thought, and it fell to Comte to determine the positive plan of post-Revolutionary social regeneration.

The formation of any plan of social organisation is necessarily composed of two series of operations, totally distinct in their object as well as in the kind of capacity they demand. One, theoretical or spiritual, has as its goal the development of the seminal idea of the plan, that is of the new principle according to which social relations must be co-ordinated, and the formation of the system of general ideas intended to serve as a guide for society. The other, practical or temporal, determines the mode of distribution of power and the system of administrative institutions which are in closest conformity with the spirit of the system as settled by the theoretical operations. ${ }^{129}$

Comte argues that, given history has pushed industrialists and scientists to the forefront of society and that this period stood at the end of history, they ought to be its directors from here on in. The people should be made aware that their direction by the vanguard is in their best interests and that they ought to work for the industrialists who are directed by the scientists in society's interests - not their own individual interest. But if any

${ }^{128}$ Comte [1998a], p. 66.

129 Ibid., p. 65 (emphasis added). 
individual should be found in one of the lower classes with any theoretical prowess, he should be encouraged to become a scientist, because individuals are not subservient to the new conception of their fixed class. This is perhaps a reason why Proudhon was invited to join Comte at the forefront of the Religion of Humanity. Crucially however, this newly divined "nature of things [...] absolutely prohibits freedom of choice by showing, from several distinct points of view, the class of scientists to be the only one suited to carry out the theoretical work of social reorganisation." ${ }^{130}$ Furthermore, since civilization follows only one, predetermined and absolute law, "which dominates all particular human differences” asserting individuality is quite simply a waste of time. ${ }^{131}$ In Comte’s system while the individual is vital to the Collective Organism, politically it then becomes absolutely subservient to it, just as Rousseau and Kant had argued beforehand. The scientists must work out a way of overcoming this paradox, indeed, "the critical prejudice that conceives moral sovereignty as an innate right in each individual would be insurmountable by anyone other than them.”132

As Pickering has pointed out, “in a sense Rousseau's Legislator lived on in Comte's spiritual power", ${ }^{133}$ which is an understatement, and as Manuel has argued, "[t]he impression is inescapable that in the positivist religion there is a total loss of personality as man is merged in the perfect transcendent unity of Humanity." "134 The question is: how does this come to pass and to what extent ought this to be universal?

\section{War and the European Civilising Mission}

Comte, following Condorcet and Kant to name but two, argued that war has always been the motor of human psychological and social development. War is initially inevitable because it is instinctive, indispensable because it is stimulating of the intellect, and providential because it drives us towards industrial innovation and the further development of positive doctrines. This movement can be seen to have begun and faltered in ancient Greece. Here Comte argues that because of the instinctive evolution of

\footnotetext{
${ }^{130}$ Ibid., p. 76.

${ }^{131}$ Ibid., p. 97.

132 Ibid., p. 77.

133 Pickering [1993], p. 707.

${ }^{134}$ Manuel [1965], p. 281.
} 
a militaristic Athenian society, a theological stage of development did not arise and the metaphysical stage arose early due to the proto-perfect division of society between workers as slaves, industrialists as the military cadre and the scientific or aristocratic elite. ${ }^{135}$ But more generally Comte argues that war creates large societies which spurred the types of association necessary for the evolution of positivism. ${ }^{136}$ Nevertheless, while war and conflict are supremely (if secularly) providential in the history of human rational evolution, he is clear that in the positive age the

only means by which human association can be carried to its fullest extent is [through] Labour. But the first steps in the development of labour suppose the pre-existence of large societies; and these can be founded only by War. Now the formation of large societies came to pass naturally from the spontaneous tendency of military activity to establish the universal dominion. ${ }^{137}$

The course of history is thus driven by "two very powerful impulses: the repugnance he [man] feels for any daily labour; and a downright taste for destruction." ${ }^{138}$ These natural compulsions to war also lead directly to industry through the inevitable consequences and imperatives produced by a wholly natural course of action in mankind. Thus war is as much a vital aspect of Comte's "Fundamental Theory of Human Evolution”"139 as it is to Kant's “Idea”. Interestingly, and in complete contradistinction to Rousseau and Kant but following Fourier quite closely, Comte argues that with the evolution of industry and the decline of the martial impulse "[t]he steady amelioration of the lot of women and the gradual extension of their influence, furnish the best measure of this progress, both in its negative and positive shapes, towards true moral perfection.”" ${ }^{\text {"140 }}$ Thus the closer we get to Comte's perfect social hierarchy and Collective Organism, the freer women will be. Central to this is the development of industry and a liberal, positivist ideology. If ever Second Empire anarchist misogynists like Proudhon needed an excuse to keep women

\footnotetext{
${ }^{135}$ Comte [1998d], p. 175.

${ }^{136}$ Comte [1968c], pp. 46-54.

${ }^{137}$ Ibid., p. 49.

${ }^{138}$ Ibid., p. 47.

139 Ibid., p. 55.

${ }^{140}$ Ibid., pp. 57-58.
} 
repressed, this was it. But we ought not to overlook that Comte never argued more than that women should be seen as glorified social barometers. ${ }^{141}$

Echoing Kant, but taking his own ideas elsewhere, Comte argues that "if we make due allowance for the difference in timespan between the life of the species and that of the individual”, bear in mind also that "we can accelerate or delay the development of an individual instinct”, social psychological engineering is fully possible and wholly warranted by the new nature of civilization. ${ }^{142}$ Indeed, he argues in the essay on the nature of the future spiritual power that government by force is warranted where rational acquiescence is not forthcoming and that this will change people's minds over time. ${ }^{143}$ This is premised on an important argument for a temporary dictatorship to institute the spiritual power, which explains his entreaty to Tsar Alexander II of Russia in the dedication to the third volume of The System of Positive Polity and his view that Napoleon III's dictatorship promised much for the industrialists - which it did.

He continued that the whole of Western Europe must be united under this organic doctrine with the balance of Power, a symptom of the critical doctrine, abolished forever. France would become the centre of the civilised world with Paris as her hub. The union and uniformity of religion and of social organisation and the dissolution of all petty differences must be proven to be the only rational future for Europe if it is to avoid the anarchic horrors which a persistent critique promise. The key to this is to ensure that Scientists are not swayed by politics; that they base all their promises for society on observation and positive organic truths; that they share a common language and outlook. Only thus can the historic destiny of Europe’s scientists be realised.

It is worth concluding with the words of Manuel, easily the best analyst of Comte's ideas, that "[i]n no other modern philosopher was the rationalist fantasy so inextricably bound up with private life,”144 “In short”, Raymond Aron has argued "he made an exact diagram

\footnotetext{
${ }^{141}$ D’Herricourt's scathing 1864 critique of Comte argues the following: "The function of woman is to render man moral; a task which she can perform well only in private life; all social and sacerdotal [by the latter she means within the Positivist Religion] functions are therefore interdicted her.” [1981], p. 121

${ }^{142}$ Comte [1968c], p. 98.

${ }^{143}$ Comte [1998d], p. 213.

${ }^{144}$ Manuel [1965], p. 251.
} 
of his dreams, or of the dreams each of us may invent in those moments when he takes himself for God", ${ }^{145}$ and demanded that the whole of Humanity conspire to realise them. He was also the father of Positivism and Sociology, and his legacy animated much social theory, ${ }^{146}$ not least twentieth century scientific communism.

\section{Conclusion}

The main conclusion of this chapter is that for Rousseau, Kant and Comte war, imperialism and colonialism, the bringing of the uncivilised into the realm of the civilised, were of paramount importance to extending the rule of law, the promises of real liberty and ensuring the teleological march of history culminated in the way they thought it should. Their focus was the internal make-up of states and if this could be perfected not only would war eventually peter away, but we would, through harmonising our natures with the best political institutions, fulfil our destinies on earth. Echoes of less sophisticated versions of much the same story can be heard from the previous chapter. The turn inwards, to the internal make up of the state, and seeing international politics as at best something to overcome in the interests of the very same state, seemed to exclude a full analysis of the international system as perhaps sui generis. What I want to close with is the idea, or the proposition, that ethically, at least from the historical vantage point of the twenty-first century and the crimes of totalitarianism and colonialism, Proudhon's thought would have to struggle to advocate worse.

The question remains whether he can sustain his anarchism in a philosophically sophisticated way, while remaining internally coherent and consistent, and rationally compelling. What I will show is that Proudhon turns Rousseau's romanticism into his own brand of humanism. He also uses Rousseau as the foil for his arguments against absolutism and the state. He takes Kant's philosophy of right as the foil for all his arguments against the liberal and idealist conception of law, and engages with his philosophy of history at the same time. Proudhon use of Comte is clear in his adoption of the three-state theory of history, the development of a relational ontology and the notion

\footnotetext{
${ }^{145}$ Aron [1968], p. 90.

${ }^{146}$ See, for example, Scharff [1995].
} 
of forces. Proudhon's criticism of Comte reflects his criticism of collectivism generally: it absorbs or erased the individual almost entirely. It is to the first part of the critique that I now turn. 


\section{Part 2: Exegesis}




\section{Chapter 4}

\section{Justice and Order}

The people have until now done nothing but pay and pray: we believe that the time has come for them to PHILOSOPHISE ${ }^{1}$

\section{Introduction}

The previous three chapters perform one important function. They substantiate and contextualise the approach I will now take to Proudhon's writings on world politics. I hope to be as close a reader of Proudhon as I have been of Rousseau, Kant and Comte, and I will use my analysis of the politics of the nineteenth century to contextualise Proudhon's ideas in their times. This, the second half of the thesis, will do three things. In this chapter I will show how Proudhon's thinking about world politics follows from his engagement with Kant and Comte. In chapter five I will discuss Proudhon's theory of world politics and show how it is linked to his political and social philosophy. In chapter six I will show how his normative approach to federalism is a logical continuation of his thinking more generally. By showing why and how Proudhon constructed his political philosophy in the way that he did, how he approached war and peace and why he believed war could be overcome, I will be linking this half of the thesis to chapter one. I will show why Proudhon believed the European balance of power should be entrenched as opposed to overturned - no matter in whose interests. Secondly, I will present Proudhon's theory of how this balance of power had arisen in the first place. Thirdly, I will show how he would have reconstructed our principles of social organisation along federal and mutualist lines, and what he would have done with an entrenched system of European power.

\footnotetext{
${ }^{1}$ Proudhon [1988/1990a], p. 7.
} 
This chapter sets out the foundation of Proudhon's response to nineteenth century thinking about world politics. I focus exclusively on the 1860 edition of De la Justice dans la Révolution et dans l'Église, études de philosophie pratique. At over two thousand pages, this work is without doubt Proudhon's summary statement of his thinking about philosophy, politics, economics, religion and history up to that time. The chapter proceeds in the following way. In the first part I provide a very short history of the writing and publication of the text to give some idea of what Proudhon was trying to do by writing it. In part two, I provide a brief and broad overview of the secondary literature and its engagement with what is undoubtedly Proudhon's magnum opus. I use the context provided in the previous chapters to illustrate ways of providing better readings of this text. This is a technique I will also repeat at the beginning of the following two chapters. In the third, main section of the chapter, I turn to one specific part of the four volumes of the work: the Petit Catéchisme Politique is something of an epilogue to the fourth of the twelve etudes and is, I will claim, as good a summary of Proudhon's thinking as is possible to find anywhere in his oeuvre as a whole. I will briefly outline the almost religious, but more likely ironic intent of the title of this short forty nine-page section and show how it is an excellent summary of Proudhon's thinking on the source and nature of justice to be found. Since I also argue that De la Justice is a summary of Proudhon's thinking up to that point, it is possible to argue that the 'Petit Catechisme' is a useful key to his work as a whole. It thus warrants extensive analysis and contextualisation. This third section will be divided according to the five 'Instructions' of Proudhon's catechism. I deviate from his analysis only to more fully explain his thinking, and do so by drawing on De la Justice as a whole. I conclude with a brief summary of Proudhon's theory of justice, and point out a number of questions that Proudhon left hanging in this work with the deliberate and explicit intention of answering in a future more detailed analysis of war and peace. This will of course link the narrative to the following chapter.

\section{The Text}

The most recent edition of De la Justice spans 2358 pages and there is little in nineteenthcentury politics, philosophy and society that Proudhon does not touch upon. It is divided between twelve separate but interconnected études; each deals with a separate topic, 
ranging from work, to love and marriage, to the state, ideas and more. In this sense, it achieves Proudhon's stated aim, cited in the introduction to the previous chapter, of compiling “[u]ne sorte d'encyclopédie dont le principe, la loi, la méthode, la fin, est le droit" - an aim that perhaps does make him the illegitimate child of the Encyclopaedists as Metternich claimed. It is unquestionably Proudhon's magnum opus. As a whole it is a monumental effort, but to write over two thousand pages of original manuscript in two years meant it was written quickly. As such, it displays both the weaknesses and the sheer genius of Proudhon's thought and style. Moreover, like so many of Proudhon's works, it began life as a pamphlet. This particular one aimed at refuting a scathing and "mendacious lampoon”,2 of Proudhon's life penned by Eugène de Mirecourt. De Mirecourt had approached the Archbishop of Besançon, Cardinal Matthieu, for details of Proudhon's early spiritual life and childhood. What Cardinal Mathieu perceived as Proudhon's lack of childhood piety was used by de Mirecourt to explain Proudhon's assumed atheism and all manner of other irreligious flaws. De la Justice is thus at root a pamphlet-style attack on Catholicism, personified by the Archbishop of Besançon, and the beginning of each of the twelve études responds directly to many of the claims made by his biographer. This feature of the work provides it with a polemical, rhetorical and autobiographical style that is rarely, if ever, seen in works of political philosophy.

De la Justice should also be seen as the culmination of twenty years of research into the nature, source and reality of justice. La Guerre et la Paix (1861), Fédération et l'Unité en Italie (1862) and Si les traités de 1815 ont cessé d'exister (1863) which follow it, explain how justice changes and becomes ordered or structured over time, and the various effects structures of moral norms (such as nationalism) have had on society. Du Principe Fédératif (1863) and De la Capacité Politique des Classes Ouvrières (1865) complete the list of Proudhon's last major works by setting out his vision for achieving a more just future. Whichever way one looks at it, De la Justice is the keystone of Proudhon's intellectual output.

The first edition of De la Justice was published on April 22, 1858. By this time it had expanded to three volumes of 1675 pages. The initial print run of 6000 copies sold out

\footnotetext{
${ }^{2}$ Woodcock [1956], p. 196.
} 
within days - an unqualified success by any standard for a work of this type and length. Haubtmann reports that three further print runs were ordered simultaneously and might well have sold a further 30,000 copies in the first year of publication had the authorities not slammed that door shut by censoring the work and fining the publishers. The work was seen by the authorities, who could not possibly have read it in the time it took them to censor it, to have been an attack on public morals and order. Nevertheless, Proudhon took comfort from the fact that copies were being bought by people who couldn't read but believed they should own a copy, but he protested at the huge black market price other copies were being sold at. ${ }^{3}$ Unfortunately, whatever delight he may have experienced at the work's success had to be enjoyed from Belgium because, facing another prison sentence, he chose to go into exile.

Broadly speaking, the work is a direct engagement with the social problems of his day that uses the tools and approaches of classical metaphysics, and Comte's positivist sociology to understand what Comte called "social statics". What the work lacked, and what La Guerre et la Paix later provided, was the analysis of how things change. Following Comte's law of the three states, each étude is structured methodologically in the following way: first, Proudhon outlines the role of the Church in providing a first, but remarkably enduring, rationalisation of social order. Metaphysics are treated incidentally as a bridge between the old religious order (while retaining key aspects of it) and the new revolutionary era; and finally the revolution is portrayed as embodying potential for the future. Throughout the work, Proudhon highlights where others (be they church leaders, philosophers, politicians or social critics) are going wrong, and so the work contains both abstract philosophical reasoning and engaged political critique.

In the new preface to the second edition, published two years later, Proudhon provided what he argued was a key to the work as a whole. Specifically, in section V of this preface he gives a brief summary of Kant's system of the categories and how they are the, according “l’Ecole”, “indispensables pour la compréhension des choses”. However, following Comte he then goes on to argue on the following page that while the categories, as he understands them (and not as Kant explained them) are the "sine qua

\footnotetext{
${ }^{3}$ Haubtmann [1988b] p. 95-96.
} 
non de la parole et du savoir" alone they are sterile and demand the positive doctrines of science to elevate them beyond simple "metaphysics". He is clear that "Toute science est essentiellement métaphysique” but he argues that this metaphysical element leads to solipsism or "somnambulisme". Good science, he thus claims (somewhat disingenuously), has the real world as its object, takes the real world for its cue and cares little for the fineries of epistemology.

He then goes on to argue, as he had been arguing since the publication of De la Création de l'Ordre, that his theory of ideas demands a relational ontology, between object and subject, between knower and known, and demands, finally, and contrary to Comte, that all philosophy ought to be practical and open to all. ${ }^{4}$ In what might be read as a direct rebuke of Comte's denunciation of the critical approach to science, Proudhon closes this preface with the following call to arms:

Quel sera leur [les cosmopolites de la révolution] drapeau? Ils n’en peuvent avoir qu’un: la Révolution, la Philosophie, la Justice.

La Révolution est le nom français de l’idée nouvelle:

La Philosophie est son nom germanique;

Que la Justice devienne son nom cosmopolite. ${ }^{5}$

By taking justice to be his motto Proudhon subsumes all to the search for it. Whereas justice dropped out of Comte's philosophy (Order and Progress alone now the motto adorning the Brazilian flag), and whereas justice was for Kant a duty derived from the categories of the mind, for Proudhon it is real, social and evolved. He is clear, as I will show, that conscience and the liberty of the will are, as Rousseau and the romantics put it before him, an important corrective to the sterility of reason. But he is also clear that, as I will show here and in the following chapter, our passions are in symbiosis with our reason and both are necessary but, crucially, insufficient. By this I mean that Proudhon refused to countenance that we could find transcendental foundations in either our passions (pace Rousseau) or our reason (pace Kant) or in science (pace Comte). Justice,

\footnotetext{
${ }^{4}$ Proudhon [1988/1990a], pp. 21-27.

${ }^{5}$ Ibid., p. 83.
} 
Proudhon argued, is what drives us and trying to understand what justice is, is the purpose of this work and also of this chapter.

It is no coincidence that while eleven of the twelve constituent études were also significantly revised and expanded in this second edition, only one remained without the extensive appendices of the others: the ninth étude, 'Progrès et Décadence'. This was the one subject that, as I have shown in the previous chapter, by its engagement with providence, teleology and the role of the state in social change, constituted the core of the moral and political philosophy of Rousseau, Kant, and Comte. What might account for this refusal to revise it then? In July 1860, during the final revisions for the second edition, Proudhon noted in a letter to Gustave Chaudey that the ninth étude was "une des plus difficiles par la nature de la question; près de vingt pages ont été ajoutées ou complètement refaites."6 He nevertheless chose not to expand on the subject as considerably as he had the others here but chose to write stand alone works on the subject instead. As Hoffman has argued (if somewhat dismissively), La Guerre et la Paix is "philosophy of history more than anything else". Following Rousseau, Kant and Comte, he used ideas of progress and decadence to make sense of the role of morality in politics and both in history. Proudhon also turned to macro processes, and as with Comte and Kant, war was his case study. As I will show at length in the following two chapters, each of the works that followed De la Justice (with the exception of his works on art, taxation and women), were deliberate attempts to answer the questions his particular approach to the question of justice in history, and progress and decadence, left unanswered.

\section{The Secondary Literature}

Strangely, De la Justice has received relatively little attention outside the main monographs on his thought - particularly in the English language literature. ${ }^{8}$ By and large, the snippets of secondary literature are also unhelpful. For example, Peter Marshall has argued that "Proudhon was a deontologist in that he believed intrinsic values are not

\footnotetext{
${ }^{6}$ Proudhon [1998b], p. 198.

${ }^{7}$ Hoffman [1969], p. 261. Hoffman, however, misses the significance of this and dismisses the work almost out of hand as I will show in the following chapter.

${ }^{8}$ The one exception is Harbold [1969].
} 
means to an end, but ends in themselves". ${ }^{9}$ This I believe is an inadequate framing of a far more complex moral philosophy. But Marshall is not alone. Steven Vincent has also argued that the "absolute" was never far from Proudhon's mind and that the search for “absolutes" little further. ${ }^{10}$ Vincent is explicit that he does not engage with De la Justice "in detail"," but his limited analysis reinforces unhelpful readings of Proudhon's thought.

Others, like Hoffman, read Proudhon's moral philosophy to be rationalist coupled, like Kant's he argues, to an "essential optimism about human nature". ${ }^{12}$ Of course, as I have shown, this was not even Kant's position let alone Proudhon. However, Hoffman is correct to see Proudhon as understanding morality as a social force and that it only has meaning within this domain. But he also reads Proudhon as arguing that the "rules a man must live by must be entirely internal in origin, stemming from his rational faculties. In no other way will men act morally". ${ }^{13}$ This reading of Proudhon as a Kantian, while closer than arguments that preface Proudhon's metaphysics with Hegelianism, is unhelpful, but very prominent in the literature. William Harbold thankfully complicates this reading by arguing that Proudhon's theory of justice is something of a "synthesis" of conscience and will, instinct and reason, irreducible to either and superior to their sum. ${ }^{14}$ Crucially, Harbold also shows that this synthesis only has value in human social relations, governed as we are by more than base instinct while we are also driven by a natural concern for our fellows. Neither the Kantian nor the "synthesis" approach to Proudhon's philosophy tells us exactly how this process works or how we might deduce the principles of right moral action from society, our conscience and our reason; nor do we get any sense of where Proudhon's ideas came from. Arguably what is needed is a more rigorous, analytical approach.

Unfortunately, the only existing analytical approach to Proudhon's thought is even more misleading. Ritter has argued that Proudhon equates justice with "respect” for human

\footnotetext{
${ }^{9}$ Marshall [1992], p. 249.

${ }^{10}$ Vincent [1984], p. 122.

${ }^{11}$ Ibid., p. 225.

${ }^{12}$ Hoffman [1972], p. 248.

${ }^{13}$ Hoffman [1972], p. 229.

${ }^{14}$ Harbold [1969], p. 737.
} 
dignity and that all of his theory can be deduced from this guiding assumption. However, before Ritter can approach the subject in this deductive way he first had to jettison the social ontology that Harbold and Hoffman rightly point to. They both see Proudhon as something of a practical moralist in his context, but Ritter is clear that in his view this is problematic. He argued that,

In his [Proudhon's] published writings, and even in his letters, sociological propositions are rare and incomplete. We are told repeatedly that "the stimulus of society” affects men's behaviour and ideas, but learn little about the scope and limits of this stimulus, or why and how it occurs. The hints of a theory of social psychology in Proudhon's published work whet our curiosity without satisfying it. ${ }^{15}$

This would suggest that social forces actually play little role in Proudhon's thinking about justice. But Ritter claims far more than this. He argues also that there are two dominant schools of interpretation when it comes to Proudhon's ideas, particularly amongst his French commentators such as Bouglé, that are divided between those who prioritise Proudhon the moralist, and those who prefer Proudhon the sociologist. ${ }^{16}$ Ritter claims that this is a false distinction since sociology does not feature extensively in Proudhon's thought. Turning to Proudhon's (then) unpublished Cours d'Économie Politique, he argues can help to "fill some gaps" and "remove [...] ambiguities”. ${ }^{17}$ But even with this analysis, Ritter concludes that “[j]udged by its own pretensions, Proudhon's theory of morals is a failure". ${ }^{18}$

However, Ritter's analytical critique, one with takes the deductive coherence of propositions as the measure of Proudhon's overall coherence, could only apply if Proudhon was indeed a poor sociologist. If Proudhon were to have provided evidence of the role of society in shaping our conceptions of justice, much as Comte had done before

\footnotetext{
${ }^{15}$ Ritter [1969], p. 34. Ritter claims that Célestin Bouglé, the eminent Sorbonne historian of sociology, ignores the normative element in Proudhon's work and that the sociological interpretation of Proudhon's work does not allow us to understand his theory of morality [Ibid], p. 11, 84.

${ }^{16}$ Ibid., p. 84.

${ }^{17}$ Ibid., p. 85.

${ }^{18}$ Ibid., pp. 92-93.
} 
him, then he could not be judged according to the criteria of analytical philosophy. Induction and deduction are mutually exclusive in this context. One cannot have it both ways, and so Ritter forces Proudhon into an analytical box he was never meant to occupy. Ritter's neo-Kantian approach to political theory also shaped his approach to the history of ideas with, arguably, utterly misleading consequences for our understanding of Proudhon. Proudhon brings far more to the subject of morality than Ritter's rationalist ontology and deductive and rationalist epistemology recognises as causal, analytically useful and normatively valid in shaping moral theory. In short, Proudhon brings in the real world. In admitting Proudhon's realism, ${ }^{19}$ Ritter sees this, but he then judges Proudhon according to a set of epistemological criteria that, as I will show, Proudhon himself criticised. Either one is deductive and bases one's arguments on the internal consistency of theoretical propositions. In this instance, ontological or sociological propositions are validated not by the evidence but by their internal consistency with other propositions. This is Ritter's reading and analysis of Proudhon. The alternative is to be inductive and base ones ideas about justice (for example) on the empirical evidence, taking ontological questions about the nature of the world to be prior, and thus warranting a pluralist approach to epistemology. Theoretical propositions would thus be validated by the evidence not their internal consistency. Because he approaches Proudhon's theory of morals deductively, Ritter conflates method with evidence and simply cannot demonstrate the richness of Proudhon's theory.

What we should take from this controversy is that there is disagreement and a lack of clarity in the analysis of Proudhon's theory of justice in relation to its ontology and methodology - not to mention what it actually consists of. As should be clear from the previous chapter, no theory of justice comes without this ontological and methodological baggage, however, with Proudhon's thought this is confounded by the historiography of his thinking which usually has him pegged as either a poor Hegelian/Kantian or, as Amoudruz’ analysis suggests, philosophically illiterate.

\footnotetext{
${ }^{19}$ The second chapter of his book is titled “The Realistic Basis of Proudhon’s Political Theory”.
} 
De Lubac presents perhaps the best de-bunking of the former myth to date $\mathrm{e}^{20}$ and as he shows, and Vincent has supported, ${ }^{21}$ if one is to understand Proudhon's ideas we need to see him as a close reader of Kant, not Hegel. But de Lubac is also somewhat confusing. He argues that,

his method, however hostile to metaphysical abstraction, was the very reverse of any Empiricism. It was equally remote from Auguste Comte’s Positivism and Marx’s historic Materialism [sic]. Although Proudhon detested the word it was an "Idealism", too, in its own way. Neither would it be impossible to link it up with Kant’s Moralism. ${ }^{22}$

This paints something of a confusing picture of Proudhon's thought, but it does link it nicely with the influences I claim were central to his intellectual development. It is the aim of this chapter is to clear up this confusion and give a more detailed account of his theory of justice. If justice was the central animating concept of Proudhon's thought, and it is clear to all that it was, how he approached the issue is of central importance to our understanding of his theory. If we get that wrong, as I believe Ritter has, our analysis of his thinking will be no less flawed. Thus, the aim of this chapter is to use the 'Petit Catéchisme Politique' to clear up these confusions, provide the exegesis of this aspect of his thinking and also a preface to the substantive analysis of international relations to follow. I want to show that, contrary to Ritter's analysis, Proudhon's theory of morality is not a failure if we take his sociological pretensions seriously rather than dismiss them. The evidence in support of this approach can be found, summarised for all to see, in his magnum opus.

\section{The 'Petit Catéchisme Politique'}

As I will now show, the 'Catéchisme' is a re-working and fully expanded version of Comte's theory of forces in System of Positive Polity. While the religious debt of the title

\footnotetext{
${ }^{20}$ De Lubac [1948].

${ }^{21}$ Vincent [1989], p. 94. Vincent continues that '[t]he influence of Marx on Proudhon was nil'. An analysis I would support.

${ }^{22}$ De Lubac [1948], p. 143.
} 
has clear precedent, it is also a critique of Comte's own catechism. The aim of Proudhon's work is to emancipate thought from the clutches of religion and, when expressed with simplicity, is designed as a tool for individual and social emancipation contra Comte's Priest Scientists. The Five “instructions” of the catechism reflect this ambition. The first seeks to outline the nature of social power. Central to this is his theory of the source and nature of justice, as I will show. Proudhon accepts the social origins of justice and order, but sees individual agency as central to society. The second instruction turns to how social power is appropriated, exploited and alienated. This is the basis of Proudhon's theory of injustice and is a socialist critique of modern society. The third instruction turns to the evolution of religion as the original source of this injustice. Proudhon argues that the alienation of individual and collective force to the Church prefigured what was to come with the modern state, the rise of Comte's technocratic and scientific elite, and industrial capitalism. ${ }^{23}$ Instruction IV turns to the promise of the revolution and the awakening of collective, social power. The final instruction uses his approach to engage with various issues of the day. I will now turn to each in turn.

\section{"Instruction I: Of Social Power Considered in Itself”"24}

In trying to explain the source of social power Proudhon discusses four important concepts. The first is the reality of "la force collectif" or collective force, which needs to be understood in relation to the second concept: "la raison collectif" of collective reason (I will use the English translation henceforth). Together these two concepts, taken largely from Comte, help Proudhon understand how the individual creates society, how society is as real as the individual, and how society influences the individual in important ways. I develop this analysis to give it its moral and juridical formulation in the third section. Here I turn to the source and nature of justice. Proudhon's theory of justice corresponds with his prior theory of forces. It is a significant development of Comte's formulation because it shows how right and justice emerges from force rather than being subservient to it. Taking Rousseau and Fourier's theory of the passions seriously, Proudhon argued

\footnotetext{
${ }^{23}$ Proudhon tended to use the term "industrial feudalism” rather than industrial capitalism. I will discuss this in detail in chapter six.

${ }^{24}$ Proudhon [1988/1990b], p. 693.
} 
that justice had real, human and passionate roots. This also undermines any rationalist foundation to morality. Comte used the idea of force to provide an organic conception of a hierarchically structured society which would be controlled from above, and used his philosophy of history to support it. Proudhon breaks decisively with all three in his recognition and advocacy of a primordial "droit de la force" or right of force. An analysis of this right will be provided in the final part of this section. Proudhon argued that this right of force had its cradle in the family. What this final discussion will begin to show is that his sexism underpins his entire philosophy.

\section{Collective Force}

Proudhon begins by looking at "Pouvoir Sociale", and the key to this social power, he argues, is "Force Collectif" and the reality of the social being or "I'être social". In accordance with his relational ontology outlined in the preface to the work, Proudhon argues from the outset that collectivities take their force from their relational law, which is to say that collective force is proportional to the complexity of the internal relations that constitute the units, and the relations in which the social beings are enmeshed. Even when looking at units Proudhon argues that these ought to be understood according to their constitutive forces, which ought only to be understood in their relation to other forces since, like Kant he argues that the thing in itself cannot be known.

Force on the other hand can be understood as "pouvoir" or a purposive power, or it can be understood to be passively resistant by its "inertia". ${ }^{25}$ In the fourth "Instruction" Proudhon develops this point a little further. Again he argues that forces can only be made intelligible within a relational ontology. ${ }^{26}$ Therefore, presumably, everything which exists is constituted in and by relations of force. Thus, what constitutes 'existence' is secondary to how existence is constituted, which for Proudhon is done relationally and through force. Recalling the discussion of the previous chapter, the parallels are clear: in taking this line of argumentation Proudhon is following Comte, who, he argues, "a fait du

\footnotetext{
${ }^{25}$ Proudhon [1988/1990b], p. 693.

${ }^{26}$ Ibid., p. 723.
} 
rapport la base de son positivisme, et exclut en son nom la métaphysique et la théologie."27

For Proudhon, the confluence of forces, of things and relations, produces a reality which is more than the sum of its parts. ${ }^{28}$ So, for example, workshops, collectives of social and individual relations, are superior to the sum of individual workers within them, because “le produit de ces individus ainsi groupés est fort supérieur à ce qu’eût été la somme de leurs produits particuliers, s’ils eussent travaillé séparément”. ${ }^{29}$ This was an argument he had been making for nearly twenty years, but since De la Création he had come to argue that the relations which compose a being define it, and from this one can state that "les êtres collectifs sont des réalités au même titre que les individus. " ${ }^{30}$ It is thus that Proudhon argues that "l'être collectif n'est pas un fantôme, une abstraction, mais une existence.”31 In sum, what we see here is that, in contemporary parlance, Proudhon has a relational ontology that holds that levels of social power and organisation are emergent and irreducible. ${ }^{32}$ What Hall argues is that Proudhon may in fact be "one of the first social thinkers to attempt the primitive synthesis of these levels of social reality". ${ }^{33}$

We are already leagues away from Ritter's analysis, as should be clear. Proudhon argues prosaically that “[c]'est un prêtre qui l'a dit, l'homme s'agite et Dieu le mène”34 the element of truth within this is that society is causal. Less rhetorically he argues further on that “[o]utre l’influence reçue par la génération, l’action de la société sur l’individu est immense. Il en résulte que l'homme, dans aucun de ses actes, dans aucun de ses sentiments, dans aucun de ses prédispositions et des virtualités de sa nature, n’échappe complètement à cette action.”35 Thus, for Proudhon collective force, while originally the issue of individual action, nevertheless feeds back onto the individual shaping and

\footnotetext{
${ }^{27}$ Proudhon [1988/1990c], p. 1140.

${ }^{28}$ cf. Noland [1968], Hall [1971].

${ }^{29}$ Proudhon [1988/1990b], p. 694. cf. Proudhon [1994], “Chapter three: "Labour as the efficient cause of the domain of property".

${ }^{30}$ Ibid.

${ }^{31}$ Ibid., p. 724.

32 cf. Noland [1968], p. 40.

${ }^{33}$ Hall [1971], p. 32.

${ }^{34}$ Ibid., p. 719.

${ }^{35}$ Ibid., p. 1565.
} 
constraining him or her in important ways. This more material social ontology has its ideational corollary in collective reason to which I will now turn.

\section{Collective Reason}

Collective force, as we will see, comprises the key concept in Proudhon's approach to the material relations in society. "Collective reason", on the other hand, refers to the emergence of moral and ideational norms in society. However, to account for the irreducible nature of collective norms, Proudhon needs a notion of the purposeful and reasoning individual. For Proudhon all individuals are rarely anything but absolutist when it comes to their own moral norms. However, the confluence and unification of divergent moral norms through compromise and contestation for social ends, produces a moral reality that is irreducible to the individuals who create it. This is "[u]n rapport du commutation entre des forces, et comme ce rapport est aussi lui-même une force, une réalité.” 36 The porous and changing nature of ideologies and collective myths might be understood in this way. Ideologies have fuzzy edges because of the plurality of views out of which some sort of coherence emerges. And, once people stop discussing and fighting for these ideas, their existence recedes into memory or changes into something else.

Proudhon is clear that collective reason is not reducible to collective force, although they are related as we will see below. However, collective reason is directly related to individual reason because it is emergent from it and relatively regulative of it. This area of contestation between individual absolutes and collective reason produces the norms which stipulate the parameters of the contest. There are occasions where Proudhon seems to vacillate between a belief that collectives are simply the sum of its parts and more than that, and much of his discussion about the relationship between the individual absolutes and the collective absolute is sometimes verbose and confusing. What he is clear about however, is that "des idées synthétiques”, which arise from the confluence of opinion and the balancing and compromise of positions, are "très différentes, souvent même très inverses, des conclusions du moi individuel [...] Et cette conversion n'emporte pas,

\footnotetext{
${ }^{36}$ Proudhon [1988/1990c], p. 1256. Only a very brief discussion of Proudhon’s extensive discussion of the nature and composition of the reality of ideas can be had here. See the seventh Étude, 'Les Idées', for further details.
} 
remarquez-le bien, condamnation de l'individualité; elle la suppose.”37 Contrary to Comte's near elimination of the individual, and following Kant here, Proudhon argues that it is right to argue that "la fin de l'homme est en lui-même". ${ }^{38}$ The key is that, for Proudhon at least,

De même que nous avons vu le concours des forces produire une résultante différente en qualité des forces qui la composent et supérieure à leur somme; de même le conflit des opinions engendre une raison différente de qualité et supérieure en puissance à la somme de toutes les raisons particulières qui par leur contradiction la produisent. ${ }^{39}$

This collective reason, something he also calls collective conscience, has a huge influence on individual rationalisations of justice and right. Take the following, for example: "La conscience universelle, plus puissante que la police des rois et la sagesse des juristes, le dit [que le duel est juste]; et c'est parce que la conscience universelle le dit, que des règles sont imposées au duel, et que le meurtre commis par le duelliste est excusable." ${ }^{40}$ This example, taken from La Gueere et la Paix, is hugely significant since it shows, contrary to Ritter's analysis, that Proudhon understood the causal role of social norms in society. Clearly, this is but one example. Religion, law and other principles are also perhaps more obvious example of social norms determining social behaviour.

What Proudhon demands, therefore, is that all groups of individuals debate their interests, educate themselves, and fight for what they believe in. It is only thus that collective reason and forces can emerge from individual absolutes and change over time. In this regard, liberty, like force and individuality is disciplined by society prior to any other instrument. Complex social relations can only exist because of individual liberty and the deep anarchy, that is to say the sheer foundationlessness, of the social relations within which individuals are enmeshed. Proudhon's analysis suggests that it is the inherent diversity of individuality and the causal powers of distinct but porus collectivities in time

\footnotetext{
${ }^{37}$ Proudhon [1988/1990c], p. 1261.

${ }^{38}$ Proudhon [1988/1990a], p. 347.

39 Proudhon [1988/1990c], p. 1281.

${ }^{40}$ Proudhon [1998/1990a], pp. 223-224.
} 
and space, which explains the specific natures of different nations, towns, businesses, religions and so on. Furthermore, following Comte Proudhon argues that the larger and more intricate the organisation and the more coordinated the social power that results, the more "civilisé" it is. This says nothing of the justice of the system, nor can it tell us how societies came to be like this. I will now give a much more detailed account of Proudhon's theory of justice. The latter question of social change is dealt with in the following chapter.

\section{Justice and the Moral Organ}

As the opening epigram of the chapter indicates, Proudhon argued the following: philosophy is a practical activity necessary to science because it ensures its emancipatory potential. Using Comte's work he develops the idea of forces which he had been using from the beginning of his intellectual career, to understand the constitution of the collective aspects of social life. These are collective reason and collective force - the former ideational, the latter material. Both are irreducible to the individual but necessarily demand his or her active participation in order to constitute the collective. What I will do in this section is show the animus of this participation. Why is it people act in common to realise justice in the first place?

One of the key aspects of Proudhon's theory of justice that is overlooked by the majority of the secondary literature is what Proudhon calls "l'organe morale". ${ }^{41}$ This concept helps us cut through many of the competing debates about Proudhon's approach to Justice. Four things are central to this approach: the nature of the moral organ itself; Proudhon's use of the Kantian antinomy to explain the relationship between our conscience and our will; the resulting "immanence" of justice; and "droit de la force" in love, the family and marriage. This right of force is central to the analysis of right and war in La Guerre et la Paix, where he unites the sociological theory of the source of justice with a theory of the origin of the rights of peoples in world history. Of course, arguing for a right of force, particularly within the context of marriage should rightly make one feel uneasy. As I will show in the following chapter, Proudhon is also ambivalent about the role of rape in

\footnotetext{
${ }^{41}$ Proudhon [1988/1990d], p. 2057.
} 
warfare and his thinking derives from the assumptions I will present here. As I will show, since his theory of Justice underpins his entire philosophy, his international political theory is, like much else when seen from this perspective, tied intricately to his sexual politics. It is here therefore, that we are able to begin the positive and immanent critique of Proudhon's thought from a feminist perspective.

Given that I argue that the “moral organ” is central to Proudhon's thinking about justice, the most important section of De la Justice to bear on the source of justice takes place in the second book of “Amour et Marriage” in the $11^{\text {th }}$ Étude of De la Justice. Given his well-known sexism-verging-on-misogyny, the fact that it is here that we find the most important discussion of the source of morality may explain why so few, with perhaps the sole exception of Anthony Copley, ${ }^{42}$ have understood the centrality of Proudhon's sexual politics to his theory of justice.

As we saw in chapter three, the problem pre-Kantian classical metaphysics engaged with was the nature of "the thing in itself", which was itself shorthand for questioning both whether we can know if God exists, and also whether we can know God at all. Kant, as I have shown, despite turning the ontological question on its head, nevertheless managed to retain the necessity of the idea of God both philosophically and politically. Proudhon disagreed. If the thing in itself can never be known, since we cannot have direct knowledge of things (all things being mediated), and if we accept an inductivist approach to science God does not exist either, "sur quoi établir [...] la loi morale et l’ordre politique" ${ }^{43}$ This was the revolutionary question with which everyone struggled. Social and political justice had to be given some new non-theological foundation. The question was: where does Justice come from? Does it come from individual reason that ought to be applied universally à la Kant, or does it come from the state, society, the sovereign, or the findings of Priest Scientists and their legislation of political order? Kant, Proudhon argued, failed in this task.

\footnotetext{
${ }^{42}$ Copley [1989]. I discuss Copley’s ideas further below.

${ }^{43}$ Proudhon [1988/1990c], p. 1144.
} 
KANT [sic.] s'efforce de construire la morale, comme la géométrie et la logique, sur une conception a priori en dehors de tout empirisme, et ne réussit pas. Son principe fondamental, le commandement absolu, ou impératif catégorique, de la Justice, est un fait d'expérience, dont sa métaphysique est impuissante à donner l’interprétation. ${ }^{44}$

Proudhon cuts right to the heart of the Kantian edifice here. If reason is phenomenal and influenced by social forces, then it cannot be accounted for in terms of itself and the categorisation of the noumenal as beyond science is without foundation and opens up the possibility of a science of psychology. This also implies that Justice is no more reducible to “un rapport déclaré par la raison pure comme nécessaire à l'ordre social”45, than is it, pace Comte, “un commandement intimé par une autorité supérieure à un être inférieur”. Proudhon argued that "la justice est immanente à l'âme humaine; elle en est le fond, elle constitue sa puissance la plus haute et sa suprême dignité.”46

Thus the ultimate source of justice is our conscience, but the conscience is not a thing, it is a word. So what does it signify? Basic observations tell us that we know and often intuit the right thing when we feel it as good and the reverse as bad. Things generally smell bad when they are off, and better when their edible. ${ }^{47}$ But where does the moral feeling come from; how do we feel what is right? Proudhon argues that we have a "moral organ”.

Mais cette Justice, prétendue réelle, immanente, qui opère en nous à la manière d'une faculté positive, quelle est-elle, et comment agit-elle? Toute fonction, avons-nous observé à propos du libre arbitre, suppose un organe: où est l’organe de la Justice? On parle de la conscience; mais la conscience est un mot, le nom d'une faculté dont nous affirmons que la Justice est le

\footnotetext{
${ }^{44}$ Proudhon [1988/1990a], p, 309.

${ }^{45}$ Proudhon [1988/1990c], p. 1376 (emphasis added).

${ }^{46}$ Proudhon [1998a], 136.

${ }^{47}$ Proudhon [1988/1990c], p. 1373. Cf. Wright [1999], Hauser [2006]. Interestingly, Proudhon criticises the approach to evolution that understood it as a fatalistic trap of development within an individual creature for example, the eternal return from larva to butterfly. See the second chapter of the $9^{\text {th }}$ Étude, Progrès et Décadence, titled “Critique de l’idée de progrès (suite). - Théorie de l'évolution”, Ibid. pp, 1555-1571.
} 
contenu, et qu'il s'agit de montrer à cette heure dans son organe même... de même que Rien ne se produit de rien, Rien ne fonctionne à l'aide de rien; cet axiome peut être ajouté aux autres, et s'appeler PRINCIPE D’INSTRUMENTALITÉ: la vue, l'ouïe [...etc] ont chacun leur organisme [...] qui est le cerveau; et dans ce cerveau chacune des facultés de la pensée a son petit appareil, comment la Justice, faculté souveraine, n’aurait-elle pas son organisme, proportionné à l'importance de sa fonction? ${ }^{48}$

This, as Comte argued before him, is tantamount to a biological theory of morality and should not surprise us. Proudhon believes that the whole body is a moral organ precisely because he agreed with Comte that it was no longer adequate to talk of justice in rationalist terms. It is not right to put someone's hand in the fire because we know it hurts. It is not the reason, but the pain which prohibits torture and empathy the feeling which propels us to criticise it.

For Proudhon and Comte, biology had proven that morality was far more complex than the rationalists would have us believe. But vitally, and contrary to Comte, if the body is the source of justice then it ought to be protected and respected, and the personalities and bodies of others no less so. If we are the source of justice, if moral dignity is the basis of empathy and respect, then no one has the transcendent right to repress us and nor do we have the right to repress others. It is in this context that we ought to understand Proudhon's argument that justice is reciprocal respect for the moral autonomy of another based on the recognition of one's own moral autonomy and a sense of self-respect. As he put it:

le droit est pour chacun la faculté d'exiger des autres le respect de la dignité humaine dans sa personne; - le devoir, l'obligation pour chacun de respecter cette dignité en autri. Au fond, droit et devoir sont termes identiques, puisqu'ils sont toujours l'expression du respect exigible ou dû. ${ }^{49}$

\footnotetext{
${ }^{48}$ Proudhon [1988/1990d], p. 2057.

${ }^{49}$ Proudhon [1988/1990a], pp. 299-300. Bearing this quote in mind we can also see how Vincent [1984] easily located Proudhon within the French republican tradition. Cf. Vernon [1986].
} 
This social contextualisation of the moral faculty is a natural extension of Proudhon's broader social ontology and its emergence from individuals. However, as discussed in Chapter two, it was common for liberal theories to see the individual as inviolable and that the clash between these inviolable wills led inevitably to social conflict. The assumption of conflict derived from a fixed and transcendent conception of human needs, and a drive to secure physical survival in anarchy. But this is an unnecessarily restrictive political theory and social ontology. Self-preservation is but one of many natural human actions. Thus understanding how societies form demands a far broader conception of human motivation and social context. Proudhon provides a new twist on the state of nature theory to explain his position:

D’après cette théorie, l'homme, quoique parti d’une sauvagerie complète, produit incessamment, par le développement spontané de sa nature, la société. Ce n'est que par l'abstraction qu'il peut être considéré à l'état d'isolement et sans autre loi que l'égoïsme. Sa conscience n'est pas double, comme l'enseignent les transcendentalistes; elle ne relève point, pour une part, de l’animalité, et pour l'autre, de Dieu; elle n’est que polarisée. Partie intégrante d'une existence collectif, l'homme sent sa dignité tout à la fois en lui-même et en autri, et porte ainsi dans son coeur le principe d’une moralité supérieure à son individu. Et ce principe, il ne le reçoit pas d'ailleurs; il lui est intime, immanent. Il constitue son essence, l’essence de la société elle-même. ${ }^{50}$

This is far more nuanced, I believe, than traditional Hobbesian or Rousseauean approaches, and because Proudhon sees morality as irreducible, historical and thus socially contextualised, it is also far more emancipatory than the liberal theory. Because it respects the individual according to well-known liberal principles, it is also antiCommunist and/or Comtean. Crucially, because it is based on a humanist ontology, it is also far more philosophically realist and intuitively realistic than those of his contemporaries. Proudhon recognises this tension between the social and the individual and, rather than 'resolve' it by abrogating the individual's moral autonomy or denouncing all collectivities as oppressive, he argues that this tension is in fact historically and

\footnotetext{
${ }^{50}$ Ibid., p. 177.
} 
morally productive. The tension between the social right and the instinctive right has to be worked through rationally and there are no transcendental resolution to this problem simply because we are humans and our lot is to muddle through.

\section{The Antinomy}

As I discussed in Chapter three, Kant argued that the antinomies of pure reason were in perpetual and irresolvable conflict and were a block to the fantasies of pure solipsism, and reason's reach beyond the confines of the rational. The transcendental dialectic was also the way in which Kant let God back into his analysis. As such, the antinomies of pure reason direct our mind to the empirical realm, to what is rationally verifiable before they thwart our attempts to create synthetic a prioris beyond the limits of reason. Proudhon understood the antinomy in quite different terms but took Kant as his inspiration. In a letter to Tissot, Kant's principal French translator at that time, Proudhon stated that "[i]n reading Kant's antinomies, I saw in them, not a proof of the weakness of our reason, nor an example of dialectical subtlety, but a veritable law of nature and of thought." ${ }^{51}$ In his early works this "law of nature and of thought" is rather confusing. Proudhon's first statement of his theory comes in the System of Economic Contradictions where he famously vacillated between a Kantian and a Hegelian formulation of the dialectic and invited much ridicule for it from Marx. However, in De la Justice Proudhon corrects his earlier position by arguing that,

L’ANTINOMIE NE SE RÉSOUT PAS; là est le vice fondamental de toute la philosophie hégélienne. Les deux termes dont elle se compose se BALANCENT, soit entre eux, soit avec d'autres termes antinomiques: ce qui conduit au résultat cherché. Une balance n’est point une synthèse telle que l'entendait Hegel et que je l'avais supposé après lui: cette réserve faite, dans un intérêt de pure logique, je maintiens tout ce que j'ai dit dans mes Contradictions. $^{52}$

\footnotetext{
${ }^{51}$ Cited in De Lubac [1948], p. 144.

${ }^{52}$ Proudhon [1988/1990b], p. 567.
} 
What he argues is that the two poles of the antinomy are held in an antagonistic balance good vs. evil for example, or cause and effect, infinity and finitude, and so on. These antinomies also balance amongst themselves: perhaps the antinomy between good and evil also balancing against the antinomy between necessity and free will for example. Proudhon sees this principle of balancing replicated in mathematics where equations must balance; in law where rights must be balanced; in political economy where balance sheets are de rigueur, and almost anywhere else one would care to look. Understanding the forces that hold these poles in equilibrium is the purpose of science, no less in the moral than in the physical realm. It is only when the poles are in harmony that it can be said that order exists, but this is only ever contingent and takes place in distinct social and historical periods.

When we add the concepts of "collective force" and "collective reason" the forces that affect (the terms of) this balancing are revealed. Capitalism, the discovery of gunpowder, the fight against theological cosmology, and so on, all disrupt conventional or historical social equilibriums and cause them to re-calibrate while accommodating new collective forces and rationalities. As we will see in the following chapter, and as I alluded to in chapters one and two, Proudhon was quite aware of the role of material forces in disrupting or changing this equilibrium. However, his conception of justice also allows us to see how individual rationalisations of the world, no less than our gut instinct, also shape the way we act in it, help us re-rationalise any changes we might bring about, and subsequently seek to counter. Justice is the temporary equilibrium that emerges from this general social conflict. We do not find the key motors of this process outlined in any detail in this work. His philosophy of history is spelt out in far more detail in the works that followed.

Proudhon's aim in each of the twelve études is to use this dynamic theory of change and his humanist theory of justice to combat ecclesiastical, metaphysical and scientific claims to "nécessité". For example, the first étude turns to the problem of justice and shows that for the church justice is a matter of revelation and dogma and thus unchanging. For metaphysics it is a transcendentally deducible "notion de l'entendement". Proudhon claims that for justice to have compelling meaning, for it to fulfil the promise of the 
revolution it must be real, which is to say changing and social and civic, but also based in the conscience. In the second étude, titled "Les Personnes", Proudhon argued that religion served as the primitive moral compass where the conception of original sin allowed humans (or perhaps more modestly, early Christians) to think through this universal condemnation. The system of the revolution, on the other hand, "est celui de l'IMMANENCE, ou de l'innéité de la Justice dans la conscience.”33 This concept of immanence is used as a critique of the fatality of religious dogma when it comes to material well-being. Proudhon suggests the revolution presents society with a new principle of social equilibrium based on the idea of equality and reciprocity.

The fourth étude turns to the state where, arguing against divine right and popular sovereignty ("son equivalent"), he argues that the doctrine of the necessity of overarching authority inherent in both are spurious. Arguing against the providential character of modern political justifications for the state, Proudhon looks back to earlier revolts against providential power in the classical slave revolts and elsewhere, which signify not an eternal or potentially transcendental order, but one that changes and evolves because of an innate drive to resist despotism or to express our individual and collective autonomy. This modern age of individual rights, consecrating the will of the individual as autonomous, was the great breakthrough of the Revolution, but Proudhon sees clearly its own providential and millenarian character and strikes against it as I illustrated in chapter one. The same formulation is worked out in the following eight études but space restricts my analysis of them here. Nevertheless, the defining concept Proudhon brings to this discussion is that of immanence. It is to this concept that we will now turn.

\section{Immanence}

In chapter four of the first étude of De la Justice Proudhon discusses the "Réalisme de la Justice - La Transcendance et l'Immanence". ${ }^{4}$ This is a distinction he makes between different conceptions of the source of justice in human affairs. As mentioned briefly above transcendence is comparable to the system of revelation for Proudhon which is to

\footnotetext{
53 Proudhon [1988/1990a], p. 177.

${ }^{54}$ Proudhon [1988/1990a], p. 167.
} 
say that for both modern philosophy and religious dogma, justice comes to us from 'elsewhere', it is “surhumaine” and needs a God to confer legitimacy upon it. It is for this reason that "Jean-Jacques Rousseau, Kant, Spinoza lui-même [...] tous les éclectiques, les spiritualistes, les socialistes, les panthéistes, jusqu’à Auguste Comte, qui en niant Dieu se raccroche au grand Etre humanitaire, ne parle pas autrement." ${ }^{55}$ Clearly, Proudhon is engaging in serious debates here. The casualness with which he does so signifies perhaps two things: a broader familiarity with the debates and secondly, his task of popularising their terms in such a way as to make them intelligible to a wider public.

What he argued was that his own theory of immanent justice allows us to see justice as historically evolving and socially contextual, but also inextricably linked to a basic universal human nature (definitions which will change with human scientific selfawareness). Therefore, if justice is immanent there can only be socially and personally acceptable compromises to matters of right and wrong. Proudhon argued the following:

Nous savons discerner le bien du mal; nous ne saurons jamais la fin du Droit, parce que nous ne cesserons jamais de créer entre nous de nouveaux rapports. Nous sommes nés perfectibles; nous ne serons jamais parfaits: la perfection, l’immobilité, serait la mort. ${ }^{56}$

Stamping his own mark on this concept, Proudhon argues later in the work that he who speaks “comme un partisan de l'immanence [est] un vrai anarchiste."57 Again, the motors of this immanence will be discussed in more detail in the chapter to follow. What we need to see first is how, following Kant and Comte and their lengthy discussions of the role of women in society, Proudhon sets out the familial root of the social instinct and thus the social root of justice and of politics.

\footnotetext{
${ }^{55}$ Ibid., p. 172. The attempt of the Saint-Simonians to found a civic religion is discussed at length in pages 248-257.

${ }^{56}$ Ibid., p. 183.

${ }^{57}$ Ibid., p. 637.
} 


\section{Love, Women, the Family and Marriage}

There are three more analytical reasons for taking this discussion of Proudhon's theory of justice into the area of sexual politics. The first is that with a full understanding of Proudhon's theory of justice we can deepen and/or explain problems in other analyses of Proudhon's work. Proudhon's anti-feminism and his sexual politics have been widely misunderstood and in instances where they are better understood, the full implications are not taken to their logical conclusion. To illustrate this latter point I will use the work of Anthony Copley. ${ }^{58}$ Secondly, by linking the discussion of justice to the concepts of love, marriage and the family we can better account for Proudhon's anti-feminism and subject it to a better immanent critique (using Proudhon's own concepts against his theory). And thirdly, we can understand the centrality of the "right of force", the key concept of the following chapter, to his later writings on international politics.

Of all the interpretations of Proudhon's sexual politics I think Anthony Copley's is the fairest and best. He argues that Proudhon's sexual politics are not an afterthought to his moral philosophy, nor are they utterly irreconcilable to his broader thinking, nor should we see them as superfluous to his thinking about war and peace. Proudhon's sexual politics are absolutely vital to our comprehension of his metaphysics, and his androcentric theory of world politics, just as it ought to be with all his contemporaries and predecessors and a number of our own. Androcentrism does not automatically disqualify Proudhon as a thinker, nor does his eurocentrism. The key is to be able to account for the work they do in his theory and explain their inevitable weaknesses. If Proudhon's biases can be corrected using his own theory, so much the better.

We need to see Proudhon's conception of the family as rural reaction to urban and bourgeois conceptions of marriage. Segalen's discussion of sexual and domestic relations within the peasant family provides much needed context in this regard. ${ }^{59}$ In her analysis, women had asymmetric equality in peasant families based on their predominance in domestic life, their care of children, the garden and food. Segalen shows that men were

\footnotetext{
${ }^{58}$ Copley [1989].

${ }^{59}$ Segalen [1983].
} 
traditionally supposed to play a social authority role as head of the family and as an authority figure in village life. This was the sociological basis of cohesion in the peasant community. This division of authority was arguably extant in Proudhon's own family where his mother, whom he adored and who was from a peasant background, was the dominant force in his own parents' relationship. ${ }^{60}$ But his father's lack of business acumen and fortitude consistently put the family in economic difficulty exacerbating his mother's workload. Copley suggests that Proudhon's stern moralism is a reaction to his father's idealism, and also argues that his (perhaps oedipal) love for his mother may account for Guérin's (perhaps inaccurate?) assertion of Proudhon's repressed homosexuality. ${ }^{61}$ As we will see in the following chapter, Proudhon places huge emphasis on work, and resigns women to a domestic role assuming the two to be asymmetrically equal.

Proudhon also argued that the first and most important locus of collective force is the family. It is the primordial unit of society and the father is, for him, the natural leader and the first to appropriate social "puissance”, ${ }^{62}$ While in Proudhon's view men are rightfully the head of the family, this primal appropriation is nevertheless unjustified where it is not balanced by other familial obligations. ${ }^{63}$ Proudhon understood patriarchy as a "law of nature", where "la force plus grande absorbe et s'assimile les forces plus petites, et que la puissance domestique devienne un titre à la puissance politique: aussi n’y a-t-il de compétition pour la couronne que parmi les forts." ${ }^{64}$ In the event, Proudhon massively underestimates the negative effects and the extent of patriarchy within families and society at large. D’Héricourt's critique of Proudhon is instructive here. As she put it:

You wish to subordinate women because in general they have less muscular force than you; but at this rate the weak men ought not to be the equals of the strong, and you combat this consequence yourself in your first "Memoir on

\footnotetext{
${ }^{60}$ See Woodcock [1956] for the best analysis of Proudhon's relationship to his parents.

${ }^{61}$ Copley [1989].

${ }^{62}$ Cf. Bouglé [1911], p. 225-229.

63 Proudhon [1988/1990b], p. 706.

${ }^{64}$ Ibid.
} 
Property" where you say: "Social equilibrium is the equalization of the strong and the weak."65

Proudhon's position was that this equalisation would be asymmetrical and because of the terms of this asymmetry it is necessarily sexist. His conservative views of the place of women in the family were themselves culturally and historically derived rather than based on any objective logic. As D’Héricourt puts it: "You have naively mistaken the scalpel of your imagination for that of science.”66

Putting this critique to one side for a moment, for Proudhon marriage is the lynchpin of the social fabric (and of his theory of justice) because it stipulates and consecrates - by commutative contract - (what is in reality a dis)equilibrium between the sexes within the family unit. Strangely, in the case of sexual relations, this equilibrium is not obviously immanent and open to change since Proudhon stipulated that women will always be inferior to men. But marriage, Proudhon argued, makes up for this. For Proudhon marriage is emancipatory for men in that it releases them domestic drudgery and allows them to pursue their civic roles. Women, on the other hand, simply have men protect and support them and release them from the social stigma of solitude. Proudhon argues that the antinomy between male and female should thus be seen to be emancipatory, though we might rightly disagree precisely because, in this instance, Proudhon is not nearly consistent enough.

In order to explain what is going on here Copley focuses on the idea of the androgynous marriage unit, or "the couple, as the relationship within which justice would evolve." This was not the effacement of sexuality in Proudhon's thinking, since sexual difference is the prerequisite of the union, but a new and irreducible unity. But I believe there is a better way of understanding Proudhon's sexism and one which is closer to Proudhon's metaphysics rather than his politics in this instance.

\footnotetext{
${ }^{65}$ D’Héricourt [1981], p. 45.

${ }^{66}$ ibid., p. 58.

${ }^{67}$ Copley, [1989], p. 215.
} 
Close readings of Proudhon's work on love and marriage, particularly within the context of his peasant background, illustrate that emancipated female sexuality "frightened" Proudhon, not only because of the full expression of sexuality this implied, but also because of the damage he thought it would wreak on the family. ${ }^{68}$ The Utopians advocated free love and the dissolution of the family as the basic social unit, arguing that bourgeois marriage was legal concubinage. But this was clearly not Proudhon's own experience, nor as Segalen has shown, did it extend far beyond urban, and middle and upper class limits. Moreover, Proudhon’s Catholic background led him to see pre-marital chastity as the lynchpin of Platonic virtue. As Copley has remarked, "Proudhon declared war on the morality of the Church [abstinence] in the name of what he believed to be his own higher sexual morality of chastity."69 Infatuation and lust, infidelity and the primal impulses are human, he argues, but they all ought to be tempered because they do not last. A deeper love, he argues, combines this instinct with human social relations and the zenith of this is the unity of marriage. Widespread prostitution combined with a fear that emancipated women would simply turn to prostitution, blinded Proudhon to the observation that D'Herricourt made that marriage was a form of prostitution when women were given no rights at all, and within marriage were actually considered male property. $^{70}$

The antinomy between the sexes is historically contingent and Proudhon's response and formulation of it no less so. We cannot divorce this context from his theory since, as Copley has argued, "Proudhon was as much at war with the French tradition of male sexual dalliance as with the feminist quest for sexual emancipation." ${ }^{\text {,1 }}$ Proudhon was well aware, and as I discussed in the previous chapter, that it was women who paid the price for male promiscuity in nineteenth-century France, and the Church was all too willing to exploit rejected women and the social and moral conflict widespread prostitution created, for support. Proudhon also believed, incorrectly but somewhat conventionally for his time, that women were mere receptacles for male semen and thus

\footnotetext{
${ }^{68}$ Ibid., p. 208.

${ }^{69}$ Ibid., p. 200. Proudhon was annoyed at Fourier's "praise of perversions” and claimed, according to Copley, that “Utopian socialism ... led ineluctably to pederasty.” Ibid., p. 207.

${ }^{70}$ D’Héricourt [1981], p. 41.

${ }^{71}$ Copley [1989], p. 212.
} 
lacking any autonomous role in sexual relations (ignoring the rather longer period of gestation as men are wont to do). Copely has argued that,

It was misunderstandings such as these that led Proudhon into that absurdity of enumerating male superiority over female by a factor of twenty-seven to eight. From the male seed, he claimed, women derived ideas, conscience, even consciousness: such dependency was his explanation for female inequality [...] Such mistaken theories led Proudhon to see in marriage the only hope for women. ${ }^{72}$

One might argue that Copely has this back to front. Proudhon did not misunderstand these issues, as Haubtmann has argued, he wilfully ignored the evidence. ${ }^{73}$ Moreover, it was his principles and ideas that drove his theory here, rather than vice versa. Proudhon may have a point about force being at the heart of social order as I will discuss further. However, it is vital to criticise his patriarchy as the justification for this force and show it to be based on sexism.

Proudhon outlines this theory of the innateness of morality in the eleventh étude of De la Justice on "Les Femmes". Here he argues that an inalienable right to exercise our conscience speaks to our innate sense of Justice. What this means is that exercising our conscience is acting purposefully in the world. This he called our innate "right of force". This ought to be kept separate from any conception of power and ought to be thought of as the right to purposive action or inert resistance of one body on another. ${ }^{74}$ In the first additional note to this étude Proudhon writes that

Dans un ouvrage qui paraîtra prochainement, nous exposerons la théorie de ce droit, de ses formes, de ses applications, de ses abus. Elle jette sur l'histoire de la formation et du développement des Etats un jour inattendu, qui rejaillit

\footnotetext{
72 Ibid., p. 213.

${ }^{73}$ Haubtmann [1988b], p. 67. Haubtmann even notes that Proudhon even annotated the most recent works which proved the moral and biological equality of the sexes but ignored their conclusions.

${ }^{74}$ Proudhon [1988/1990d], p. 1949.
} 
sur la constitution du mariage et de la famille, aussi peu comprise encore que celle de l'Etat. ${ }^{75}$

It is quite stunning to see Proudhon refer to his La Guerre et la Paix in such a way, particularly in this work on women and marriage. It becomes less surprising when we understand the role sexual relations play in his understanding of virtue. But given this argument might one argue that if women assert their own force, not necessarily muscular as Proudhon prioritises here, but in whichever way women chose, and we understand the relationship between the sexes as antinomic and thus productive, and we see the family as a microcosm of social relations; ought we not also, then, be able to see that this conflict of the sexes is as productive as every other relationship? With a fuller understanding of the natural equality of the sexes, the foundationlessness of Proudhon's pseudo-science and ignorance can be recognised, and his fear and well-meaning paternalism can be rejected. Moreover, it is precisely because Proudhon's sexism has complex social and ideational roots that we can develop this critique using Proudhon's own theory of immanence and collective reason. Proudhon's attitudes are worth explaining because they illustrate how his theory works and how the theory might be used to correct his own prejudices by showing their historical and cultural (as opposed to natural and inevitable) roots.

Proudhon ought to have seen the systems of collective reason that were shaping his views, and the collective forces underpinning unequal marriages. He ought to have suggested ways of overcoming the unnatural equilibrium women found themselves in and he ought to have done so publicly. Proudhon should also have seen (if he was to be consistent with his own theory) that female self-governance, based on economic and political emancipation, was central to an equitable equilibrium between the sexes. The absence of this equality is the root cause of the social conflict produced by unequal legislation. Proudhon had no consistent theoretical and normative grounds to resist this argument since it is his own. One can only conclude that he made an exception in this instance and did so consciously. This analysis of sexual hierarchy, while not Proudhon's,

\footnotetext{
${ }^{75}$ Proudhon [1988/1990d], p. 2117. In the notes to the eighth Étude on conscience and liberty, Proudhon makes another allusion to La Guerre et la Paix and links the subject directly to the foundations of democracy. Proudhon [1988/1990c], p. 1515.
} 
nevertheless leads directly to the second instruction of the Petit Catéchisme. What we need to know is how Proudhon thought collective force was appropriated and how collective reason is manipulated or becomes enlightened. Whatever the answer, this is an analysis he chose not to apply consistently to sexual relations.

\section{"Instruction II: On the Appropriation of Collective Force and the Corruption of Social Power”}

As Proudhon asks at the outset of the second instruction, "Comment la force collective, phénomène ontologique, mécanique, industriel, deviant-elle puissance politique?"76 To answer this question, he turns to the new science of political economy and criticises Comte for ignoring the implications of a socialist political economy for his positivist religion and for ignoring economics in his sociology. What we will see here is how a conception of collective force, understood from a socialist perspective becomes Proudhon's "ontologie révolutionaire", ${ }^{77}$ and we can now also disagree with De Lubac's otherwise excellent analysis when he argues that Proudhon "had an instinctive aversion for all kind of system and for all ontology."78

Proudhon argues that all groups and individuals stand in political relations with one another once their actions are motivated and purposeful. All social life is thus potentially political (with the exception of sexual relations). What Proudhon wanted to do was understand the rules and codes of moral and social behaviour that regulate and sustain political and economic society. The internal relations of societies are regulated through conscious or subconscious codes of behaviour, but societies are also regulated by their internal collective forces, which in turn differentiate them from one another. Different industrial and economic groups, ranging from the family to the productive capacities of factories and nations, are constituted in terms of the organisation of the collective forces which define them, the norms of justice which emerge from them and subsequently help regulate their interrelationship. Contrary to Comte's formulation, it is important to note

${ }^{76}$ Proudhon [1988/1990b], p. 694.

${ }^{77}$ Ibid., p. 725; cf. Wight [2006].

${ }^{78}$ De Lubac, [1948, p. 141. 
that there is no centre to this system. Indeed, in a phrase taken from Pascal, Proudhon argues that "in my system the centre is everywhere, the circumference nowhere. This is unity."79

Turning to capitalist society, Proudhon saw that collective force was expropriated and monopolised through the institution of private property which gives title holders state protection for their expropriation and sanctifies their monopoly of title to the output of collective force in return for taxes. Taxation or expropriation is necessary for a collectivity that produces nothing of its own, and for Proudhon we ought thus to understand the state and capitalism (though not patriarchy) parasitically. ${ }^{80}$ The twin forces of state and capital place objective and contradictory pressures on social relations. The ensuing dis-equilibrium is sustained by the states preponderance of material force. In different historical periods “[1]a qualité du pouvoir social varie, son intensité s’élève ou s’abaisse, selon le nombre et la différence des groupes: quant à l'unité, elle reste immuable." ${ }^{81}$ Thus we ought to understand the potential powers of different collective forces within a wider context.

Collective reason emerges to justify or criticise this state of affairs, adding further layers of complexity. Proudhon, reverting to Comte again, begins with an analysis of the conflict between monotheism and polytheism and the collective forces the two rationalised; then he analyses metaphysics and the shift in social power it drove and described; and finally he turns to science and the way in which it understood, drove and rationalised the industrial revolution and all that followed. At each point in time the underlying constants in the human imperative to consume and the social imperatives to collaborate to secure human existence remained constant, while the rationalisations given of the particular social orders in which these imperatives manifested changed. Thus, there has always been exploitation and people have always been segregated; it is the types of rationalisation we use that varies and this is related to education, the development of science and intelligence and dramatic changes in our material environment. Of course, for Proudhon it is only in the third scientific stage that these collective forces that structure

\footnotetext{
${ }^{79}$ Vincent [1989], p. 215.

${ }^{80}$ cf. Tilly [1985].

${ }^{81}$ Proudhon [1988/1990b], p. 700.
} 
human action can be understood for what they actually are, rather than what they are believed to be. In this regard, the purpose of the second 'Instruction' of the catechism is to outline how it is that a phenomenon as considerable as "collective force", "qui change la face de l'ontologie", 82 can be hidden from philosophers for so long.

The first reason is that collective force is deliberately appropriated by the dominant powers in society. The subsequent “corruption” of those very same powers results from or, “en termes moins sévères, une économie arbitraire et une constitution artificielle de la puissance publique." 83 This artificiality is historically derived from monopoly which is to say from the domination of one power over the inherent plurality of collective forces thus reality is hidden while an arbitrary alternative enforced. The second means by which this process has become clouded is through natural human deference. Proudhon also argues that the adoration of the father is the first of many variations on social and political deference and in his view probably the most important because it is the one form which all individuals have to endure or willingly accede to in infancy and beyond for our very survival (ignoring the role of mothers again). He argues that by this deference the individual becomes immersed in the social and cannot leave it for fear of "tomber dans le néant.” Third, the ideals of religion, government or particular types of scientific doctrine, and the orders and power they sustain, hold societies together through their ability to provide rationalisations for complex social hierarchy, provide outlets for social deference, and thus cloud our ability to see the actual origins of social change - human collective force. Social acceptance of the doctrines of God and religion, then the State, Nation and the General Will are unconscious or tacit genuflections to dominant rationalisations of social power designed both to explain and to legitimate the balance of power within society. The individual and collective "alienation" 84 of this collective reason takes the form of personification, which we will discuss further in the following chapter, and "anthorpomorphisme” which is then confused with an actual reality.

Thus the inevitable contradictions in society that are caused by this political and economic expropriation, an expropriation Proudhon ignores in the family, necessitate

\footnotetext{
${ }^{82}$ Proudhon [1988/1990b], p. 705.

${ }^{83}$ Ibid., p. 706.

${ }^{84}$ Ibid., p. 709.
} 
state power and necessitate ideologies to rationalise it, otherwise they could not endure nor could we explain how ideas can shatter these certainties and the material orders they support. Paradoxically, expropriation and alienation of collective force and reason are "la négation de l'ordre" because of the imbalances that are knowingly or unknowingly perpetuated. This also implies something far deeper for Proudhon: "En principe, la société est ingouvernable; elle n’obéit qu’à la Justice, à peine de mort.”85 It is therefore, "votre première loi [...] de garder votre âme et de ne vous incliner devant aucune divinité, ni du ciel, ni de la terre, ni de l'enfer.",66

Needless to say, this is as applicable to familial relations as to the wider social relations that sit atop them. With the work of women appropriated for the benefit of patriarchal order, justice cannot be said to exist. Proudhon ought to have seen how his own discourse of family life performed the same function. I will discuss his wife's role in the family during the writing of his theory of international relations in the following chapter, as a symptom of a broader structure of social relations. However, the basic elements of my critique ought to be clear from the above discussion.

\section{"Instruction III: Forms of Government and their evolution during the Pagano-Christian era”}

The third, fourth and fifth instructions are of less heuristic and intellectual value for this chapter since many of the themes are developed substantially in the texts which followed De la Justice and are thus more likely to make sense in the context of the following chapter. Nevertheless, for the sake of comprehensiveness, I will say a few words about them. What he provides here are simple explanations of the types of collective reason and forces that went to make up past societies and the key principles that held them in their temporary, immanent equilibrium.

Proudhon argues here that pre-Roman social orders were constituted on principles which were in conflict with the actual nature of society because they simply did not understand

\footnotetext{
${ }^{85}$ Ibid., p. 712.

${ }^{86}$ Ibid., p. 326.
} 
it correctly - nor could they have been expected to. With the individuals who comprised these societies believing society to be governed, not by its own animating forces, but by the hand of God, these orders were inherently unstable and demanded the utmost care in pacifying the celestial power. In the pre-scientific era, Proudhon argues, instability was caused by the following: inequality enforced and consecrated by the incorrect divination of the forces governing society; the appropriation of collective forces; substitution of a spurious for a factual power; “Abolition de la Justice par la raison d'Etat”. ${ }^{87}$ Thus the future is abandoned to Divine Providence and the whim of the state. Crisis is periodical and society continually prone to collapse or revolution.

'What is to be done?' he asks. In his view the key is to reorganise the economic equilibrium in society. This argument is expanded at length here and I will return to his more detailed mutualist solution in chapter six. But briefly, this involves returning the preponderance of power in this domain to the people who produce it and this is not reducible to class, but ought to be returned to the myriad collective forces in society and ultimately the individual. Political order, following Montesquieu, ought to be organised according to topography, climate, and "l’importance relative des éléments constituents, servant à marquer en chaque pays le centre de gravité politique." ${ }^{88}$ The goal is the millenarian "paix perpétuelle" but this is currently impossible because "toute nation en qui la balance économique est violée, les forces de production constituées en monopole, et le pouvoir public livré à la discrétion des exploitants, est, ipso facto, une nation en guerre avec le reste du genre humain.”,89

\footnotetext{
${ }^{87}$ In the first appendix to Book 4, “L'Etat”, Proudhon discusses the issue of raison d'état at length. Proudhon [1988/1990c], pp. 743-752.

${ }^{88}$ Ibid., p. 718.

${ }^{89}$ Ibid., p. 719.
} 


\section{Instruction IV: The Constitution of Social Power by the Revolution”}

The fourth instruction turns to the subject of the revolutionary era and its promises for collective force. Is it, Proudhon asks, a better expression of the reality of social power and collective force? His answer has two parts. First, the Old Order had only ever understood social power nominally, as a concept rather than a reality. This is related to the nature of the force which the Old Order believes to govern society - God. The revolutionary ideas of Rousseau were no less religious.

En face du droit divin, la Révolution pose donc la souveraineté du peuple, l'unité et l'indivisibilité de la République. Mots vides de sens, propres seulement à servir de masque à la plus effroyable tyrannie, et tôt ou tard démentis par l'événement, s’ils ne séparent à l’organisme supérieur, formé par le rapport des groupes industriels, et à la puissance commutative qui en résulte. ${ }^{90}$

The political consciousness of the revolutionaries was scarred by the memory of the Terror, the failings of 1848 and the ensuing coup d'état. The aim of the revolution ought to be to affirm collective force and reason in all its myriad and contradictory natures, as opposed to trying to fallaciously create a homogenous social mass of the type advocated by Rousseau and Comte in the interests of either historical or divine providence. These real collective forces ought to be consecrated in law to give legitimacy to workshops, to the atelier and collective farms that made up the vast majority of the French economy. Collective property ought thus to balance individual capital, and as many have shown, for Proudhon small scale possession and collective title was a bulwark against large scale capital. ${ }^{91}$ We will have occasion to discuss the matter of economic democracy and the

\footnotetext{
${ }^{90}$ Ibid. p, 724 (emphasis added).

${ }^{91}$ In the conclusion to his work on the contemporary intellectual property rights regime, Chris May advocates a Proudhonist conception of property as a bulwark against global capital. See, May [2000], p. 181.
} 
normative project that underpins it in chapter six, here I simply want to flag up the consistency in Proudhon's thought.

\section{"Instruction V: Issues of the Day"}

The interesting thing about the fifth Instruction is that it puts into practice what Proudhon was preaching by using theory to engage with the political and economic problems of his day. Here he engages with the Imperial state of Napoleon III. Many of the themes of this part were covered in detail in chapter one. However, here he adds that dictatorship is either tyranny or useless; universal suffrage on the other hand is a waste of time when solicited in mass constituencies. Neither Proudhon nor Napoleon III it seems, thought the people could be trusted to turn in results that would be acceptable to either the ruling elites or their challengers. For Proudhon, however, the solution was to argue against the whole system - for Napoleon it was to control it. Proudhon argued that,

Pour rendre le suffrage universel intelligent, moral, démocratique, il faut, après avoir organisé la balance des services et assuré, par la libre discussion, l’indépendence des suffrages, faire voter les citoyens par catégories de fonctions, conformément au principe de la force collective qui fait la base de la société et de l'Etat. ${ }^{92}$

Since he expands this idea at length in his Du Principe Fédératif (1863) and De la Capacité Politique des Classes Ouvrières (1865), I will not discuss this in any detail here. Suffice to mention that what we have here is a radical reconstruction and re-legitimating of alternative political cleavages in society. Proudhon's ontology is radically pluralist, seeing difference and asymmetric unity as constitutive of political force. The objective had to be to find a way of harnessing this force and organising it in such a way as to ensure that society remained stable. Proudhon also believed his project ought to be universalised. "Il est très simple" he said ; "[l]a Révolution doit faire le tour du monde; les peuples sont fonctions les uns des autres, de même que, dans l'Etat, les groupes

\footnotetext{
92 Proudhon [1988/1990b], p. 734.
} 
industriels et les individus. Tant que l'équilibre ne sera fait sur le globe, la Révolution pourra se croire en danger." ${ }^{\text {93 }}$ How this ought to look is the focus of chapter six, but Proudhon here argues that the solution is simple and typically Kantian, Rouseauean and republican: “[c]’est le fédéralisme universel, garantie suprême de toute liberté et de tout droit, et qui doit, sans soldats ni prêtres, remplacer la société chrétienne et féodale.”94 Federalism, he argues, is "la forme politique de l'humanité" 95 and within this it is Voltaire's popular Candide which provides Proudhon's inspiration for the garden utopia he envisages.

\section{Conclusion: Justice as Immanent Equilibrium}

As Proudhon argued, “le moraliste n’a qu’un but, c’est de pénétrer la raison des coutumes et des institutions." ${ }^{\prime 96}$ As such, providing the encyclopaedic documentation of the evolved norms of French society, as Proudhon does here, is testament to both his sociological credentials and to his credentials as our first truly secular moralist. Proudhon set out what he thought were the principles of right moral action, not from the deductive coherence of abstract theories, but from the natural limits which society and our natures impose on us, how we might change them, and how, by knowing ourselves and the reality of social forces a little better, we might have better grounds for legitimating our evolving demands.

Proudhon's theory might be neatly summarised as the following: justice is immanent equilibrium, an equilibrium that changes and becomes re-calibrated as our understanding of the world changes. As our material and intellectual capabilities to change the world become more highly developed and more of our potential is emancipated, society will change also. When the antinomic poles within social relations (such as between rich and poor, male and female and so on), or within the individual (between reason and emotion, chastity and lasciviousness), sustain their harmony automatically as opposed to by force (material or ideational), then justice can be said to exist. In this sense, Proudhon is not as

\footnotetext{
93 Ibid., p. 734.

${ }^{94}$ Ibid., p. 735.

95 Ibid., p. 736

${ }^{96}$ Proudhon [1988/1990c], p. 1986.
} 
far from Kant as we might assume, but he is clear that this would not make us "bees or beavers" because this system will not hold transcendentally as I will show in the following two chapters.

The remaining question is: how does change occur? How, for example, does order become constituted within social relations, or do social relations break down? What are the main motors of change? How does society change from one form of collective reason to another? How or why do collective forces change their internal make-up, become abandoned or championed? How should it be in the future? What about law? These questions and many others will be addressed in the following two chapters. It is to the 2000 pages that form what is effectively an appendix to the ninth étude of De la Justice, that we will now turn, beginning with La Guerre et la Paix. 


\section{Chapter 5}

\section{War and Change}

Immanence et réalité de la justice dans l’humanité, tel est le grand enseignement que nous donne la guerre. ${ }^{1}$

\section{Introduction}

The purpose of the thesis thus far has been to provide the intellectual and socio-political context within which Proudhon wrote La Guerre et la Paix and to discuss the evolution of his thinking leading up to his turn to the subject of international relations. Since $\mathrm{La}$ Guerre et la Paix has been consistently misunderstood, these mis-readings have led to erroneous portraits of Proudhon - and particularly this aspect of his work. Thus, the extended contextualisation has been necessary to substantiate and give weight to the reading of the works that I will provide here and in the following chapter.

As the opening epigram of this chapter suggests, war and peace was the primary case study for Proudhon's theory of justice. The following analysis of La Guerre et la Paix will therefore extend and substantiate the analysis of the immanence of justice in the previous chapter. I do this by showing how Proudhon saw systems of morality to be in a constant state of change, with war the primary motor of that change. Framing the issue in this way was entirely in keeping with the dominant ways of conceptualising war and morality in the eighteenth and nineteenth century, as I have shown through my analysis of the work of Rousseau, Kant and Comte. Proudhon's ideas are framed almost entirely through the lens of the role of war in human history, and given his historical location, are also cast as his philosophy of history; or, as the title of the unaltered ninth étude of De la Justice states the problem, in terms of progress and decline.

\footnotetext{
${ }^{1}$ Proudhon [1998b], p. 172.
} 
The conclusion of the previous chapter was that for Proudhon justice was real, relational, human in terms of its origin but also fundamentally social. In order to cast it in this way, Proudhon had to eschew the standard epistemological debates of his time in favour of a “revolutionary ontology”. Coupled with Comte’s idea of forces, Proudhon suggested that we could better account for (as opposed to rationally deduce from first principles) the differing perspectives on the nature and source of justice, and its historical evolution. As it was for each of his main influences, I will show how this analysis was also the basis for his normative project.

It will be also reinforced here that Proudhon was anti-transcendentalist and nondogmatic, but like everyone bar the sceptics he sought some sort of foundation for morality and right that was not dogmatically idealist, rational or divine. Following the work of Comte he turned to history and sociology to develop Kant's philosophy of right, a discussion which Comte subsumes within the "organic doctrine”. Contrary to Comte's history-ending aspirations, Proudhon wanted to show that it is struggles for justice that animate bellicosity, also that force underpins all systems of right and that our individual and collective reason gives meaning to that force and justifies it. These justifications are in no way transcendental, and where they are brought into question by independent and free thought, we ought to expect conflict, as Comte rightly saw. But for Proudhon this conflict is both natural and, as we shall see, right-making, and needs to be understood and worked with, rather than abrogated according to the dictates of the "Priest Scientists". War is thus social conflict by other means, and on a vaster scale, but undertaken almost exclusively by states. It is this final feature of war that interests Proudhon most. But in this sense he was doing precisely what Kant admonished the average man not to do - he investigated the actual, empirical history of the state. This in itself was a revolutionary act.

It was also a gargantuan task and one that on publication met with near universal critique, disbelief and dismay. This needs a brief explanation in order to show the value of returning to the intellectual and social context of the mid-nineteenth century. Before I provide a critical analysis of La Guerre et la Paix itself I will provide a brief history of 
the publication of the text and its immediate reception. I will then, in the second part of the chapter, provide a short analysis of the secondary literature on this text. In the third part of the chapter I turn to the text itself. The work is divided between five 'books' and the structure of the remainder of this chapter follows their line of reasoning, mainly because Proudhon's argument is very clear and is best understood if we follow his structure. Nevertheless, it is not without its flaws, and I continue the feminist critique of the previous chapter at the end of the analysis of each book. Again, my aim is to use Proudhon's ideas against him so as to develop them somewhat. Finally, what we find is that the prescriptive and avowedly normative element in the final book of the work is underdeveloped and something of an analytical letdown. In this sense Bourgeois is both right and wrong to argue, in a much cited quote, that while the problem is courageously posed in La Guerre et la Paix, it is elsewhere that we must seek the "la vraie solution Proudhonienne".2 My method and analysis has led me to believe, however, that the problem is in fact posed in De la Justice; La Guerre et la Paix is his case study work and the 'solutions', so to speak, come in Du Principe Fédératif and De la Capacité Politique. Chapter 6 thus completes the analysis of Proudhon's later works by providing an analysis and critique of the detail of these solutions. In the conclusion to the thesis I illustrate the value of the work for the contemporary study of international politics, particularly in relation to the contemporary theoretical tools and problem fields of the discipline of IR.

\section{A Brief History of the Text}

Proudhon went into exile in July 1858 to avoid another prison sentence for the publication of De la Justice. Choosing Brussels arguably gave Proudhon a perspective on European politics his compatriots and revolutionary comrades exiled to England would not have had. As I discussed in chapter two, and as Proudhon's output prior to La Guerre et la Paix attests, the traditional focus of the European left was domestic politics and the largely domestic effects of capitalism - and when it was not French domestic politics that was at the forefront, it was the English economy. Thus, French preoccupations with equality and the state, the nation and so on, were usually cast in domestic terms -

\footnotetext{
${ }^{2}$ Bourgeois [1927], p. 26.
} 
focusing largely on the promise of the Revolution for French society, and ultimately what it promised for European society. Thus, when Louis Blanc and others went into exile in Britain, shocked at the effects of liberalism and worried about its potential effects in France, he retained a distinctly French, domestic and ultimately chauvinist focus. Where international relations featured at all it was as a call for the French to invade England and bring civilization and all its promises to its shores.

For Proudhon the story is quite different. Within a year of being in Brussels, rather than invading England, as Blanc had called for, France invaded Italy and, as I discussed in chapter one, only the French Catholic clergy expressed any serious misgivings about this. Whereas in England liberalism was the chief enemy for socialists, for Proudhon nationalism and statism were the most immediate problems. What soon became clear to Proudhon, was that the clamour for the abandonment of the 1815 settlement, and the championing of 'national self-determination', was dangerous. This, despite the fact that is was a settlement that was imposed by the Holy Alliance of liberal and absolutist states against the putatively republican France. This was a paradoxical position to hold for a self-professed revolutionary.

Then, towards the end of the year, from October to November 1859, the Proudhon family was struck with a severe bout of scarlet fever. Proudhon, having just returned from a spa where he hoped to recover more fully from the cholera he contracted in prison years before, was suddenly and for the first time the nurse, mother and father to the family, with his wife seriously ill too. Then, on the $25^{\text {th }}$ of November, Proudhon's daughter Stéphanie died from her illness. In May 1860 his brother also died in poverty. Some commentators have suggested that this personal tragedy imparted the pessimism and bellicosity of the work. But this overlooks the seriousness with which he approaches his subject and excuses his conclusions as reflections of mood rather than conclusions drawn from analysis. In this respect it is perhaps better to agree with Haubtmann, that for the next two years, Proudhon's life was almost wholly intellectual and Proudhon went from being a "consultant moraliste" during the research and penning of De la Justice, to retreating from public life almost entirely. Whereas De la Justice was notably biographical, this work was not. Haubtmann continues, “jamais l’histoire de sa vie n’a été 
plus dépendante de l'histoire de sa pensée", 3 and the marker of his life and work at this period is their intellectualism.

La Guerre et la Paix, unlike most of his other works, is not a reaction to any particular question, nor is it a response to any particular issue. It is not a reflection on recent events, nor is it a response to critique. Unlike What is Property? it was not the result of a competitive scholarship, nor unlike Théorie de l'Impôt (1860) was it in pursuit of a prize (which he eventually won). La Guerre et la Paix is entirely devoted to the intellectual task it sets itself: to understand, as the subtitle makes clear, 'the principle and the constitution of the rights of nations' through an analysis of the relationship between justice and war in human history.

But despite this intellectualism, it was no easier to publish than any of his earlier works. By October 1860 it was becoming clear that Garniers, his usual publishers, having been fined a considerable amount and threatened with jail terms for publishing De la Justice, were reluctant to go ahead with publication. Eventually they decided that, because he was criticising Grotius, Vattel, Wolf, Pufendorf and Kant, and because he looked to war to find the origins of right, that he was attacking the imperial power of France and would therefore be a liability for them. ${ }^{4}$

This infuriated Proudhon since his motives were in this case intellectual as opposed to political. As he remarked to Hetzel in January 1861 “J’ai fait cet ouvrage avec l'ambition de le rendre classique: c'est un traité sur les principes du Droit des gens destiné à renvoyer au grenier tout ce qui a été publié sur ce sujet depuis Grotius et Vattel.”5 After some persuasion, Hetzel himself was persuaded to publish the work simultaneously in Paris and Brussels with Dentu. But by then, the spin Proudhon had put on the work was to make it almost entirely a work in the tradition of the philosophy of right. But as he made quite clear later in a letter to Charles Beslay, he expected the work to also be an

\footnotetext{
${ }^{3}$ Haubtmann [1988b], p. 176.

${ }^{4}$ This is Proudhon's reading of the situation. See the excellent collection of letters reprinted as an appendix to the 1998 edition of La Guerre et la Paix. Proudhon [1998b], p. 224.

${ }^{5}$ Ibid., p. 226.
} 
instruction to strategists, lawyers, men of letters and publicists. ${ }^{6}$ The final version also includes ruminations on the political problems of his time, as I will show.

His publishers demanded four revisions before they were happy with publication, resulting in one of the most revised of Proudhon's works, and page-for-page, perhaps the most systematic, rigorous and accessible as a result. But once it was eventually published, on the $22^{\text {nd }}$ of May 1861, it was met with near universal disdain, disbelief, misunderstanding and critique. "ON NE ME COMPREND PAS"” he cried in letters to friends. And subsequent readings of the work have rarely been either accurate or fair. Ironically, despite such care in the editing, few understood the work, or took the time to try. The most notable exception was Count Leo Tolstoy, who used the title of the work and its sentiment to animate what is perhaps the most significant novel in history. ${ }^{8}$ This split in the secondary literature therefore needs some explanation.

\section{The Secondary Literature}

The themes of the critiques of La Guerre et la Paix might usefully be divided in three. There were those of his contemporaries who saw him as glorifying war, others who saw it as the epitome of his confused (if not paradoxical) mind, and those twentieth century readers who have since tried to understand it through Hegelianism. Most of these readings are drawn from the first book of the five which comprise the two volumes, and suggest that readers rarely read much further. I will now engage with each in turn.

In a letter to Rolland, Proudhon recounted that even friends like Charles Beslay claimed they simply did not understand him, and where they did they disagreed with him. Beslay

\footnotetext{
${ }^{6}$ Ibid., p. 232.

${ }^{7}$ Cited in Haubtmann [1988b], p. 209.

${ }^{8}$ Tolstoy visited Proudhon in Ixelles in 1860, having obtained a letter of introduction from Alexander Herzen. They spent days discussing the issues that came to animate both works - morality, the role of war in overturning social customs, and the Napoleonic campaigns in particular. When La Guerre et la Paix was translated into Russian in 1867, Tolstoy took the title of the work for his own. Sampson [1973];

Eikhenbaum [1982], pp. 175-194. Others downplay this relationship. See, for example, Wilson, [1988], pp. 164-165; Simmons [1949], pp. 182, 214, 304-305; Maude, [1908], p. 211. But Tolstoy’s religious anarchism is no quirk when we understand this connection and context, moreover, the philosophical ruminations in the epilogue to Tolstoy's War and Peace can be traced directly to Proudhon. To demonstrate this would, however, be beyond the scope of this thesis.
} 
claimed Proudhon was a militarist and glorifier of war, while he, Beslay, a new type of anti-militarist in French history, was not. ${ }^{9}$ The newspaper the Nord reprinted the preface with a reminder that France had been beaten by the Austrians and that France's national glory, or the glory of any military was not to be praised. ${ }^{10}$ Both reports portended worse to come but also reflected the shift in attitudes on the left away from unrestrained praise of the French military at the turn of the century, to Proudhon's support for the antimilitarist Catholic and liberal pacifism that sought the contradictory ends of national selfdetermination and liberal peace at once. The question of the justice of the 1815 treaties and the European balance of power generated epochal questions in the minds of Proudhon's readers, mainly because it did not offer any easy solutions or suggest any inevitable futures.

The opinions espoused by E. H. Carr (cited in the introduction above), concerning Proudhon's assumed chauvinism, are also typical of most reactions to the work. Proudhon's stand against the overturning of the 1815 treaties was also seen to be capitulation to the very forces he had spent so long denouncing, while others thought of it as simply confusion or another example of Proudhonian paradox. Proudhon's extended discussions on the role of religion in the evolution of justice and war was grasped by his critics as an example of his capitulation to, or worse, the praise of the dogmas of the Church. ${ }^{11}$ All this amounted to re-igniting the view that Proudhon was too paradoxical to be taken seriously; a view that has persisted to this day. The role of religion in this aspect of his thinking is clarified below.

Even supportive reviews highlighted the presumed paradoxical nature of Proudhon's thought. A review by Proudhon's friend Gustave Chaudey, in a Sunday newspaper published on the $21^{\text {st }}$ of July $1861,{ }^{12}$ argued that the cause of the dismay was both the polarisation of society and Proudhon's engagement with themes not usually combined in

\footnotetext{
${ }^{9}$ Proudhon [1998b], p. 247 Incidentally, Beslay became the President of the Paris Commune. See Vincent [1984], p. 232.

${ }^{10}$ Ibid.

${ }^{11}$ Hoffman opens his chapter on Proudhon's approach to war and history with a cartoon from Le Charivari dated February $18^{\text {th }} 1849$. It depicts the then common perception of Proudhon's paradoxical vacillation between religiosity and atheism and its reprinting here does nothing to lessen the effect of this excellent selection of cartoons. Hoffman [1972], p. 260.

${ }^{12}$ Discussed in Moysset [1982], p. xxxiv.
} 
social theory. Chaudey argues that the military were suspicious of his praise of force and the seemingly paradoxical conclusions against the science of strategy. The aristocracy did not like reading democrats such as Proudhon asserting their right to force, while also showing the centrality of force to the history of the founding of the state. The liberal economists, careful to delimit their intellectual contribution, but clearly indebted to the Comteans and Saint-Simonians, did not want to be implicated in the widespread apology for militarism but saw the socialist solution to be even more problematic. And this was equally true of the intellectuals of the period who resented ridicule from someone they saw as a self-taught upstart.

To recap arguments made in the introduction, the contemporary English secondary literature on this aspect of Proudhon's thinking is largely unhelpful. Hoffman's view is symptomatic of a more widespread reluctance to return to this aspect of Proudhon's thought when he argues that,

La Guerre et la paix [...] is more philosophy of history than anything else. However, although many of the ideas it presents have general importance for his philosophy, the peculiar view of history in La Guerre really seems to be little more than an awkward effort to provide a rationale for conclusions that he would have done better to offer and argue far differently. ${ }^{13}$

Hoffman's analysis, informed by a more Marxist and materialist philosophy of history, ${ }^{14}$ seems to be quite clear in arguing that this work can be ignored. Added cause to do so is provided by the standard confusion as to whether La Guerre et la Paix is an exposition of a Proudhonian theory of the dialectic or something else. Moysset, in his introduction to the Marcel Rivière edition, argues that Proudhon sees the sublime nature of the 'idea' of war as the thesis, with its ugly brute reality the antithesis. The synthesis is the changed social relations or "l'idée de droit" which emerges. ${ }^{15}$ This, as I will show, comes closer to

\footnotetext{
${ }^{13}$ Hoffman [1972], p. 261.

${ }^{14}$ For example Hoffman reduces Proudhon's argument to one about "progress" and argues that Proudhon is not clear enough. In fact, "[a]though he sees history in terms of social revolution, he is unable to develop a theory of process comparable in analytic precision and force to Marx's dialectical materialism”. Ibid., p. 626.

${ }^{15}$ Moysset [1982], pp. xxv, liv.
} 
the truth, and goes some way towards refuting Peter Marshall's claim that because Proudhon opposes an appreciation with a critique of war that " $[\mathrm{t}]$ he work bears witness to the paradoxical nature of Proudhon's mind”16. But it remains problematic given my argument in the previous chapter that the dialectic is not Proudhon's method at all. It is interesting to read Bourgeois in this context, who claims the work aims to "résoudre les antinomies de la raison politique", ${ }^{17}$ but this too is somewhat misleading. As Mark Weitz has argued in the only English introduction to this work, it is more obvious to him that the Hegelian progressive dialectic is not Proudhon's method. According to Weitz' reading of the dialectic, for Proudhon "there were no final triumphs". ${ }^{18}$

Proudhon's letters could have helped here, for they show that it is not Hegel but Kant that is the key foil for Proudhon's argument. For example, Langlois, another friend of Proudhon's, was far more complementary. In a personal letter, to which Proudhon replied enthusiastically, Langlois compares Proudhon to Copernicus and Galileo in having found the principle of social movement. Proudhon was obviously grateful, but nevertheless has to correct his impression that he had set out to ruin Kant's theories and reputation in order to assert his own. Proudhon argues quite the opposite.

Vous n'êtes pas juste à l'égard de Kant. Je me moque de ses livres gothiques et de leur forme trop souvent inintelligible. Mais il ne me paraît pas possible de lui refuser la plus grande gloire qu'ait méritée un philosophe par la seule manière dont il a posé le problème religieux et philosophique. Songez que c'est à lui, en définitive, que revient l'honneur d'avoir réduit à sa juste valeur l'absolu. Kant nous a appris à ne plus nous demander: Qu'est-ce que Dieu? par exemple, mais comment croyons-nous en Dieu? Descartes n’est pas arrivé là. Au contraire, c’est lui qui a posé ... la réalité propre d'un monde spirituel ... Ne médisons pas de Kant, cher ami, ou nous retombons dans le mysticisme et les tables tournantes. ${ }^{19}$

\footnotetext{
${ }^{16}$ Marshall [1993], p. 251.

${ }^{17}$ Bourgeois [1927], p. 36.

${ }^{18}$ Weitz [1972], p. 15.

${ }^{19}$ Proudhon [1998b], p. 249.
} 
What we see here is that the defence of Kant is vital to Proudhon's own intellectual integrity, but we also see the confusion the book had raised. For all its reference to Grotius and Vattel and the rest of the 'miserable comforters' (as Kant called them), the true inspiration for the work is Kant's philosophy of right - as I will show - and his critique of Kant masks a profound debt to him. It is perhaps precisely because Comte and Kant were so distant from the revolutionary tradition, and largely remain so, that others have not seen these influences on Proudhon's thought, and why a good understanding of it has thus remained elusive.

By and large his friends did not understand him and his enemies rejoiced in his seeming renunciation of the revolutionary left. Perhaps it would therefore be correct to conclude with Bourgeois that “[s]es idées sont bien ici sa propriété personnelle.”20 But this would be overly generous and only half-true. My argument is that Comte and Kant are significant and unacknowledged influences on Proudhon's ideas here as much as Proudhon was responding to and reinterpreting key trends in French social and political thought. Without the context of the previous chapters it would be very difficult to make these arguments - more difficult still to provide the exegesis that follows.

\section{The Text}

What I will do here is develop an analysis of La Guerre et la Paix that follows the structure of the work closely but diverts from this structure to contextualise and explain key arguments, engage with some of the most long-standing mis-readings of the work, and also to develop my feminist critique of them.

La Guerre et la Paix is divided between five books. The first outlines the "phenomenology of war". Proudhon's argument is that if we want to analyse war we must first understand, or at least state what it is we think war is. ${ }^{21}$ Here we are treated to a Kantian/Comtean inspired analysis of the ontology and history of conflict in the idealisation of human life - one that builds directly from the analysis I presented in the

\footnotetext{
${ }^{20}$ Bourgeois [1927], p. 69.

${ }^{21}$ Proudhon [1998a], p. 37.
} 
previous chapter. It is this book which raised so much misunderstanding vis-à-vis Proudhon's assumed 'panegyric' to war and his praise of religion. The second book does not help matters and outlines his theory of the "droit de la force", suggested first by the Catholic theocrats and adapted by Comte, again by developing arguments first made in De la Justice, but here applied to world politics. Proudhon shows how the right of force and of war derives from the "organe de la justice". ${ }^{22}$ Book three turns to the forms of war. Confusion regarding the possible use of the dialectic as a method and structure to the work is caused by this book. In the summary to the book Proudhon argues that a “contradiction perpétuelle [existe] entre la théorie du droit de la force et son application." ${ }^{23}$ But he is clear that this contradiction is permanent - i.e. it cannot be overcome, nor is it necessarily progressive as my analysis of Proudhon's use of the analogy with duelling will show. In book four, Proudhon provides the first economic history of state formation, the role of industrialisation of the means of warfare in the consolidation of state power, and the organisation of the economy for the purpose of maintaining the state's grip on society. Book five seeks to offer a way out of this historical development but arguably fails because of a logical contradiction Proudhon is necessarily faced with. Proudhon tries to argue that the new industrial working class is the future, but he can see how they may actually be the problem in the short term. He wants to point to the new industrial worker as humanity's saviour but he sees, and argues throughout, that the industrialisation of warfare is not a positive fact. He wants to agree with Kant and others that war is a progressive educator, but he can not bear to see what the next lesson might be.

This tension is very uncomfortable for the reader and it was not discussed and developed further until he came to write the Principle of Federation and De la Capacité Politique des Classes Ouvrières. These are the focus of the following chapter and provide the mature statement of his normative anarchism.

\footnotetext{
${ }^{22}$ Ibid., p. 85.

${ }^{23}$ Ibid., p. 202.
} 


\section{Book 1: The Phenomenology of War}

Proudhon argues that we will never have a sufficient idea of the causes and historical trajectory of war until we have a better idea of what war actually is. ${ }^{24}$ While the material reality of war, strategy and so forth have their place in its analysis, and book three deals with this area at length, here Proudhon argues that if we focus on the movements of armies on maps, or count the numbers of guns and soldiers in any given battle, we miss its most crucial elements. ${ }^{25}$ These are the romanticised and heavily idealised renderings of war in popular literature, in the Bible and other popular mythologies, the moral animus of warriors and military leaders, and the permutation of rationalisations of conflict into 'collective reason' and the role of collective reason in sanctifying conflict. Thus he begins by reframing the phenomenology of war and directing his readers to its moral content.

\section{The Moral Ontology of Conflict}

Proudhon's approach to war develops directly from his thinking about justice, and was largely typical of nineteenth century approaches to the subject. As I discussed in the previous chapter, conflict and antagonism are central to his theory since moral norms emerge out of both ideational and material conflict premised upon individual moral prerogatives and the conflict for the material resources to realise them. This formulation is embedded in a relational social ontology which he brings forward to this work.

Pour qu'il y ait action, exercice physique, intellectuel ou moral, il faut un milieu en rapport avec le sujet agissant, un non-moi qui se pose devant son moi comme lieu et matière d'action, qui lui résiste et le contredise. L’action sera donc une lutte: agir c'est combattre. ${ }^{26}$

\footnotetext{
${ }^{24}$ Ibid., p. 37.

${ }^{25}$ Ibid., p. 36.

${ }^{26}$ Proudhon [1998a], p. 63.
} 
Proudhon argues that it is impossible to assume a society without conflict. The very fact of our difference, he argues, makes the rational universal accord that Kant advised us to believe in, impossible and, he adds, "que cela est bien."27 Nevertheless, in a direct echo of the dominant nineteenth-century approach to the subject, and Kant's in particular, he argues that antagonism and conflict are progressive overall because they are the very precondition of social mobility and change. Conflict and antagonism will not lead us inevitably towards a pre-defined Kantian 'Kingdom of Ends', but their value lies in their ability to simply move or change society.

Conflict, however, is not only ideational and social, it is also exacerbated by humanity's historical conflict with nature and the emerging ways in which we have dealt with and rationalised this conflict. Following Comte, he argues that the first stage of this rationalisation was religious. In this pre-scientific era, he argued, war was and in many cases remained, rationalised as "divine”. This statement has caused much confusion, but he defines what he means by divine almost immediately. Divinity is humanity's inability to find real causes and our investing of forces we cannot understand with personified agency - clear if unacknowledged use of the Comtean concept of 'fetishism'. Thus, for example, the origins of human life are "divine" in much the same way as war is considered divine by those who retreat to theology to explain it - and as we have seen, that is exactly what Kant, Rousseau, De Maistre and others did. Here war becomes "theophany" or the manifestation of the divine. But, Proudhon argued, "[s]i jamais la science pénètre ce mystère, la divinité de notre origine sera reculée, le fait même de notre terrestre existence cessera d'être divin; ce sera un fait scientifique." ${ }^{28}$ Proudhon hoped to pierce "cette affreuse superstition”29 and hoped that by doing so it would cease to hold such a grip on society. Understanding war and religion in this way was in no way idiosyncratic, but his originality was to use his approach to argue against the ideas of Comte and the implicit imperialism of others who called for a united states of Europe, universal empire, or a fixed, republican global federation. Proudhon was clear that this would be the wrong way forward.

\footnotetext{
${ }^{27}$ Ibid., p. 64.

${ }^{28}$ Ibid., p. 38.

${ }^{29}$ Ibid., p. 89.
} 
L’idée d’une souveraineté universelle, rêvée au moyen âge et formulée dans le pacte de Charlemagne, est la négation de l’indépendance et de l'autonomie des États, la négation de toute liberté humaine, chose à laquelle États et nations seront éternellement d'accord de se refuser. De plus, ce serait l'immobilisme de l'humanité, absolument comment le despotisme dans un État, ou le communisme dans une tribu, est l'immobilisation de cet État et de cette tribu. La civilisation ne marche que par l'influence que les groupes politiques exercent les uns sur les autres, dans la plénitude de leur souveraineté et de leur indépendance; établissez sur eux tous une contraigne, le grande organisme s’arrête; il n’y a plus ni vie ni idée. ${ }^{30}$

Thus to keep the dynamism of history and to protect the liberty that is at its heart, Proudhon had to maintain the necessity of conflict and force but had to find a way of moving away from the conclusions of others. The question was not one of finding a transcendental principle of order, nor was it to retreat into a materialist fatalism. Proudhon used history as a tool of emancipation by showing how humans have created the very collective forces and rationalities of oppression that they believed were of either divine or transcendental origin - which amounted to much the same thing - and by so doing show how humans can, given the right conditions, change them. It is to this history of the idealisation of war that Proudhon then turned.

\section{The Evolution of the Idealisation of War}

Proudhon uses the insights provided by Comte and develops ideas he had been working with for twenty years. He shows how war has evolved, how this evolution can teach us about its role in society and how we ought to understand it. Proudhon argued that this evolution in the rationalisation of conflict has taken three distinct forms: religious, philosophical or metaphysical, and scientific.

Given the prevalence of conflict within human society and between society and nature, systems of thought must have arisen to give meaning to this conflict. Proudhon points out

\footnotetext{
${ }^{30}$ Ibid., p. 293.
} 
that throughout history most gods have been seen as warriors, in conflict with one another or with other forces. To make sense of the conflict between man and nature, religion gives meaning to the forces of nature in the absence of better explanations. Proudhon argues that religion served also to animate these acts in ways which were wholly legitimate at that time. It is a truism, but probably one worth repeating, that "[l]a même conscience qui produit la religion et la justice produisant aussi la guerre; la même ferveur, la même spontanéïté d'enthousiasme qui anime les prophètes et les justicières, emportant les héros : voila ce qui constitue le caractère de divinité de la guerre.”31 Proudhon asks: "qui ne voit que [...] la guerre a servi primitivement de moule a la théologie"? ${ }^{32}$ These myths and their concretisation as ritual and literature is historical evidence of the human rationalisation of war and conflict. "[S]i la guerre n'existait pas," Proudhon argued, “la poésie l’inventerait.”,33

Moysset in his notes to the 1927 Rivière edition to the work makes the important point that much of Proudhon's discussion in La Guerre et la Paix is informed by a Feuerbachian sociology of religion. ${ }^{34}$ In De la Justice Proudhon argued that "[l]a religion, en un mot, est le respect de l’humanité idéalisée et adorée par elle-même sous le nom de Dieu: là est tout le mystère.”35 Here he argues that this personification and misunderstanding of human agency is reified and institutionalised. ${ }^{36}$ As these religious ideas became sedimented in and through social hierarchies, ideas of right and justice, of conflict and war were given a temporal aspect in the judiciaries and state forms of antiquity but underpinned by theistic and transcendental justifications. With the unity of Church and State under Charlemagne this was made explicit. Proudhon also notes that historically the most religious and most righteously juridical nations have also been the

\footnotetext{
${ }^{31}$ Ibid., p. 40.

32 Ibid., p. 44. cf. Comte [1968c], pp. 44-58.

${ }^{33}$ Proudhon [1998a], p. 55.

${ }^{34}$ Ibid., p. 45.

${ }^{35}$ Proudhon [1988/1990d], p. 2056.

${ }^{36}$ Haubtmann [1980] contains Proudhon's annotations of Fauerbach's work on Christianity, penned around this time.
} 
most war-like, ${ }^{37}$ and that with time he argues, Islam ought one day to supersede Christianity in its martial impulse. ${ }^{38}$

Turning from collective reason to the place of the individual warrior in human history, Proudhon shows how he has invariably been seen as "plus grand que la nature [...] Le guerrier est sacré pour la punition du crime et la protection du faible: telle est la première forme de la justice dans la société [...] Le véritable Christ, pour les masses, c’est Alexandre, César, Charlemagne, Napoléon.”39 The collective rationalisations and personifications of broader natural and inexplicable processes becomes fused and realised in the mythical leaders of the past. Order became both dependent upon and the preserve of the military and religious caste, or those with the closest connection to the Divine and those who controlled the means of war. Right and wrong, law and order are all derivative of the idealisation of the symbols of power and the material force that supports them, or in other words, "collective reason" and "collective force” are interdependent, war is their nodal point, and religion and war is the historical foundation of right and law.

Christianity rationalised war as a manifestation of original sin, and the Catholic theocrats like de Maistre and Ancillon were the eighteenth-century manifestations of this same train of thought. This now late-feudal rationalisation retained social hierarchy in the name of a religious rationalisation of social order and conflict. Proudhon refers to their texts repeatedly as evidence of historically contextual rationalisations of the social order. But the problem with the doctrine of original sin that underpins this literature, especially as an explanation for war is that it locks us in "le cercle vicieux" 40 and closes off our ability to look at change in moral systems of thought over time. It does this by positing the truth of original sin as a rational and ahistorical apriori assumption. This appeal to rational and ahistorical aprioris is also a feature of the metaphysical state and these debates were

\footnotetext{
${ }^{37}$ Proudhon [1998a], p. 52.

${ }^{38}$ Ibid., p. 43 These notes cannot possibly capture the depth of historical knowledge Proudhon brings to bear on this subject, not are they meant to sound particularly prophetic. We will see that Proudhon's primary explanation for the causes of war are economic not religious. For a full analysis of this subject see Jourdain [2006]. By making Proudhon’s ideas contemporary however, Jourdain's analysis overlooks the fact that La Guerre et la Paix (and also De la Justice) provides one of the earliest and most suggestive sociologies of religion and of war.

${ }^{39}$ Ibid., pp. 67-68.

${ }^{40}$ Ibid., p. 62.
} 
discussed in detail in the previous chapter. What is significant is how Proudhon links the metaphysical with the religious in much the same way Comte did and how little detailed attention he pays to this stage in his historical narrative.

The scientific era, of which Proudhon saw himself to be a part, sought to break the religious, metaphysical or transitory spell that these early mindsets had cast over people. For Proudhon it was important to see conflict as a "category" or innate faculty of the mind, reflecting conflict in the real world, in the antinomies of reason, and also in our trying to make sense of it by providing competing explanations. Reading the past was thus to provide a window into ways of thinking about social and ideational evolution and given the centrality of war to poetry, art, literature, philosophy and religion, it was clear, to Proudhon at least, that "qui sait la guerre, sait le tout du genre humain." ${ }^{41}$ It is crucial therefore to understand the idealist or psychological manifestation of war alongside its material evolution. For Proudhon, the material and ideal "s'impliquent et se supposent”. 42

But we must wait for books three and four to understand the sheer scale of this relationship. In Books I and II, Proudhon focuses entirely on the ideal. Unfortunately for Proudhon, it is because he refused to qualify his argument in the first books that people have come to see it as a panegyric to war. But for careful and more patient readers the depth and sophistication of the argument is striking and, as a result, uncomfortably elegant and poetic. His respect for our psychological past is profound because of the ideas of valour, justice and right that permeate the literature he discusses. Irrespective of the flawed basis upon which this past is built, they reflect ideas which are intimately human and remain an integral part of our contemporary collective existence. But this does not make them transcendentally right.

\section{Peace and the Feminine}

Proudhon's treatment of the role of women in history in this first book stands in stark contrast to these observations. What we see here is that Proudhon's works were no less a

\footnotetext{
${ }^{41}$ Ibid., p. 46.

${ }^{42}$ Ibid., p. 54.
} 
reflection of his times (and, unfortunately of our own). He was fully cognizant of the critiques of his own position, and he came to his conclusions independently, even if he was merely repeating the standard conventions of his day. Despite his scientific pretensions, and despite being fully acquainted with authoritative feminist arguments, ${ }^{43}$ he argues the following in a footnote:

Entre l’homme et la femme, la guerre crée une inégalité colossale, irréparable [...] l'incapacité militaire de la femme en vaut des millions. La femme n’a vraiment d'existence que dans la famille. Hors de là, toute sa valeur est d'emprunt; elle ne peut être rien, elle n’a le droit de rien être, pour la raison décisive qu'elle est inhabile à combattre. ${ }^{44}$

Women, he argued, are enamoured of the virility of the warrior, a natural act of adoration, and since, he argued, civic and social participation characterised as struggle and war, women can have no political role beyond this adoration. "Le Peuple" Proudhon argues, "est de l'avis des femmes. Partout l'homme de guerre est noble; il fait caste.”45 Moreover, peace is epitomised by a goddess, and the pacifist currents of the SaintSimonians and the Fourierists is a 'mere' extension of this feminism. For Proudhon, pacifism is a sign of encroaching weakness in man since Proudhon sees it as a natural weakness only in women.

Jenny d'Héricourt's work was discussed in chapter two. It is worth remarking here that she too followed a similar line of argument to Proudhon, turning to history to furnish her counter arguments and as a tool of emancipation. In a work that pre-dated Proudhon's analysis of war by at least a year she argued against him in the following way:

You say ... she cannot be a political leader ... And history shows us a great number of empresses, queens, regents, sovereign princesses who governed wisely, gloriously, proving themselves vastly superior to many sovereigns ...

\footnotetext{
${ }^{43}$ Haubtmann notes that he discovered many of these works in his library and fully annotated, indicating both Proudhon's familiarity with the science of sexual equality and his prejudiced refusal to accept them. [1980], p. 67.

${ }^{44}$ Proudhon [1998a], p. 68, n. 106.

45 Ibid., p. 70.
} 
[You say] [w]omen cannot be philosophers or professors ... [but] Hypatia, massacred by the Christians, professed philosophy brilliantly ... in France at present, many graduates of the Ecole polytechnique set great store in [the] geometrician Sophie Germain, who dared to understand Kant ... The argument presented by Mr Proudhon is, as we have just seen, contradicted by science and fact. ${ }^{46}$

Indeed, the history since Proudhon's death further supports this argument. With the increasing industrialisation and totalisation of warfare, a nascent process of which he alone gave the fullest account at this time, women have taken on roles in the production of the instruments of war, and in its execution. Historically we know that this was consolidated after the slaughter of two world wars. Moreover, the extension of suffrage was intimately linked to this slaughter and the role of women in fighting and supporting a war effort for the protection of their society. Why Proudhon refused to see this historical process, which was underway by his time and women such as d'Héricourt had already pointed to, when he was so prescient about so much else, needs explaining. This is a first order contradiction in his thinking as a whole. But it is one that can be corrected using his theory and concepts.

By way of conclusion, in this first book Proudhon goes to great lengths to illustrate the intimate connection between war and our psychological evolution. "C'est dans la conscience universelle que nous devons l'étudier, non sur les champs de bataille, dans les sièges et les chocs des armées.” The materialism of war, he argues, can teach us very little about its history or the history of its philosophy. War is "une puissance de notre âme, elle a sa phénoménalité dans notre âme."47 It is this reframing of the ontology of war that allows him to take the directions he does with his argument.

\footnotetext{
${ }^{46}$ Cited in Primi [2006], p. 154. The additions are my own.

${ }^{47}$ Proudhon [1998a], p. 80.
} 


\section{Book II: The Right of Force}

This second book is far less structured than the previous one and its argument is highly contentious and this makes a good understanding of it even more difficult. Many of the themes Proudhon discussed in this book needed the contextualisation of the previous chapter in order to render them intelligible. Proudhon discusses four things here. First, he argued that the evolution of the rights of nations (droit des gens) has run parallel to the psychological evolution of our rationalisation of war. Secondly, this parallel evolution can be understood to be linked via the relationship between force, war and law. What this demonstrated for Proudhon was that a tacit, conventional right of force exists, but that it is denied by both the academy and the Church. Approaching force both materially and ideationally as he does provides us with a far deeper sociology of interstate relations and war and a far deeper philosophy of history than that provided by Kant, Comte or Rousseau. However, in the final section I turn to Proudhon's discussion of the family, the primordial locus of the right of force as I illustrated in the previous chapter, which he here seems to place outside his general theory, which is logically inconsistent and unnecessary. This discussion continues the immanent, feminist critique of this work.

\section{The Right of Force}

First, Proudhon defines force like this:

La matière est une force, aussi bien que l'esprit; la science, le génie, la vertu, les passions, de même que les capitaux et les machines, sont des forces. Nous appelons puissance une nation organisée politiquement; pouvoir, la force politique, collective, de cette nation. De toutes les forces, la plus grande, tout dans l'ordre spirituel et moral que dans l'ordre matériel, est l'association, qu'on peut définir l'incarnation de la justice. ${ }^{48}$

\footnotetext{
${ }^{48}$ Ibid., p. 140.
} 
Association and force are thus intrinsic to justice as we discussed in the previous chapter. Rights, on the other hand, emerge "directement de la faculté qui sert à le définir, dont il est la couronne et la sanction." 49 The key is to understand rights serially and socially, which is to say in their order of emergence from between individuals up through the associations they form. ${ }^{50}$

Le droit, en général, est la reconnaissance de la dignité humaine dans toutes ses facultés, attributs et prérogatives. Il y a donc autant de droits spéciaux que l’homme peut élever de prétentions différentes, en raison de la diversité de ses facultés et de leur exercice. La généalogie des droits suivra en conséquence celle des facultés humaines et de leurs manifestations. ${ }^{51}$

Proudhon grounds his conception of rights in man's place in nature and society. Here he argues that the right of force is the most elementary of all rights because it is primordial. He also argues that it is indispensable in that the right of force is necessary to animate all other rights built upon and used to rationalise this basic right of force. ${ }^{52}$ Force is as human and social as any other faculty, perhaps even their precondition, and the purpose of social regulation is to harmonise our other rights and faculties and hold them in a state of social reciprocity or emergent equilibrium. To maintain this order, force is needed since without force rights atrophy or become superfluous due to changed social circumstances. As such, force is both rational, rationalised and reciprocal. It is given meaning in relation to the other rights and needs to be balanced with them, in and through specific social contexts.

The "organe de la justice", 53 or in other words human moral agency, is therefore central to understanding Proudhon's ontology of war and order. The aim is to unite both material and ideational forces in his ontology of order. "De l’ordre intérieur dépend la

\footnotetext{
${ }^{49}$ Ibid., p. 139.

${ }^{50}$ Here Proudhon makes direct reference to Fourier's theory of the serial dialectic but does not elaborate its detail.

${ }^{51}$ Proudhon [1998a], p. 189.

${ }^{52}$ Ibid., p. 189 (emphasis added).

${ }^{53}$ Ibid., p. 85.
} 
tranquillité au dehors: cela est aussi certain qu'un axiome de mathématique."54 Moral and juridical norms are thus powerful constraints on the actions of individuals and groups and while force has its place, its materiality ought not to be conflated with its ideational aspect. Only through keeping the two separate and by recognising their relative autonomy and interaction can we account for the power of law. Proudhon argues that the key to understanding how law evolves is through understanding conflict, and, since war is the most striking example of conflict in human society, this is where we ought to look to find the evidence for this genealogy.

\section{War, Law and the Evolution of the Rights of Nations}

According to the jurists and the academy, Proudhon argued polemically, justice is either unilateral in international relations or it is absent - the two or more parties to a dispute cannot all be right. Secondly, Proudhon also claims that if war were understood to be integral to our understandings of law and right, "cette affreuse guerre" would destroy Kant's philosophy of right. ${ }^{55}$ For most, either combatant A or B is just, or no one is, or it is assumed that in war, law no longer has any domain. Against this, Proudhon argues that both sides must at least believe they are right, irrespective of whether they are or not, or we cannot account for why people fight at all.

The abstraction of the state of nature, the then typical means of understanding this conundrum, also allowed the philosophers to claim that war was extra-judicial. However, Proudhon argued that if viewed sociologically, we would see that "la guerre [est] entourée d'honneurs, de formalités légales, de cérémonies religieuses, comme un acte saint et sacré”. ${ }^{56}$ The realist moral and social ontology Proudhon stressed above helps us see why he thinks it is important to see that soldiers idealise their missions, believe they are fighting for a higher Revolutionary cause. Manning the barricades was not solely an act of materialistic egoism, nor dispassionate reason as Kant rightly saw. In statements that inevitably generated claims that he was a chauvinist and glorifier of war, Proudhon argued,

\footnotetext{
${ }^{54}$ Proudhon [1998b], p. 71.

${ }^{55}$ Proudhon [1998a], p. 114

${ }^{56}$ Ibid., pp. 89, 96-97.
} 
la véritable représentation d'un pays, dans ses rapports avec l'étranger, est son armée; que, comme cette armée est la force du peuple, elle en devient, en cas de guerre, la conscience; que même dans la prévision de la défaite la guerre est pour le citoyen le plus sacré et le plus glorieux des devoirs, parce qu'il s'agit de sauver la patrie... ${ }^{57}$

Given the analysis of chapter two we can now better account for sentiments such as this and see how they were presented at the cusp of a transitional period in the rationalisation of war and the relationship of the French left to the army. In this respect Proudhon reflects traditional attitudes in arguing that armies reflect the moral and material society which produces them. But his point is also analytically suggestive since the way in which a country fights, its procedures and rituals, norms and atrocities, will always emerge from and reflect the ideational and material forms societies take at particular historical junctures. Soldiers, for better or for worse, always fight for something and soon lose the will to continue if they believe they are risking their lives for nothing. The ways in which soldiers are trained and the societies they come from will also shape the way in which they conduct themselves on the battlefield. This is not to claim that soldiers automatically internalise moral norms uniformly, nor to say that armies are an aggregate of human interests, or that an army's norms and interests are reducible to broader social interests. In fact, for Proudhon “[p]our qu'il y ait un véritable droit des gens, il faut donc qu'il existe dans l'être moral, qu'on appelle nation, un ordre de rapports qui ne se trouve pas dans le simple citoyen." 58 This emergent collective reason and collective force is here used to understand the reality of military codes of honour and élan, and to show how they are socially contextual and govern wars in very important ways.

These norms also govern the relationship of states with one another and emerge as the rights of nations. They are not transcendentally given, but historically emergent and contingent. They have evolved to moderate, control and provide the touchstone for social cohesion in new social conditions and depending on new intellectual and technological

\footnotetext{
${ }^{57}$ Ibid., p. 91.

${ }^{58}$ Ibid., p. 164.
} 
advances. With changes in both the emergent moral norms of a given society or the material capabilities of states in war, societies and their rationalisations change. Force and law are thus both central to war, and war and conflict are central to law.

[L]e droit de la force, le droit de la guerre et le droit de gens, définis et circonscrits comme nous venons de le faire, se soutenant, s'impliquant et s'engendrant l'un l'autre, gouvernent l'histoire. Ils sont la providence secrète qui mène les nations, fait et défait les États, et, mettant d'accord la force et le droit, conduit la civilisation par la route la plus sure et la plus large. Par eux s'expliquent une foule de choses dont il est impossible de rendre compte ni par le droit ordinaire, ni par aucun système historique, ni même par les évolutions capricieuses du hasard. ${ }^{59}$

It is worth noting here that Proudhon's conception of history's guiding hand is not one of chance, or of historical inevitability. The conception outlined here is of force guiding history through the widest and thus the least determined route, leaving the future and conceptions of right open. But if Proudhon is wrong, and war has nothing to do with right, then it would follow that,

Toutes nos institutions, nos traditions et nos lois sont infectées de violence et radicalement viciées; il s'ensuivrait, chose terrible à penser, que tout pouvoir est tyrannie, toute propriété usurpation, et que la société est à reconstruire de fond en comble. Il n’y aurait consentement tacite, prescription, conventions ultérieures, qui pussent racheter une telle anomalie. On ne prescrit pas contre la vérité; on ne transige pas au nom de l'injustice; en un mot, on n'édifie pas le droit sur sa propre négation. ${ }^{60}$

This is a clever twist. Proudhon had spent the previous twenty years denouncing the injustice of modern society and yet he seems here to be making a striking about-face. But the key aspect of this formulation is that, for better or for worse, liberty and openness,

\footnotetext{
${ }^{59}$ Ibid., p. 168.

${ }^{60}$ Ibid., 102. For Proudhon's engagement with the ‘sorry comforters' see, ibid. pp. 86-202.
} 
diversity and difference, at all levels of society and of thought, are central to order since they are the precondition of social dynamism and derived from the only tools available to change society - force. Moreover, force will also be the basis of any future revolutionary order. Without this basic anarchy no movement can take place in society and order and justice cannot change and emerge. Proudhon does not, however, see this openness and movement, the deep anarchy, as being legitimate within our most immediate social group: the family. This is again an instance of a first-order contradiction in Proudhon's thought and I will now discuss it in order to continue my immanent critique of his work.

\section{The Family and the Right of Force}

Proudhon takes the family to be a micro-social example of the right of force. He argues that “[l]a prépondérance du mari sur la femme, du père sur l'enfant, se résout dans le droit du plus fort. Pourquoi le nier? Pourquoi, hommes, en rougirions-nous? Pourquoi, femmes, en feriez-vous un texte de plaintes?” ${ }^{61}$ The answer is simple, if it is only a right of force that sanctifies it then it is brute materiality and not to be accepted unless it conforms with other rights and is legitimised and tacitly acceded to. If this is not the case, then women can and ought rightly to reject the brute right. When it comes to the family however, Proudhon's partiality is clearly inconsistent with his broader theory and we can use it to better explain and develop his ideas. Proudhon argues thus:

Dans une âme maîtresse d'elle-même, dans une société bien ordonnée, les forces ne luttant un moment que pour se reconnoître, se contrôller, se confirmer et se classer. Comme dans la famille la puissance paternelle a pour contrepoids l'amour, qui souvent fait pencher la balance en faveur du plus faible; ainsi dans la cité, les forces corporatives se balancent, et, par leur juste équilibre, produisent la félicité générale. L’opposition des forces a donc pour fin leur harmonie. A cet égard, la destination des États sur le globe n’est pas autre que celle des citoyens d'une même ville, ou des provinces d'un même État. Tout antagonisme dans lequel les forces, au lieu de se mettre en

\footnotetext{
${ }^{61}$ Ibid., p. 141.
} 
équilibre, s'entre-détruisent, n’est plus de la guerre, c'est une subversion, une anomalie. $^{62}$

Proudhon's paternalism is precisely that - a state of familial domination. The question is, why is it that family relations ought to remain paternalistic but all other social relations can be changed? There is no logical response to this question and Proudhon resolves it by claiming no more than that women are naturally inferior. Given that Proudhon is wrong here, there is no actual reason why social and familial relations should not be overturned to be more equitable. The family is a key locus of abuse for millions of women and children and society supports men because men constitute the key forces in society. Women are more likely to be killed by their husbands than anyone else and domestic homicide and violence constitutes nearly three quarters of all murder and violent assault. $^{63}$ There is nothing morally defensible about what is effectively a deontological commitment to paternalism in the family and Proudhon ought to have realised his contradiction here, not least because his theory of justice abrogates absolutes and the enforcement of social hierarchies. The key ought to be, as Proudhon's theory would lead us to argue, a balance between the evolving capacities of children and the autonomy and force of both parents within a wider social context.

The very fact that this critical argument can be made using Proudhon's thought shows how deeply sexism ran through the nineteenth century and how oblivious he was to the potential to develop his own argument. His position was a defence of the family against the Saint-Simonians and Fourierists, but it could just as easily have been made like this. However, that would probably have entailed the concession that all social groups, families included, break down, change and evolve. Sexism, however, is based on prejudice and is both immoral and unjust. Only a century of ongoing struggles, often quite violent, have slowly changed attitudes.

\footnotetext{
62 Ibid., p. 143.

${ }^{63}$ See, for example, Krug et al [2002].
} 


\section{Book III: The Forms, or the Material Reality of War}

Proudhon argued that, as with the relationship between law and society, the laws of war are immanent to it and are defined by war's object, which, he argues, has historically been assimilation, secession, or control. ${ }^{64}$ I begin this exegesis of Proudhon's approach to the reality of war with a discussion of the immanence of the rules of combat because Proudhon argues that the contravention of the rules of war is endemic to war and thereby taints its results. Thus while war is justice-making, it is in fact a flawed and tainted justice. The spell of war's ideal is thus consistently broken by its brute materiality. We see that Proudhon has developed a conception of the relationship between individual and society, between law and force; here he is concerned to outline the relationship between ideas and materiality. I will highlight Proudhon's use of the duel as the most appropriate analogy with the evolution of warfare. This analogy undermines any progressivist, or historicist readings of Proudhon's work. I conclude by assessing Proudhon's discussion of rape and other war-time atrocities to continue the immanent feminist critique of his work.

\section{The Immanence and Contravention of the Laws of War}

In the morally important and defensible absence of an overarching and transcendent force, the rules of war, like those of society, are immanent to it. They change and vary according to the internal composition and needs of societies and their adversaries, and the nature of the battles they engage in. The rules set out in the European tradition of Just War Theory are putative, negative or restrictive and are wholly conventions which have changed with the times and are largely religious and transcendental in character. What Proudhon's approach suggests is that no laws are transcendent if we take society to have evolved over time, and that the rules of war (and of society) simply reflect and emerge from the conflict between individuals and groups.

\footnotetext{
${ }^{64}$ Proudhon argues earlier in the book [153-155] that religious conflict or incompatibility is also a legitimate cause of war.
} 
Ces règles ou formes de la procédure guerrière n'ont rien d'arbitraire: elles découlent naturellement de la notion même de la guerre, de sa nature et de son objet. Leur violation constitue pour l'infracteur un crime, susceptible d'un châtiment sévère, s’il est vaincu; dont le résultat sera d'amoindrir, quelquefois d'annuler la victoire, dans tous les cas d'infecter le nouvel ordre de choses, s'il est vainqueur. ${ }^{65}$

While right of force is the foundational law of war, since it is the one from which all the others emerge, it is still open to critique. The type of force used is directly related to the material resources, technological advancement, and ideational restrictions of a society, and critique will itself emerge from some social context. What we need to know is why, therefore, war has escalated in destructiveness over time, and why the laws of war and pacifism as a novel social critique have repeatedly failed to rein states in.

Proudhon argued that any emergent laws of war can only be as binding and restrictive as all other conventions, which is to say they are as binding as we hold them to be or are forced to hold them. Recognising that "[u]ne infraction au droit de la guerre en amène une autre”66, and will also lead to a deterioration in the morality of war over time, the conventions against poisoning water supplies, exterminating entire villages, and others aimed at "softening" war have arisen out of the respect for the enemy and the need for this mutual respect to exist in order to validate the results of the victory and to infuse the juridical aspect of war-waging with some legitimacy.

The use and control of resources and the developments in the technological tools of war change the ways in which war and the use of force is realised over time. Since this inevitably gives rise to new and more atrocious forms of killing, it also changes the ways in which war is rationalised, which will itself be influenced by new ways of rationalising what we can and cannot do as a result of the new technology. As I discussed in chapters one and two, military industrialisation and the rise of a particular type of rationalist utilitarianism were the key forces changing military conventions at that time, and these

\footnotetext{
${ }^{65}$ Proudhon [1998a], p. 223.

${ }^{66}$ Ibid., p. 267.
} 
worried Proudhon immensely, while, as McNeill has argued, most others remained largely oblivious to these changes. While their presence is no guarantee of peace, the absence of universal codes of moral and legal conduct in the international system produced a permissive context within which states exercised their right of force. As they became more authoritarian and less accountable, and the means of war more centralised, problems merely compounded one another. This social ontology is central to explaining how, with the advent of industrial-strength weaponry and the materialist and rationalist utilitarianism of the nineteenth century, war began to lose its shine, and pacifism and a secular approach to the laws of war based on principles like sovereignty, began to arise.

Here Proudhon's discussion of the effects of modern artillery stands in stark contrast to his discussion of the ideals of war in books one and two. How can we base right on indiscriminate killing, he asks? How can war be heroic if artillery renders death more of a certainty than a risk? Proudhon argued that arming the French infantry with revolvers would enfeeble them morally and put the soldier "hors du combat". 67 "En un mot, le matérialisme de la bataille s'est accru avec la civilisation, le contraire de ce qui aurait dû arriver."68 Civilization ought to represent the pinnacle of human moral achievement, but the industrialisation of warfare has taken us in the opposite direction. While it is clearly not unprecedented for a superior force to win a battle, it is the sheer indiscriminate killing brought about by artillery that portends the end of the decisive battlefield duel and the opportunity to prove one's valour in war. "La guerre, en un mot, s'industrialise de plus en plus"69 and now "il a été impossible de purger le duel entre États des horreurs qui le déshonorent. ${ }^{, 70}$

With the state increasingly monopolising the use of force in society and against other societies, new doctrines of right were needed to justify the slaughter this centralisation and industrialisation was bringing about. Proudhon argued for the democratisation of the military as the only way to ensure the valour and pride in the military enterprise and to

${ }^{67}$ Ibid., p. 257.

${ }^{68}$ Ibid., p. 280.

${ }^{69}$ Ibid., p. 163.

${ }^{70}$ Ibid., p. 231. 
counterbalance the military elite with the wishes of the lower ranks, ${ }^{71}$ but the state did not. Cast against this background the following assertion of the veracity of war is a little strong:

Quiconque étudie avec un peu d'attention l'histoire de la formation du développement et de la dissolution des États, s’apperçoit bientôt qu'en moyenne, et à ne juger les événements que sur l'ensemble, ce qui est arrivé devait arriver, et qu'au total, la société etant donnée avec ses lois constitutives et évolutives, la guerre a fait justice. ${ }^{72}$

But if we see how the Revolutionary wars and battles for self-determination have been epochal for communities throughout history the impression we get of the veracity of war is less problematic. From 1815 to 1945, the laws of war have emerged from the conduct of war by societies, which have themselves then been shaped and constrained by the ensuing laws and treaties. The history is one of failure and escalation, industrialisation and genocide with the parallel evolution of ever grander universal declarations of right. This stands in stark contrast to the evolution of the duel and is remarkably evocative in Proudhon's analysis.

\section{The Duel}

Proudhon compares the evolution of the duel with that of war, particularly in relation to the rules of the contest, and he was particularly well qualified to do so despite never having been a soldier (which actually very rarely stops anyone from writing about war). In 1848 Proudhon fought a duel. The cause of the duel, like the immediate or surface cause of many wars, was a personal insult. Félix Pyat verbally abused him, calling him an "abominable pig” during a confrontation in the corridors of the French Assembly. In retaliation Proudhon punched him in the face. Pyat then challenged him to a duel. The Parisian workers and the police attempted to stop it but Proudhon evaded both, believing he had to defend his honour. Two shots were fired but no one was hurt. Afterwards he

\footnotetext{
${ }^{71}$ Ibid., p. 286.

${ }^{72}$ Ibid., p. 312 (emphasis added)
} 
denounced the tradition as a "ridiculous comedy" and, when challenged to a second duel within a matter of weeks, he refused believing it to be a plot by the Jacobins to oust him from parliament for good. ${ }^{73}$

This story contains in microcosm the features of social conflict Proudhon would have us recognise: force, power, right, contest and so on. Proudhon also argued that "une contradiction perpétuelle [existe] entre la théorie du droit de la force et son application,”74 a realisation he only came to afterwards. But what is most striking perhaps is the sociological conclusions he drew from it. As Proudhon argues,

La concience universelle, plus puissante que la police des rois et la sagesse des juristes, le dit [que la guerre et le duel sont justes]; et c'est parce que la conscience universelle le dit, que des règles imposées au duel, et que le meurtre commis par le duelliste est excusable. ${ }^{75}$

But where did the laws of the duel come from? Proudhon argues that the progressive accentuation of the personal valour associated with the duel developed throughout its evolution from surrogate riders on horseback or proxy warfare, to a two-man shoot-out in shirtsleeves. The veracity of the contest emerges from the purposive human reinforcing of the sanctity and honour of the contest, through active resort to it. Over time the element of personal risk and the immediacy of the contest is accentuated to cement the solemnity of the contest, a contest which decides right by force where no other party can so legislate. In the duel, a victory won by fraud annuls it. Honour remains with the defeated and social pressures effectively invalidated the contest through ostracism.

This is almost the complete opposite of the processes involved in the industrialisation of the instruments and the distancing of combatants in modern warfare. Nevertheless, conventions arise in war from mutual respect, fear of reprisal, and innumerable other factors. However, Proudhon argues that the duel between nations is on the decline. He argues that Napoleon's campaigns were perhaps the last test of civic élan and laments its

\footnotetext{
${ }^{73}$ See Vincent [1984], pp. 187-188. cf. Woodcock [1956], p. 141.

${ }^{74}$ Ibid., p. 202.

${ }^{75}$ Proudhon [1998a], pp. 223-224.
} 
passing; that decisive battle that tests the moral strength and power of a nation, epitomising its valour and heroism through its military is gone. ${ }^{76}$

In the contemporary environment, as much as at Proudhon's time, only self-restraint can ensure this social duel is morally valuable and thus its results veridical. One "infraction au droit de la guerre en amène une autre"77 and so on until escalation obliterates life on earth. Written conventions protecting prisoners and non-combatants allow all to know the terms of morally acceptable behaviour in war, but the strict observation of these terms is the exception. ${ }^{78}$ As war industrialised during the mid-nineteenth century, what was already complicated enough became compounded by the ability to kill at distance, or conversely, without ever knowing who had killed you. The reciprocal nature of war was illustrated by the decimation it caused, not the right it enforced. The valour and muscular heroism that had been such an important part of the rationalisation of warfare vanished.

C’est surtout de l'invention de la poudre à canon et de la prépondérance de plus en plus décisive de l'arme à feu sur l'arme blanche que date ce que j'appellerai la dépravation des batailles. Mais, chose à noter, l'emploi de l'artillerie, après avoir suggéré l'idée de ces chocs écrasants, paraît tendre aujourd'hui, par le perfectionnement des armes, à rendre la rencontre des masses impossibles. $^{79}$

This analogy with the duel allows us to see how the relationship between the theory and the practice of the right of force is antinomic and suggests no necessary progress. It is because of this that systems of morality have evolved along with the evolution of warfare and the rationalisation of its use, while barbarity has also increased through technology and distance killing. It is also in this context that we ought to read the rise of pacifism and the hubris of nineteenth and twentieth century industrialists and military strategists. Proudhon, however, thought pacifism was a sign of the emasculation of society and we

\footnotetext{
${ }^{76}$ Ibid., p. 279.

${ }^{77}$ Ibid., p. 267.

${ }^{78}$ cf. Muller [1990]

${ }^{79}$ Proudhon [1998a], p. 283.
} 
can now say unequivocally that he was wrong to do so. ${ }^{80}$ Nevertheless, Proudhon's contribution here is to show the immanence of rules to human social action. Again, the aim is to 'pierce the divine', and to account for the source and sanction of moral rules in terms other than the materiality of state violence.

\section{Rape and War}

A stark example of how moral norms evolve can be seen in Proudhon's discussion of rape in war. Proudhon was well aware that soldiers were not natural enemies and he argued that the group ought to be kept separate analytically and normatively from the individual. ${ }^{81}$ Still, in Proudhon's view group psychology and the structures within which they operate are permissive of what would usually be unacceptable. A striking and sickening example of this in Proudhon's analysis is his rationalisation of rape during war. Proudhon argues that the rights of force and the rights of war bestow on the conqueror a right to the prize of that conquest. Following the Book of Exodus (22:21) Proudhon argues that women become the property of the victor and rape cannot be considered a

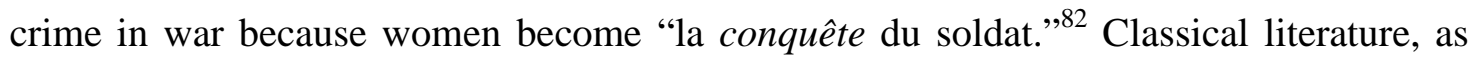
well as the Bible, is no less replete with such claims and Proudhon cites them liberally. Conquest is conquest, he argues, but "Il y a viol et viol"83 and wartime norms are permissive in a way in which they are not usually.

Again this is a first order contradiction in his thinking which only holds if women are somehow outside his moral ontology and have no defensible moral autonomy. He argues that the demise in the incidence of rape has less to do with the development of the moral sensibilities of the military than it has to do with the changing character of warfare, and the Christian demand for abstinence. But this candid discussion is utterly unthinkable today precisely because we respect the inherent dignity of women, a respect that has developed with the empowerment of women in the last half-century at least but remains

\footnotetext{
${ }^{80}$ It is also worth noting that state prohibition against duelling arose at precisely the time that the state was consolidating its total juridical authority in society, thus taking the capacity to decide on matters of life and death out of the hands of private individuals cf. Muller [1990]

${ }^{81}$ Proudhon [1998a], p. 289.

${ }^{82}$ Ibid., p. 272.

${ }^{83}$ Ibid., p. 271.
} 
woefully behind where it ought to be - particularly in war, which is but a reflection of society.

Strangely, Proudhon accepts that the right to the lives of the vanquished is the mythical misapplication of the right of force based on a conflation of the group with the individual (killing one is not the same as killing them all). All individuals are sacred for Proudhon and he sees that rape is one of "les faits de guerre le plus révoltants" ${ }^{84}$ It is for this reason that his ambivalence about it is evidence of a first-order contradiction in his thinking. The full empowerment of women in civil, economic and political terms, as recognition of the fundamental equality between men and women, is the only solution to this. Society must institute stronger sanctions, inevitably based on some sort of force, against the mistreatment of women. The question is how and who ought to do it, and answers were being suggested by the feminists of the period but were increasingly statist in orientation and failed to bring about the changes demanded. It was clear that women ought to do it for themselves, but how was another matter entirely. Proudhon never engaged with the latter question because he would not counter the former. Modern anarcho-feminism has its own answers, but it impossible to do them any justice here. ${ }^{85}$

\section{Book IV: Pauperism and Militarism: The Economic Causes of War}

By the time we get to Book IV Proudhon has radically altered our ontology of war and by so doing allows us to see it in another way. We understand the role of both moral and material forces in its evolution and we have some idea of the moral and political causes of war, but we do not have a theory of what causes war. Proudhon argues that to grasp this aspect of war one must turn to political economy. The theory he develops posits that "ruptures in the economic equilibrium" are the fundamental cause of war and through historical analysis he developed an economic history of warfare from antiquity to the mid-nineteenth century, and speculates somewhat accurately about the immediate future. I will divide this section into four, beginning with a discussion of causes and his humanist ontology. I then discuss the evolution of militarism, mercantilism, colonialism and total

\footnotetext{
${ }^{84}$ Ibid., p. 272.

${ }^{85}$ See, for example, Dark Star Collective [2002].
} 
war. I then turn to his debunking of the myth of industrialism and pacification and his comments about the emancipation of the working class, before I ask "where are the women" in this discussion. The absence of women in this book, in a discussion of the economy, is significant given who sustained Proudhon materially and emotionally. I refer of course to his wife. Proudhon is blind to the structural economic exploitation sustained by patriarchy, and makes nothing of it.

\section{Pauperism and the Rupture of the Economic Equilibrium}

Contextualising the theory of political economy Proudhon uses here would necessitate another thesis. Needless to say he was one of the fathers of the modern socialist movement. Proudhon's What is Property? was described at the time as "the first resolute, pitiless, and at the same time scientific investigation [...of] private property" and "as important for modern political economy as Sieyes’s work Qu'est-ce que le tiers état? for modern politics”, by Marx. ${ }^{86}$ In La Guerre et la Paix political economy is but one of four factors contributing to the explanation of war and peace - moral change, industrialisation, and law being the other three. However, political economy underpins the other three.

Proudhon's argues that there are two general types of causes of war. The first, commonor-garden variety, are the political or religious causes, as well as jealousies pride, prestige and so on. The second type, the deeper causes of war, are those which animate the first type, set the context for them and are permissive of them: these are wholly economic. In this Proudhon agrees with Grotius that the key cause of war is the defence of oneself and one's own. But why, apart from the sheer individualist materiality of it, would this cause war? What are the deeper philosophical reasons that explain how property relations cause different forms of conflict over time? Proudhon answers that, at root, the need to feed one's self is the basic animator of life. Remove that capacity and conflict for resources is just around the corner. In short, the principle cause of war “[c]'est le manque de subsistences; en style plus relevé, c'est la RUPTURE DE L'EQUILIBRE ÉCONOMIQUE. ${ }^{87}$ Proudhon historicises this theory in the following way.

\footnotetext{
${ }^{86}$ McLellan [1977], p. 132.

${ }^{87}$ Proudhon [1988b], p. 16.
} 
Our natural, human condition, Proudhon argues, is one of poverty. This is composed of three interrelated economic "laws". First, we need to consume. Second, unlike animals we need to produce in order to consume. Production or work is thus the second law of poverty. The third law is poverty. This law represents the natural balance between production and consumption. Too much of the former is useless and too little of the latter is fatal. The precise nature of the balance between the two is related to access, ability, cooperation and force. This is also relative to the subject's position in society. Clearly if one lives in a castle one's income will need to be relatively higher than if one lives at subsistence level, but once, or if, the income stream runs out, the former has far more to lose than the latter. Industrialisation, Proudhon argues, cannot alleviate our natural predicament; it merely obscures it (and with hindsight has brought us to the brink of ecological collapse and taken us through two world wars). As such, the antinomy between production and consumption is permanent, but it is also historically and contextually specific. Human consumption is dependent upon a number of factors, not least the land's ability to yeild food. Thus for Proudhon, quite apart from the sociopolitical causes of the rupture, which he discusses at length, the slightest disruption of the ecological environment through drought, flooding and so on "produit du désordre"88 and this is as true for plants and animals as it is for humans.

As a result, Proudhon argues that this condition of poverty places an immanent moral law upon social and individual activity. True to his ideas about restraint and virtue, this peasant morality advocates “[t]empérance, frugalité, le pain quotidien obtenu par un labeur quotidien, [parce que] la misère [est] prompte à punir la gourmandise et la paresse" ${ }^{89}$ The happiest are those who "sait le mieux être pauvre" which ought not to be confused, as it was, with a call for religious fatalism regarding one's poverty. ${ }^{90}$ Confusing those readers who held out for the promise that industrialisation would eradicate famine, war and other human ills and replace it with plenty and the abolition of work, Proudhon claimed that the most avaricious and luxurious nations are those most immanently in decline. Proudhon argues that the most stable societies are agrarian and self-sufficient,

\footnotetext{
${ }^{88}$ Ibid., p. 18.

${ }^{89}$ Ibid., p. 20.

${ }^{90}$ Ibid., p. 27.
} 
but prone to natural shocks. Because, he argues, wealth production had become "une maxime de morale et de gouvernement"91 we ought to expect problems.

This encroaching condition of pauperism (wherein the economic law of poverty is ruptured) is one in which societies, either through elements of parasitism, sloth, exploitation, natural disaster, invasion or expropriation, cannot produce enough to survive as a whole. Pauperism is as immanent to the wealthy as it is to the poor but the former have greater means to avoid it than the latter and these means are often directly related to the expropriation of the poor through force or wage-slavery. Industrialisation, controlled as it is by private interest, entrenches this imbalance of force and subsistence. State power, parasitical upon both private interest and social surplus, further entrenches this imbalance, but does so by military as opposed to economic force and rationalises it according to the doctrines outlined in the previous chapter (amongst others). These doctrines, which also stipulate the principles of distributive justice, themselves emerge and evolve over time and are governed by what people believe to be their just desserts based on prevailing modes of rationalisation in a given society. In extreme conditions all norms become irrelevant. As Proudhon notes, “[p]our son pain quotidien le peuple sacrifie sa religion et ses dieux."92 This basic theory was developed by Proudhon into the following economic history of warfare.

\section{Militarism, Mercantilism and Colonialism}

In keeping with his Comtean three-stage division of history, Proudhon distinguishes between the religious, the metaphysical and the scientific periods in the history of the causes of warfare. In the earliest religious stage, war was synonymous with pillage and there was a right of pillage based on the force with which it was carried out, rationalised according to theological principles, and sanctified through rituals that gave meaning to necessity. The Bible is replete with examples of economic deprivation causing tribes to migrate and thus come into conflict with others, or hardship justifying the extermination of opposing tribes. There are stories of how all newborn babies had to be thrown into the

\footnotetext{
${ }^{91}$ Ibid., p. 31.

${ }^{92}$ Ibid., p. 43.
} 
river to avoid wider social starvation; actions that were rationalised by reference to the gods since no other means of so-rationalising their predicament was available.

In the times of Homer and the Greek city-state system, also here considered the theological era, piracy and pillage were well-regarded precisely because the leaders were the most adept at it and their actions sanctified by the gods who were also in constant battle with one another. The establishment of inland cities was designed to avoid seaborne attacks on dwellings which in the process consolidated a particular form of patrician class that controlled the defence of the state and the economic resources necessary for their survival and consequently the survival of the city-state system itself.

This initial form of social organisation is quickly replicated and the key continuity for Proudhon is the entrenchment of militarism. This is ultimately "la physiologie du paupérisme et son influence sur les gouvernements que je retrace."93 Militarism is the control of the economy to provide for primarily military ends. And these ends are necessary to not only protect state power internally and externally, but also to ensure the continuance of a steady stream of income to the state.

Il y a donc toujours militarisme au dedans et tendance à la conquête au dehors; seulement la guerre [...] réalise ses bénéfices sous une autre forme. De même qu'aux siècles d'Alexandre et de César le pillage heroïque s’etait transformé en conquête, de même la conquête tend à se transformer à son tour en gouvernementalisme. ${ }^{94}$

Mercantilism and colonialism are the most obvious examples of this militarism from the mid-fifteenth century though they both have historical precedent. Proudhon's opposition to colonialism was discussed in chapter one. Here it is worth expanding upon it to illustrate that the economic motive for the forced control of a foreign population for the needs of the centre mirrors this economic history. Hobbes, Locke and Grotius are the moral revolutionaries of this philosophical or metaphysical period, advocating and

\footnotetext{
93 Ibid., p. 75.

${ }^{94}$ Ibid., p. 112 (emphasis added).
} 
entrenching systems of thought that justify colonialism and expropriation by reformulating the ethics of private property, and stating the godless inferiority of the peoples of the new world based on rational arguments. As Richard Tuck has shown, claims to rationality notwithstanding, Hobbes had economic shares in the colonial projects in the New World and thus a vested interest in developing theories that supported colonialism. ${ }^{95}$

Taking Italy as his example, Proudhon argues that while national self-determination may be the obvious cause of the conflict, behind that Proudhon recognises the French left's argument for a united Italy as motivated by a desire to disenfranchise the Papacy and the Divine Right monarchies of Naples and Tuscany. Popular support for Napoleon III's expedition was derived less from a sense of national pride than of a desire to better their economic situation. Napoleon III's championing of both the social and the national cause was a pretext for his need to both cement his Imperial grandeur and also to divert attention from the dire economic situation of France during the second empire and his need to keep the left on side. The science of political economy provides the tools to illustrate the economic causes of war and unmask the pretensions of states and their appologists.

\section{Where are the Women? ${ }^{96}$}

Women are conspicuous in this book by their absence. But it is vital to point out that Proudhon was only able to produce this discussion of war because his wife bore the domestic economic burden. In this regard, his ability to produce was no less premised on a need to ensure his predominance in the familial economic equilibrium and to rationalise his wife's permanent subjugation. It is here worth saying a few words about his wife's testing years during the exile in order to illustrate this point more clearly.

\footnotetext{
95 Tuck [2001], p. 128. Hobbes was a landowner in Virginia and his “principal employer, Lord Cavendish, who had been involved in the Virginia Company for at least ten years, transferred one of his shares of land there to Hobbes, who was at the same time acting as his secretary.

${ }^{96}$ Enloe [2000].
} 
Having recovered from scarlet fever, Euphraise grew sick of being the housewife in a country she found not to her liking. She was denied participation in the discussions Proudhon would have with his friends and visitors (at this time Tolstoy was among them) and she was compelled by their mutual hardship to make and sell embroidery to pay for the children's school fees while Proudhon wrote day and night. When Proudhon fell ill at the end of 1861, Euphraise cared for him despite suffering rheumatism herself. In September 1862 Proudhon finally left Brussels to return from exile and "with a rather unimaginative disregard for their mental tranquillity, left Euphraise and his children at Ixelles." ${ }^{\text {97 }}$ None of the literature I am reviewing here would have been possible without Euphraise's unpaid labour, but Proudhon simply does not counter the argument that this is in any way significant for his own theory.

Proudhon did remark in a letter to his friend Victor Pilhes that "[m]y wife rebels in her own manner, and in the things that interest her you will one day see that my paternal and conjugal authority has been demolished. Ah, how quickly I would be consoled if I saw the good people of Paris animated by such sentiments."98 He also educated his daughters in such a way that they would not become docile ladies but would be independent women in their own right. But this does not change the fact that Proudhon does not apply his analysis of the economic causes of conflict to the one that clearly existed between the sexes. Thankfully the resolution of this conflict has seen some progress in spite of Proudhon, and has involved ending the tradition of trading dowries, changing the legal status of women from male property to citizens, and further developing political, social and economic enfranchisement.

\section{Conclusion: Book V: The Transformation of War}

In Book I Proudhon asked us to refocus our analysis onto the moral ontology of warfare and to look at war historically. This allowed him to approach the question of law from a humanist and historical perspective in Book II. Taking the right of force as central to any analysis of war he argued that we can see how moral norms have emerged and overlaid

\footnotetext{
${ }^{97}$ Woodcock [1956], 244.

${ }^{98}$ Cited in Ibid., p. 237.
} 
this brute fact of our social existence. In Book III he argued that change can be explained through the practice and rationalisation of warfare, as long as we see how warfare itself has changed, structured and has itself been structured, by wider social forces such as the state, industrialisation, capitalism and so on. Book IV sought to show that while war was the motor it was pauperism that was the cause and this is, like morality, immanent to our natural human condition. The first four books are a demonstration of how law, morality, change and progress, as well as decline, force and immorality are all consequences of human action. The solution to the problem of war must therefore be sought here too. Whereas for others, the human source of the solution would have to be rationally deduced principles of cooperation and order (pacifism or the categorical imperative), or the simple overwhelming preponderance of force in a society to mention but two examples, Proudhon believed that any change would have to come from the masses since it is their exploitation which explains the principal causes of war found. There is a clear symmetry here and Proudhon's theory is generally consistent - with the important exception of his sexism.

Thus if peace was to have its own, positive reality, defined in a way other than simply the absence of war, he had to discuss what this sort of peace would entail, what it would be like and how we might achieve it. Given that he sees war as a moral and historically virtuous exercise, peace also needed a positive and virtuous character that was immanent in the human condition. The positive peace he sought also had to encompass the novel historical conditions which he believed nineteenth-century France to be experiencing, and should be the natural development of these conditions as opposed to aiming towards what is effectively a transcendental utopia that would take exorbitant control to impose it. Thus peace would have to be generated by the people and sustained through an economic equilibrium and social justice. He argues that the working class need to realise their own political and economic capacity and he sees industry as pacifying since it allows the creative and destructive urge to be realised without war. Clearly this is a very masculine approach; one which grants women no place is social change. Bearing this in mind, we can question the universalist logic of the following statement. He argues that “[l]’humanité travailleuse est seule capable d’en finir avec la guerre, en créant l'équilibre 
économique, ce qui suppose une révolution radicale dans les idées et dans les mœurs."99 Proudhon does argue that universal suffrage will be the natural "successor" of war and the only way peace will reign is if it is the manifestation of "la conscience universelle". Proudhon's anarchistic impulses have receded into the background here. He continues:

Actuellement c'est la plèbe travailleuse qui tend à supplanter la bourgeoisie capitaliste, propriétaire et patentée, et qui fait son apparition par ces deux formules: Droit au travail et Suffrage universel. Nous ne sommes qu'au début de ce dernier mouvement. ${ }^{100}$

Thus, from this point the question is how to organise this new movement. He is clear, however, that it will be a political battle. In terms that turn Clausewitz's maxim on its head, Proudhon argues that "la politique, par son essence, par son droit, par toutes ses institutions, c'est la guerre.”101 But then Proudhon closes the work with the lines “L’HUMANITÉ NE VEUT PLUS LA GUERRE!"102 What can this mean? Given his views on the feminisation of society through its refusal of the martial impulse, and his views on politics as war, is he not guilty here of branding the whole of humanity as abominable anti-political feminists? This conclusion is inescapable given the amount of vitriol he directs towards pacifists and feminists in the work. It also reflects his awkward and clumsy attempts at the end of the work to position himself within the French left and global attitudes to war more generally. This was no easy time to walk a tightrope between pacifism and left-wing bellicosity and the tensions in the work reflect this social and intellectual context.

The rhetorical clumsiness of Book V is something of a disappointment. As Bourgeois argued, the two volumes never quite deliver on the ambitious scope of the work. Yet this is no reason to discard Proudhon's theory, simply because we can and should look elsewhere for his more developed solutions. In fact, for the next five years Proudhon turned his theory of the immanence of justice in social conflict and war to the

${ }^{99}$ Proudhon [1998b], p. 168.

${ }^{100}$ Ibid., p. 160.

${ }^{101}$ Ibid., p. 122.

102 Ibid., p. 189. 
international problems of his time - analysis I explained in some detail in chapter one. The international developments of the period, particularly Italian unification, influenced the solutions to the problems he poses here. These solutions also contain important developments to the theory of justice and war, in particular his theory of mutualism and federalism. It is to these two that I now turn in the following, final chapter. 


\section{Chapter 6}

\section{Justice and Order in Anarchy}

As man seeks justice in equality, so society seeks order in anarchy. ${ }^{1}$

\section{Introduction}

Chapter four set out Proudhon's opposition to the Kantian rationalist individualism, and also Comtean positivism, through a discussion of the concept of immanence as applied to justice. Chapter five turned to war, what we might call Proudhon's case study, to illustrate how his immanent theory of justice was able to explain and be accounted for in a theory of change. In this chapter Rousseau and the Jacobin communists take centre stage, as I discuss Proudhon's normative theories of federalism and mutualism. I show how Proudhon's critique of the doctrines of national unity, discussed in detail in chapter one, can also be read as a critique of revolutionary Jacobin communism and its tactics.

Thus the unifying object of attack is statism. Proudhon uses his theory of social justice, and his theory of social order and change, to develop a theory of normative political economy, which, he hoped, would bring peace to Europe by radically deepening and federating democracy domestically, and federating European states. This, he thought, would bring peace to Europe, but two things stood in the way of such a democratic and constitutional peace: states, and the emergence of "la feodalité industrielle". ${ }^{2}$ Both were vital to imperialism and militarism. It is in this context that we ought to read Proudhon's mature anarchism. What I will show is that for Proudhon, anarchism now meant the progressive restraining of states through deepened democratic institutions in the economy

\footnotetext{
${ }^{1}$ Proudhon [1994], p. 209.

${ }^{2}$ Proudhon [1867], pp. 36, 82.
} 
as well as the in the polity, which he thought would keep states to heel. This was the essence of his mutualism. Federalism was designed to hold states, communities, towns, regions, industries and every other conceivable group that so wished to unite, in mutual bonds of reciprocity with one another. If states were actually to become the servants of the people, Proudhon believed they would federate. The problem, as the opening quote of chapter one illustrated, was that things were not going Proudhon's way.

This chapter thus links to the first by bringing the analysis back to where we began. What I will show is that Proudhon's normative federalist project was intimately related to, and therefore ought to be seen to be fully integrated with, his work as a whole. Having outlined his "revolutionary ontology" in chapter four and his historical analysis of the immanence of justice in chapter five, my aim here is to provide the normative and institutional details of Proudhon's alternative to the statism, industrial feudalism and militarism. Chronologically, Proudhon's alternative is first constitutional, then geopolitical and federal or confederalist, and finally it is economic. In reality, each is intimately interlinked, as I will show. I will, however, follow this chronological order here.

The analysis of this chapter is taken from the political works which immediately followed La Guerre et la Paix. I do not engage with the second two parts of Du Principe Fédératif, nor France et Rhin, La Fédération et l'Unité en Italie, or Nouvelles Observations sur l'Unité Italienne, since these were discussed in some detail in the first chapter. This chapter engages with the first part of Du Principe Fédératif, Si les Traités de 1815 ont cessé d'exister, and De la Capacité Politique des Classes Ouvrières. My claim is that the unifying theme of these works is Proudhon's battle with the legacy of Rousseau in the Jacobin left.

The chapter is structured in the following way. First, I provide a brief history of the two key texts that form the backbone of this chapter. I will show that these were selfconscious reflections on the ambiguities and unanswered questions of the works that preceded them. In the second part, I will illustrate how the secondary literature has tended to approach these works as isolated texts, and again I argue that my approach helps cut 
through some of the controversies generated by taking them out of context. Read alone these texts can mean a number of things, read together and in conjunction with the texts that preceded them, their meaning and aim are less open to interpretation. Read in the context of the emergence of a newly self-conscious working class in France, the need for European international stability and the rise of statism and militarism, in my view the texts take on even greater significance. I will substantiate these claims further in the conclusion to the chapter and in the conclusion to the thesis that follows.

In the second part of the chapter, I turn to the first part of Proudhon's mature normative theory. The key text here is Du Principe Fédératif. Having spent the previous three years writing about world politics, it becomes obvious to Proudhon that any new world order must take both the structure of the European balance of power and the federalist projects of perpetual peace seriously. Building on the analysis I provided in the previous chapter, I will show that Proudhon saw the balance of power to be deeply embedded in society, right up from the family to interstate relations and that these relations ought to be democratised and federated (with the exception of the patriarchal family). This stands in direct contradiction with the alienation demanded by Rousseau, but does so by trying to better realise the idealism that underpinned Rousseau's thought. To do this, Proudhon turns to what we might now understand as political theory, but which was more a combination of his philosophy of history, a theory of law and a theory of political order. Their connections were typical of his period and the richness of the theory that emerges has often been overlooked. Proudhon is clear that if social order is to be guaranteed in Europe then the international balance of power must be embedded and deepened; embedded through treaties and deepened through the granting of rights of autonomy and "self-governance" (Proudhon uses the English here) to plural European social forces but not to women.

Following on from the turn to political economy in the previous chapter, in the final part of the chapter I show that Proudhon also argues that the European balance of power must be embedded in and realised through the new political capacity of the working class. In this section I will show that Proudhon's approach features a far more plural ontology of the working class movement because his understanding of consciousness and capacity are 
more varied than the concept of class consciousness was to become. What I will argue in the final part of the chapter is that Proudhon's later mutualism discussed in detail in De la Capacité ought to be understood as a development of his ideas about morality and the economy that were left underdeveloped in De la Justice and La Guerre et la Paix. The discussion of mutualism here has three main dimensions: the international, the economic and the socio-political. Proudhon argues that each of these levels of social reality works according to the same logic and can therefore be regulated by a single, if loose principle of mutualism. To realise this economy and social justice, the principle of federation - the political corollary of mutualism - must also be instituted in politics. Outlining what he means by this and how it is likely to come about will be the principal aim of this chapter. I hope to show how and why Proudhon believed that justice and order were both possible in anarchy, or why anarchism was, and remains, not only possible, but necessary.

\section{A Brief History of the Texts and the Secondary Literature}

The final stage in Proudhon's intellectual development began in 1862. At this time he had been in Brussels for nearly three years, refusing to take advantage of a pardon issued by Napoleon III to most if not all the exiled French revolutionaries. He then published the two articles that would later make up Fédération et l'Unité en Italie. In them, he argued that for the democrats to allow the creation of a Piedmontese empire to go unchallenged in the Italian peninsula would be tantamount to giving carte blanche for the French annexation of Belgium. ${ }^{3}$ This argument was spun by the local media to imply that Proudhon had actually called for Belgium's annexation by France and a mob was rallied in front of his house demanding that he leave the country. Prudently, Proudhon now decided the time was right to take advantage of his amnesty and returned to Paris. Here he decided to explain himself fully by responding to the claims of the Belgian nationalists. It soon became clear to him that the answers to the Italian conundrum were not available in his earlier writings on war and so he decided to pen yet another piece to

\footnotetext{
${ }^{3}$ Proudhon [1862], p. 55.
} 
explain his normative position on the future of Europe. Du Principe Fédératif was the result. ${ }^{4}$

This work has been described as his greatest work by many early twentieth century luminaries including Harold Laski, David Mitrany and Justice Oliver Wendell Holmes, ${ }^{5}$ but today, Du Principe Fédératif interests specialists in federalist theory only, and even here often only in passing. ${ }^{6}$ Nevertheless, it remains the only work of the period covered by this thesis to be translated into English. ${ }^{7}$ Richard Vernon's translation deserves some attention in order to understand why a re-reading of this work is necessary in the light of the context provided in the previous chapters.

Vernon's stated aim was to contribute to twentieth-century federalist theory and he pitched the work as a classical example of French and anarchist political theory in its own right. This restricted the English-language appreciation of the work in important ways. Vernon argued, following George Woodcock, that only the first part of the work was of lasting importance to contemporary readers - assuming the theory, rather than the history of the work, to have lasting longevity. As such, only the first 84 of 242 pages were translated into English. This truncation narrows the contribution of the work unnecessarily. Moreover, Vernon's introduction to the work is neither contextualised in terms of the books that came before it, nor in terms of the debates the latter two thirds of the work engage with. Thus, in presenting the analytical theory, we lose what the theory was actually for.

Given the context I have provided in the preceding five chapters, it should come as no surprise that I argue that this is unfortunate. In losing the context we lose the significance of the work. The historical context of this work, and its broader importance in Proudhon's oeuvre, illustrates how close European politics was to totalitarianism in the midnineteenth century, and how prescient Proudhon was in terms of his critique and the timely significance of his federalist alternative. Moreover, and perhaps more modestly,

\footnotetext{
${ }^{4}$ This story is recounted in the preface to Du Principe Fédératif. See Proudhon [1867], pp. 1-8

${ }^{5}$ This will be discussed further in the conclusion.

${ }^{6}$ See Nelson [1975] for the only extended comparative approach to Proudhon's federalism.

${ }^{7}$ Vernon [1979].
} 
since this context is largely the source of a text's meaning and best allow us to ascertain Proudhon's intentions, Vernon's introduction and translation hinder rather than helps our understanding of Proudhon's theory. It also contributes to Proudhon's mythological legacy by claiming that Proudhon's observation that the federal idea "n'a encore été présentée par personne"8 is a little "vain". ${ }^{9}$ In the final analysis, Vernon claims that Proudhon is not theoretically rigorous enough, not philosophically precise enough, and not consistent enough. Despite accepting that “a full-scale exploration of Proudhon's work” is still lacking, Vernon does not see this as a barrier to his own somewhat negative conclusions. ${ }^{10}$

Alan Ritter's analysis is far more problematic. Ritter argues that there is a fundamental shift from Proudhon's theory of mutualism, which he believes to be ineffective in the face of international threats to its survival, and federalism, which he sees as better but still "no improvement on existing arrangements". ${ }^{11}$ Ritter's methodology presents a "neoliberal"12 Proudhon that has coloured much subsequent analysis and fails to recognise that the most important articulation of Proudhon's theory of mutualism came after his theory of federalism, in De la Capacité Politique des Classes Ouvrières (1865). Despite many important observations, as an introduction to Proudhon's thought, Ritter's work is unhelpful, as I have consistently argued. This chapter will seek to redress this state of affairs by demonstrating the coherence, symmetry and plausibility of Proudhon's thinking based on the perceptiveness of his analysis of the ultimately fascist and bourgeois trajectory of French and European politics.

The history of De la Capacité Politique des Classes Ouvrières is somewhat different and has generated far less commentary. It was written in response to a request by Tolain, a Parisian worker who later headed the French delegation to the First International, ${ }^{13}$ and contained Proudhon's opinions on the recently published "Manifesto of the Sixty". This manifesto called for working class representation in the French Assembly on a quota

\footnotetext{
${ }^{8}$ Proudhon [1867a], p. 9.

${ }^{9}$ Vernon [1979], p. vii.

${ }^{10}$ Ibid., p. xliii.

${ }^{11}$ Ritter [1969], pp. 160, 144-146.

${ }^{12}$ Vincent [1984], p. 234.

${ }^{13}$ Ibid., p. 232.
} 
basis. Proudhon rejected the call for parliamentary representation, but was struck by the fact that this was the first truly working class expression of its own political will in the nineteenth century. De la Capacité responds directly to this and is a classic statement of French working class politics as a result.

Unfortunately, the presentation of the debates to which Proudhon was contributing have been narrowly interpreted for largely partisan purposes. Bernard Moss correctly reads the period under question as the flowering of the French labour movement. However, because of his Marxist approach to French labour history, he sees Proudhonism as having been antithetical to the true interests of the French working class. Proudhon's anarchism was "individualistic" and "incompatible" with the trade socialism that arose during this period. He sees the idea of a "Proudhonian labor movement" as a "myth"14 because of his presumed denunciation of “collectivist socialism”. The status of Moss' classic statement of French labour history no doubt goes at least some of the way towards explaining the reluctance of others to return to Proudhon's thought. However, as I will show, what Proudhon actually criticised was vanguardist social democracy, and more importantly the communist variety of collectivism which he believed denied the autonomy and liberty of the individual. Moss conflates all socialism with its Marxist variants, which is a mistake. It is true that Proudhon argued against strikes and political participation in the electoral process, but a full and fair examination of why remains absent in Moss' work - indeed, Moss cites from a total of six pages of Proudhon's works.

As Vincent has argued, De la Capacité "was to demonstrate to the workers that 'justice' could be a touchstone for social and political action, that this most elementary principle of morality could become the foundation of economic right and the pivot of new institutions." ${ }^{15}$ Vincent's analysis focuses on Proudhon's contribution to the evolution of French republican socialism and his narrative follows this route. I will now support Vincent's work by showing how De la Capacité and Du Principe Fédératif relate to international political issues and to Proudhon's international political theory.

\footnotetext{
${ }^{14}$ Moss [1976], p. 7, 6.

${ }^{15}$ Vincent [1984], p. 227.
} 


\section{Federalism and World Order}

La Guerre et la Paix, I have argued, was principally an exercise in the historical sociology of the interrelationship between law and war. The political theoretical aspect of De la Justice is relatively absent in that discussions of "collective force" and "collective reason”, while implicit, are relatively minimal given their centrality to his previous work. Moreover, the concept of the antinomy, used by Proudhon to conceptualise the nature of the cognitive and social process, also dropped out. But each of these concepts come right back to the forefront of Proudhon's analysis in Du Principe Fédératif. The use to which he put his concept of the antinomy, his epistemology and the basics of his ontology, are all clearly set out. I will focus on how Proudhon deploys the concept of the antinomy in his federalist theory. I then go on to show how this relates to his dynamic philosophical history of state formation. Taking the political antinomy as foundational, state formation as historical, and conflict to be ever-present, Proudhon proposes the principle of federation as a domestic solution, and then illustrates how it is already visible in the international system. I will develop the theoretical analysis of chapter one to illustrate how federalism links to his international theory as a whole. The purpose is to show how the international system needs to be embedded and how society can and should begin to take power back through economic mutualism and political federalism.

Unfortunately, in the final chapter of the first part of Du Principe Fédératif, Proudhon stated that there was no need to develop the political economy of his theory of federalism. "Le public”, he argues, “qui depuis quinze ans a plus ou moins suivi mes travaux, sait ce que je veux dire”. ${ }^{16}$ Of course, today it is rare to find anyone who has read any of Proudhon's earlier works, and a synopsis would have been helpful to say the least. This statement is also unfortunate because it gives the impression that we need not look forward to any of his later texts for the political economy of federalism. I therefore contextualise Proudhon's mutualist theory of political economy in relation to his international political theory in the second half of the chapter.

\footnotetext{
${ }^{16}$ Proudhon [1867a], p. 80.
} 


\section{The Political Antinomy}

Proudhon begins his discussion in Du Principe Fédératif with the bold assertion that, when it comes to the study and practice of politics, there is only one rational a priori that matters and that this is the antinomy between authority and liberty. How he comes to this view and why there is only one meaningful political antinomy is not explained very clearly at all. Much like Carl Schmitt's friend/enemy distinction, ${ }^{17}$ also no less questionable in terms of its origins and ontological status, the antinomy between authority and liberty performs an analytical function and helps Proudhon make claims about the nature of politics. For example, we know that for Proudhon, like Kant before him, the antinomies are productive. Proudhon's contribution was to suggest that these antinomies are not only rational but real, moreover they exist 'out there' too. Thus rational conflict between authority and liberty are mirrored in the real world where these struggles are actualised.

Proudhon argues that the antinomy between authority and liberty has given rise to four political regimes, which, he argued, should first be understood as "conceptions idéales”. ${ }^{18}$ Thus, for Proudhon, while monarchy, panarchy, democracy and anarchy are "ideal conceptions", they can also be divided between two distinct "regimes". ${ }^{19}$ The first is the regime of liberty, which includes democracy and anarchy; and the second is that of authority, which includes monarchy and panarchy. Panarchy, or the government of all by all, is a synonym for communism in Proudhon's lexicon. ${ }^{20}$ This four-part distinction largely corresponds to Aristotle's, but Proudhon's contribution is to underpin it with the concept of the antimony. Moreover, Proudhon argues that each of the four 2ideal conceptions" are fated to remain "perpetual desiderata” precisely because in reality actual political systems represent temporary and varied manifestations of the balancing between the two regimes of liberty and authority.

\footnotetext{
${ }^{17}$ Schmitt [1985].

${ }^{18}$ Proudhon [1867a], p. 23.

${ }^{19}$ Ibid., p. 13.

${ }^{20}$ Ibid.
} 
Thus, while the concept of the antinomy and of political regimes helps conceptualise, and the ideal conceptions help us construct taxonomies, the inherent and irresolvable antimony between authority and liberty, both in theory and in practice, means that all actually existing political systems are mixed. This is because, Proudhon argues, “[t]outes ces idées aspirent à se rendre dominantes: leur prétension à l'omniarchie n'est pas douteuse." ${ }^{21}$ The basic impulse for authority and liberty becomes couched in religious language before it gives way to metaphysical theories which contain the remnants of the religious. Science alone can penetrate the mystery of political order, and to do this, it must turn to history. Thus, the concept of the antinomy helps us explain conflict and why these positions break down. There is thus temporal and contextual variation overlaying the underlying permanence of the political antinomy.

Proudhon takes Rousseau as his key counter-example here. What he argues is that Rousseau's theory fails to account for the actual history of states and replaces it with a theory which posits the legitimacy of the state derived from ostensibly a thought experiment, as opposed to the product of actual human agency. ${ }^{22}$ Rousseau's concept of political unity exasperates the antinomic balancing between liberty and authority by subsuming both beneath the imperative of unity and sovereignty. This attempt to resolve the political antinomy is futile to Proudhon who, following Kant here, claims that this is not only impossible in theory, but also in practice. To illustrate his proximity to Kant, but in direct opposition to his and Rousseau's theory, he argues that with the actual growth of states in size, the antinomy between authority and liberty becomes so complex that states inevitably republicanise themselves.

L'absolutisme résiste de son mieux, mais s'en va; il semble que la RÉPUBLIQUE, toujours combattue, honnie, trahie, bannie, s'approche tous les jours. Quel parti allons-nous tirer de ce fait capital pour la constitution du gouvernement? ? $^{23}$

\footnotetext{
${ }^{21}$ Proudhon [1982], p. 127.

${ }^{22}$ Proudhon [1867a], p. 15.

${ }^{23}$ Ibid., p. 43.
} 
In a veiled critique of Kant he continues by arguing that "le simple ne sort pas de l'idéal, n'arrive pas au concret." ${ }^{24}$ In fact it is the other way around - the real undermines the ideal. Given their preconceived assumptions about political order and authority, Rousseau and Kant could only see this slow erosion of authority as potentially disastrous, as opposed to pointing towards the need for less absolutist conceptions of political order. Thus, how ironic, but also how illustrative this is of the political antinomy, Proudhon argues, “où le peuple ne peut exercer la souveraineté sans s'exposer à briser le gouvernement, ni le gouvernement user de sa prérogative sans marcher à l'absolutisme!"25

Chapter five of Du Principe Fédératif sets out in some detail how all political systems are thus inherently entropic, or in a condition of "dissolution sociale”. ${ }^{26}$ For Proudhon, this tendency to collapse is inherent to order and arises from the impossibility of transcendental absolutism, order or rationality. Thus, given this and the inherent complexity of political and economic organisation, what is needed, Proudhon argues, is a fuller understanding of the dynamics of social change and dissolution so that institutions can be built which better balance the competing demands of authority and liberty as they change. Proudhon developed this theoretical approach into a philosophy of history that chimes with the work he did on international relations, and substantiates the normative project to follow.

\section{The Philosophical History of State Formation}

Proudhon argues that the state in embryo is the family and this is a regime of authority par excellence. What he argues over and again here is that authority constantly gives way to liberty, but strangely, should not do so in the family. Proudhon argues that in the original European tribes the father was at once leader, elder, warrior, owner and patriarch. Monarchy is, Proudhon argues, the modern equivalent institutionalised, and with exponentially more power. The king sees himself as the head of his own family which quickly becomes conflated with society as such: "En deux mots .... L'état, c'est

\footnotetext{
${ }^{24}$ Ibid., p. 23.

${ }^{25}$ Ibid., p. 71.

${ }^{26}$ Ibid., p. 30.
} 
lui." ${ }^{27}$ This original regime of authority is characterised by the indivision of powers, but it quickly becomes clear that power cannot actually be monopolised and delegation and the division of powers is the first act of the antinomic regime of liberty.

In the previous chapter I illustrated how Proudhon understood social order as derived from collective reason and collective force. I also demonstrated that Proudhon believed war to be the most important cause of social change and that it was (or is) ruptures in the economic equilibrium that is the most significant cause of war. Here Proudhon supplements this by showing that in the absence of war states will dissolve and change by buckling under the weight of their own internal contradictions. In this work, Proudhon also discusses the actual social cleavages that animate these regimes of authority and liberty and how they too are propelled by economic causes.

As with his previous works, Proudhon begins by arguing that it is the "inequality of fortunes" which is the clearest markers of social cleavage. He argues that there are at least seven economic classes: "Guerriers ou Nobles, Prêtres, Propriétaires, Marchands, Industrieux, Paysans.” Crucially, he adds one other class: "Là où la royauté existe, elle forme caste à elle seule, la première de toutes: c'est la dynastie. ${ }^{, 28}$ While we have to wait for De la Capacité before we get a full explanation of how Proudhon understands class, and I will discuss it in the final part of this chapter, what he argues here is that each of these classes vies amongst each other for social power and seeks to universalise their absolutist conceptions of either authority or liberty. Of course, this conflict usually results in a compromise, and thus mixed forms of government.

Historically, he argues, royalty has acted as the pivot of social conflict in Europe because of its historic control of the use of force in society. Around this pivot, the other groups can be divided between the aristocracy and bourgeoisie, the proletariat and peasants. He expands the analysis like this:

\footnotetext{
${ }^{27}$ Ibid., p. 20.

${ }^{28}$ Proudhon [1967a], p. 31.
} 
Si l'aristocratie s’unit à la royauté, le gouvernement qui en résultera sera une monarchie tempérée, actuellement dite constitutionnelle; - si c’est le peuple qui se coalise avec l'autorité, le gouvernement sera un Empire, ou démocratie autocratique. La théocratie du moyen âge était un pacte entre le sacerdoce et l'empereur; le Califat, une monarchie religieuse et militaire. ${ }^{29}$

While political entropy is as inevitable as social conflict, the precise nature of the future world order is uncertain. Proudhon takes his analysis from the world around him and we can see in this analysis the evolution of French and Italian society, the evolution of the Ottoman Empire and the Papal states. State/society relations thus define modern political community. But there is no reason to argue that the same analysis could not be applied to non-modern political communities with equal analytical results, since what underpins this theory of politics is a general philosophy of order.

Turning to the problems of his own time, Proudhon argues that 'the people' ought to be more enamoured of liberty given their relative position in society, but what he argues is that actually it is the bourgeoisie which have most to gain from it. Thus when the people unite with the state, autocracy and empire emerges; but when the people unite with the bourgeoisie against the state, republicanism emerges. This theory underpinned his critique of Polish nationalism, which, without a historic middle class to ally with the people, he argued, would fail to bring liberty to the country. The people on their own, Proudhon argues here, are by the fact of their social exclusion most vulnerable, but also the least concerned with their lot since they have so little to lose and will quickly align with the strongest force in society if they can promise to protect their lot. This observation was taken from the populism of the Second Empire. Thus, as Proudhon had been arguing since General Idea of the Revolution, published in 1851, it is the bourgeoisie, he argues, that are the true revolutionary force in society. This is due to their desire to be either power-sharers or released from the grip of taxation and restriction. This impulse, when supported by the people, leads to deepened constitutionalism.

${ }^{29}$ Ibid. 
But with each see-saw of the political antinomy, caused by either political entropy or war, it becomes increasingly clear that politics is simply not tenable on the statist or authoritarian model. Proudhon argues that "l'arbitraire entrant fatalement dans la politique, la corruption devient bientôt l'âme du pouvoir, et la société est entraînée, sans repos ni merci, sur la pente sans fin des révolutions.”30 The goal must be to find a system of government that holds authority and liberty in a dynamic balance, to find a system that can redress the inherent corruption in society, a system that can emancipate as opposed to simply restrain, and a system that can redress social inequality and justly balance inherently unequal social relations. If the right principle of order can be found and the correct form of institutional arrangement can be built upon it, then why not assume that society can be ordered equitably and justly? Proudhon is so convinced that he is right about this, that in an uncharacteristic proclamation of scientific hubris he argues:

Ce double mouvement, l'un de rétrogradation, l'autre de progrès, et qui se résout en un phénomène unique, resulte également de la définition des principes, de leur position relative et de leurs rôles: ici encore nulle équivoque n'est possible, pas la moindre place à l'arbitraire. Le fait est d'évidence objective et de certitude mathématique; c'est ce que nous appellerons une LOI. $^{31}$

If this is the case, then which political systems follow? Proudhon argues that the answer is federalism.

\section{The Principle of Federation}

Proudhon is quite aware that the federal principle is a liberal principle "par excellence", underpinned by the equally liberal idea of contract. Proudhon bases his idea of a contract on the civil code and argues that there are four species of contract - domestic, civil, commercial and political - but they are all by their nature synallagmatic or bilateral,

\footnotetext{
${ }^{30}$ Ibid., p. 39.

${ }^{31}$ Ibid., pp. 41-42.
} 
commutative and aleatory. The political contract, the subject of such heated dispute for centuries, is only morally valid, Proudhon argues, if it is synallagmatic or commutative.

Yves Simon makes the important observation that Proudhon's theory of the contract overlays the Aristotelian typology of justice. ${ }^{32}$ Aristotle distinguished between legal, distributive and commutative justice. The former defines the relations of the parts to the whole; the second the relation of the whole to its parts or for ease of expression the relationship of the state to the rest of society; while the third governs reciprocal obligations and presupposes neither centre nor sovereign. This is the basis of Proudhon's theory of justice and we can understand why it appealed without much difficulty.

First, given that for Proudhon society (as opposed to the family) had no natural centre, no transcendental order or form, the distributive and legal conceptions of justice would be spurious or partisan. Proudhon was fond of citing Pascal here stating that "with my system, the centre is everywhere, the circumference nowhere. This is unity."33 Secondly, given Proudhon's conception of the antinomy, it is easy to see how balancing is more easily achieved where people freely associate to realise their own sense of justice, rather than have a form of association imposed upon them according to principles they neither care for nor are likely to understand. Third, commutative contracts are unilateral but reciprocal, so if they no longer perform their function, they are no longer binding. They are thus contingent and malleable, but correspond to and help regulate what is an inherently complex reality. In summary, he states it like this:

Pour que le contrat politique remplisse la condition synalagmatique et commutative que suggère l'idée de démocratie; pour que, se renfermant dans de sages limites, il reste avantageux et commode à tous, il faut que le citoyen, en entrant dans l'association, 1. ait autant à recevoir de l'État qu'il lui sacrifie; 2. qu’il conserve toute sa liberté, sa souveraineté et son initiative, moins ce qui est relatif à l'objet spécial pour lequel le contrat est formé et dont on

${ }^{32}$ Simon [1987], p. 228.

${ }^{33}$ Cited in Vincent [1984], p. 215. 
demande la garantie à l’État. Ansi réglé et compris, le contrat politique est ce que j’appelle une fédération. ${ }^{34}$

What Proudhon allows us to see here is that all treaties, pacts and laws are effectively part of the same species. Variation over time can be seen in the systems of rationality used to explain and justify them. Hierarchy is rationalised first by theology, then by metaphysics and finally by science. Proudhon argues that we need to see these systems as historical constructions, not as transcendent or natural; they are socially constructed principles of justice and cooperation that vary in terms of actors involved and their social positions relative to one another. The divine pact, the social contract, and the actual contract all signify variations on the same theme. Proudhon summarises this argument and moves it on by arguing that the political contract is federation. ${ }^{35}$ By this he means:

FEDERATION, de latin foedus, génitif foederis, c'est-à-dire pacte, contrat, traité, convention, alliance, etc., est une convention par laquelle un ou plusieurs chefs de famille, une ou plusieurs communes, un ou plusieurs groupes de communes ou Etats, s’obligent réciproquement et également les unes les autres pour un ou plusieurs objets particuliers, dont la charge incombe spécialement alors et exclusivement aux délégués de la fédération. ${ }^{36}$

In the footnote he continues:

Dans la théorie de J.-J. Rousseau, qui est celle de Robespierre et des Jacobins, le Contrat social est une fiction de légiste, imaginée pour rendre raison, autrement que par le droit divin, à l'autorité paternelle ou la nécessité sociale, de la formation de l'État et des rapports entre le gouvernement et les individus. Cette théorie, empruntée aux calvinistes, était en 1764 un progrès [... mais] [d]ans le système fédératif, le contrat social est plus qu'une fiction; c’est un pacte positif, effectif, qui a été réellement proposé, discuté, voté, adopté, et qui se modifie réguilièrement à la volonté des contractants. Entre le

\footnotetext{
${ }^{34}$ Proudhon [1867a], p. 46.

${ }^{35}$ Ibid.

${ }^{36}$ Ibid., p. 47.
} 
contrat fédératif et celui de Rousseau et de 93, il y a toute la distance de la réalité à l'hypothèse. ${ }^{37}$

What this shows is how deeply engaged he was, not only in the theoretical debates of his time, but also the political and historical origins of those debates - neither of which is regularly conceded in the literature on Proudhon's thought because of the almost exclusively analytical approach it takes. But what we also see here is that Proudhon's social contract, like the rest of his political philosophy is realist in its ontology and historical in its justification. He is clear also that the political contract can be used by any group that so obliges itself to another, and by showing how precarious these contracts will be, how asymmetrical and contingent they are, Proudhon forces us to stare the contingency of all social life straight in the face.

By contrast, the Jacobins and the nationalists rallied behind ideas of national unity, state centrism and popular sovereignty, assuming that that would bring an automatic harmony to social life or return social life to a Rousseauean pre-social. Proudhon's realist metaphysics and his historical method is thus, I would argue, more reflective of social reality than either Kant or Rousseau (and to a lesser degree Comte) and it is they who ought to be branded the utopians. Proudhon argues that states, domestic and international political groups and cleavages, and wider social forces need to be recalibrated internally to achieve a better balance of liberty and authority, and then their relationships federated by commutative contract. He makes this argument based on the argument that science has shown the spurious nature of the pervious rationalisations of social order. Ironically, given his awareness that the Swiss Calvinists influenced Rousseau, it is the Swiss confederation that nevertheless provides Proudhon with all his empirical evidence as to the prima facie functioning of a federal and confederal model. ${ }^{38}$ The army ought to be in the hands of the communes, he argues, ${ }^{39}$ constitutive states ought to be superior to the

\footnotetext{
${ }^{37}$ Ibid.

${ }^{38} \mathrm{He}$ is vague with his distinction between the two systems because the distinction had not been made concrete at that time. Cf. Nelson [1975], p. 37.

${ }^{39}$ Proudhon [1867a], p. 56.
} 
federal centre, ${ }^{40}$ power must be delegated downwards, and so on and so forth. This was discussed in some detail in chapter one and I will not expand upon it here.

My intention here is not to be glib, but to indicate that Proudhon's social ontology naturally leads to his anarchist conclusions about deliberative and participatory democratic processes, the undermining of authority claims, and a reconstruction of society along federal lines. I have not discussed the political economy of federalism here because it follows in the next part of the chapter. However, I will say a few words about the international aspect to Proudhon's theory as it is vital to the discussion and argument of chapter one.

\section{The International System and the Congress of Vienna}

For Proudhon the international system was not a discrete area of social interaction, nor did it operate according to fundamentally different principles or laws of social action. The best way to illustrate this is to show how he understood what he called "natural groups" in society and the ways they interacted and counterbalanced one another. This is a more detailed discussion of the idea of social cleavages. Then, by turning to different types of group we can see the same sorts of processes occurring at a nominally international level.

In Contradictions Politiques, Proudhon presents a good synopsis of the idea of natural groups. These groups are any collectivities that "willy-nilly impose upon themselves some conditions of solidarity ... which soon constitutes itself into a city or a political organism, affirms itself in its unity, its independence, its life or its own movement (autokinesis), and its autonomy”. ${ }^{41}$ In De La Capacité, which I will discuss in more detail in the final part of this chapter, Proudhon adds to this by arguing that this independence can be seen in the ideational forms used to signify social cohesion - or in other words, how collective reason overlays natural groups consolidated according to their internal relations of force and in relation to other groups. Thus, he argues,

\footnotetext{
${ }^{40}$ Ibid., p. 48.

${ }^{41}$ Cited in Vincent [1984], p. 218.
} 
Ce qui importe surtout à l'historien philosophe, c'est d'observer comment le peuple s'attache à certaines idées plutôt qu'à d'autres, les généralise, les développe à sa manière, en fait des institutions et des coutumes qu'il suit traditionnellement, jusqu'à ce quelles tombent dès mains des législateurs et justicières, qui en font à leur tour des articles de loi et des règles pour les tribunaux. $^{42}$

Thus, groups are the institutional manifestation of collective reason and force that we discussed in the previous chapters, but here these groups are political and social, temporary and contingent, but also relational and overlapping and institutionalised by both ritual and rules. They can be towns, cities, regions, workshops, religious groups, industries and so on, none with fixed boundaries and often overlapping. These groups are also ecologically contingent, reflecting the constraints of the geological and ecological conditions from which they emerge, as discussed in the previous chapter. They are often, though not always, in conflict with one another and with nature, but tend to find a balance with nature over time - with the exception of modern society of course. What is also clear is that the system as a whole is anarchic, with rules and laws emerging in time and also eroding over time. Before we go any further it is worth noting that there is thus a clear link between the analysis of natural groups as objective social facts, the ideas which animate them, and the relational forces within which they are constituted. Proudhon also argues that this analysis suggests alternative normative principles of political order specifically anarchism as opposed to statism.

Statism tends towards unity, the attempt to erase contingency, and the erasure of spontaneous social and ideational cleavages in the interest of a principle of unity set down by the centre or the newly preponderant power in a given territory. This creates a spurious anarchy premised on the attempt to assimilate and impose order domestically, which creates the very same anarchy internationally. Proudhon argued against the domestication of society and suggested that these natural groups ought to federate amongst themselves to ensure that the liberty of all was the pre-condition of the liberty of one. Thus the international system would find its principle of order in the constitutional

\footnotetext{
${ }^{42}$ Proudhon [1982], p. 119.
} 
relations that tie states to reciprocal obligations. Over time, Proudhon argues, this process would reduce the state to the status of initiator or guarantor, as society became stronger and more self-governing. In relation to international politics, Proudhon argues the following:

Le principe de la pluralité des puissances souveraines [...] en autres termes, la loi politico-économique de la division de la collectivité humanitaire en États indépendants, protégés par leur équilibre, est une idée essentiellement fédéraliste, qui a changé le cours de la civilisation, et dont l'influence descendue de si haut, ne peut manquer de transformer à la longue, partout où elle existe, l’unité intérieure ou la centralisation des Etats. La Révolution française devait reprendre cette tradition du traité de Westphalie. ${ }^{43}$

Prior to the Treaty of Westphalia, the religious authority of the Pope and his link to God set down the principle of European order. For Proudhon, Westphalia signified the first shift towards recognising secular conceptions of the balancing of social order even if, but perhaps because, kings retained the ideas of divine right to rule. However, after the French revolution this was no longer feasible in the way it had been in the past. Almost overnight, and following the American example, as Proudhon recognises, Europe constitutionalised itself internally while the treaties that arose from the Congress of Vienna stipulated the parameters of state rule vis-à-vis their neighbours. By way of empirical evidence, he lists nearly 100 constitutions that were ratified, replaced and amended between 1789 and 1864. We might also point to the innumerable treaties signed between states since as evidence of the further constitutionalisation of international political life.

It is precisely because of conflict that he argues the following: "A chaque violation répond une protestation, et toujours le débat se résout en faveur de l'équilibre.” ${ }^{44}$ From his mid-nineteenth century vantage point, it seemed to him that the natural European

\footnotetext{
${ }^{43}$ Proudhon [1867b], p. 253

${ }^{44}$ Ibid., p. 276.
} 
order had emerged in the aftermath of the Congress of Vienna and the European Balance of Power.

Les Etats actuels de l’Europe peuvent être regardés comme le dernier produit du mouvement agglomérateur et unitaire, de même que la constitution géologique actuelle est le produit de la dernière révolution du globe. Le traité de Westphalie, en posant le principe d'équilibre, nous indique le moment où a commencé de s’arrêter l'agglomération; les traités de 1815, en ouvrant l’ère constitutionnelle ont préparé la dissolution. ${ }^{45}$

He believed that rather than consolidate further, states would tend to dissolve from this nadir of authoritarian unity. But he was wrong. He was indeed right that "[l]a république une et indivisible des Jacobins a fait plus que détruire le vieux fédéralisme provincial [de la France], évoqué peut-être mal à propos par la Gironde; elle a rendu la liberté impossible en France et la Révolution illusoire." ${ }^{46}$ This ought to be a message to the revolutionaries, but it was not heeded as such. For Proudhon, this centralisation and unification was a disaster for French society, not only because the liberty of the social and political cleavages were crushed and their leaders guillotined, but because these plural groups constitute the only units through which social change and progress could occur and their erasure was simply immoral or unjust.

Le jacobinisme est avant tout unitaire, c'est-à dire monarchique, avec ou sans roi [...] Le jacobinisme est bourgeois dans l'intérêt de l'ordre [...] Le Jacobinisme enfin est juste-milieu [...] Unitarisme, bourgeoisisme, juste milieu: voilà pourquoi la démocratie a tant déclamé contre le traité de Villafranca. $^{47}$

Again, it is because of the historical allusions he makes throughout the development of his theory that the context of the previous chapters has been so important. We can now better understand the basis upon which Proudhon railed against the unification of Italy

\footnotetext{
${ }^{45}$ Proudhon [1867b], p. 312.

${ }^{46}$ Proudhon [1867a], p. 89.

${ }^{47}$ Proudhon [1867b], p. 208.
} 
and Poland and why he pointed to Switzerland as its alternative. What is most striking however, and here I am linking forward to the discussion to follow in the conclusion to the thesis, is that Proudhon's alternative model for Europe is strikingly similar to the pooled sovereignty of the EU today. As Proudhon argued,

La fédération peut exister entre Etats séparés, disjoints et distants les un des autres: il suffit qu’ils déclarent vouloir unir leurs intérêts et se donner garantie réciproque, selon les principes du Droit économique et de la mutualité. Une fois formée, la fédération ne peut plus se dissoudre. ${ }^{48}$

And with some perceptiveness regarding the nature of European international politics, Proudhon remarked:

Déjà, l’on peut prévoir le jour ou une guerre entre deux États, tombant sous la jurisdiction de l'Europe entière, ne serait plus considérée que comme la pression d'une émeute dans un État particulier. Insurrection, guerre civile ou guerre étrangère, ce serait tout un."49

However, Proudhon argued that “L’Europe serait encore trop grande pour une confédération unique: elle ne pourrait former qu’une confédération de confédérations”. ${ }^{50}$ This would demand the devolution of powers from the Imperialist centres and the move towards confederation. Moreover, he believed that by criticising nationalism as a political ideology, he was providing the basis for a more pluralist political ontology and a more pluralist political system which would be the extension of the constitutionalism of postRevolutionary France and a means of pacifying European social and inter-state relations. Of course, his exclusion of women from this worldview and political project ensured that sexual cleavages would remain just as fractured and inequitable as they had always been, and that eventually social conflict would arise between the sexes.

\footnotetext{
${ }^{48}$ Proudhon [1982], pp. 221-222.

${ }^{49}$ Proudhon [1867b], p. 259.

${ }^{50}$ Proudhon [1867a], p. 62.
} 


\section{Summary}

Proudhon stated his normative federal theory like this:

1. Former des groupes médiocres, respectivement souvrains, et les unir par un pacte de fédération;

2. Organiser en chaque Etat fédéré le gouvernement d’après la loi de séparation des organes; je veux dire: séparer dans le pouvoir tout ce qui peut être séparé, définir tout ce qui peut être défini, distribuer entre organes ou fonctionnaires différents tout ce qui aura été séparé et défini; ne rien laisser dans l'indivision; entourer l'administration publique de toutes les conditions de publicité et de contrôle;

3. Au lieu d'absorber les Etats fédérés ou autorités provinciales et municipales dans une autorité centrale, réduire les attributions de celles-ci à un simple rôle d'initiative générale, de garantie mutuelle et de surveillance, dont les décrets ne reçoivent leur exécution que sur le visa des gouvernements confédérés et par des agents à leurs ordres. ${ }^{51}$

This system is universalisable and is a loose principle of organisation. It is also a clear echo of his work in De la Justice, where he argued that to “emancipate” labour meant,

Que la liberté individuelle soit respectée; Que la balance des services et des valeurs soit faite; Que la prestation des capitaux devienne réciproque; Que l'aliénation des forces collectives cesse; Que le gouvernement établi sur la démocratisation et la mutualité des groupes industriels, foyers des forces collectives, soit réformé d’après la loi de leur pondération; Que l’instruction primaire soit ôtée au clergé; Que l’enseignement professionnel soit organisé; Que le contrôle public soit assuré; Toutes choses sans lesquelles l'affranchisement du travail est impossible, mais qui répugnent aux intérêts du privilège, autant qu’à la pensée chrétienne. ${ }^{52}$

\footnotetext{
${ }^{51}$ Ibid., p. 58.

${ }^{52}$ Proudhon, [1988/1990c], 1096.
} 
There are strong echoes of Rousseau and Kant in the republicanism of the underlying sentiment of these quotes. However, Proudhon's rejection of the statism that characterised modern thought marks him out as a truly original and insightful social critic and political philosopher. Here political, social and economic cleavages are recognised and encouraged; they are encouraged to democratise so as to ensure that the alienation of the individual ends; all collectives, not solely the collective organism of the nation state, ought to be valued; these groups ought to be both economic and political and their democratisation ought to be the catalyst for the absorbing of the administrative functions of the state back into society. Individual autonomy is realised through the democratic processes of the individual's most immediate collectives - and these can and will be plural and overlapping. Autonomy and public oversight, the division of powers and federation, also act as checks to the despotic appropriation of power and the tyranny of the majority. The relative autonomy of regions, cantons, communes, industries and so forth are also vital to enfranchising not only individuals but also to integrating communities into the fabric of their own social relations, rather than feeding them to the centre. Religion must be removed from education and professional education organised so that the advances of science can be integrated into both society and industry. This could only be possible if the benefits of capital are reciprocal. The question remains as to how this change ought to be brought about?

\section{Mutualism - the Socio-Economic Path to the New Federal Order}

Proudhon closes the first part of Du Principe Fédératif with a chapter titled "Sanction Économique: Fédération Agricole-Industrielle”. Unfortunately, four pages into the chapter he states: “Je n’entrerai à ce sujet dans aucun développement. Le public, qui depuis quinze ans a plus ou moins suivi mes travaux, sait ce que je veux dire.”53 Despite this, it is arguable that the best extrapolation of Proudhon's political economy does not come before Du Principe Fédératif, but afterwards in his posthumously published De la Capacité Politique des Classes Ouvrières (1865). Indeed, as Gustave Chaudey argued in

\footnotetext{
${ }^{53}$ Proudhon [1867a], p. 80.
} 
the concluding pages to this latter work, “[c]e qu'on appelle en particulier le pacte de garantie entre Etats n'est pas autre chose qu'une des plus brilliantes applications de l'idée de mutualité, qui, en politique, deviant l'idée de fédération.”54 But, he continued, international politics remained one of the blind spots of working class thinking. An excessive focus on the need for centralisation in domestic politics, or the capture of state power, or on domestic social and economic problems, had blinded the working class to the problems of inter-state politics and its structuring force on social issues. I want to show now how Proudhon's theory of federalism provided an analytical corrective to the domestic determinants of global political structures. But by integrating federalism with his theory of mutualism, I will show that he also provided an expansion in the normative possibilities for a future world order based on the same principles that he believed, with good reason, would pacify domestic politics.

\section{Mutualist Morality}

Many of the themes Proudhon discusses here are developments of arguments that were well-worn by 1865. Nevertheless, there is a significant amount of original analysis in his mutualist theory of morality. In De la Justice, Proudhon defined justice as mutual respect for the inherent dignity of the other. Conceived more broadly, it was also a theory of justice that saw right as emerging from the equilibrium between opposing forces. This conception of justice as immanent equilibrium was mirrored in the equilibriums that permeated nature, our rational cognitive processes and real political and economic rivalries. When these equilibriums are disrupted, either through natural, man-made or unintentional human action, or simply through the development in individual or social learning and capacity, it often causes serious political, economic and psychological repercussions. This can be war, social (or civil) conflict, famine, and so forth. Proudhon was a realist and saw that law and right emerge from this natural process. He also saw this process as just in itself, if not in its outcomes, and in every instance except in relation to feminism.

\footnotetext{
${ }^{54}$ Proudhon [1982], p. 404 Chaudey was at Proudhon’s bedside taking down Proudhon’s words as he died and was responsible for the publication of the work.
} 
In De la Capacité Proudhon's theory of morality is given its firmest civic and republican formulation, and is tied onto a conception of the process and institutionalisation of respect and dignity. Mutualism, he argues, was originally framed in micro terms, that this is its primordial manifestation and the first impulse is to try to universalise this particularity. Take for example the infant's original love and respect for the father then the patriarch, prince, pontiff, king or czar; “de ces figures il dégage peu à peu l'idée d'autorité: il lui faudra trente siècles pour concevoir la société, la grande famille dont il fait partie, comme l'incarnation du Droit". 55

Again, the family is the microcosm of order and morality and it should be clear that while Proudhon argues that this formulation can be abandoned everywhere else, patriarchal relations must not be abandoned in the family. Permanent revolution was the solution elsewhere and an integral part of this revolution was a change in morals. The previous three French revolutions had been bourgeois affairs and the solutions offered by SaintSimon, Comte, Blanc and others suggest as much. However, with the publication of the 'Manifesto of the Sixty' - to which De la Capacité responds directly - a new working class consciousness and sense of justice seemed to be emerging, which was neither industrial nor peasant, necessarily artisan (though in reality it was probably mostly so) nor bourgeois. The ideas of justice expressed by this new social cleavage forms the very heart of Proudhon's thinking here. Previously dispirited by the results of the plebiscite in support of Napoleon III, the Manifesto of the Sixty represented the stirring of an organic rather than an imposed sense of collective self, and a demand for the political capacity to realise this autonomy. Proudhon had been campaigning for this sense of collective self his whole life and now he sought to give it the idea he thought it needed. This idea was mutualism, and characteristically for his time and his approach, he continued by juxtaposing it with the bourgeoisie morality of self interest.

The bourgeoisie sought guarantees and the reduction of risks so as to assure particular forms of economic advantage - this, as I discussed, above is the source of their constitutionalist impulse in state/society relations and the reason why Proudhon saw them as having revolutionary potential. If aligned with the people, the bourgeoisie would be

\footnotetext{
${ }^{55}$ Ibid., p. 128.
} 
forced to temper their self-interest and seek guarantees, support and order. Thus, the ethic of self interest that the bourgeoisie claim unavoidable and providential is nothing of the sort. "Proposez au bourgeois” Proudhon taunts, “de s’engager dans une opération selon des règles du mutualisme, il vous répondra: Non, j’aime mieux rester libre."56 But free from what? Restrictions by states or the working class maybe, but they will gladly engage in mutual relations with other capitalists which circumscribe their freedom if they are to keep to their word in economic exchanges.

On the left, things were little simpler. The communist equivalent, he argued, was "souveraineté collective et de la subalternisation individuelle", 57 typified by the Luxembourg school of thought (discussed in chapter two), which sought to control all economic process through the state thereby, they claimed, negating self-interest in the name of collective interest. In the ideas of "Cabet, Owen ... Plato", Proudhon shows, it is from the state or commune that the individual is granted civic dignity and rights, and nowhere else. This is also despotism and ultimately results in the destruction of society, transforming all social relations into political ones. Divine right is substituted for Rousseau's “collectivité nationale."58 While individualism is deontological in its absolutism, collectivism is consequentialist in its logic of morality. The polarisation of the following two hundred years of European politics originates in this debate.

Proudhon's mutualism, on the other hand, is not a third way. Proudhon begins by stating that rights are derived from the social context in which they are contested and spring directly from the conscience of the individual, conflict that emerges from individual absolutes and social resistance. Bourgeois individualists must at least recognise the social context of their actions to give them any meaning, while collectivists must recognise individuals to explain where the collective comes from in the first place. What Proudhon argued was that rights and morality actually emerge from, and are mutually constitutive of, our duties towards one another. They are not reducible to, nor are they the dogmatic preserve of religion, the state or philosophy, even though these are historical manifestations of social morality. Mutualism presupposes "l'unité sociale du genre

\footnotetext{
${ }^{56}$ Ibid., p. 226.

${ }^{57}$ Ibid., p. 112.

${ }^{58}$ Ibid., p. 113.
} 
humain”, ${ }^{59}$ but recognises social variability. Indeed, as the previous chapter illustrated, it is this difference that creates the very conflict that presses change forward. It is because of the inescapability of society that humans engage in acts of social altruism and build hospitals, schools, orphanages and crèches; ${ }^{60}$ it is because of the negative effects of unrestricted capitalism that society, particularly the workers whose labour is exploited, fight against it. ${ }^{61}$

\section{Mutualist Capacity}

Inter-personal and collective relationships are bound by rights and duties that are immanent to them. For Proudhon, association, as I discussed in the previous chapters, creates an entity that is irreducible to the individuals which comprise it. It is neither an aggregate of individual wills, nor, however, can it be separated from the individuals that create it. In De la Capacité Proudhon gives us the best discussion of how this collective capacity is constituted.

Proudhon argues that there are two types of capacity - "legal” and "real”. Legal capacity is treated by Proudhon as relatively self-evident. It refers to all those human and collective activities that are recognised and either sanctified or prohibited by law and underpinned by force. Law "confers"62 capacity upon individuals and groups by supporting their occurrence or prohibiting them by force. "Real" capacity, on the other hand, is pre-legal or socially emergent derived from the forces that underpin law.

Proudhon argued that for a group or individual to have real capacity it must have three further properties. First, he or it (not she for obvious but completely biased reasons), must have consciousness of itself, its dignity, value and place in society. In other words, it or he must have an idea of its role in society, an idea of how society affects its functions and interests. Secondly, the group or individual must affirm this idea as a manifestation of his or its understanding of social life. Finally, it is no good to simply think it through and

\footnotetext{
${ }^{59}$ Ibid., p. 127.

${ }^{60}$ Ibid., p. 132.

${ }^{61}$ Cf. Kropotkin [1989], Polanyi [2001]

${ }^{62}$ Proudhon [1982], p. 88.
} 
proclaim it - the idea of collective or individual capacity must be affirmed practically. ${ }^{63}$ This formulation gives sociological content and weight to the concept of natural groups developed in the previous section. Furthermore, it is not restricted to two-class analysis of state or capital vs. society or worker, but encompasses all the "natural groups" of society and is thus inherently more sociologically complex. Political institutions and practice, he comes to argue, ought to be a reflection of this social complexity rather than seek to obliterate it through doctrines of unity and nation, state prerogative or ego-centric individualism.

However, there is clearly variation in "degrees of capacity", and this is directly related to the difference between having consciousness of ones interests and the success of the practical demonstration and affirmation of these capacities. ${ }^{64}$ In other words, groups can have capacity, but be wrong about how they ought to act because of a misunderstanding of the nature of the social context. Also, an idea of class consciousness can exist without fully understanding how the interests of that class ought to be achieved (the question of means), and without a firm understanding of the appropriate aims of the campaign for capacity (the ends). This, Proudhon argued, was the post-1848 situation of the French working class and the problem to which his work was directed.

\section{Economic Mutualism}

Proudhon was right to show that the Second Empire bourgeois order was based upon the principle of authority, and as many commentators have noted, liberty and the means to realise it were not de rigeur for Louis Napoleon, Mazzini, Garibaldi, Cavour or anyone else during that period. Each used Rousseau's theory of the "collectivité nationale”,65 for his own ends. Transposed onto the economic realm capitalists employed this principle of authority in their factories, on the land and in their relations with government, taking their own economic sovereignty as the expression of the interests of the people they paid to work for them. Workers must alienate their labour in order to realise their freedom much in the same way as they must alienate their liberty in order to realise political freedom.

\footnotetext{
${ }^{63}$ Ibid., pp. 88-89.

${ }^{64}$ Ibid., p. 91.

${ }^{65}$ Ibid., p. 113.
} 
Proudhon turns this argument on the ideas of Saint-Simon and the industrial bourgeoisie of the early nineteenth century for creating the institution of "industrial feudalism”, a concept he repeats a number of times in Du Principe Fédératif, where analogously "la propriété restait toujours une concession de l'Etat, seul proprétaire naturel du sol, comme représentant de la communauté nationale.”66

Again, taking the distinction between bourgeois society and communism as his main foil, he argues that communism is nothing but an inversion of bourgeois society. Communism, he argues, is the exploitation of the rich by the poor, using the state, now under the control of the communists, to turn the tables on the exploiters. The regime of authority remains and liberty is repressed in the name of the collective.

C’est ainsi que, dans les conceptions du Luxembourg [shorthand, for Proudhon, for the Jacobin socialism of Louis Blanc], le domaine public devait amener la fin de toute propriété; l'association entraîner la fin de toutes les associations séparées ou leur résorption en une seule; la concurrence tournés contre elle-même, aboutir à la suppression de la concurrence; la liberté collective, enfin, englober toute les libertés corporatives, locales et particulières. ${ }^{67}$

Given his analysis of Louis Blanc and the Luxembourg Commission, Proudhon saw, quite rightly as it turns out, that communism in power would mean nothing but,

L’indivision du pouvoir; Centralisation absorbante; Destruction systématique de toute pensée individuelle, corporative et locale, réputée scissionnaire; Police inquisitoriale; Abolition ou du moins restriction de la famille, à plus forte raison de l’hérédité; Le suffrage universel organisé de manière à servir de sanction perpétuelle à cette tyrannie anonyme, par la prépondérance des sujets médiocres ou même nuls, toujours en majorité, sur les citoyens capables

\footnotetext{
${ }^{66}$ Ibid.

${ }^{67}$ Ibid., p. 115.
} 
et les caractères indépendants, déclarés suspects et naturellement en petit nombre. ${ }^{68}$

All this definition lacks is the Napoleonic leader, someone like Stalin perhaps, to complete this short synopsis of Soviet communism. Proudhon, saw 'pure' communism as the tyranny of the anonymous majority. As he put it,

Qu’y auraient gagné la liberté, la félicité publique, la civilisation? Rien. Nous eussions changé de chaînes, et, ce qu'il y a de plus triste et qui montre la stérilité des législateurs, entrepreneurs et réformateurs, l’idée sociale n’aurait pas fait un pas, nous serions toujours sous le même arbitraire, pour ne pas dire sous le même fatalisme économique. ${ }^{69}$

The backhanded swipe at the opening lines of the Social Contract ("man is born free but everywhere he is in chains”) ought not to be overlooked here. Thus, purposive economic associations had to be defined according to function, they needed an idea of their real capacity, they had to assert that capacity within a full understanding of their context and they had to understand this mutualistically if they were to balance their demands against the limits of social possibility and the forces that conspired against them.

Mutual assurance institutions are examples of economic mutualism and mutualist association. Proudhon also developed the idea for a bank of the people, sought to encourage trade guilds, unions, credit exchanges, anything which imposed reciprocal obligations upon the contracting parties and which sees full and democratic participation in the governance of collective interdependence as a prerequisite of economic capacity. ${ }^{70}$ Proudhon is clear that the liberal school of economics is absolutely right to argue that liberty is the core of any economic force because without it no action could be taken. But in the name of justice, by virtue of its mutuality, liberty must and can only be tempered by itself. Again, the liberty of all is the precondition of the liberty of any because it is only through their free and mutualist balancing that social relations can cohere equitably

\footnotetext{
68 Ibid.

${ }^{69}$ Ibid., p. 188.

${ }^{70}$ Ibid., p. 133.
} 
at all. Liberty is the precondition of justice, just as it is the precondition of conflict and both need to be institutionalised rather than suppressed, and via the economic realm, not the political.

\section{Political Mutualism}

However, this economic recalibration of society does have a political corollary. Under a mutualist system collective forces, be they economic, intellectual or political, are balanced and held in reciprocal contractual relations. These relations are given the force of law and derive their legitimacy from the asymmetric needs they satisfy. ${ }^{71}$ Should a mutualist society descend into intolerance this would counter the very basis of the mutuality of the society and would render the society null and void and its statutes suspended. Where society collapses, justice cannot be said to regulate people's actions. The new constellation would represent a new form of justice, but not necessarily a better one.

But this conflict is not a singular event - it is woven into the fabric of society. Proudhon pointed to the differences in the political behaviour of towns and country as obvious social cleavages with different interests. He turned to the underlying variation in the purpose and use to which property is put, to explain differing attitudes. Workers fight for rights in towns since they have no property, while the peasants fight for their little bit of land in the countryside because elaborate political rights are relatively meaningless when you are, and would like to remain, a farmer. Therefore, as Proudhon shows, rural populations saw Napoleon III as their saviour since he inherited the tradition of smashing the institution of the nobility and gave the people their land and thus their independence (a common tactic for any leader wishing to gain or retain power). Because the rural population (including the middle classes) had been made richer by the extension of the railways Napoleon III became their ally.

This does not make their defence of Louis Napoleon right, however. Proudhon argued that they could not see that their minimal gains were simply that. The rural poor could not

\footnotetext{
${ }^{71}$ Ibid., p. 186.
} 
link the plight of the workers against the industrial feudalism of the cities, which implied a critique of the coup, with their own battle against the feudalism of land in the countryside. $^{72}$ The mutually undifferentiated conception of the needs of the working people (with labourers distrusting peasants and vice versa) was the root cause of the intractable cleavage. Nevertheless, Proudhon believed it was all still the same fight against exploitation, and his defence of the peasant's autonomy, ought to be seen in this light. ${ }^{73}$ His mutualist system and the analytical demands and responsibility it places on the agitator to respect the dignity of the other is a vital contribution to processes of social change.

It is thus that, by contrast, Proudhon argues that the mutualist contract is "le contract social par excellence", it excludes "tout égoïsme, tout parasitisme, tout arbitraire, tout agiotage, toute dissolution”. ${ }^{74}$ "La mutualité, ou la société mutuelliste est la Justice.”75 This is because if authority is not absolute and society cooperates equity will emerge. As the natural groups become more aware of their interests and as their past blinkers slip away then social order will be re-calibrated. At each step, however, decision-making must be direct and democratic.

Si le droit politique est inhérent à l'homme et au citoyen, conséquemment si le suffrage doit être direct, le même droit est inhérent aussi, à plus forte raison, à chaque groupe naturellement formé de citoyens, à chaque corporation, à chaque commune ou cité; et le suffrage dans chacun de ces groupes, doit être également direct. ${ }^{76}$

This formulation implies the need to affirm the legal capacity of infinite social groups, to repel the encroachments of the centre; build strong economic democracy to balance the encroachments of private interest, and strong municipal government to balance the power of the rural population. These, as he argued above, need to be constitutionally guaranteed,

\footnotetext{
${ }^{72}$ Ibid., pp. 68-70.

${ }^{73}$ Ibid., pp. 67-68.

${ }^{74}$ Ibid., p. 193.

${ }^{75}$ Ibid., p. 195.

${ }^{76}$ Ibid., p. 268 (emphasis added).
} 
which is simply another way of saying contractual. In a formulation that was to inspire the Paris Commune, but was taken directly from the Swiss experience, he argues that:

La commune est par essence, comme l'homme, comme la famille, comme toute individualité et toute collectivité intelligente, morale et libre, un être souvrain. En cette qualité la commune a le droit de se gouverner elle-même, de s’administrer, de s’imposer des taxes, de disposer de ses propriétés et de ses revenus, de créer pour sa jeunesse des écoles, d’y installer des professeurs, de faire sa police, d'avoir sa gendarmerie et sa garde civique; de nommer ses juges $[\ldots]$ etc. ${ }^{77}$

The question of ought is all well and good. But perhaps a more important question to ask now is: 'how?'

\section{Mutualist Tactics}

The first thing to say is that Proudhon's tactical approach was moral and intellectual and much of what one should or should not do in order to bring about a more mutualist society is covered in all his works. He aims his admonitions at the diplomatic community, to state leaders, to the bourgeoisie, to mothers, to children, to the workers and to the peasants. In the period immediately prior to the penning of De la Justice, Haubtman notes that Proudhon calls himself a "moraliste consultant" ${ }^{78}$ His advice was always context specific and it would be impossible to cover it all here. But there is a simple principle that runs through it all. He sums it up like this in Du Principe Fédératif: "Et comme je ne fais pas de mes idées un instrument de parti ni un moyen d'ambition personnelle, toutes mes espérances d'actualité et d'avenir sont exprimées par [...] Fédération progressive”. ${ }^{79}$ In De La Capacité, this progressive federation is given a far more detailed exposition and is called mutualism and the argument presented here remains the linchpin of the division between the statist and anti-statist left and the question of revolutionary tactics.

\footnotetext{
${ }^{77}$ Ibid., p. 285.

${ }^{78}$ Haubtmann [1988b], p. 30.

${ }^{79}$ Proudhon [1867a], p. 84.
} 
Proudhon's tactics are both ideological and organizational, but he is clear that organisational principles are reducible to ideas about how we ought to organise, and thus, in the final analysis, it is perhaps fair to argue that conceptions of the nature of society and how it evolves and settles, are the precondition of any tactical approach to changing it in the future. As Proudhon states it: "Toute société se forme, se réforme ou se transforme à l'aide d'une idée.”80 He hoped that mutualism, federalism or anarchism, would be one such idea, which both explained the history of the present and provided equitable means of moving forward.

Nevertheless, there were specific things Proudhon called for. For example, throughout his works, he appeals to the good sense of the bourgeoisie to collaborate with the workers to bring the state to heel, ${ }^{81}$ but he was realistic enough to admit that they probably will not deliver for as long as the state protects, and has an interest in protecting their interests. Thus, despite the promises of the French revolution, the new bourgeois order is "la féodalité nouvelle» ${ }^{\nexists 2}$ where seigniorial rights have simply passed to the new bourgeoisie and the people are held in wage slavery. Individuals and groups should campaign for political devolution and progressive federation of natural groups and build strong localised government as a bulwark against the centre. ${ }^{83}$ There ought to be further decentralisation of industrial functions, ${ }^{84}$ and a de-linking from capitalism and the state by cooperatively/mutualistically organising immediate communities and workplaces.

All these groups ought to be governed through direct democracy, ${ }^{85}$ with recallable delegates sent up to the appropriate decision making levels. ${ }^{86}$ Proudhon argued for worker credit institutions, mutualist banking, and other such contemporary commonplaces, so that workers could achieve autonomy through mutual aid, as opposed to relying on state benefactors such as that proposed by the Luxembourg commission. There is also the assumption that the overarching market relations would change due to

\footnotetext{
${ }^{80}$ Ibid., p. 127.

${ }^{81}$ See the preface to Proudhon [1989].

${ }^{82}$ Proudhon [1982], p. 100.

${ }^{83}$ Ibid., pp. 278-279.

${ }^{84}$ Ibid., p. 404.

${ }^{85}$ Ibid., p. 268.

${ }^{86}$ Ibid., p. 217.
} 
the difference in the relations constituted by mutualistically organising the constitutive units. Businesses and industries ought also to be federated and unionised, so that coordination can take place that is open to discussion in the interests of society, as a whole as opposed to specific elites within them.

He argued that this process of constitutionalising society and democratising the polity and the economy would entrench the international balance of power. International confederations of states and labour unions, towns, cities and regions can be plural and overlapping. ${ }^{87}$ Extra societal Phalanstaries are not the solution for Proudhon, ${ }^{88}$ since the world is self-contained and we need to work out how to work together, not in isolation. The working class must assert its interests by a plurality of means and organise collectively and democratically to achieve them. There is no blueprint, but the state must be avoided as an instrument of social change precisely because it is so adept at co-opting disparate interests to its own. Proudhon argues that the workers united would be a serious force for the managers to reckon with and that conciliation and mutual respect ought to underpin interrelations and bargaining. Proudhon was against strikes for a number of reasons, not least because the working class were most unable to endure the strike economically while the capitalists could, but also because strikes might break an industry, and the resulting financial hardship would be no good to anyone. Industry bosses can also use the state to break strikes and rebellion promotes more repression, and so on. ${ }^{89}$ The solution was not more state control of industry, but less. As Chaudey argued in the conclusion to De la Capacité, "dirigisme" was not the answer for Proudhon in the $1860 \mathrm{~s}^{90}$ and in this he was charting new territory in social theory. The aim was to push for worker control and self-government.

\section{Domestic Mutualism?}

Sexual relations drop out of his analysis in De la Capcité. This is perhaps explicable by the fact that, prior to and during the writing of De la Capacité, Proudhon was also

\footnotetext{
${ }^{87}$ Ibid., p. 221

${ }^{88}$ Ibid., p. 193.

${ }^{89}$ Ibid., p. 398

${ }^{90}$ Ibid., p. 403.
} 
working on a work called La Pornocratie, ou les femmes dans les temps modernes. ${ }^{91}$ Although this diatribe against feminists and women generally, which is misogynistic in places, was not published in his lifetime, but it nevertheless sealed Proudhon's antifeminist credentials. Little value is added by rehearsing his views here since we have covered the vast majority of his thinking on this matter already.

\section{Conclusion}

How should we evaluate the efficacy of Proudhon's theory of federalism and mutualism? In regard to federalism it is probably worth beginning with Rufus Davis. He argued in a well received survey of federalist theory (that had no mention of Proudhon) that the future of the federal idea "rests with those who can resist the urge to tidy the matter."92 His argument is that comparative, analytical and $20^{\text {th }}$ century deductive or hypothesis driven approaches to federalism fail to provide universal answers precisely because federalism is an evolving, culturally and historically specific form of political organisation whose essence cannot be captured in this way. The designation "federal", Davis argues, tells us nothing more than that a group of political communities "desire to draw together, or reconstitute themselves in a particular form of association, constitutionally and structurally distinct from all other forms of association."93 The uniqueness of the federal pact or contract is derived from the uniqueness of the situation it is designed to facilitate, constitutionalise or legitimate.

Indeed, this is how Proudhon saw the matter too. Federalism by his analysis is no more than a principle and anything more is an automatic restriction on the sheer plurality of forms the principle of contract, pact or feodus might legitimately serve. Arguments about whether Proudhon's system is a confederal or federal system, despite concessions that he did not have the semantic distinction at his disposal, are a case in point. It is also a rather banal objection given that his overall project was less to determine $a$ la Rousseau the best or most precisely defined system for any given state, but to outline the basic principles

\footnotetext{
${ }^{91}$ Proudhon [1939].

92 Davis [1978], p. 216

${ }^{93}$ Ibid., p. 208.
} 
which could and ought to underlie any ordered and just political community - federal or not. These were mutualism in the economic sphere and a federal and constitutional political order to overlay and protect it. The federal pact, given its dependence on the mutualist order would be stable and legitimate since it reflects and is actually, as opposed to presumed to be, the emergent will of the people.

Perhaps it ought to be judged less in terms of its internal coherence and more in terms of whether it could have been realised at his time and whether it would have made a difference. I think the evidence suggests that Proudhon's support for the Treaty of Villafranca and the federalism it promised shows remarkable foresight and realism. We can see on what grounds he argued against the spurious unification of Italy and we can see why the partition of Poland as a temporary solution to the Eastern European balance of power was his favoured solution to the Polish Question. In both cases it was a deeper appreciation for the sociological, cultural and historical cleavages in both countries that gave him the empirical basis in support of his theoretical and normative project. Moreover, his critique of statism and communism were also remarkably perceptive.

But is the mutualist federation "manifestly ineffective" in the face of foreign power as Ritter argues? Mutualist society controls the state and mutualist states ought to extend their internal federation to international federation - this is Proudhon's message. The state had to be made the servant of society rather than a militarising institution which needed bourgeois collusion to finance it. But this was not a call for working class control of the state. This was a call for working class control of their immediate economic and communal priorities and the federation of industries, towns and so on, to absorb the functions of the state back into society. This involved a turn to history, to illustrate the state's historical legacy as a social parasite, and then using the new scientific principles of political economy to help understand what to do about it. This was still no guarantee of success, but it provided radically original principles of social re-organisation at the time. Secondly, Proudhon argued that his federalist polity would be more than capable of defending itself from outside interference. Proudhon argued that the federal system is “[t]rès capable de se défendre si elle est attaquée, les Suisses l’ont plus d’une fois fait 
voir, une confédération demeure sans force pour la conquête.”94 And he argues that, “[l]e vingtième siècle ouvrira l'ère des fédérations, ou l'humanité recommencera un purgatoire de mille ans." 95 The question is not, therefore, whether the mutualist society can protect itself, but whether we can and should change the geo-political and social structures of power in such a way as to make it unprofitable for states to attack one another in the first place.

The problem, as I have discussed in detail in chapter one, was the progressive assimilation of society by the state at this time. By co-opting the discourses of national liberation for state ends, Cavour, Napoleon III, Bismark and others all identified the interests of the people with the interests of the state. This created the very anarchy the state was supposed to have resolved - only this time the anarchy was potentially far more dangerous. Proudhon's alternative would have done the opposite. By democratising state functions (juridical, economic, administrative, military, etc), and thus returning their control to society, and also through developing the "ideas" of mutualism and federalism, Proudhon believed society would be able to rein states in. The emaciated state that remained would become the instrument of society. European federalism would then hold states in bonds of mutual reciprocity, which together might have brought peace. As it turned out, the European state consolidated its role as "racketeer", ${ }^{6}$ then led society through two world wars, facilitated genocide on innumerable occasions, necessitated arms races that brought the planet to the bring of annihilation, and has structured the global economy in such a way as to make the planet ecologically near-inhabitable. It is also states that remain the most significant block to any radical environmental, economic, political and social change.

\footnotetext{
${ }^{94}$ Proudhon [1867a], p. 61.

${ }^{95}$ Ibid., pp. 78-79.

96 Tilly [1985].
} 


\section{Conclusion}

Reform Forever, Utopias Never. ${ }^{1}$

7 This thesis set out to answer two questions: first, what did Proudhon say about nineteenth century international politics and why did he say it? And secondly, how can Proudhon's thought contribute to contemporary IR theory? Answering the first question was in no way straightforward, and the difficulty compounded finding an answer to the second. Proudhon's ideas on world politics have not been presented fully and where they have been partially presented, analysis has been near-universally negative and/or misleading.

The first aim of the thesis was thus to provide a better reading of Proudhon's international political theory. I have argued that substantiating 'better' in this regard implied more contextual sensitivity. Following Quentin Skinner's contextualist methodology, I placed Proudhon's thought within its geo-political, social and intellectual context. Given that my aim has been to uncover Proudhon's intentions and meaning, this context was substantiated by an analysis of the place of Proudhon's thinking about world politics in his oeuvre as a whole. The resulting exegesis, based on a close textual analysis of Proudhon's writings on world politics is both revisionist and, because of the depth and range of Proudhon's approach, necessarily interdisciplinary. What I have found is that Proudhon had a sophisticated sociological and historical approach to world politics, and responded directly to the key political and philosophical debates of the mid ninetreenth century. His analysis led him to campaign against those processes which we now know culminated in two world wars - statism, nationalism, capitalism, the overturning of the 1815 order, and Jacobnism.

This brings me to the second question. In the introduction, I argued that approaching Proudhon's ideas from the perspective of contemporary IR and its intellectual problems would probably provide another misleading caricature of his thought. The reason for this is that our problems were not Proudhon's and past attempts to understand Proudhon from

\footnotetext{
${ }^{1}$ Proudhon [1861], p. i, 5.
} 
within Realism failed. I illustrated this by reference to the work of E. H. Carr and Hans Morgenthau. I suggested, in contrast to these virews, that Proudhon's observations and the theoretical tools he develops to understand his times might be able to help us better understand the evolution of the nineteenth and twentieth century. Thus, I have used the narrative of the thesis to tell a story about how the mid-nineteenth century European balance of power emerged in the way that it did and what the implications were for our own times.

The answer to the second main research question - can Proudhon contribute to contemporary IR - is therefore: not directly. However, this does not imply that this thesis will not make a contribution to contemporary IR or IR theory. I believe the thesis makes two very important contributions. The first has been achieved. Given the near universal ignorance surrounding Proudhon's approach to world politics, the exegesis of his ideas is the first contribution. This contributes directly to the new historiographical work being undertaken discussed in the introduction. I return to this literature again below. Secondly, by telling the story of the tragic evolution of European politics in the nineteenth century, the thesis demands that we ask another question: if Proudhon had such foresight, and if he gave such extensive answers to the problems of his time, why is it that he is ignored in contemporary IR? Perhaps more puzzling, why is it that contemporary critical theory in IR seems to be arriving at many of his criticisms and conclusions without any prior knowledge of them?

In the following section, I provide a chapter-by-chapter overview of my argument and present a summary of Proudhon's approach to international relations. This is necessarily brief, but should provide ample preface for the substantive concluding comments I want to make. In the second part, I provide an account of Proudhon's marginalisation in IR. The key feature of modern IR that explains its ignorance of anarchism has been the economic and ideational proximity of key theorists to the state. The effect this has had on notions of reality and change, the possible and the impossible, has been substantial. Indeed, it is only with the pluralisation of the academy since the 1970s that critical voices have come to the fore. That Proudhon's thought remains unacknowledged here suggests two further things. First, it is clear that Marxism, and later Critical Theory and 
postmodernism, provided the guiding paradigm for the Anglo-American left that was to dominate later critical IR theory. Secondly, unless IR frees itself from the enduring grip of ontological and normative statism, anarchism will never have a place in the discipline. To fail to do so, and to continue to ignore anarchism would, of course, contravene the basic principles of pluralism and science that are supposed to govern the modern academy.

\section{Summary}

Chapter one opened the thesis by showing that nineteenth century nationalism, imperialism and the relationship of the left to a newly industrialised and militarised state, were the key aspects of political life that preoccupied Proudhon from 1858 to his death. He believed that if tendencies continued in their then current fashion, only negative consequences could follow. Central to this was his belief that any unsettling of the post1815 European balance of power would be pitch Europe into certain conflict, particularly when this was driven, not by a desire for co-existence, but by nationalistically justified internal and external imperialism justified by a unitarian politics. This, he argued, would plunge Europe into certain conflict because it exacerbated the international anarchy rather than lessened it. Proudhon advocated a pragmatic approach to European federalism, arguing the left should have supported the treaty of Villafranca and federalism more broadly, and that Switzerland offered the best alternative model to the drive for national unity, which, he argued in relation to Poland and Italy, was a contradiction in terms.

As it transpired Proudhon was both right and wrong. Proudhon did not anticipate that a united Germany would present the greatest challenge to Europe, but he was quite clear that French quasi-Napoleonic imperial ambitions, a united monarchical Italy and the clamour for national unity across Europe were not progressive developments. Moreover, the industrialisation of the military and the co-opting of nationalist movements by the state gave European states both the material means, the personnel and the ideological justification for the imperial wars which followed. What needs to be recalled here is that the rise of Prussia was modelled on the Napoleonic experience, but because of 
widespread European conceptions that Prussia was harmless - even progressive - no one took much notice.

Proudhon was practically alone in his approach to the problems of his times and the solutions he proposed. On the whole, the French left supported French imperial ambitions and some campaigned for war with England (which, presumably, France would win) as the only solution to Europe's problems. Marx had different ambitions to these, but framed the issue in much the same way. On the eve of the Franco-Prussian war, five years after Proudhon's death, he argued:

The French need a thrashing. If the Prussians win, then centralisation of State power will help the centralization the German working-class. German preponderance, moreover, will shift the centre of gravity of the working-class movement of Western Europe from France to Germany [... which would mean the] preponderance of our theory over those of Proudhon, etc. ${ }^{2}$

Marx was largely right. That is what happened. The prussian state modelled itself on the Napoleonic myth and the German revolutionary tradition followed the Jacobins - and much to our cost from a Proudhonist point of view. Chapter two sought to understand where these approaches to the international system and the justifications of them had come from. I demonstrated that both Prussian high politics and Prussian revolutionary ideologies had French lineage. It was generally assumed by the French that what was good for France was good for Europe; if France's internal problems could be resolved and then the solutions exported, all would be well. Marx and Bismark simply replicated this but with a Prussian and communist focus. The providentialist ideas needed to support these political projects were widely available.

Among the broader public, this political philosophy was fuelled by a messianic approach to the military, to the benefits of statism, science and so on. Moreover, with intellectual, industrial and social processes all legitimating the praxis of statism, Napoleon III also had both the intellectual justification and the material means, to champion nationalism in

\footnotetext{
${ }^{2}$ Marx cited in Jackson [1957], p. 140.
} 
Europe. He then set about re-drawing and unsettling the nineteenth-century balance of power in the interests of his own legacy and his industrialist supporters. I argued that French military and ideological developments, particularly in relation to their consolidation by the state, were being co-opted unchallenged by Louis Napoleon, much as they would be by Bismarck in Prussia and by Cavour in Italy. Thus there were two processes at work at this period: statism and nationalism. In this sense, nationalism was not the only blind-spot of the European left, as so many have argued: so was the rise of the modern state. Anarchism stands alone in its realistic assessment of this trajectory.

Chapter three analysed three of the most important intellectual reflections upon, and justifications of, the processes Proudhon stood against, in order to provide another layer of context. I began with Rousseau, as did most revolutionary praxis. I argued in chapters one and two, and developed in detail in chapter three, that he was the intellectual mainstay of the century. His ideas animated the revolutionaries and justified a new social order based on limited male suffrage, the homogenisation of the social order and the alienation of political power. His ideas produced the doctrines of national unity which were to exacerbate the European international anarchy. His ideas filtered through Robespierre, Saint-Simon and Comte into the intellectual waters of the French and European left. His under-theorised or unresolved problem was the international system. Rousseau realised, but could not resolve, the problem the unitary sovereign state created at the international level.

Some thirty years later, Kant tried to solve this problem. He began by rejecting Rousseau's foundations, but he accepted his general political arguments. His advance was to show that the international system would come to be a reflection of the domestic republican order, as opposed to the state of nature it currently was, since it would be the teleological and providential outcome of the egoistic machinations of politicians and the passionate. Napoleonic war in particular was thus providential, because it exported the republican system, and once this system was universalised in a federalist perpetual peace, history would end - thankfully in Kant's view. Again, imperialism was justified to recreate France abroad, and while internal revolution was wrong, for Kant that is, interference in domestic problems by external forces was right-making if the ethic that 
animated it was republican. This doctrine was widespread, and was mirrored not only in Napoleon III's later politics, but also in the colonial ambitions of most European states.

Writing in the aftermath of this first Imperial period, an era wherein the Congress of Vienna seemed to have stabilised inter-state relations, Comte believed that the time had come to order European states rationally, once and for all. Positivism led Comte to believe that the scientists, or Men of Genius, industrialists and the new bourgeoisie, the new vanguard of history, ought to be given the role of establishing the dictates of the positivist Religion of Humanity. Comte's work, building on and influencing the formulation of the epochal doctrines of Saint-Simon, came to legitimise the technocratic and industrialised bourgeois order in France - and ultimately its extension to the rest of the world. In fact, crucially for Comte, Kant and Rousseau, indeed, most nineteenthcentury intellectuals, the current order was rationally pre-ordained, and the proof of this was discoverable through positivistic science.

Despite their politics, Rousseau, Kant and Comte also made profound contributions to understanding human life. These contributions, in so far as they influenced Proudhon, were as follows. Rousseau's romanticism had a huge impact on Proudhon despite his rejection of the Saint-Simonian variety of it. Taking our passions and our feelings seriously was vital to Proudhon's ability to establish a humanist theory of morality. This was also true for Comte. Proudhon's use of Comte's analysis of forces allowed him to show how social and psychological change impacted upon our rationalisations of right and wrong over time. His three-stage philosophy of history also had a huge impact on the way Proudhon explained historical change. Kant provided Proudhon, and most that followed him, with a vocabulary of rights and a way of framing obligation and social duty. He also provided Proudhon with the foil for most of his criticisms of liberal conceptions of right and law. Leaning on Rousseau and Comte, Proudhon came to reject Kant's idealist philosophical foundations. For political reasons, he also rejected the determinism of his philosophy of history and the universalism of his philosophy of right.

The thesis then moved from context to exegesis. Chapters four and five set out Proudhon's critique of Kant and Comte in more detail. Chapter six set out his normative 
solutions to the problem of statism and militarism in the nineteenth century. Here Rousseau and the Jacobins were foregrounded. Chapters four, and five provided criticisms of the claims made on behalf of the state, while chapter six illustrated how best to restrain its activities. In chapter four I illustrated that an unsettling of the idea of worldhistorical teleology, of ideas of a transcendental order, or providence leading to justice, was Proudhon's core political intention. In so doing he undermined the philosophical foundations of statism. Proudhon also questioned the claims made on behalf of science, particularly the way in which it was used to justify a rigidly hierarchical and statist social order.

Proudhon offered the concept of immanence and equilibrium as his alternative. Central to the analytical value of immanence was the idea that morality and the social order were historically shaped by purposive human action. Justice, Proudhon argued, arose when competing forces reached equilibrium. This allowed him to show that transcendental claims to legitimacy made by the church, state or anyone else were foundationless. Indeed, they were actually sustained by force. Therefore, the search for justice was unending and evolved with the discoveries of science, and the needs of society. The key concepts he isolated were "collective force" and "collective reason" - the precise historical nature of which were emergent from historical context and human nature, and remained contingent on both. However, like everyone else he believed a better way of understanding the world was of little value unless it could be institutionalised. The question then became: how was it that statism and "industrial feudalism" had become institutionalised, and was there any hope that Proudhon's own ideas might be realised in the future?

Chapter five demonstrated that the key macro process for this destabilisation and entrenching of particular social norms and institutions was war. In turning to this subject, indeed, in framing the whole issue in the way that he did, Proudhon was following Rousseau, Kant and Comte. However, what Proudhon argued was that war was the primary motor of social change, that preparing for it, financing it and waging it was what had shaped the modern state, and that progress was not inevitable even if the results of wars were generally temporarily right-making. Indeed, right in this context is heavily 
structured by war. Norms of right had seen early manifestations in poetry and religion, both structured heavily by militaristic metaphor and analogy. With the rise of the modern state, these norms become institutionalised by the state through its co-opting of religion, its patronage of the arts, and later by clothing itself in the rhetoric of nationalism.

However, the evolution of war also illustrated a number of other things to Proudhon. First, it illustrated that the way a war was waged was a reflection of the "collective force" and "collective reason" of the society waging it. Secondly, the fact that war was de-facto right-making, illustrated to him that the norms commonly touted to justify the political order were by no means providential, but relied instead on force. Napoleon's defeat illustrated that to Proudhon at least. ${ }^{3}$ Thirdly, seeing wars in this way helped Proudhon understand how inter-social relations have a material and an ideational structure that endures by force. Indeed, all law, Proudhon argued, was upheld and destroyed by force. One might add that the recourse to force by states to uphold law is proof that law has no value other than that which we give it and are willing to tolerate. Proudhon frames this as the "right of force" and by so doing shatters the Kantian edifice. Proudhon argues that this right underpins all others, but is universally ignored because it sits uncomfortably with our ideals of impartiality, peace and order.

What Proudhon argued was that modern socialism had demonstrated that the true source of power resided in labour and in society at large, and that governance ought to be returned to both. When Proudhon turned to the economic realm he repeated arguments he had been making for twenty years. He argued that liberal property relations were not natural, nor were they providential, or particularly liberal. By Proudhon’s analysis, liberal property relations were based on the expropriation of "collective force". Surplus arises from colelctive endeavour. By paying on an individual basis for work that is only productive of profit because of collective endeavour, the capitalist expropriates. Proudhon's critique of French trends was that process was resulting to a new industrial feudalism. and then pocketing the difference. Capitalism was private and legal

\footnotetext{
${ }^{3}$ For a contemporary echo of Proudhon's scorn for Napoleon and the myth that surrounds him, see Taylor [1995].
} 
expropriation of the working class, and this caused ruptures in the economic equilibrium that led to conflict.

French liberalism, on the other hand, was the ideology, or what Proudhon would have called the "collective reason", of property owners. This "collective reason" was supported by a state that had a vested interest in the mutual exploitation of the labour of the working classes and the bourgeoisie for its own ends. The reason the working classes endured this state of affairs was because of ideas of fatalism expounded by the church, ideas of a natural transcendental order and the new 'discoveries' of science which seemed to reinforce these ideas. Proudhon was also awake to the reality that the working classes usually simply want to be left in peace. When dissent was successfully whipped up through the use of nationalism, it too was quickly co-opted by the state to re-legitimise its existence.

Socialism rationalised force in new ways. The concept of "immanent justice”, "collective reason", "mutualism" and "agro-industrial federalism" suggested new ways of legitimising the working class's right of force. If the working class could realise its own political and economic capacity, through the twin promise of mutualism and federalism, this would be a vital first step to realising revolutionary justice. Proudhon's revolutionary theory of justice did two things. Analytically it undermined the claims of the state to autonomy and freedom, illustrated its militarization and destroyed the Kantian conception of law. Normatively, Proudhon's revolutionary theory sought to restrain states and their anarchic interaction through deepened constitutionalism, and empower the working class through agro-industrial federalism and the principle of mutualism.

Proudhon's anarchism was the solution to international anarchy. His preferred federal social order would institutionalise the real and plural social and economic cleavages of any geographical area in a multitude of overlapping ways, but always with the individual and the small social group at its normative heart. The "principle of federation", he believed, would be dynamic enough to accommodate the natural internal changes of a society and strong enough to hold society's "natural groups" together in the face of challenges or shocks. The sheer plurality of the divisions of power and the complexity of 
the institutional arrangements within which power would become exercised was a check on the tyranny of the majority and of despots. He believed, like Rousseau, Kant and innumerable others before them, that justice would be best realised in a pan-European republican federal system.

As John Plamenatz has argued, if Rousseau was the defining figure of early nineteenthcentury France, Proudhon was the key architect of the late nineteenth-century left. Plamenatz closes his work with the following lines:

The revolutionaries of France were never united and they were the devotees, more or less enlightened, of many different creeds. But there were two men, Rousseau and Proudhon, who, more than the others formed their minds. ${ }^{4}$

Read in the light of analyses like this, we can see how well-founded Marx's concerns were. If Marx were to gain the ascendancy in the European working class movement, he needed the state to crush the French left. It did, but ironically it was the French state, led by Proudhon's old Assembly adversary Adolph Thiers - not the Prussians - that massacred nearly 20,000 communards in the Parisian banlieues in 1871. Remarking on the response to the publication of Proudhon's De la Justice, Alexander Herzen, the famous Russian revolutionary and close friend of Proudhon's, remarked at the time that,

The French seek experimental solutions in him, and, finding no plans for the phalanstery nor for the Icarian community, shrug their shoulders and lay the book aside [...] Proudhon is the first of a new set of thinkers. His work marks a transition period, not only in the history of socialism, but also in the history of French logic. ${ }^{5}$

The significance of these words would not be open to us without the context I have provided. But we might also argue that Herzen was perhaps overly hasty in his analysis. Twelve years later Proudhon was indeed the leading figure on the French left, with those

\footnotetext{
${ }^{4}$ Plamenatz [1952], p. 178.

${ }^{5}$ Cited in Jackson [1958], p. 115.
} 
broadly considering themselves to be Proudhonist in some way leading the charge in the First International Workingmen's Association, the Paris Commune, the nascent French syndicalist movement, Spanish republicanism, Russian socialism, anarchism, and more. Indeed, by the early twentieth century Proudhon's thought had begun to break into intellectual and academic circles in the UK and US through the work of Harold Laski, David Mitrany, and others. ${ }^{6}$ The, rise of Bolshevism, the Second World War and the Cold War which followed, deliberately sough to kill it off, and Proudhon's thought dissapeared into the background.

Nevertheless, as Proudhon suggested, the urge for justice is irrepressible. Ultimately, and thankfully, Communism, statism, totalitarianism, fascism, dirigisme and the stark neoliberalism of the Chicago School, have all failed. Positivism has again come under attack and the providentialism of rationalism shown to be prone to atrocities. ${ }^{7}$ And as Proudhon argued with a healthy dose of irony, it seems man's belligerent nature is all that saves him from despotism. ${ }^{8}$

However, it goes without saying that Proudhon's thought is not without flaws. The vast majority are second order contradictions, including the lax use of terminology, some conceptual contradiction, letting rhetoric and polemic get in the way of measured argument, and so on. Many of these flaws can be explained by the fact that he changed his mind over time. He did this because he wrote and published prodigiously for his livelihood, did so in turbulent times, and wrote for a non-academic audience who looked to him for advice. Accounts of these second order flaws can be found in most other analyses of his work and while most of his problematic ideas do little significant damage to his overall theory, his anti-feminism is not one of them.

\footnotetext{
${ }^{6}$ Harold Laski remarked to Justice Oliver Wendell Holmes, right at the start of his illustrious career, that, "I have discovered Proudhon and I want you to share the joy. Really he is immense and he has all the virtues [...] He seems to me to have anticipated most of Karl Marx and to have said it better. He realises the necessity of safeguarding the rights of personality, and at the same time he is not afraid of collective action. He fits gloriously into the scheme of my new book and I'll make him a peg for a bundle of observations. But the main thing is that he will give you some pleasant hours this summer if you can be so tempted." De Wolf Howe [1953], pp. 81-82. Mitrany’s functionalist approach to European federalism owes much to his reading of Proudhon and his critique of Marx. See Mitrany [1951, 1975].

${ }^{7}$ Bauman [1989].

${ }^{8}$ Proudhon [1998b], p. 147.
} 
Proudhon's anti-feminism, as I have discussed at length, is a first order contradiction in his thinking. Proudhon was deeply patriarchal and deliberately ignored opposing arguments so as to maintain what he saw to be a natural order. Here women would be kept in domestic slavery without any political personality or civic role. This position undoubtedly had political roots, and I have shown how a rejection of feminism was also a rejection of the urban, sensualist and pantheistic Saint-Simonians. This movement battled against the conservative, bourgeois and catholic exploitation of urban women, and advocated the dissolution of the family, church and social order. Proudhon presented the nineteenth-century rural ideal of family life as his alternative.

For reasons we may never fully understand, Proudhon presented this ideal as natural and universal, and failed to see the radical inequality and injustice it sustained. He denied that his theory of immanent justice, of emergent equilibrium, of social conflict and social order extended to sexual relations. He believed civic dignity stopped at the hearth and all of this despite being familiar with d'Héricourt's stinging critiques. I illustrated that the collective force of female domestic slavery supported the very patriarchy needed for Proudhon to be able to have the time and luxury to pronounce on such things as the natural sexual order. Moreover, if Proudhon were to be consistent, the sexual antinomy ought to have been seen as equally productive - if not necessarily progressive. The contradictions patriarchy entrenched were clear to feminists for nearly 100 years before Proudhon, and yet it took women's participation in both World Wars, a participation Proudhon thought impossible and undesirable, for the belated consensus in support of universal suffrage across Europe to emerge. What this immanent critique has also shown is that even Proudhon's own ideas were highly conditioned by the moral norms of his time. It also shows that the advancement of universal suffrage, a protracted and painful struggle for justice, has restrained some of the excesses of nineteenth-century patriarchy in spite of Proudhon. It is also worth noting that while some cantons introduced it earlier, universal female suffrage was not granted in Proudhon's beloved Switzerland until 1971, which is no doubt significant; nor was France to see universal suffrage until 1944.

Finally, and bearing this feminist critique in mind, it is arguable that ultimately it is impossible to be a 'Proudhonian' or a 'disciple' of Proudhon unless we accept his anti- 
feminism. His system (despite repeated claims that he had no system, and that his system was simply "justice") is built on a rejection of sexual equality and an extra-scientific, almost deontological defence of the patriarchal family and domestic inequality - no matter how he tried to mollify its effects. I have tried to show how we can use Proudhon's theory to undermine his own ideas, but I do not want to claim that what results is 'Proudhonist' or 'Proudhonism'. This we categorically cannot do. Proudhon was an anti-feminist and if we remain faithful to his ideas then we must remain faithful to these too. My aim has been to reveal something new that we might fashion out of Proudhon's ideas, but it is categorically not Proudhonism. Therefore, in conclusion, a full re-working of Proudhon's ideas for the modern era would probably require another thesis.

\section{Proudhon and Contemporary IR Theory?}

This thesis had two main claims to originality. The first was to provide the missing exegesis of Proudhon's theory of world politics. This has now been presented and summarised. The second was to use this summary to tell the story of the political and social evolution of the nineteenth century and contribute to our understanding of the origins of the twentieth. This too has now been completed. So what is the contribution of this thesis to IR theory? The answer I would like to suggest is not to some particular question or other. Rather, I want to suggest that the thesis makes us think about why Proudhon is not already part of the canon. Why is there no anarchist IR theory? My concluding comments will now illustrate why IR sees the world the way it does and, by so doing, provide an explanation for Proudhon's absence. This will of course double as a demand for anarchism's inclusion.

What I will do next is briefly survey the standard historiography of IR theory. This is possible in such a short space because very little such historiography exists. I first turn to Martin Wight's influential essay 'Why is there no International Theory?', before I discuss Stanley Hoffmann’s ‘An American Social Science: International Relations’. I then briefly turn to the recent work of Brian Schmidt to illustrate the German origins of modern US IR theory. These three works illustrate why it is that IR has historically been the servant 
of the state. Contemporary breaks with tradition can be seen in the debate between Booth and Smith and Lord William Wallace about the place of policy relevant research in IR. Both the historiography and the proximity of mainstream IR to the state make it very difficult for IR theorists to take anarchism seriously, and this, I will suggest, is dangerous, unscientific, and evidence of clear intellectual prejudice. ${ }^{9}$

Martin Wight's 'Why is there no International Theory?' (1966) has assumed canonical status in IR theory. ${ }^{10} \mathrm{He}$ argued that the obvious reason for the absence of International Theory in the pre-1945 period was because it was simply impossible to write. By contrast, political theory involved the search for the good life within states and had flourished as a body of literature for millennia. Since no overarching authority exists in the international sphere, to search for the good life here is chimerical. Wight famously argued that the international system is one of "recurrence and repetition", where conflict and attitudes to international society remain constant. International theory is impossible because there's nothing to speculate about - its recurrent realities of war and conflict are plain for all to see.

Where snippets of international theory were penned, Wight argues, it invariably came under the title of "the philosophy of history" and, he concluded that it is but a small step from here to "theodicy". ${ }^{11}$ My analysis supports this contention as far as Rousseau, Kant and Comte were concerned, but not for Proudhon. However, Wight's influential essay also entrenched the idea that no pre-1945 international theory exists. "The only political philosopher who has turned wholly from political theory to international theory is Burke" he argued, moreover, "[t]he only political philosopher of whom it is possible to argue whether his principal interest was not in the relations between states rather than - or even more than - the state itself, is Machiavelli."12 Burke, the classic anti-revolutionist and Machiavelli the arch realist, both insisted on the immutability of the international system, an intransigence Wight also believed in. ${ }^{13}$ For Wight, the purpose of IR theory in the

\footnotetext{
${ }^{9}$ Numerous others have made similar arguments, but never in the same way. See, for example, Smith [2004].

${ }^{10}$ Wight [1966].

${ }^{11}$ Ibid., p. 33.

${ }^{12}$ Ibid., p. 20.

${ }^{13}$ Ibid.
} 
post-War period was to speculate on the best means to manage inter-state rivalries in the nuclear system. Wight added that we ought to follow diplomatic tradition since, while the pieces may have moved, the essential characteristics and tendencies of states and men can not progress.

Wight was wrong on both counts: there was pre-War international theory, however, as Proudhon argued, progress would only be possible if states were emasculated. Nevertheless, Wight's work helped galvanise an approach to international politics that was historical (if only in so far at it was taxonomy), and saw the society of states as governed by diplomatic principles and rules which ought to be protected. This fitted comfortably with British post-War ambitions, but was not strong enough to resist the eventual hegemony of US social scientific approaches to world order.

In 'An American Social Science: International Relations’ (1977), the Viennese émigré to the US, Stanley Hoffmann, gave IR practitioners a far more empirically rich account of the particular shape of post-war IR theory. ${ }^{14}$ Hoffmann also began by arguing that no extended treatment of international politics existed prior to the Second World War. Hoffmann was surely familiar with Proudhon's work, but perhaps because of being heavily involved with Alan Ritter's work on Proudhon all the way through the sixties, believed he had grounds to ignore it. ${ }^{15}$ However, Hoffmann made two important contributions to the debate. First, IR became an American social science because postWar US hegemony in world politics gave it the means to fund domestic research in its own interests. Secondly, given the absence of a canon of international theory that was applicable to the concerns of nuclear Cold War rivalry, IR was inevitably going to flower here. Hoffmann argues that American social science generally evolved through Weber to Talcott Parsons, via Morgenthau and Waltz. What both the latter theorists offered was testable propositions that could be developed into coherent theory and applied to contemporary international problems.

\footnotetext{
${ }^{14}$ Hoffmann [2000].

${ }^{15}$ See Ritter [1969], p. v. However, Hoffmann draws our attention to Raymond Aron's seminal work of political sociology in its application to the Cold War, a text which has a relatively extensive engagement with Proudhon’s thought. See, Aron [1966], pp. 600-610.
} 
Two further things were also needed in order to cement US hegemony in the discipline. The first was the tendency to abandon concepts of universal truth, and the normative ideals of political theory, in favour of the legitimacy claims of a value-free science. Science promised to solve the problem of conflict without the need for the messy problem of values and politics. This also helped provided a veneer of disinterested legitimacy in the policy advice that flowed from the IR community in the US. The second, perhaps more significant trend was the tendency to tailor this value-free science to the policy interests of US policy makers. This, Hoffman lamented, resulted in the “precious relays” between academy and policy makers.

International theorists tended to do two things: the first was to emphasise the law-like continuities within world politics. This helped establish the importance of a scientific methodology in uncovering these continuities. It also gave academics something exclusive to sell. Secondly, this ensured that science would always be of value to the US state since it had an interest in sustaining its hegemony - or at least resisting any change in the status quo. Value-free science that might help legitimise this order was highly prized and widely developed as 'structural realism'. Hoffmann's plea that IR theorists turn to history and sociology was not widely heeded. ${ }^{16}$

Hoffmann and Wight's way of framing the discipline has been accurate in some senses, but hugely misleading in others. One does not only have to recognise the universal ignorance of the works of Proudhon to understand that their knowledge is partial, nor simply accept their statist conclusions to understand why. Moreover, Brian Schmidt ${ }^{17}$ has shown that there is a distinct continuity between nineteenth-century academic concerns regarding the international system and twentieth-century analysis. By going back to the detail of academic programmes in the US, he has shown that Weber may have been significant, but US political science departments were overwhelmingly German in terms of their personnel and their world-views without his influence.

\footnotetext{
${ }^{16}$ Ibid., p. 97.

${ }^{17}$ Schmidt [1998].
} 
German idealist theories of the state dominated the problem field of political science at the close of the nineteenth century. The problem they inherited from Hobbes, Rousseau, Kant and Hegel was what to do about the international anarchy this way of seeing the world created. Moreover, what ought to be done about the stateless areas of the world? For nearly one hundred years, philosophers and professional academics provided theoretical and philosophical justifications for colonialism, or could be found simply "fiddling with concepts while the world burned" as Donald Puchala put it. ${ }^{18}$ The aim was to create states where no such thing had previously existed, so as to guarantee that international law could have binding force there, and so that savage communities could eventually realise "the objectively revealed will of God". This was how Heinrich Von Treitschke saw it, and it is significant that he was the influential teacher of two early figures in the late nineteenth and early twentieth century establishment of academic discipline of political science in the US. ${ }^{19}$ Indeed, in a rare piece of political rather than discursive contextualisation, Schmidt notes that in the pre-1914 era key writers in the development of US academic IR, such as David Hill, were part of the US diplomatic service or ambassadors themselves. ${ }^{20}$ Schmidt shows that Hoffmann's chronology is incorrect, even if his analysis is not. From the outset, there has been no major distinction between the interests of science and the interests of states. ${ }^{21}$

Schmidt analyses what he calls the "internal discursive development"22 of IR. Because of this methodology, the evolution of IR is understood on its own terms, which, while admirable, in this case results in political myopia. ${ }^{23}$ Schmidt would probably not contest the fact that the problems these later scholars engaged with stretched back as far as (if not further than) the period this thesis has sought to uncover. But we need to recognise that the shift towards Prussian preponderance in the European balance of power also seemed to give German scholars added kudos in the US. This emigration was repeated in the run up the Second World War. For example, while Morgenthau left Germany for the US to escape the Nazis, he nevertheless brought much Weimar ideology with him. As Kenneth

\footnotetext{
${ }^{18}$ Puchala [1998].

${ }^{19}$ Schmidt [1998], p. 64-69.

${ }^{20}$ Schmidt [1998], pp. 92-93.

${ }^{21}$ Cf. Anghie [2005].

${ }^{22}$ Schmidt [1998], p. 1.

${ }^{23}$ Cf. Puchala [1998].
} 
Waltz, another second generation US German once remarked in an interview: "I have often said that what Morgenthau did was translate Meinecke from German to English, and if you look at the index, you won't see Meinecke mentioned."24 Moreover, Morgenthau's debt to the Nazi ideologue Carl Schmitt is often highlighted as being central to his critique of inter-war liberalism. ${ }^{25}$

As a result of Schmidt's internal discursive approach to IR, its totalitarian legacy is never engaged with sufficiently at a disciplinary level. ${ }^{26}$ But this totalitarian legacy of IR is hidden in plain sight. By reflecting on the absence of anarchism, we can see that IR has been bewitched by the state. This is important since when it came to the extension of the "Wilsonian" or idealist paradigm in international affairs in the inter war years, it was fully consistent with entrenching Great Power dominance in world affairs. ${ }^{27}$ The type of utopianism Carr criticised was the product of hard-nosed imperialistic success, and the desire to entrench a system of states that was hugely beneficial to the post-war US hegemony. Thus, statism in IR, as both a normative principle of political action and as an ontological framing of world affairs, is so deeply enmeshed with the interests of the state as to become virtually indistinguishable from it.

Thankfully, things have begun to change in the past twenty five to thirty years. Gerard Holden makes two excellent points in this regard. First, the key milestones in academia are the pluralisation of university graduates to include women, and the working class in the 1960s and 1970s, which corresponded with radical protest and seismic shifts in popular culture that eroded the grip of the old order, hopefully forever. The second key social indicator of change was the distancing of broad sections of the radical left and its intellectuals from orthodox Marxism, and the slow decline in membership of European Communist Parties during the same period. ${ }^{28}$

\footnotetext{
${ }^{24}$ Halliday and Rosenburg [1998], p. 386.

${ }^{25}$ See, for example, Scheuerman [1999], Williams [2005]. For a good analysis of Schmitt's politics and ideas see, for example, Wolin [1990, 1992]. An excellent example of Morgenthau's replication of Schmitt's arguments can be found in their mutual critiques of the pluralist Harold Laski. Schmitt [1999], cf. Morgenthau [1962].

${ }^{26}$ One important exception is Honig [1996].

${ }^{27}$ Carr [2001]

${ }^{28}$ Holden [2002], pp. 266-267.
} 
The re-emergence of both feminism and 'post'-modern theory is usefully understood against this backdrop. Feminists rightly rubbished the patriarchal Marxist reductionism of all social inequality to class, while all but the most hardened Marxists tired of the ideological support for any and all atrocities committed in the name of Communism. Critical theory in IR has its roots here. However, while it has now abandoned the less palatable aspects of Marxism and left wing social praxis, it has largely retained its reading of history. As such, anarchism continues to be ignored. The assumption being that anarchists simply do not understand the nature of social reality, and are unable to attract any followers except in 'backward' parts of the world (as Marxists often so eloquently put it). Of course, the real history of systematic marginalisation of the anarchists in the International Workingmen's Association conferences, then the extermination of the anarchists by the Bolsheviks in revolutionary Russia and later in Spain, not to mention propaganda wars, has sufficed to bury a more faithful memory of anarchism. Feminists rightly ignore early anarchism and have done just fine without it. Perhaps a broader rapprochement is still in order.

Today, debates about what IR theory is for revolve around a number of things: the advancement of science, the illumination of history, policy relevance, or social and individual emancipation. As discussed in some detail in the introduction to this thesis, critical theorists such as Andrew Linklater have come to articulate a vision of international theory that rejects the hubris of positivism, the amorality of an ethic of interests, claims to the structural immutability of the international system or human nature and the overly narrow focus on class, production or materialism. ${ }^{29}$ These are clear echoes of Proudhon, but for Linklater to get to this point, some of the central aspects of European political thought first had to be rejected or reformed.

However, perhaps because of the absence of anarchism, and despite Linklater's work, what remains largely unquestioned in the mainstream of IR theory, bar one or two notable exceptions, is the service IR ought to render to the state. As the polemical and heated debate between Lord William Wallace, Steve Smith and Ken Booth, in the late

\footnotetext{
${ }^{29}$ Linklater [1996]
} 
1990s illustrated, ${ }^{30}$ while the needs of the state are no longer obvious, it is not clear that the public's needs necessarily chime with those of their nominally representative states either. ${ }^{31}$ The events of the twentieth century, from civil rights activism to state executed and/or state sponsored genocide, illustrate this neatly. Who serves who is a perennial political problem, but despite their disagreements, Wallace, Booth and Smith talk of "striking the right balance" between policy advice and critical academic work, ${ }^{32}$ with all three advocating a type of detached engagement with the state. But Smith also asks how it is possible to "speak truth to power" when the very concept of truth in this context is already structured by power. Smith asserts that this structuring of truth is the product of the discipline's favoured rationalist epistemology and because of many academic's positions within the policy-making elite of any given country. "Surely", he concludes,

the task of academics is to show how these very relationships between truth and power, and between empirical and the theoretical, operate. That, rather than the search for influence within the policy-making community, is the ultimate ethical and political engagement with the civil society in which we work and to which we are responsible. ${ }^{33}$

But how far can this go? As far as anarchism? My guess is only an insignificant few will venture that far. History is arguably the most important tool in the box for sustaining this analysis. From Proudhon's time to the present, indeed, from as far back as Plato's Republic, political thought has been the servant of political practice and it has invariably been conducted within systems of exploitation and hierarchy that are themselves justified by recourse to the same theory. Yet, at no time in history has anything as anti-statist as Proudhon's political theory been as clearly and extensively argued. Its absence in IR theory is completely unjustified but wholly explicable.

However, the state does not always listen to mainstream IR theorists. In fact states only listen if the advice serves their interests. For example, Carr spent most of his life in the

\footnotetext{
${ }^{30}$ See Booth [1997], Smith [1997].

${ }^{31}$ Booth [1997], p. 375.

${ }^{32}$ Ibid., pp. 376-377.

${ }^{33}$ Smith [1997], p. 516.
} 
Foreign Ofiice and promoted the policy of appeasement which was heeded and then ignored; Morgenthau wrote extensively against the Vietnam war; Waltz opposed both Iraq wars, while the realist John Mearsheimer has written and spoken against the US state and its universities bowing to the pressure of the Jewish lobby. Traditionally conservative realists now campaign collectively against the current Iraq war, with members of the 'Coalition for a Realistic Foreign Policy' coming from across the mainstream US academic IR community. ${ }^{34}$ Individual IR theorists are not complicit in modern disaster, but as a discipline and as vital cogs in the production of knowledge and power, we are structurally enmeshed in the western praxis of modern capitalism and state sovereignty. ${ }^{35}$ If unacknowledged, then we remain complicit in the disasters that flow there from.

In the past twenty five years, critical theorists have taken important steps to highlight and explain this structural complicity, and my contribution here has only been partial. More work needs to be done - this much is clear. Perhaps a return to Proudhon and his times would be a good place to start. This would not be any guarantee of success of course. But if we want to change the world, and history shows that it is indeed malleable, we need to know how it came to be the way it is, and what our options now are. We need to listen for the echoes of past thinkers and see how the acoustics of modern life have shaped their messages. Proudhon's works on European and world politics are, in this respect, a far better place to start than the vast majority of post-war IR theory, and the reason for this is the distance his anarchism gives us from the state. Proudhon's international theory may not be able to contribute to this or that analytical problem in IR theory, but it should have little difficulty contributing to emancipatory social praxis as such. If we must remain within the confines of the discipline, we should recognise that anarchism is singularly capable of speaking truth to power since it is the only political ideology that does not seek state power itself. This, I believe, is the mark of political integrity, and I hope that my critique of Proudhon’s anti-feminism supports my own.

\footnotetext{
${ }^{34}$ Coalition [2004].

${ }^{35}$ Smith [2004].
} 


\section{Bibliography}

Albert, Michael [2003] Parecon: Life After Capitalism, London, Verso.

Albert, Michael \& Hahnel, Robin [1991] The Political Economy of Participatory Economics, Princeton, Princeton University Press.

Allen, Mary B. [1952] 'P.J. Proudhon in the Revolution of 1848', The Journal of Modern History, 24, 1-14.

Alliez, Eric \& Negri, Antonio [2003] 'Peace and War', Theory, Culture and Society, 20:2, 109-118.

Amoudruz, Madeleine [1945] Proudhon et l'Europe. Les Ideés de Proudhon en Politique Étrangère, Paris, Éditions Domat Montchrestien.

Anderson, Benedict [1991] Imagined Communities: Reflections on the Origin and Spread of Nationalism, London, Verso.

--- [2005] Under Three Flags: Anarchism and the Anti-Colonial Imagination, London, Verso.

Anghie, Anthony [2005] Imperialism, Sovereignty, and the Making of International Law, Cambridge, Cambridge University Press.

Ansart, Pierre [1969] Marx et l'Anarchisme: Essai sur les Sociologies de Saint-Simon, Proudhon et Marx, Paris, Presses Universitaires de France.

--- [1970] Naissance de l'Anachisme: Esquisse d'une Explication Sociologique du Proudhonisme, Paris, Presses Universitaires de France.

--- [1992] 'La Présence du Proudhonisme dans les Sociologies Contemporaines’. Mil

Neuf Cent: Revue d'Histoire Intellectuelle, 10, 94-110.

--- [1997] 'Proudhon À Travers Le Temps', L’Homme et Société, 123-124, 17-24.

Archer, Margaret. S [1995] Realist Social Theory: The Morphogenetic Approach, Cambridge, Cambridge University Press.

Aron, Raymond [1966] Peace and War: A Theory of International Relations, New York, Doubleday.

--- [1968] Main Currents in Sociological Thought 1: Montesquieu, Comte, Marx, Toqueville: The Sociologists and the Revolution of 1848, New York, Doubleday. 
Ashley, Richard K. [1984] 'The Poverty of Neorealism’, International Organization, $38: 2,225-286$

--- [1988] 'Untying the Sovereign State: A Double Reading of the Anarchy

Problematique’, Millennium: Journal of International Studies, 17:2, 227-262.

--- [1989] 'Imposing International Purpose: Notes on a Problematic of Governance’, in

Czempiel, Ernst-Otto \& Rosenau, James N. (Eds.) Global Changes and

Theoretical Challenges: Approaches to World Politics for the 1990s, Cambridge

Mass., Lexington, 251-290.

Ashley, Richard K. \& Walker, R.B.J. [1990] 'Speaking the Language of Exile: Dissident

Thought in International Studies’, International Studies Quarterly, 34, 259-268.

Ashworth, Lucian. [2006] 'Where are the Idealists in Interwar International Relations?',

Review of International Studies, 32, 291-308.

Baggiani, Julian [2007] 'Sacré Bleu’, Times Higher Education Supplement, August 3.

Bakunin, Mikhail [1970] God and the State, New York, Dover Publications.

--- [1990] Statism and Anarchy, Cambridge, Cambridge University Press.

Baldwin, D. A. (Ed) [1993] Neorealism and Neoliberalism: The Contemporary Debate, New York, Columbia University Press.

Barbalet, J. M. [1988] Citizenship, Milton Keynes, Open University Press.

Barnard, F.M. \& Vernon, Richard [1975] 'Pluralism, Participation, and Politics:

Reflections on the Intermediate Group’, Political Theory, 3:2, 180-197.

Barry, Brian M. [1995] Justice as Impartiality, Oxford, Clarendon Press.

Bauman, Zygmunt [1989] Modernity and the Holocaust, Ithaca, N.Y., Cornell University Press.

Becker, Jean-Jaques [2004] 'La Gauche et l’Idée de la Guerre’, in Becker, JeanJaques \& Candar, Gilles (Eds.) Histoire des Gauches en France: Volume 1, L’Héritage du XIXe Siècle, Paris, La Découverte, 522-530.

Beecher, J \& Bienvenu, R [1971] 'Introduction’, in Beecher, J \& Bienvenu, R (Eds.) The Utopian Vision of Charles Fourier: Selected Texts on Work, Love and Passionate Attraction, Boston, Beacon Press.

Beitz, Charles [1979] 'Bounded Morality: Justice and the State in World Politics', International Organisation, 33:1, 404-424. 
Beitz, Charles R. [1979] Political Theory and International Relations, Princeton, Princeton University Press.

--- [1989] Political Equality: An Essay in Democratic Theory, Princeton, Princeton University Press.

Bell, David A. [2001] The Cult of the Nation in France: Inventing Nationalism, 16801800, Cambridge Mass., Harvard University Press.

Bell, D. S. A. [2003] 'Political Theory and the Functions of Intellectual History: A Response to Emmanuel Navon', Review of International Studies, 29, 151-160.

Berghahn, Volker R. [1981] Militarism: The History of an Intellectual Debate 18611971, Leamington Spa, Berg Publishers.

Berth, Édouard [1912] 'Proudhon En Sorbonne', L’Indipéndence, 27, 122-140.

Bhaskar, Roy [1989] The Possibility of Naturalism: A Philosophical Critique of the Contemporary Human Sciences, London, Routledge.

Black, Anthony [1997] 'Christianity and Republicanism: From St. Cyprian to Rousseau’, The American Political Science Review, 91:3, 647-656.

Bobbitt, Philip [2002] The Shield of Achilles: War, Peace, and the Course of History, New York, Alfred A. Knopf.

Booth, Ken. [1997] 'Discussion: a reply to Wallace’, Review of International Studies, 23, 371-377.

--- [2000] 'Security in Anarchy: Utopian Realism in Theory and Practice.' In Linklater, Andrew (ed) International Relations: Key Concepts in Political Science, London, Routledge, 322-341.

Boucher, David [1998] Political Theories of International Relations: From Thucydides to the Present, Oxford, Oxford University Press.

Boucher, David \& Kelly, Paul (Eds.) [1998] Social Justice from Hume to Walzer, London, Routledge.

Bougle, Célestin (Ed.) [1911] La Sociologie de Proudhon, Paris, Armand Colin.

--- [1920] Proudhon et Notre Temps, Paris, Editions \& Librairie.

--- [1951] Socialismes Français: Du "Socialisme Utopique" à la "Démocratie Industrielle", Paris, Armand Colin. 
Bouglé, Celestin and Cuvillier, A. [1927] 'Introduction’ in Proudhon, Pierre-Joseph., De la Création de l'Ordre dans l'Humanité ou Principes d'Organisation Politique, Paris, Marcel Rivière.

Bourgeois, Nicolas [1927] Les Théories du Droit International chez Proudhon: Le Fédéralisme et la Paix, Paris, Marcel Rivière.

Brinbaum, Pierre [1992] Anti-Semitism in France: A Political History from Léon Blum to the Present, Oxford, Basil Blackwell.

Brown, Chris [1992] International Relations Theory: New Normative Approaches, Hemel Hempstead, Harvester Wheatsheaf.

--- [2002] Sovereignty, Rights and Justice: International Political Theory Today, Cambridge, Polity.

Brown, Chris, Nardin, Terry \& Rengger, N. J. (Eds) [2002] International Relations in Political Thought: Texts from the Ancient Greeks to the First World War, Cambridge, Cambridge University Press.

Burgess, Michael [2004] 'Federalism’ in Wiener, Antje and Diez, Thomas (Eds) European Integration Theory, Oxford, Oxford University Press, 25-43. Burguière, André \& Revel, Jacques (Eds.) [1990] L'État et les Conflits, Paris, Seuil. Buzan, Barry \& Little, Richard [2001] 'Why International Relations Has Failed as an Intellectual Project and What to Do About It', Millennium: Journal of International Studies, 30:1, 19-39.

Cabanel, Patrick [2004] 'La Gauche et l’Idée Nationale’, in Becker, Jean-Jaques \& Candar, Gilles (Eds.) Histoire des Gauches on France: Volume 1, l'Héritage Du XIXe Siècle, Paris, La Découverte, 506-521.

Camilleri, Joseph A. \& Falk, Jim [1992] The End of Sovereignty? The Politics of a Shrinking and Fragmenting World, Aldershot, Edward Elgar.

Canto-Sperber, Monique [2004] 'Proudhon, the First Liberal Socialist', Presented at The Gimeon Conference on French Political Economy 1650-1848. Stanford University. http://reserves.stanford.edu/depts/hasrg/frnit/pdfs_gimon/canto.pdf Accessed 25/09/07.

Carr, E. H. (1937) Michael Bakunin, London, Macmillan \& Co.

--- [1950] 'Proudhon: The Robinson Crusoe of Socialism', in Carr, E. H. (Ed.) Studies in Revolution, London, Macmillan, 38-55. 
--- [2001] The Twenty Years' Crisis, 1919-1939: An Introduction to the Study of International Relations, (2nd Ed). Cox, Michael (Ed.), Basingstoke, Palgrave.

Cassirer, Ernst [1963] The Question of Jean-Jacques Rousseau, Bloomington, Indiana University Press.

Cassirer, Ernst [1963] Rousseau, Kant and Goethe, New York, Harper Torchbooks. Chambost, Sophie [2004] Proudhon et la Norm: Pensé Juridique d'un Anarchiste, Rennes, Presses Universitaires de Rennes.

Charle, Christophe [1994] A Social History of France in the 19th Century, Oxford, Berg. Chesters, G. \& Welsh, I. [2005] 'Complexity and Social Movement(s): Process and Emergence in Planetary Action Systems', Theory, Culture \& Society, 22:5, 187211.

Chomsky, Noam [2003] 'Commentary: Moral Truisms, Empirical Evidence and Foreign Policy', Review of International Studies, 29, 605-620.

Christian, R. F. [1969] Tolstoy: A Critical Introduction, London, Cambridge University Press.

Churchill, Ward \& Ryan, Mike [1998] Pacifism as Pathology: Reflections on the Role of Armed Struggle in North America, Winnipeg, Arbeiter Ring Publishing.

Clark, Ian [2003] 'Legitimacy in a Global Order', Review of International Studies, 29, 75-96.

Clausewitz, Carl Von [1997] On War, Herts, Wordsworth.

Coalition for a Realistic Foreign Policy [2004] http://www.realisticforeignpolicy.org/static/000027.php. Accessed, 25:03:2008

Cohn, Jesse \& Wilbur, Sean [2001] 'What's Wrong with Postanarchism?' The Institute of Anarchist Studies, http://www.anarchist-studies.org/article/articleview/26/1/1 Accessed 31/08/03.

Colson, Daniel [2001] Petit Lexique Philosophique de l'Anarchisme: De Proudhon à Deluze, Paris, Librairie Général Française.

Comte, Auguste [1968] System of Positive Polity, (IV Vols. a, b, c, d) New York, Burt Franklin.

--- [1998a] 'Plan of the Scientific Work Necessary for the Reorganisation of Society', in Jones, H. S. (Ed.) Comte: Early Political Writings, Cambridge, Cambridge University Press, 47-144. 
--- [1998b] 'Summary Appraisal of the General Character of Modern History', in Jones, H. S. (Ed.) Comte: Early Political Writings, Cambridge, Cambridge University Press, 5-46.

--- [1998c] 'Philosophical Considerations on the Sciences and Scientists', in Jones, H. S.

(Ed.) Comte: Early Political Writings, Cambridge, Cambridge University Press, 145-186.

--- [1998d] 'Considerations on the Spiritual Power', in Jones, H. S. (Ed.) Comte: Early

Political Writings, Cambridge, Cambridge University Press, 187-227.

Copley, Antony [1989] 'Pierre-Joseph Proudhon: A Reassessment of His Role as a

Moralist', French History, 3:2, 194-221.

Cox, Michael (Ed.) [2000] E. H. Carr: A Critical Appraisal, Basingstoke, Palgrave Macmillan.

Cox, Robert [1996] 'Social Forces, States and World Orders: Beyond International

Relations Theory', in Cox, Robert \& Sinclair, Timothy (Eds.) Approaches to

World Order, Cambridge, Cambridge University Press, 85-123.

Crankshaw, Edward [1974] Tolstoy: The Making of a Novelist, London, Weidenfeld and Nicolson.

Creighton, Colin \& Shaw, Martin [1987] The Sociology of War and Peace, Basingstoke, Macmillan.

Dark Star Collective [2002] Quiet Rumors: An Anarcha-Feminist Reader, Edinburgh, AK Press.

Darling, John \& Pijpekamp, Maaike Van De [1994] 'Rousseau on the Education,

Domination and Violation of Women', British Journal of Educational Studies, 42:2, 115-132.

Darriulat, Phillipe [2001] Les Patriotes: La Gauche Républicaine et la Nation 18301870, Paris, Éditions Du Seuil.

Davies, Norman [1981] God's Playground: A History of Poland Oxford, Clarendon Press.

Davis, Rufus [1978] The Federal Principle: A Journey through Time in Quest of a Meaning, London, University of California Press.

De Lubac, Henri [1948] Un-Marxian Socialist: A Study of Proudhon, London, Sheed and Ward. 
Despland, Michel [1973] Kant on History and Religion, with a Translation of Kant's 'on the Failure of All Attempted Philosophical Theodicies', Montreal, McGill Queen's University Press.

Devetak, Richard [1995] 'The Project of Modernity and International Relations Theory', Millennium: Journal of International Studies, 24:1, 27-53.

De Héricourt, Jenny [1981] A Woman's Philosophy of Woman or, Woman Affranchised: An Answer to Michelet, Proudhon, Girardin, Legouvé, Comte, and Other Modern Innovators, Westport, Hyperion Press.

De Wolfe Howe, Mark. (Ed.) [1953] Holmes-Laski Letters: The Correspondence of Mr. Justice Holmes and Harold J. Laski. 1916-1935, London, Oxford University Press.

Dillard, Dudley [1942] ‘Keynes and Proudhon’, Journal of Economic History, 2, 63-76.

Dolléans, Édouard [1948] Proudhon, Paris, Gallimard.

Donelan, Michael [1990] Elements of International Political Theory, Oxford, Clarendon Press.

Doppelt, Gerald [1978] 'Walzer’s Theory of Morality in International Relations', Philosophy and Public Affairs, 8:1, 3-26.

Durkheim, Emile [1984] The Division of Labour in Society, London, Macmillan.

Dunne, T. [1998] Inventing International Society: A History of the English School, Houndmills, Macmillan in association with St. Antony's College, Oxford.

Dyer, Gwynne [1986] War, London, Guild Publishing.

Edwards, Stewart (Ed.) [1969] Selected Writings of Pierre-Joseph Proudhon, London, Macmillan.

Eikhenbaum, Boris [1982] Tolstoy in the Sixties Michigan, Ardis.

Ellenburg, Stephen [1982] 'Rousseau and Kant: Principles of Political Right', in Leigh, R. A. (Ed.) Rousseau after 200 Years: Proceedings of the Cambridge Bicentenial Colloquium. Cambridge, Cambridge University Press, 3-22.

Endo, Ken [1994] 'The Principle of Subsidiarity: From Johannes Althusius to Jacques Delors', Hokkaido Law Review, 44:6, 2064-1965.

Engels, F. [1993] Socialism: Utopian and Scientific, London, Bookmarks.

Epstein, Barbara. (2001) Anarchism and The Anti-Globalisation Movement Monthly Review, 53:4, 1-14. 
Enloe, Cynthia H. [1989] Bananas, Beaches and Bases: Making Feminist Sense of International Politics, Berkeley, University of California Press.

Falk, Richard [1979] ‘Anarchism and World Order’, in Pennock, J. Roland \& Chapman, John (Eds.) Nomos XIX: Anarchism, New York, New York University Press, 6387

Fauré, Christine [1991] Democracy Without Women: Feminism and the Rise of Liberal Individualism in France, (Translated by Calaudia Gorbman and John Berks), Bloomington, Indiana University Press.

Fedorowicz, J. K. (Ed.) [1982] A Republic of Nobles: Studies in Polish History to 1864, Cambridge, Cambridge University Press.

Fehér, Ferenc [1987] The Frozen Revolution: An Essay on Jacobinism, Cambridge, Cambridge University Press.

Feyerabend, Paul [1975] Against Method: Outline of an Anarchistic Theory of Knowledge, London, NLB.

Föllesdal, Andreas [1998] 'Survey Article: Subsidiarity’, The Journal of Political Philosophy, 6:2, 190-218.

Forbes, Amy Wiese [2001] '"Let’s Add the Stomach": Satire, Absurdity, and July Monarchy Politics in Proudhon’s What Is Property?’ French Historical Studies, 24:4, 679-705.

Foucault, Michel [2003] Society Must Be Defended, London, Penguin.

Fourier, Charles [1996] Theory of the Four Movements, Cambridge, Cambridge University Press.

Fralin, Richard [1978] Rousseau and Representation: A Study of the Development of His Concept of Political Institutions, New York, Columbia University Press.

Franks, Benjamin [2006] Rebel Alliances: The Means and Ends of Contemporary British Anarchisms, Edinburgh, AK.

Friedrichs, Jörg [2001] 'The Meaning of New Medievalism', European Journal of International Relations, 7:4, 475-502.

Gadamer, Hans Georg [1989] Truth and Method, London, Sheed \& Ward.

Gane, Mike [2006] Auguste Comte, Abingdon, Routledge.

Gay, Peter [1969] The Enlightenment, an Interpretation. Vol 2: The Science of Freedom, London, Weidenfeld and Nicholson. 
Gemie, Sharif [1996] 'Anarchism and Feminism: A Historical Survey’, Women’s History Review, 5:3, 417-44.

George, Jim [1995] 'Realist ‘Ethics’, International Relations and Post-Modernism:

Thinking Beyond the Egoism-Anarchy Thematic' Millennium: Journal of International Studies, 24:2, 195-225.

George, William H. [1922] 'Proudhon and Economic Federalism', The Journal of Political Economy, 30:4, 531-542.

Giddens, Anthony [1995] A Contemporary Critique of Historical Materialism, London, Macmillan.

Gordon, Uri [2007] Anarchy Alive! Anti-authoritarian Politics from Practice to Theory, London, Pluto Press.

Gould, Carol C. [1978] Marx’s Social Ontology: Individuality and Community in Marx’s Theory of Social Reality, Cambridge Mass, MIT Press.

Gould, Stephen J. [1988] 'Kropotkin Was No Crackpot’, Natural History, 97, 12-21. Gourevitch, Victor [2001] 'The Religious Thought', in Riley, Patrick (Ed.) The Cambridge Companion to Rousseau, Cambridge, Cambridge University Press, 193-246.

Graeber, D. [2002] 'The New Anarchists', New Left Review, 13, 61-73.

Grayling, A. C. [2006] 'Reasonable Bounds’, New Humanist.

http://www.newhumanist.org.uk/Volume121issue4_comments.php?id=P2082_0_ 43_0_C Accessed 10/11/06.

Grenville, J. A. S. [1976] Europe Reshaped: 1848-1878, Hassocks, Fontana.

Grogan, Susan K [1992] French Socialism and Sexual Difference: Women and the New Society, 1803-44, London, Macmillan.

Guérin, Daniel [1978] Proudhon Oui \& Non, Paris, Gallimard.

Gurvitch, Georges [1947] Sociology of Law, London, Routledge and Keegan Paul.

--- [1965] Proudhon: Sa Vie, son Oeuvre avec un Exposé de sa Philosophie, Paris,

Presses Universitaires de France.

--- [1967] 'Proudhon et Marx', in Doucy, Arthur (Ed.) L'Actualité de Proudhon:

Colloque de Novembre 1965. Brussels, Editions de l’Instutut de Sociologie de l’Université Libre de Bruxelles, 89-97.

--- [1971] The Social Frameworks of Knowledge, Oxford, Basil Blackwell. 
Guy-Grand, Georges [1911] La Philosophie Syndicaliste, Paris, Bernard Grasset.

Guy-Grande, Georges [1947] Pour Connaitre la Pensée de Proudhon, Paris, Bordas.

Guzzini, Stephano [1998] Realism in International Relations and International Political

Economy: The continuing story of a death foretold, London, Routledge.

Halévy, Daniel \& Sainte-Beuve, Charles Augustin [1948] La Vie de Proudhon, Paris,

Stock.

Halliday, Fred and Rosenberg, Justin [1998], 'Interview with Ken Waltz’ Review of International Studies, 24: 371-386.

Hall, Constance Margaret [1971] The Sociology of Pierre-Joseph Proudhon 1809-1865,

New York, Philosophical Library.

Halperin, Sandra [2004] War and Social Change in Europe: The Great Transformation

Revisited, Cambridge, Cambridge University Press.

Hampsher-Monk, Iain [1992] A History of Modern Political Thought: Major Political

Thinkers from Hobbes to Marx, Oxford, Blackwell.

Hanssen, Beatrice [2000] Critique of Violence: Between Poststructuralism and Critical Theory, London, Routledge.

Harbold, William, H. [1969] 'Justice in the Thought of Pierre-Joseph Proudhon', Western Political Quarterly, 22:4, 723-741.

--- [1969] 'Progressive Humanity in the Philosophy of P.-J. Proudhon', Review of

Politics, 31:1, 28-47.

Haddock, Bruce [1999] 'State and Nation in Mazzini’s Political Thought', History of

Political Thought, 20:2, 313-336.

Harbold, William, H. [1969] "Justice in the Thought of Pierre-Joseph Proudhon."

Western Political Quarterly, 22:4, 723-741.

Haubtmann, Pierre [1980] La Philosophie Sociale de P.-J. Proudhon, Grenoble, Presses

Universitaires de Grenoble.

--- [1988a] Pierre-Joseph Proudhon: Sa Vie et sa Pensée, 1809-1849, Paris, Relie.

--- [1988b] Pierre-Joseph Proudhon: Sa Vie et sa Pensée, 1849-1865, Paris, Relié.

Hauser, Marc [2006] Moral Minds: How Nature Designed Our Universal Sense of Right and Wrong, New York, Harper Collins.

Hayward, Jack (2005) 'Book Review: Testing the Limits of French Statism’, European Journal of Political Theory, 4:3, 310-307. 
Hazareesingh, Sudhir [1994] Political Traditions in Modern France Oxford, Oxford University Press.

Held, David [1984] 'Beyond Liberalism and Marxism?’ in McLennan, G, Held, D. \& Hall, Stuart (Eds.) The Idea of the Modern State, Milton Keynes, Open University Press.

--- [1995] Democracy and the Global Order: From the Modern State to Cosmopolitan Governance, Cambridge, Polity.

Hennessy, C. A. M. [1962] The Federal Republic in Spain: Pi y Margall and the Federal Republican Movement, 1868-74, Oxford, Clarendon Press.

Hippler, Thomas [2007] Citizens, Soldiers and National Armies: Military Service in France and Germany, 1789-1830, London, Routledge.

Hirst, Paul [1994] Associative Democracy: New Forms of Economic and Social Governance, Cambridge, Polity Press.

Hobsbawm, Eric [1975] The Age of Capital: 1848-1875, London, Abacus.

--- [1994] The Age of Extremes: The Short Twentieth Century 1914-1991, London, Abacus.

Hoffman, Robert L. [1972] Revolutionary Justice: The Social and Political Theory of P.J. Proudhon, London, University of Illinois Press.

Hoffmann, Stanley [1959] 'The Areal Division of Powers in the Writings of French Political Thinkers', in Maas, A (Ed.) Area and Power, Glencoe, University of Illinois Press.

--- [2000] 'An American Social Science: International Relations’ Daedalus 106:3, (1977) 41-60. Reprinted in Linklater, Andrew (Ed) International Relations: Key Concepts in Political Science (Vol. I), London, Routledge, 77-98.

Holden, Gerard [2001] 'The Politer Kingdoms of the Globe: Context and Comparison in the Intellectual History of IR’, Global Society, 15:1, 27-51.

--- [2002] 'Who Contextualises the Contextualisers? Disciplinary History and the Discourse about IR Discourse', Review of International Studies, 28, 253-270. Honig, Jan Willem [1996] 'Totalitarianism and Realism: Hans Morgenathu's German Years’, in Frankel, B. (ed) Roots of Realism, London, Frank Cass, 283-313. 
Howard, Michael [1965] 'Jomini and the Classical Tradition in Military Thought', in Howard, Michael (Ed.) The Theory and Practice of War: Essays Presented to

Captain B. H. Liddell Hart, London, Cassell, 3-20.

--- [1970] Studies in War and Peace, London, Maurice Temple Smith Ltd.

--- [1976] War in European History, Oxford, Oxford University Press.

--- [1978] War and the Liberal Conscience: The George Macaulay Trevelyan Lectures in the University of Cambridge, 1977, London, Temple Smith.

--- [1984] ‘The Military Factor in European Expansion’, in Bull, Hedley \& Watson, Adam (Eds.) The Expansion of International Society, Oxford, Clarendon Press, 33-42.

--- [1970] Studies in War and Peace, London, Maurice Temple Smith Ltd.

--- [2002] Clausewitz: A Very Short Introduction, Oxford, Oxford University Press.

Humphreys, Joshua M. [1999] 'Durkheimian Sociology and 20th-Century Politics: The Case of Célestin Bouglé', History of the Human Sciences, 12:3, 117-138.

Hurrell, Andrew [1990] 'Kant and the Kantian Paradigm in International Relations', Review of International Studies, 16, 183-205.

Ishay, Micheline R.(Ed.) [2007] The Human Rights Reader: Major Politics Essays, Speeches, and Documents from Ancient Times to the Present ( $2^{\text {nd }}$ Ed.), New York, Routledge

Jackson, John Hampden [1957] Marx, Proudhon and European Socialism, London, English Universities Press.

Jenkins, Brian [1990] Nationalism in France: Class and Nation Since 1789, London, Routledge.

Jessop, Bob \& Sum, Ngai-Ling [2001] 'Pre-Disciplinary and Post-Disciplinary

Perspectives', New Political Economy, 6:1, 89-102.

Joll, James [1964] The Anarchists, London, Eyre and Spottiswoode.

Jones, Gareth S. (1996) 'Introduction’, in Fourier, Charles. The Theory of the Four

Movements. Cambridge, Cambridge University Press, vii-xxxii

Jones, H. S. [1998] 'Introduction’, in Jones, H. S. (Ed.) Comte: Early Political Writings, Cambridge, Cambridge University Press, vii-xxviii.

Jørgensen, K. E. (2000) 'Continental IR Theory: The Best Kept Secret’. European Journal of International Relations, 6:1, 9-42. 
Jourdain, Édouard [2006] Proudhon, Dieu et la Guerre: Une Philosophie du Combat, Paris, L’Harmattan.

Kant, Immanuel [1853] Principes Métaphysiques du Droit, Suivis du Project de Paix Perpétuelle, Paris, Librairie Philosophique de Ladrange.

--- [1964] Groundwork of the Metaphysic of Morals, New York, Harper and Row.

--- [1991 a] 'Idea for a Universal History with a Cosmopolitan Purpose', in Reiss, Hans

(Ed.) Kant: Political Writings, $\left(2^{\text {nd }}\right.$ ed.) Cambridge, Cambridge University Press, 41-53.

--- [1991 b] 'Perpetual Peace: A Philosophical Sketch', in Reiss, Hans (Ed.) Kant:

Political Writings, (2 ${ }^{\text {nd }}$ ed.) Cambridge, Cambridge University Press, 93-130.

--- [1991 c] 'The Metaphysics of Morals', in Reiss, Hans (Ed.) Kant: Political Writings.

Oxford, Oxford University Press, 131-175.

--- [1993] Critique of Pure Reason, London, J.M. Dent.

Kanth, Rajani, Kannepalli [1997] Breaking with the Enlightenment: The Twilight of History and the Rediscovery of Utopia, New Jersey, Humanities Press.

Karmis, Dimitrios [2002] 'Pourqoi Lire Proudhon Aujourd'hui? Le Fédéralisme et le Défi de la Solidarité dans les Sociétés Divisées’, Politique et Sociétés, 21:1, 4365.

Kauppi, Mark V. \& Viotti, Paul R. [1992] The Global Philosophers: World Politics in Western Thought, New York, Lexington Books.

Keane, John [1996] Tom Paine: A Political Life, London, Bloomsbury.

Kelly, Michael [1981] 'Hegel in France to 1940: A Bibliographical Essay', Journal of European Studies, 11, 29-52.

Kersting, Wolfgang [1992] 'Politics, Freedom, and Order: Kant's Political Philosophy', in Guyer, Paul (Ed.) The Cambridge Companion to Kant. Cambridge, Cambridge University Press, 342-366.

Kinna, Ruth [1995] 'Kropotkin’s Theory of Mutual Aid in Historical Context', International Review of Social History, 40, 259-283.

--- [2005] Anarchism: A Beginners Guide, Oxford, Oneworld Publications. Knowles, Rob [2004] Political Economy from Below: Economic Thought in Communitarian Anarchism, 1840-1914, New York, Routledge. 
--- [2006] 'Anarchist Notions of Nationalism and Patriotism',

http://raforum.info/article.php3?id_article=2221 Accessed 25/09/07

Koch, Andrew M. [1993] 'Poststructuralism and the Epistemological Basis of

Anarchism', Philosophy of the Social Sciences, 23:3, 327-351.

Kofman, Sarah \& Dukats, Mara [1989] ‘Rousseau’s Phalocratic Ends’, Hypatia, 3:3, 123136.

Körner, S [1955] Kant, Harmondsworth, Penguin.

Kropotkin, Peter [1989] Mutual Aid: A Factor of Evolution, Montreal, Black Rose Books.

--- [1987] The State: Its Historic Role, London, Freedom.

Krug, E. G., Mercy, J. A., Dahlberg, L. L. \& Zmi, A. B. [2002] 'The World Report on Violence and Health', Lancet, 360, 1083-1088.

Kuhn, Thomas S. [1996] The Structure of Scientific Revolutions, Chicago and London, University of Chicago Press.

Kurki, Milja [2006] 'Causes of a Divided Discipline: Rethinking the Concept of Cause in IR', Review of International Studies, 32, 189-216.

Lamb, Peter [1999]. 'Harold Laski: Political Theorist of a World in Crisis', Review of International Studies, 25, 329-342.

Laslett, Peter [1988] 'Introduction', in Laslett, Peter (Ed.) John Locke: Two Treatises of Government, Cambridge, Cambridge University Press, 3-126.

Laski, Harold [1947] Liberty in the Modern State, London, George Allen and Unwin.

--- [1919] Authority in the Modern State, New Haven, Yale University Press.

Lazare, Bernard [1982] L'Antisémitisme: Son Histoire et ses Causes, Paris, Éditions de la Différence.

Le Bras-Chopard, Armelle [1986] De l'Égalité dans la Différence: Le Socialisme de Pierre Leroux, Paris, Presses de la Fondation Nationale des Sciences Politiques.

Levy, Carl [2004] 'Anarchism, Internationalism and Nationalism in Europe, 1860-1939', Australian Journal of Politics and History, 50:3, 330-342.

--- [2007] ' 'Sovversivisimo’: The Radical Political Culture of Otherness in Liberal Italy', Journal of Political Ideologies, 12:2, 147-161.

Linklater, Andrew [1981] 'Men and Citizens in International Relations', Review of International Studies, 7, 23-51. 
--- [1990] Beyond Realism and Marxism: Critical Theory and International Relations, Houndmills, Macmillan.

--- [1996] 'The Achievements of Critical Theory’, in Booth, K, Smith, S \& Zalewski, M (Eds.) International Theory: Positivism and Beyond, Cambridge, Cambridge University Press, 279-297.

--- [1998a] The Transformation of Political Community: Ethical Foundations of a PostWestphalian Era, Cambridge, Polity.

--- [1998b] 'Citizenship and Sovereignty in the Post-Westphalian European State', in

Archibugi, D, Held, D \& Köhler, M (Eds.) Re-Imagining Political Community:

Studies in Cosmopolitan Democracy, Cambridge, Polity, 113-137

--- [2004] 'Norbert Elias, the 'Civilizing Process' and the Sociology of International

Relations', International Politics, 41, 3-35.

Little, Richard [1996] 'The Growing Relevance of Pluralism?' in Booth, K, Smith, S \& Zalewski, M (Eds.) International Theory: Positivism and Beyond, Cambridge, Cambridge University Press, 66-86.

--- [1999] 'Historiography and International Relations’ Review of International Studies, 25, 291-299.

Lobère, Leo A [1961] Louis Blanc: His Life and His Contribution to the Rise of French Jacobin-Socialism, Northwestern University Press.

Long, David, and Wilson, Peter (eds) [1995] Thinkers of the Twenty Year' Crisis: InterWar Idealism Reassessed, Oxford: Clarendon Press.

Lorenz, Konrad [1996] On Aggression, London, Routledge.

Magraw, Roger [1983] France 1815-1914: The Bourgeois Century, Oxford, Fontana.

--- [1992] A History of the French Working Class: Volume 1: The Age of Artisan Revolution, 1815-1871, Oxford, Blackwell Publishers.

Mann, Michael [1988] States, War and Capitalism: Studies in Political Sociology, Oxford, Basil Blackwell.

Manuel, Frank E. [1965] The Prophets of Paris: Turgot, Condorcet, Saint-Simon, Fourier, Comte, New York, Harper and Row.

Marks, Gary, Hooghe, Lisebet \& Blank, Kermit [1996] 'European Integration from the 1980s: State-Centric v. Multi-Level Governance', Journal of Common Market Studies, 34:3, 341-374. 
Marshall, Peter H. [1992] Demanding the Impossible: A History of Anarchism, London, Fontana.

Marshall, T. H. \& Bottomore, Tom [1992] Citizenship and Social Class, London, Pluto. Marx, Karl. [1977] ‘On the Jewish Question’ In Karl Marx: Selected Writings, edited by David McLellan, Oxford, Oxford University Press, 39-62.

Mason, Pamela A. [1993] 'The Communion of Citizens: Calvinist Themes in Rousseau's Theory of the State', Polity, 26:1, 25-49.

Maude, Aylmer [1908] The Life of Tolstoy: First Fifty Years, London, Constable.

May, Christopher [2000] A Global Political Economy of Intellectual Property Rights:

The New Enclosures?, London, Routledge.

May, Todd [1994] The Political Philosophy of Poststructuralist Anarchism,

Pennsylvania, Pennsylvania State University Press.

McLellan, David [1977] Karl Marx: Selected Writings, Oxford, Oxford University Press.

McNeill, William H. [1983] The Pursuit of Power: Technology, Armed Force, and Society Since A.D. 1000, Oxford, Basil Blackwell.

Mendus, Susan [1992] 'Kant: An Honest but Narrow-Minded Bourgeois’?’ in Williams, Howard (Ed.) Essays on Kant's Political Philosophy, Cardiff, University of Wales Press, 166-190.

Menuelle, Thierry [1993] Marx, Lecteur de Proudhon, Paris, Presses E.H.E.S.S.

Mill, John Stuart [1848] Correspondence to Harriet Taylor Mill. The Online Library of Liberty, A Project of Liberty Fund, Inc.

http://oll.libertyfund.org/index.php?option=com staticxt\&staticfile=show.php\&tit

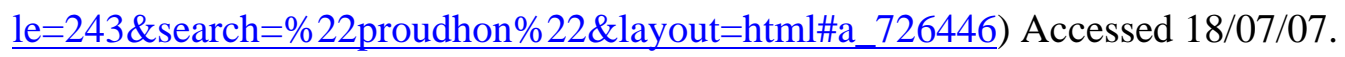
--- [1993] ‘On Liberty’, in Williams, Geraint (Ed.) John Stuart Mill: Utilitarianism, on Liberty, Considerations on Representative Government, Remarks on Bentham's Philosophy, London, J. M. Dent, 69-187.

Miller, David [1999] 'Bounded Citizenship’, in Hutchings, K. \& Dannreuther, R. (Eds.)

Cosmopolitan Citizenship, London, Macmillan, 60-79.

Mills, C. W. (1999) The Sociological Imagination, Oxford, Oxford University Press.

Milner, Helen [1991] 'The Assumption of Anarchy in International Relations Theory: A Critique', Review of International Studies, 17, 67-85.

Milward, Alan S., [1992] The European Rescue of the Nation-State, London, Routledge. 
Mitrany, David [1951] Marx against the Peasant: A Study in Social Dogmatism, London,

Weidenfeld and Nicolson.

--- [1975] The Functional Theory of Politics, London, Martin Robertson

Mitzman, Arthur [1996] 'Michelet and Social Romanticism: Religion, Revolution,

Nature' Journal of the History of Ideas, 57, 659-682.

Marc, Alexander [1979] 'New and Old Federalism: Faithful to the Origins', Publius, 9:4, 117-130.

Marx, K. (1977) ‘On the Jewish Question’, in McLellan D. (Ed.) Karl Marx: Selected Writings. Oxford, Oxford University Press, 39-62.

Moissonnier, Maurice [1995] 'Premièr Partie: Des Origines à 1871', in Willard, Claude (Ed.) La France Ouvrière: Tome I, Des Origines à 1920, Paris, Les Éditions de l’Atelier/Les Éditions Ouvrières.

Montesquieu [1989] The Spirit of the Laws, Cambridge, Cambridge University Press.

Morgenthau, Hans J. [1946] Scientific Man Versus Power Politics, Chicago, University of Chicago Press.

--- [1962] 'The Corruption of Liberal Thought: Harold Laski', in Morgenthau, H. J. (Ed.)

The Restoration of American Politics, Chicago, University of Chicago Press, 2935.

--- [1993] Politics among Nations: The Struggle for Power and Peace (Brief ed.), New York, McGraw-Hill.

Morland, David [1997] Demanding the Impossible? Human Nature and Politics in Nineteenth-Century Social Anarchism, London, Cassell.

Moses, Claire Goldberg [1984] French Feminism in the Nineteenth Century, Albany, State University of New York Press.

Mosse, George L. [1978] Toward the Final Solution: A History of European Racism, London, J. M. Dent.

Mouffe, Chantal (Ed.) [1992] Dimensions of Radical Democracy: Pluralism, Citizenship, Community, London, Verso.

Moysset, Hervé [1982] 'Introduction’ in Pierre-Joseph Proudhon, La Guerre et la Paix, Rechercehs sur la principe et la constitution du droit des gens, Nouvelle édition publiée avec des notes et des documents inédits sous la direction de C. Bouglé et H. Moysset (Reprint of Marcel Rivière edition) Geneva, Slatkine, i-xciv. 
Mueller, John [1990] Retreat from Doomsday: The Obsolescence of Major War, London, Basic Books.

Murphy, Craig. N. (2007) 'The Promise of Critical IR, Partially Kept', Review of International Studies, 33, 117-133.

Nelson, Ralph [1975] 'The Federal Principle in French Political Thought', Publius, 5:3, 7-62

Newman, Saul [2001] From Bakunin to Lacan: Anti-Authoritarianism and the Dislocation of Power, London, Lexington.

Nguyen, Victor [1991] Aux Origines de l'Action Française : Intelligence et Politique Vers 1900, Paris, Fayard.

Nicholson, Harold [1946] The Congress of Vienna: A Study in Allied Unity: 1812-1822, London, Constable.

Nicolet, Claude [1982] L'Idée Républicaine en France (1789-1924): Essai d'Histoire Critique, Paris, Gallimard.

Noland, Aaron [1967] 'Pierre-Joseph Proudhon - Socialist as Social Scientist', American Journal of Economics and Sociology, 26, 313-328.

--- [1967] 'Proudhon and Rousseau', Journal of the History of Ideas, 28:1, 33-54.

--- [1968] 'History and Humanity: The Proudhonian Vision', in White, Hayden (Ed.) The Uses of History: Essays in Intellectual and Social History, Detroit, Wayne State University Press, 59-105.

--- [1970] 'Proudhon's Sociology of War', The American Journal of Economics and Sociology, 29:3, 289-304.

Nozick, Robert [1974] Anarchy, State and Utopia, Oxford, Basil Blackwell.

O’Neill, Onora [2000] 'Bounded and Cosmopolitan Justice’, Review of International Studies, 26, 45-60.

Paret, Peter [1986] 'Clausewitz', in Paret, Peter (Ed.) Makers of Modern Strategy from

Machiavelli to the Nuclear Age, Oxford, Clarendon, 186-213.

--- [1986] 'Napoleon and the Revolution in War', in Paret, Peter (Ed.) Makers of Modern

Strategy from Machiavelli to the Nuclear Age, Oxford, Clarendon Press, 123-142. Parkinson, F [1977] The Philosophy of International Relations, London, Sage. 
Parry, Geraint [2001] 'Émile: Learning to Be Men, Women, and Citizens’, The Cambridge Companion to Rousseau, Cambridge, Cambridge University Press, 247-271.

Patomäki, H. \& Wight, C. (2000) 'After Post-Positivism?: The Promises of Critical Realism’, International Studies Quarterly, 44, 213-237.

Pedersen, Jean Elisabeth [2001] 'Sexual Politics in Comte and Durkheim: Feminism, History, and the French Sociological Tradition', Signs: Journal of Women in Culture and Society, 27:1, 229-263.

Pflanze, Otto. (1966) 'Nationalism in Europe, 1848-1871’ The Review of Politics, 28, 129-143.

Pick, Daniel [1993] War Machine: The Rationalization of Slaughter in the Modern Age, New Haven, Yale University Press.

Pickering, Mary [1993] August Comte: An Intellectual Biography, Vol. I, Cambridge, Cambridge University Press.

Pilbeam, Pamela [2000] French Socialists before Marx: Workers, Women and the Social Question, Teddington, Acumen Press.

Pilbeam, Pamela M. [1995] Republicanism in Nineteenth-Century France, 1814-1871, London.

Pizarro, David [2000] 'Nothing More Than Feelings? The Role of Emotions in Moral Judgement', Journal for Social Behaviour, 30:4, 355-375.

Plamenatz, John [1952] The Revolutionary Movement in France: 1815-71, London, Longmans.

Pocock, J. G. A. [1985] 'The Mobility of Property and the Rise of Eighteenth Century Sociology’, in Pocock, J. G. A (Ed.) Virtue Commerce and History: Essays in Political Thought and History, Chiefly in the Eighteenth Century, Cambridge, Cambridge University Press, 103-124.

--- [1995] 'The Ideal of Citizenship since Classical Times’, in Beiner, Roland (Ed.) Theorising Citizenship. New York, State University of New York Press, 29-52. Polanyi, Karl [2001] The Great Transformation: The Political and Economic Origins of Our Time, Boston, MA, Beacon Press.

Popper, Karl [1986] The Poverty of Historicism, London, Routledge and Keegan Paul. 
Porter, Brian [2000] 'E. H. Carr - the Aberystwyth Years, 1936-47', in Cox, Michael

(Ed.) E. H. Carr: A Critical Appraisal. Basingstoke, Palgrave Macmillan, 36-67.

Porter, Bruce. D [1994] War and the Rise of the State: The Military Foundations of

Modern Politics, New York, Free Press.

Price, Roger [1987] A Social History of Nineteenth-Century France, London,

Hutchinson.

--- [1993] A Concise History of France, Cambridge, Cambridge University Press.

--- [2002] 'Louis-Napoleon Bonaparte: ‘Hero’ or ‘Grotesque Mediocrity’?’ in Cowling,

Mark \& Martin, James (Eds.) Marx’s Eighteenth Brumaire: (Post)Modern

Interpretations. London, Pluto Press, 145-161.

Prichard, Alex [2007] 'Justice, Order and Anarchy: The International Political Theory of Pierre-Joseph Proudhon (1809-1865)', Millennium: Journal of International Studies, 35:3, 623-645.

Primi, Alice [2006] 'Women’s History According to Jenny P. d’Héricourt (1809-1875),

‘Daughter of Her Century’, Gender \& History, 18:1, 150-159.

Proudhon, Pierre-Joseph, [1861] Theorie de l'Impot, Paris, E. Dentu

--- [c.1863] La Pologne, Considérations sur la Vie et la Mort des Nationalités,

Unpublished Manuscript, Besancon Municipal Library.

--- [1865] Nouvelles Observations sur l'Unité Italienne, Paris, E. Dentu.

--- [1867a] Du Principe Fédératif et de la Nécessité de Reconstituer le Parti de la

Révolution, (inc.) [1867b] Si Les Traités de 1815 ont Cessé d'Exister, Paris,

Ernest Flammarion.

--- [1868] France et Rhin, Paris, A. Lacroix, Verboeckhoven et Companie.

--- [1939] La Pornocratie ou les femmes dans les temps modernes, Oeuvres Complètes de

P.-J. Proudhon, Vol. XI. Paris, Marcel Riviere.

--- [1972] System of Economical Contradictions, or, the Philosophy of Misery,

(Translated by Benjamin Tucker) New York, Arno Press.

--- [1979] The Principle of Federation and the Need to Reconstitute the Party of the

Revolution, (Translated by Richard Vernon) Toronto, University of Toronto Press.

--- [1982] De la Capacité Politique des Classes Oeuvrières, Oeuvres Complètes de P.-J.

Proudhon, Vol. III, Paris, Slatkine. 
--- [1988/1990] De La Justice dans La Révolution et dans l'Eglise: Études de Philosophie Pratique, (IV Vols - a, b, c, d.) Paris, Fayard.

--- [1989] General Idea of the Revolution in the Nineteenth Century, (Translated by

Robert Graham), London, Pluto Press.

--- [1994] What Is Property? Or, an Inquiry into the Principle of Right and of

Government, (Translated by D. R. Kelly and B. Smith), Cambridge, Cambridge

University Press.

--- [1998] La Guerre et la Paix, Recherches sur la Principe et la Constitution du Droit des Gens, Paris, Editions Tops.

--- [1999] Notes Sur La Guerre Et La Paix: A Rapprocher de l'Ouvrage la Guerre et la

Paix, Antony, France, Edition Tops/ H. Triniquer.

--- [2004] P-J Proudhon: Carnets, Dijon, Les Presses du Réel.

--- [unpublished] [2007] 'Notes on Kant for composition of La Guerre et la Paix' Stored in the Bibliotèque d'Étude et de Conservation, Besançon, France. (MS. Z550 and MS. 2859) Transcribed by Edward Castleton

Puchala, Donald J. [1998] 'Fidling with Concepts While the World Burned. Review of the Political Discourse of Anarchy: A Disciplinary History of International Relations by Brian C. Schmidt’ Mershon International Studies Review 42, 330332.

Puech, Jules L. [1920] 'Proudhon et la Guerre’, in Bouglé, Célestin Charles Alfred (Ed.) Proudhon et Notre Temps. second ed. Paris, Editions \& Librairie, 203-238.

Rees, Ioan Bowen [1993] 'Ffedraliaeth Proudhon Ac Ewrop Heddiw', in Rees, Ioan Bowen (Ed.) Cymuned a Chenedl: Ysgrifau Ar Ymreolaeth. Llandysul, Gomer, 145-183.

Rengger, Nicholas and Thirkell-White, Ben (eds) [2007] 'Special Issue: Critical International Relations Theory after 25 years’ Review of International Studies, 33

Rich, Norman [1970] The Age of Nationalism and Reform: 1850-1890, London, Weinfeld and Nicholson.

Ritter, Alan [1969] The Political Thought of Pierre-Joseph Proudhon, Princeton, Princeton University Press.

--- [1975] 'Goodwin, Proudhon and the Anarchist Justification of Punishment', Political Theory, 3:1, 69-87. 
Riviale, Philippe [2003] Proudhon: La Justice, Contre le Souverain. Tentative d'Examen d'une Théorie de la Justice Fondée sur l'Équilibre Économique, Paris, L'Harmattan.

Rocker, Rudolf [1998] Nationalism and Culture, (Translated by Ray Chase) Montreal, Black Rose Books.

Rolland, Patrice [1993] 'La Fédéralisme, Un Concept Social Global Chez Proudhon', Revue du Droit Public, Nov, 1521-1546.

Rosanvallon, Pierre [1990] L'État en France de 1789 a nos Jours, Paris, Seuil.

Rosenberg, Justin [1994] The Empire of Civil Society: A Critique of the Realist Theory of International Relations, London, Verso.

Rousseau, Jean-Jacques [1997a] 'The State of War', in Gourevitch, Victor (Ed.)

Rousseau: The Social Contract and Other Later Political Writings, Cambridge Cambridge University Press, 162-176.

--- [1997b] 'Considerations on the Government of Poland', in Gouervitch, Victor (Ed.)

Rousseau: The Social Contract and Other Later Political Writings, Cambridge, Cambridge University Press, 177-260.

--- [1997c] 'Of the Social Contract or Principles of Political Right', in Gourevitch, Victor

(Ed.) Rousseau: The Social Contract and Other Later Political Writings,

Cambridge, Cambridge University Press, 39-152.

--- [1997d] 'Discourse on Political Economy', in Gourevitch, Victor (Ed.) Rousseau: The Social Contract and Other Later Political Writings, Cambridge, Cambridge University Press, 3-38.

--- [1997e] 'Letter to Voltaire', in Gouervitch, Victor (Ed.) Rousseau: The Discourses and Other Early Political Writings, Cambridge, Cambridge University Press, 232246.

--- [1997f] 'Discourse on the Origin and Foundations of Inequality Among Men or Second Discourse' in Gourevitch, Victor (Ed.) Rousseau: The Discourses and Other Political Writings, Cambridge, Cambridge University Press, 111-222 --- [2002] 'From Abstract and Judgment of Saint-Pierre's Project for Perpetual Peace', in Brown, Chris, Nardin, Terry \& Rengger, Nicholas (Eds.) International Relations in Political Thought: Texts from the Ancient Greeks to the First World War, Cambridge, Cambridge University Press, 425-427. 
Runciman, David [2001] 'History of Political Thought: The State of the Discipline', British Journal of Politics and International Relations, 3:1, 84-104.

Ruyssen, T. H. [1946] 'Introduction’ in Proudhon, P.-J. Philosophie du Progrès, Oeuvres Completes, Paris, Marcel Rivière.

Rzhevsky, Nicholas [1975] 'The Shape of Chaos: Herzen and War and Peace', Russian Review, 34:3, 367-381.

Sampson, Ronald Victor [1973] Tolstoy, the Discovery of Peace, London, Heinemann. Sayer, R. A. [2005] The Moral Significance of Class, Cambridge, Cambridge University Press.

Schapiro, J. Salwyn [1945] 'Pierre-Joseph Proudhon, Harbinger of Fascism', The American Historical Review, 50:4, 714-737.

Scheuerman, William E. [1999] Carl Schmitt: The End of Law, Oxford Rowman and Littlefield.

Scharff, Robert C. [1995] Comte After Positivism, Cambridge, Cambridge University Press.

Schmidt, Brian C. [1998] The Political Discourse of Anarchy: A Disciplinary History of International Relations, New York, State University of New York Press.

--- [2002] 'On the History and Historiography of International Relations'. In Carlsnaes, W., Risse, T. \& Simmons, B. A. (Eds.) Handbook of International Relations, London, Sage, 3-22

Schmitt, Carl [1985] Political Theology: Four Chapters on the Concept of Sovereignty, Cambridge Mass., MIT Press.

--- [1999] 'Ethic of State and Pluralistic State'. In Mouffe, C. (Ed.) The Challenge of Carl Schmitt, London, Verso, 195-208

Schroeder, Paul W. [1994] The Transformation of European Politics 1763-1848, Oxford, Oxford University Press.

Scruton, Roger [1982] Kant, Oxford, Oxford University Press.

Segalen, Martine [1983] Love and Power in the Peasant Family: Rural France in the Nineteenth Century, Oxford, Basil Blackwell.

Shaw, Martin [1987] Dialectics of War: An Essay in the Social Theory of Total War and Peace, London, Pluto Press. 
Shaw, Martin \& Creighton, Colin [1987] 'Introduction', in Creighton, Colin \& Shaw, Martin (Eds.) The Sociology of War and Peace. 24 ed. London, Macmillan, 1-16.

Sheehan, Michael [1999] 'Community, Anarchy and Critical Security’. Conference paper presented at 'Redefining Security’, ECPR Joint Session Workshop. Manheim.

Shy, John [1986] 'Jomini', in Paret, Peter (Ed.) Makers of Modern Strategy from Machiavelli to the Nuclear Age, Oxford, Clarendon Press, 143-185.

Silberner, Edmund [1946] 'Charles Fourier on the Jewish Question', Jewish Social Studies, 8, 245-266.

--- [1948] 'Proudhon’s Judeophobia', Historia Judaica, 10, 61-80.

Simon, Yves [1987] ‘A Note on Proudhon’s Federalism’, in Elazar, Daniel J. (Ed.)

Federalism as Grand Design: Political Philosophers and the Federal Principle, Lanham, University Press of America, 223-234.

Skinner, Quentin [1988] 'Meaning and Understanding in the History of Ideas (1969)', in Tully, James (Ed.) Meaning and Context: Quentin Skinner and His Critics, Cambridge, Polity, 29-67.

--- [1996] Reason and Rhetoric in the Philosophy of Hobbes, Cambridge, Cambridge University Press.

Skocpol, Theda [1979] States and Social Revolutions: A Comparative Analysis of France, Russia, and China, Cambridge, Cambridge University Press.

Smith, Denis Mack [1959] Italy: A Modern History, Ann Arbor, University Of Michigan Press.

Smith, Rupert [2005] The Utility of Force: The Art of War in the Modern World, London, Allen Lane.

Smith, Steve [1995] 'The Self-Images of a Discipline: A Genealogy of International Relations', in Smith, Steve \& Booth, Ken (Eds.) International Relations Theory Today, Cambridge, Polity Press, 1-37.

--- [1997] 'Power and truth: a reply to William Wallace', Review of International Studies, 23: 507-516.

--- [2004] 'Singing Our World into Existence: International Relations Theory and September 11' (Presidential Address to the International Studies Association, February 27, 2003, Portland. Or.) International Studies Quarterly, 48:3, 499-515. 
Solomon, Robert [1993] The Passions: Emotions and the Meaning of Life, Indianapolis, Hackett.

Stauffer, Thomas, Töpperwien, Nicole \& Thalmann-Torres, Urs [2002] 'Switzerland', in Griffiths, Ann L. (Ed.) Handbook of Federal Counties, 2002. Montreal \& Kingston, McGill-Queen’s University Press, 314-328.

Talmon, J. L. [1952] The Origins of Totalitarian Democracy, London, Secker and Warburg.

--- [1960] Political Messianism: The Romantic Phase, London, Secker and Warburg. Taylor, A. J. P. [1954] The Struggle for Mastery in Europe: 1848-1918, Oxford, Clarendon Press.

--- [1995a] 'Napoleon' in Wigley, Chris (ed) A.J.P Taylor: From Napoleon to the Second International, Essays on Nineteenth-Century Europe. London, Penguin Books, 68-80.

--- [1995b] '1848' in Wigley, Chris (ed) A.J.P Taylor: From Napoleon to the Second International, Essays on Nineteenth-Century Europe. London, Penguin Books, 148-172.

Taylor, Keith (Ed.) [1975] Henri Saint-Simon (1760-1825): Selected Writings on Science, Industry and Social Organisation, London, Croom Helm.

Teschke, Benno [1998] 'Geopolitical Relations in the European Middle Ages: History and Theory’, International Organisation, 52:2, 325-358.

--- [2002] 'Theorising the Westphalian System of States: International Relations from Absolutism to Capitalism', European Journal of International Relations, 8:1, 548.

--- [2003] The Myth of 1648: Class, Geopolitics, and the Making of Modern International Relations, London: Verso.

Thomas, Paul [1980] Karl Marx and the Anarchists, London, Routledge.

Tilly, Charles [1985] 'War Making and State Making as Organised Crime’, in Evans, Peter B., Rueschemeyer, Dietrich \& Skocpol, Theda (Eds.) Bringing the State Back In. Cambridge, Cambridge University Press, 169-191.

Tolstoy, Leo [1998] War and Peace, Oxford, Oxford University Press. Townsend, Jules (2007) 'Living with Capitalism: From Hobson to Giddens’. British Journal of Politics and International Relations, 9:4, 599-617. 
Trinquier, Hervé [1998] 'Introduction’, in Proudhon, Pierre-Joseph, La Guerre et la Paix, Recherches sur la Principe et la Constitution du Droit des Gens, Paris, Editions Tops, 7-15.

Tuck, Richard [2001] The Rights of War and Peace: Political Thought and the International Order from Grotius to Kant, Oxford, Oxford University Press.

Tully, James (Ed.) [1988] Meaning and Context: Quentin Skinner and His Critics, Cambridge, Cambridge University Press.

Turner, Brian [1986] Citizenship and Capitalism: The Debate over Reformism, London, Allen and Unwin.

Turner, Scott [1998] 'Global Civil Society, Anarchy and Governance: Assessing an Emerging Paradigm', Journal of Peace Research, 35:1, 25-42.

Unger, Roberto Mangabeira [1987a] False Necessity: Anti-Necessitarian Social Theory in the Service of Radical Democracy, Cambridge, Cambridge University Press.

--- [1987b] Plasticity into Power: Comparative-Historical Studies on the Institutional Conditions of Economic and Military Success, Cambridge, Cambridge University Press.

--- [1987c] Social Theory : Its Situation and its Task : A Critical Introduction to Politics, a Work in Constructive Social Theory, Cambridge, Cambridge University Press.

Vasquez, J. A. (1998) The Power of Power Politics: From Classical Realism to Neotraditionalism, Cambridge, Cambridge University Press.

Vernon, Richard [1979] 'Introduction', in Proudhon, P-J, The Principle of Federation or the Need to Reconstitute the Part of the Revolution. Toronto, University of Toronto Press, xi-xlvii.

--- [1986] Citizenship and Order: Studies in French Political Thought, Toronto, University of Toronto Press.

Vincent, K. Steven [1984] Pierre-Joseph Proudhon and the Rise of French Republican Socialism, Oxford, Oxford University Press.

--- [1992] Between Marxism and Anarchism: Benoît Malon and French Reformist Socialism, Berkley, University of California Press.

--- [1997] 'Review of John Ehrenberg's Proudhon and His Age', American Historical Review, 102:4, 1173-1174.

Voyenne, Bernard, [1973] Le Fédéralisme de P. J. Proudhon, Paris, Presses d’Europe. 
Walker, R.B.J. [1993] Inside/Outside: International Relations as Political Theory, Cambridge, Cambridge University Press.

Walsh, W. H. [1975] Kant's Criticism of Metaphysics, Edinburgh, Edinburgh University Press.

Walzer, Michael [1980] 'The Moral Standing of States: A Response to Four Critics’, Philosophy and Public Affairs, 9:3, 209-229.

--- [1992a] 'The Civil Society Argument', in Mouffe, Chantal (Ed.) Dimensions of Radical Democracy: Pluralism, Citizenship, Community, London, Verso, 89-107. --- [1992b] Just and Unjust Wars: A Moral Argument with Historical Illustrations, London, Basic Books.

Watkins, Frederick M. [1947] 'Proudhon and the Theory of Modern Liberalism', The Canadian Journal of Economics and Political Science, 13:3, 429-435.

Watson, D. J. [1983] Power, Providence and Antagonism in Pierre-Joseph Proudhon's 'La Guerre et la Paix’. MSc Dissertation, Department of Politics, Bristol University.

Weber, Eugen [1962] 'The Prophets of Paris (Review)', The American Historical Review, 67:4, 1027-1029.

Weill, Claudie [2004] 'Les Internationales et la Question Nationale’, in Becker, JeanJaques \& Candar, Gilles (Eds.) Histoire des Gauches en France: Volume 1, L’Héritage Du XIXe Siècle. Paris, La Découverte, 491-505.

Weiss, Thomas G. [1975] 'The Tradition of Philosophical Anarchism and Future Directions in World Policy', Journal of Peace Research, 12, 1-17.

Weitz, Mark [1972] 'Introduction' in Proudhon, Pierre-Joseph La Guerre et la Paix, Principe et la Constitution des droits des gens, New York, Garland Publishers, 526.

Wendt, Alexander [1992] 'Anarchy Is What States Make of It: The Social Construction of Power Politics’, International Organization, 46:2, 391-425.

--- [1999] Social Theory of International Relations, Cambridge, Cambridge University Press.

--- [2003] ‘Why a World State is Inevitable’, European Journal of International Relations, 9:4, 491-542. 
Wheeler, Nicholas J. [2004] 'The Kosovo Bombing Campaign', in Reus-Smit, Christian (Ed.) The Politics of International Law, Cambridge, Cambridge University Press, 189-216.

White, Hayden [1973] Metahistory: The Historical Imagination in Nineteenth-Century Europe, Baltimore, Johns Hopkins University Press.

Wight, Colin [2002] 'Philosophy of Social Science and International Relations', in Carlsnaes, Walter, Risse, Thomas \& Simmons, Beth A (Eds.) Handbook of International Relations, London, Sage, 23-51.

--- [2006] Agents, Structures and International Relations: Politics as Ontology, Cambridge, Cambridge University Press.

Wight, Martin [1966] 'Why is there no International Theory?', in Butterfield, Herbert \& Wight, Martin (Eds.) Diplomatic Investigations: Essays in the Theory of International Politics, London, George Allen and Unwin, 17-34

Wight, Martin, Wight, Gabriele \& Porter, Brian [1991] International Theory: The Three Traditions, Leicester, Leicester University Press for the Royal Institute of International Affairs.

Williams, Christopher R. \& Arrigo, Bruce A. [2001] 'Anarchaos and Order: On the Emergence of Social Justice’, Theoretical Criminology, 5:2, 223-252.

Williams, Howard [1983] Kant's Political Philosophy, Oxford, Basil Blackwell.

--- [1992] International Relations in Political Theory, Milton Keynes, Open University Press.

--- [1996a] International Relations and the Limits of Political Theory, London, Macmillan.

--- [1996b] 'Kant: Theorist Beyond Limits', in Clark, I \& Neumann, I. B. (Eds.) Classical Theories of International Relations, New York, St. Martin's Press, 71-98. Williams, Howard, Wright, Moorhead \& Evans, Tony (Eds.) [1993] A Reader in International Relations and Political Theory, Buckingham, Open University Press.

Williams, Michael C. [1989] 'Rousseau, Reason and Realpolitik', Millennium: Journal of International Studies, 18:2, 185-203.

--- [1992] 'Reason and Realpolitik: Kant’s “Critique of International Politics”', Canadian Journal of Political Science, 25:1, 99-119. 
--- [1996] 'Hobbes and International Relations: A Reconsideration’, International Organisation, 50:2, 213-236.

--- [2004] 'Why Ideas Matter in International Relations: Hans Morgenthau, Classical Realism, and the Moral Construction of Power Politics', International Organization, 58, 633-655.

--- [2005] The Realist Tradition and the Limits of International Relations, Cambridge, Cambridge University Press.

Wilson, A. N. [1988] Tolstoy, London, Hamilton.

Wilson, Peter [1998] 'The Myth of the First Great Debate’ Review of International Studies, 24, 1-16.

Winock, Michel [1998] Nationalism, Anti-Semitism, and Fascism in France, Stanford, Stanford University Press.

Wistrich, Robert S [1995] 'Radical Antisemitism in France and Germany (1840-1880)', Modern Judaism, 15, 109-135.

Wolff, Robert Paul [1998] In Defense of Anarchism, Berkeley, University of California Press.

Wolin, Richard. [1990] 'Carl Schmitt, Political Existentialism and the Total State', Theory and Society, 19, 389-416.

---. [1992] 'Carl Schmitt: The Conservative Revolutionary and the Aesthetics of Horror', Political Theory, 20:3, 424-447.

Wolker, Robert [1995] Rousseau, Oxford, Oxford University Press.

Wood, Allen W [1992] 'Rational Theology, Moral Faith, and Religion', in Guyer, Paul (Ed.) The Cambridge Companion to Kant, Cambridge, Cambridge University Press, 394-416.

Woodcock, George [1956] Pierre-Joseph Proudhon: A Biography, London, Routledge and Keegan Paul.

--- [1972] 'A Plea for the Anti-Nation', Canadian Forum, 16-47.

Wright, Quincy [1942] A Study of War, Chicago, University of Chicago Press.

Wright, Robert [1995] The Moral Animal: Why We Are the Way We Are: The New

Science of Evolutionary Psychology, New York, Vintage Books.

Zeldin, Theodore [1979] France 1848-1945, Oxford, Oxford University Press.

--- [1979] France 1848-1945: Ambition and Love, Oxford, Oxford University Press. 
Zimmer, Oliver [2003] A Contested Nation: History, Memory and Nationalism in Switzerland, 1761-1891, Cambridge, Cambridge University Press.

Zola, Émile [1972] Nana, Harmondsworth, Penguin. 